\title{
COMMUNITY ENTERPRISES: \\ ENDURING INSTITUTIONS FOR A NEWER WORLD
}

By

Bernard Teahan

\author{
A thesis \\ submitted to the Victoria University of Wellington \\ in fulfilment of the \\ requirements for the degree of \\ Doctor of Philosophy \\ in Public Policy
}

Victoria University of Wellington

2006 


\begin{abstract}
Community enterprises have long endured.

Why they have endured and why there are undergoing a renaissance is explained by the very nature of their constituent parts: a sense of self, a love of and the need for community, the pursuit of solidarity, and enterprise attributes. These are the driving forces behind community enterprises, which have melded together to deliver significant benefits to many New Zealand communities over many years. Although community enterprises are not for every enterprise circumstance and every community, they reflect underlying truths of human nature, and when successfully employed, will endear themselves to their communities. When unsuccessful, they may generate strong emotions of rejection.
\end{abstract}

This thesis explores these themes and their relevance to contemporary New Zealand society. It pursues the question of why some communities have a strong affinity for the concept of community enterprises and others do not; and argues for their importance as a complementary structure in a global world rightly and properly dominated by private enterprise. Distinctive features of community 
enterprises, including ownership, the pursuit of mixed economic and social goals, and the influence of politics, are also examined.

Finally, the thesis tells the dynamic story of community enterprises in contemporary New Zealand through eight vignettes and four case studies.

This thesis supports a contention that community enterprises are enduring and endearing institutions that can significantly benefit the well-being of a community. 


\section{TABLE OF CONTENTS}

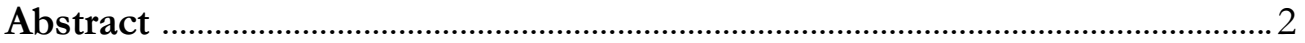

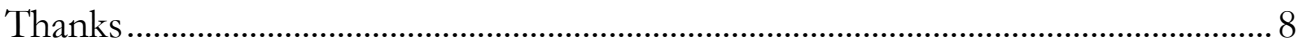

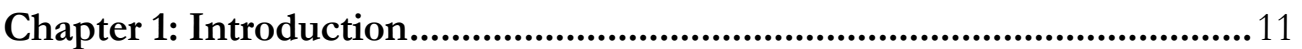

1.1 A Personal Journey ............................................................................................... 14

1.2 The Nature of Community Enterprises ..................................................................16

1.3 The Research Questions and Conclusions ....................................................18

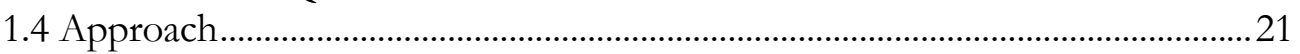

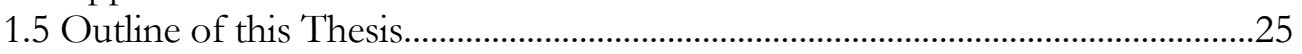

Chapter 2: The Philosophical and Theoretical Bases to Community

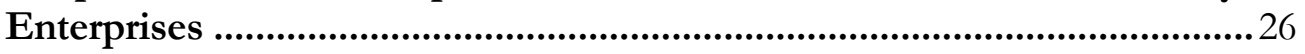

2.1 Setting the Scene for Community Enterprises ......................................................33

2.1.1 Democratic Capitalism: the Road to Success and the Seeds of Conflict.......33

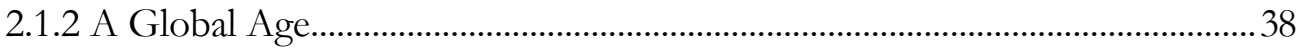

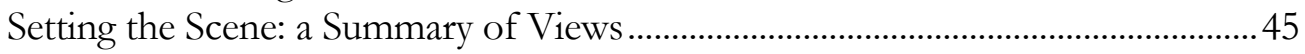

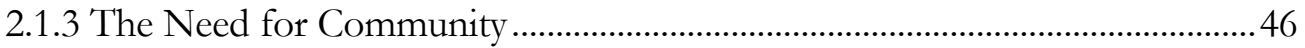

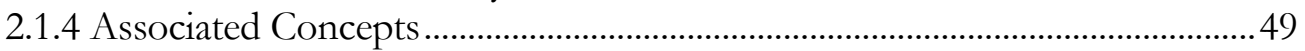

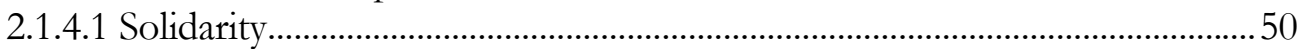

2.1.4.2 Subsidiarity (and the Need for Freedom) ……............................................... 53

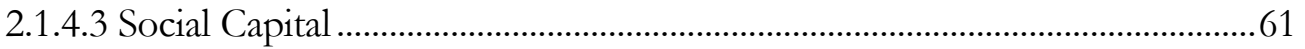

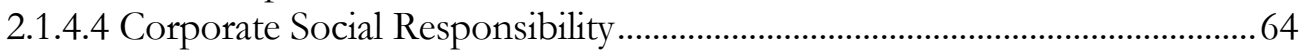

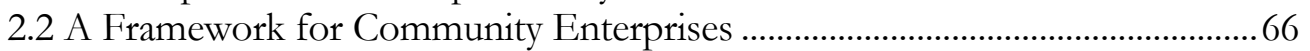

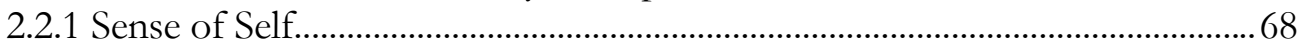

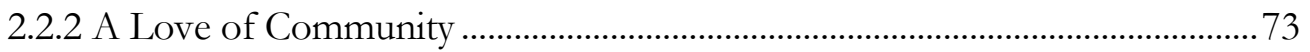

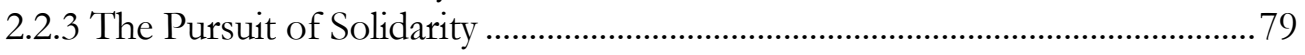

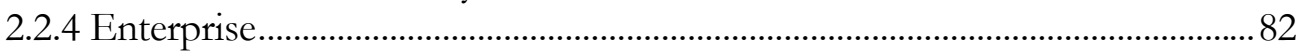

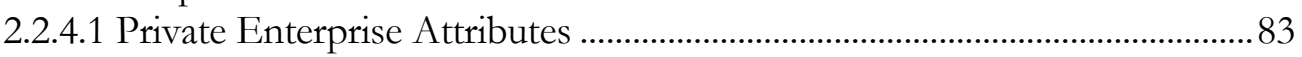

2.2.4.2 Personal Skills: Community Benefits............................................................... 87

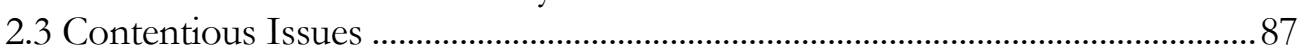

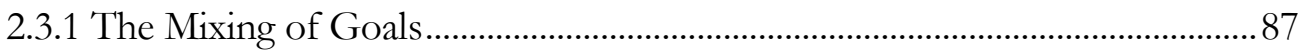

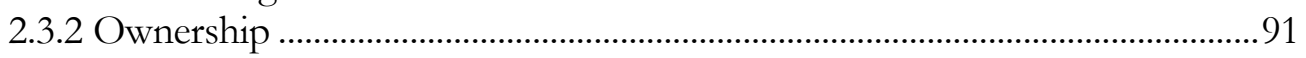

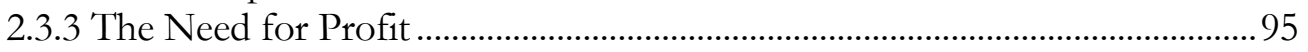

Summary: Pulling the Strands Together ............................................................... 98

Chapter 3: Community Enterprises Worldwide and in New Zealand:

Their Structure, Form and Presence ........................................................... 102

3.1 The Civil and Solidarity-Based Economy ……….........................................102

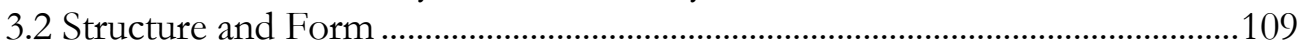

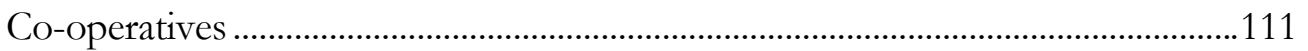

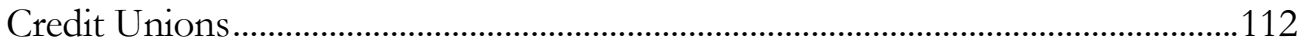

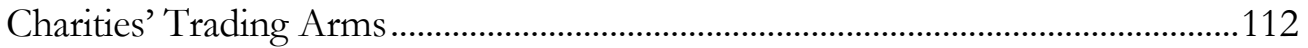

Community Enterprise Companies ..................................................................113 
Community Interest Companies ....................................................................114

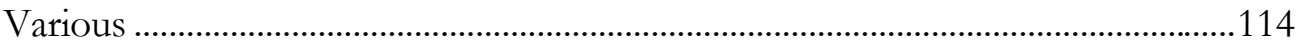

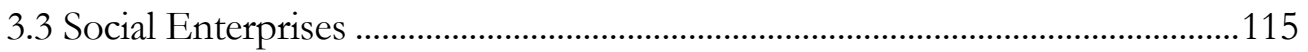

3.4 Community Enterprises in New Zealand ............................................................116

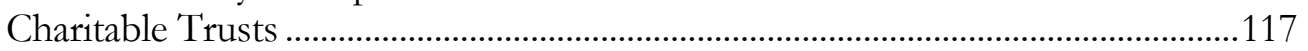

Licensing Trusts....................................................................................................118

Electricity Trusts and Energy Companies ..............................................................119

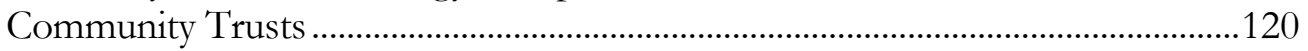

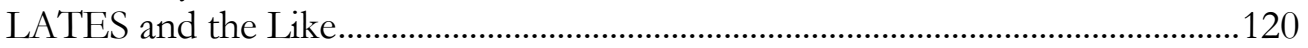

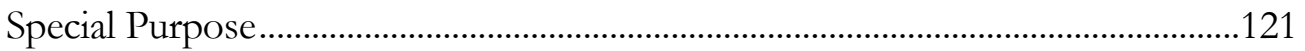

Chapter 4: Methodology ................................................................................. 123

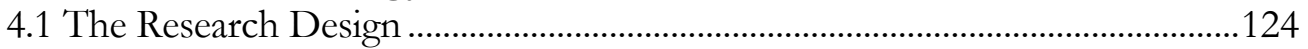

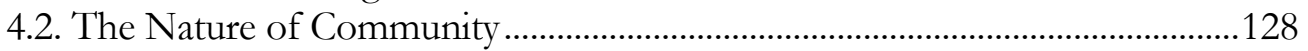

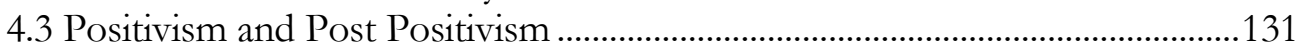

4.3.1 'Thick Description'.....................................................................................138

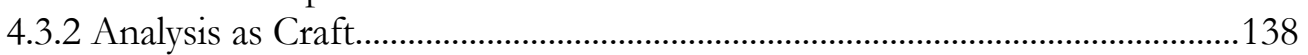

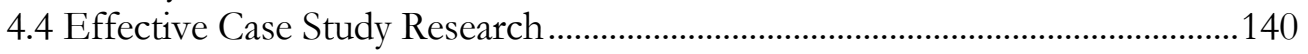

4.4.1 Case Selection - The Process Adopted..........................................................142

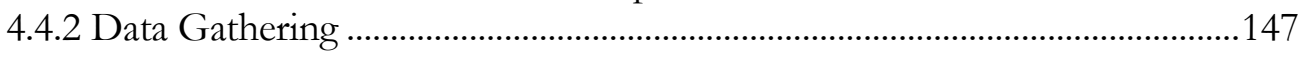

4.4.3 Cross Case Analysis..........................................................................................151

Chapter 5: Eketahuna New Zealand: a Case Study of Small Town

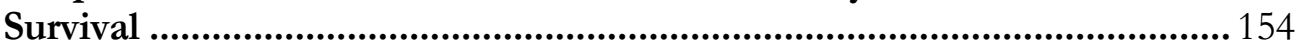

Chapter 6: Community - More Powerful Than Freedom Of Choice? A

Case Study of the West Auckland Competition Polls in February 2003 ... 179

Chapter 7: TSB Bank and TSB Community Trust: A Case Study of

Community Enterprise and Community Support .....................................205

Chapter 8: Invercargill Licensing Trust: A Case Study of Community

Support and Leadership................................................................................. 228

Chapter 9: Cross Case Analysis .................................................................... 256

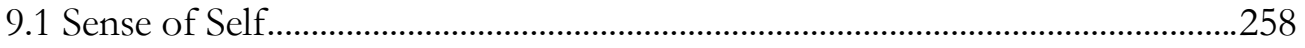

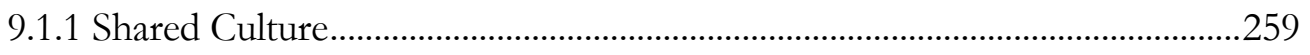

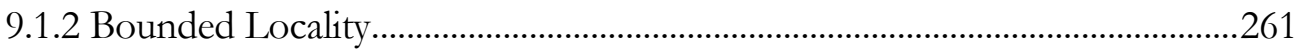

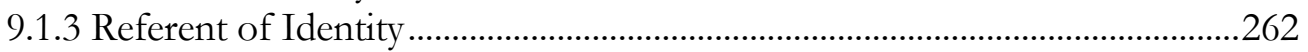

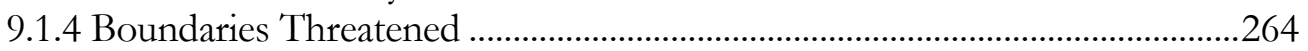

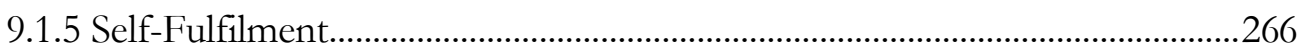

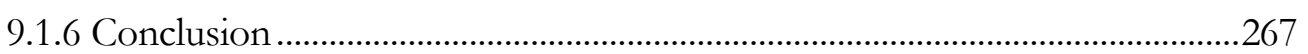

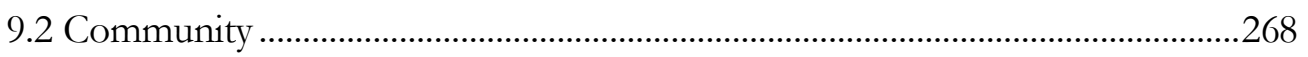

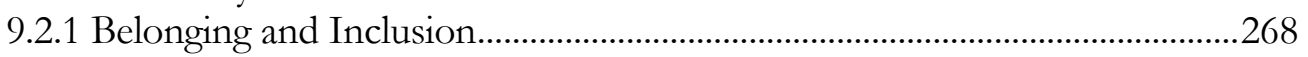

9.2.2 The Common Good.....................................................................................269

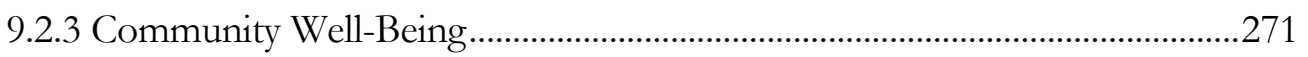

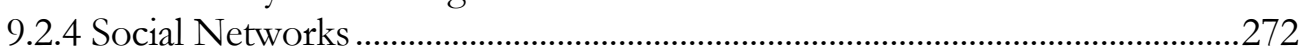

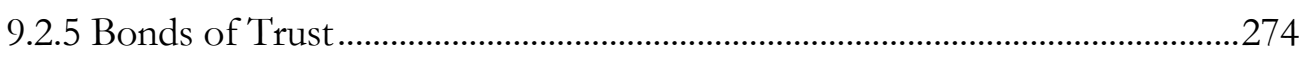

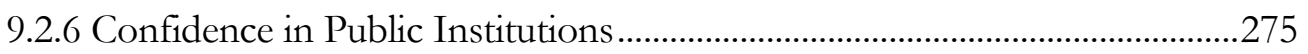

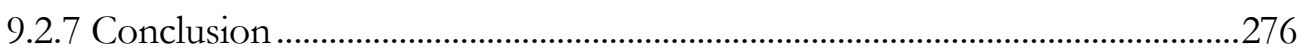

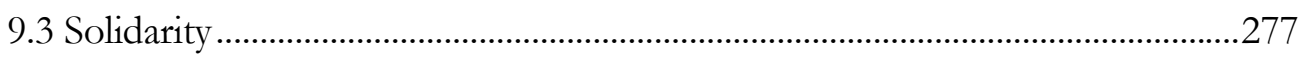

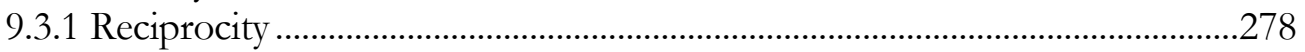

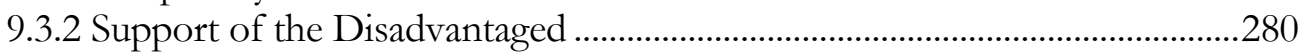




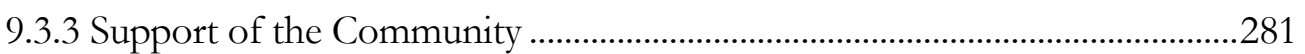

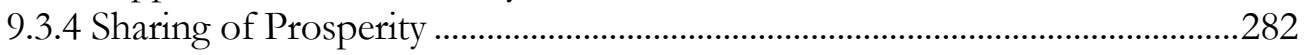

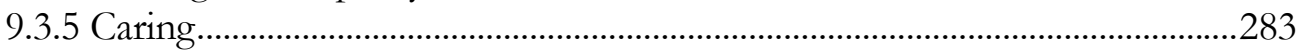

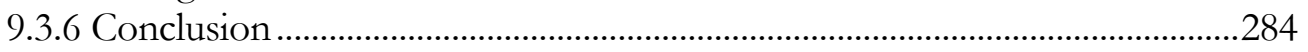

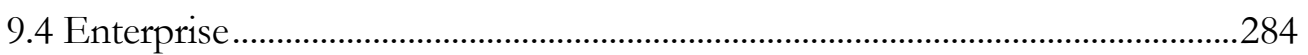

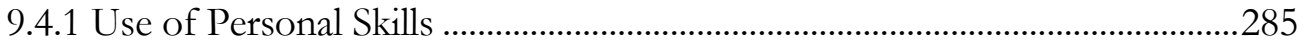

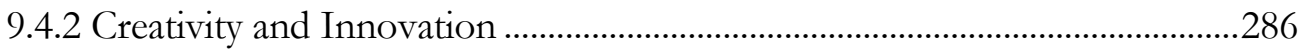

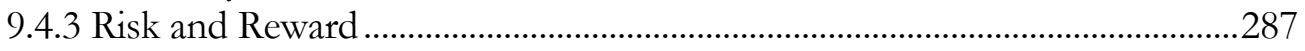

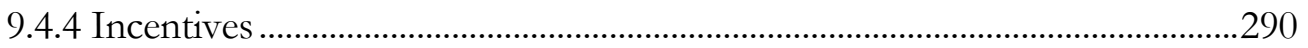

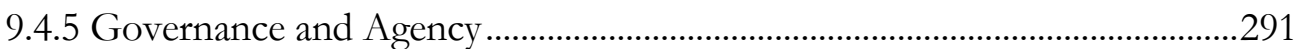

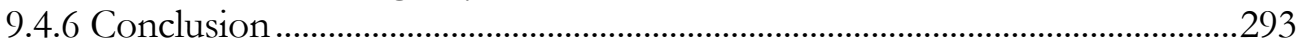

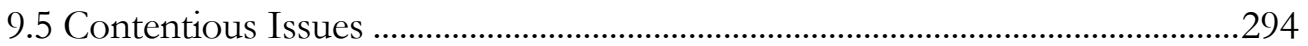

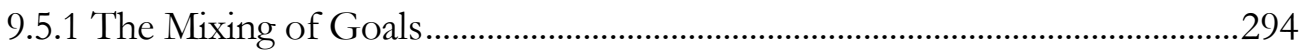

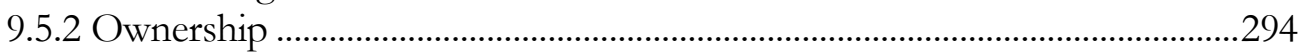

9.5.3 The Need for Profit ....................................................................................295

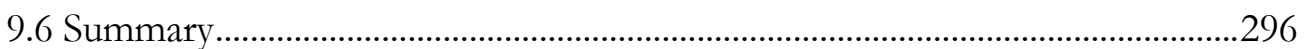

Chapter 10: Conclusions ........................................................................ 298

10.1 A Framework for Community Enterprises ..................................................299

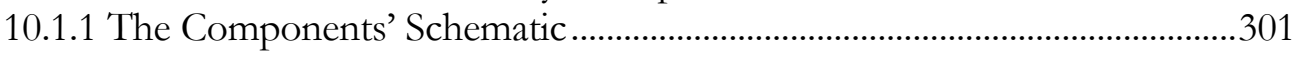

10.1.2 The Degree and Importance of Presence.....................................................307

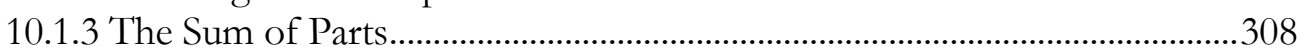

10.1.4 Are Community Enterprises Necessary? ..........................................................308

10.2 When Community Enterprises are Best Engaged...........................................313

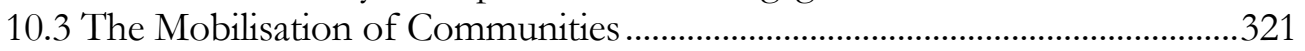

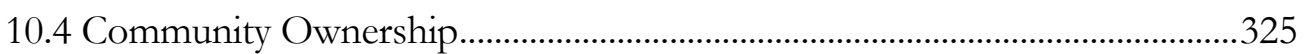

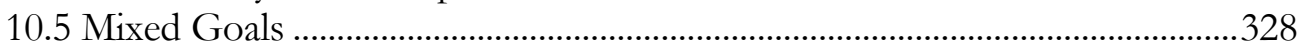

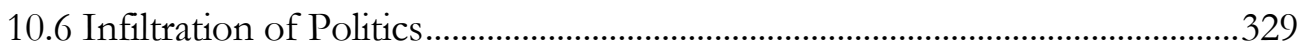

10.7 The Key Thesis Statement: Are Community Enterprises Valued? .................330

10.8 Implications for Theory, Policy and Practice .......................................................332

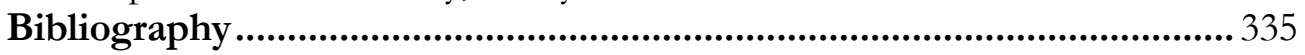

\section{List of Figures}

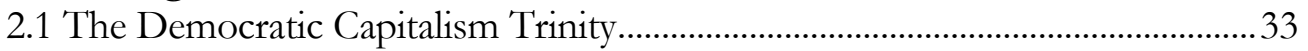

2.2 The Components of Community Enterprises ..................................................67

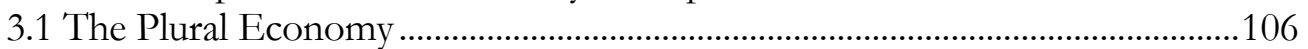

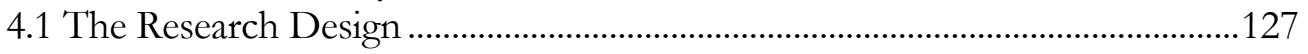

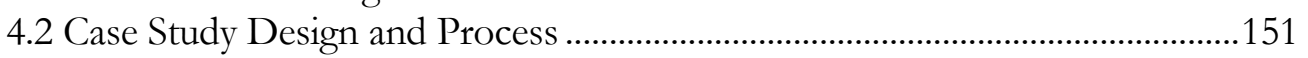

9.1 Community Enterprise Schematic....................................................................256

10.1 The Components of Community Enterprises ....................................................301

\section{List of Tables}

Table 2.1 Constituent Parts of Community Enterprises .........................................101

Table 4.1 Process-Orientated Criteria of Adequacy ...................................................139

Table 4.2 Case Study Characteristics .......................................................................147

Chapter 5 Table 1 Community Ownership: Attractions for Eketahuna ...............163

Chapter 5 Table 2 Population Trends ..........................................................................169

Chapter 6 Table 1 Summary of Lessons ....................................................................198

Chapter 7 Table 1 Review of Performance..........................................................209

Chapter 7 Table 2 Dividend Distribution ...........................................................222 
Chapter 7 Table 3 Comparative Performance of 3 Community Trusts

Chapter 8 Table 1 Review of Performance

Chapter 8 Table 2 Donations Distribution .........................................................247

Table 9.1 Constituent Parts of Community Enterprises ...........................................257

Table 9.2 Presence of Components in Case Studies ................................................297

Vignettes

All's Well With the World? A Personal Experience .......................................................4

Tunisian National Solidarity Fund ................................................................................52

Communities Vote to Restrict Their Members Choices: The Case of

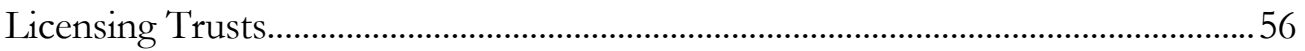

A Sense of Self: The Case of the Long Serving Members .......................................68

A Unique Mandate: The Case of the Masterton Licensing Trust............................. 74

Community Well-Being in Action: Political Compromise: The Case of the

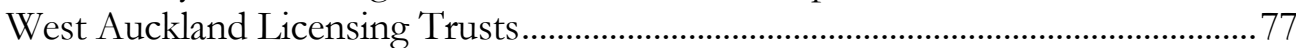

Community Support Through Entrepreneurship: The Case of the Tararua

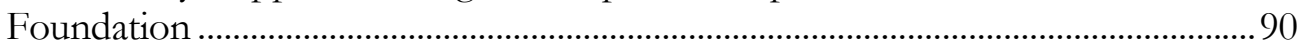

The Need for Profit:: The Case of the Flaxmere Licensing Trust........................... 95

The Case of Trust House Limited .........................................................................112

The Case of the Masterton Trust Lands Trust.......................................................121 


\section{T H A N K S}

I had a dear old friend many years ago. Much loved now more in retrospect for what he taught me. He was old and very wise, yet very young. I was young, probably condescending towards his age and frailties, and knew a lot, with much energy and false confidence that could solve almost any problem. Knowing less now, as the passing of the years teaches you, I have learnt how much I would give to talk to him again, with more humility and perhaps a little closer to his wisdom.

He had been a teacher all his life; for over 50 years when I knew him. He was very gifted, not just in wisdom and knowledge, but also as a teacher, a writer of music, a conductor of school choirs and a leader of students. He taught me in ways that only now I am beginning to understand.

He had a love of rhyme and poetry. He introduced me to some but correctly discerned that I had too much to learn and far to journey before I could appreciate quality and depth. One I did remember throughout the years was Tennyson's Ulysses. My friend was mildly cynical of Tennyson's work, being perhaps too sentimental and romantic for his tastes. Some lines of the Ulysses are quite beautiful in their imagery and their evocative sound; and I take some whimsical enjoyment from:

\section{And this gray spirit yearning in desire \\ To follow knowledge like a sinking star, \\ Beyond the utmost bound of human thought.}

Like my friend, my tastes in poetry have moved on. But the following lines of Ulysses have 'stuck' with me over the almost forty years since my introduction. They are undoubtedly romantic and idealistic but in an at times far too cynical and selfish world, the exhortation is still one for all ages: 


\section{Come, my friends,}

Tis not too late to seek a newer world.

Should we ever cease to do so? The reader will have to answer that personally, for the challenge is to each person and for all generations. For me, what follows is what I 'had' to do. It is the natural progression from the gentle teachings of my friend all those years ago. It reflects his love of exploration and knowledge, and his assertion that education is the key to advancement. It is always the key, for each generation and every nation.

This, then, is my long overdue thanks to John McCaw, lover of knowledge and life-long educator.

I have many others to also thank: my teachers at the Masterton Licensing Trust and Trust House: trustees, management and front-line staff, who showed me, sometimes in very painful ways, the lessons of working with people and how to run a business; and that caring and trust make the difference between the great organisations and those that just exist. The need to care I learnt much earlier from my parents.

My first 'boss', Selwyn Baker, a most remarkable man who typifies deep caring every day, at 90 read parts of this work and scribed copious thoughtful notes for me to reflect on.

I have special reason to thank Karen Baehler, Senior Lecturer at the School of Government in Wellington. A lovely lady in all the nicest interpretations of that description, she had the difficult, and no doubt at times unenviable, task of coping with an 'aged', opinionated student who had much practical baggage and little aspirations to academia. Her sharpness of intellect, integrity and support was ever present. I was never in any doubt whose side she was on. 
Chris Eichbaum, my second supervisor, provided insights and was always another source of support.

I have been roundly chastised by my 'children' for not paying tribute in my two previous theses for all they have taught me. That process, they earnestly tell me, has not been easy, with the inference that I have rarely been a willing or receptive student. Since I intend to seek repayment of previous debts in my dotage and wish to maintain access to my grandchildren, I acknowledge now how much I enjoy their company. To Kim, Aaron, Corey and Gareth (and Jason, Anne, Linda and Mishelle), thank you. To my grandchildren Izak, Kajsa, Alexia, Emily, Noah and Aaliyah, I promise to continue to exercise that inalienable right of grandparents - to spoil with vigour.

Four years of full time study has gone quickly, yet it has been a long time. It has been a time of immense change. The transition from CEO to student was not a difficult one for I think I have always been a student. I have learnt much over this period as I weaved and plodded my way through both brilliant books and articles and the rubbish. And if I have arrived at where I started then it is with different lens seeing more, much more, of the story that is community enterprises. My enthusiasm for the concept, while at times tinged with cynicism and criticism at their shortcomings and the human failings, is undimmed.

If a little of my admiration for the good that they do shines through this text, then I will be content. 
We shall not cease from exploration

And the sum of all our exploring

Will be to arrive at where we started

And know the place for the first time.

T.S.Eliot

From Little Gidding

No. 4 of Four Quartets

\section{INTRODUCTION}

Throughout its history New Zealand has had a love affair with community enterprises. In the nature of love affairs, at times the relationship has been close, at others, distant. At times during the 166 years since the Treaty of Waitangi these forms of organisation have been turned to as a first choice to address an institutional need. At others, the public policy climate has been less than welcoming. Yet throughout these years they have survived both as a concept and a reality. There are signs today of a renaissance. The purpose of this (re)search is to understand why this is happening and why community enterprises have endured.

New Zealand was still a very young colony when the first community enterprises were formed by the earliest settlers. Perhaps the first was the Wellington Savings Bank in $1846^{1}$ (Scott, 2002). Although that Bank was not to last ${ }^{2}$, its sister bank, The TSB Bank, is now over 150 years old and grows from strength to strength. Electricity supply was often provided by

\footnotetext{
${ }^{1}$ Manson and Manson (2001) record that it was formed at the 'behest of His Excellency Governor Grey'. It is not known whether it was the first. No history of community enterprises is known to be written although there are publications dedicated to particular types, for example Savings Banks.

2 It ceased trading in 1872 but in 1964 reformed. Today it is a non-trading community trust distributing community support donations to its community from its investments.
} 
community owned enterprises ${ }^{3}$ and despite the radical reforms of the last ten years, there remain 24 community energy trusts around New Zealand with significant investments in, and ownership of, energy companies. ${ }^{4}$ Notably, at the time of the early 1990s' reforms that brought about the Energy Companies Act 1992, there was initially no provision made for community ownership. It was only the strident agitation of the communities then involved in supplying electricity that generated a reversal. ${ }^{5}$

Another era when community enterprises were the chosen vehicle to address a need was the 1940s. The sale and supply of liquor was entrusted (but not solely) in 26 communities to licensing trusts, a legislated form of community enterprise, with the last gazetted in 1975. Although successive governments have waxed and waned on the concept since then, there remain 20 licensing trusts actively trading today with annual sales close to $\$ 300$ million and assets of over $\$ 200$ million.

And throughout the past 150 years communities have sought to protect their interests by forming, often under the ambit of the charitable trusts or incorporated societies' legislation, such diverse community enterprises as health trusts, local hospitals, education and forestry trusts. Some of these entities were legislated by supportive governments during periods of philosophical affinity while others were generated by grassroots community action.

Perhaps most remarkable of all, the concept and reality of community enterprises survived even the radical reforms of the privatisation era, including targeted opposition from people in the most senior positions of influence. During his tenure as Attorney General, former Prime Minister

3 The first community power boards for electricity distribution were formed in 1918 (see www.ststs.govt.nz).

4 Web-site www.etnz.org.nz records investments of \$5billion.

5 This was told to the writer by a Government official and reinforced by a South Island mayor. Subsequently, by far the greater number of energy companies established were community owned (approximately 75\%). 
David Lange described Licensing Trusts as a 'bizarre social experiment' and an 'endangered species.' ${ }^{6}$ Business leaders were opposing these Trusts from their beginnings in the 1940s according to Bollinger (1967). Barry's (2002) paper is but one example of the New Zealand Business Roundtable's consistent opposition to public ownership.

Community enterprises or their sister organisation, social enterprises ${ }^{7}$, have generated renewed international interest in recent years. The British Government in 2002 released a strategic document promoting greater use of social enterprises to accomplish social and other goals. ${ }^{8}$ Both the European Community $^{9}$ and the OECD (1999) record an expanded role for social enterprises in the European economies. Laville (2003) and Salamon (2003) detail the phenomenal growth of the third sector around the world, of which community and social enterprises are a part. These are signs that 'something curious is happening' and that 'new models of community-based management are spouting forth while old models are rediscovered' (Bollier, 2002).

The two themes of an enduring concept that ebbs and flows in presence according to the needs of the time present several issues. For example, how and why have they endured? Why have their fortunes ebbed and flowed over time?

Additional questions flow from these. Never has the philosophy of the market economy been more dominant. Why therefore can it not provide for all enterprise needs? Under private enterprise there is great freedom for

\footnotetext{
${ }^{6}$ Speech to New Zealand Licensing Trusts conference in Masterton, in June 1990.

7 The name social enterprise is more common in the United Kingdom and Europe. Community enterprise is more applicable to New Zealand because of their historical linkages to the community. That recognition is illustrated in recent years by the community trusts' legislation of the late 1980s.

8 Social Enterprises: a strategy for success. (UK) Department of Trade and Industry. On web-site www.dti.gov.uk. A 'crude estimate' of the size of the UK social enterprise economy suggests there may be around 5300 in number (ECOTEC, 2003:5) and employ 6.5\% of the UK's employment (Passey and Lyons, 2004:2)

${ }^{9}$ The European Report of January 242004 while noting that social enterprises provide ' 700,000 jobs in the acceding state' advocates they be given 'greater attention'.
} 
individuals to pursue their own aspirations. As economic activity lifts, wealth increases and governments are better placed to support those who temporarily or permanently are unable to provide for themselves. Has not the privatisation literature clearly shown that public ownership (which surely captures community ownership) is less efficient than private enterprise when operating trading entities?

To answer these issues requires some definitions. But before that a personal presentation and positioning is desirable.

\subsection{A PERSONAL JOURNEY}

This research cannot and should not be isolated from the practical experiences that precede it. This is the work of one who has 'lived' the concept, 'agonising' over why community enterprises should exist and what was different about them; lived during a period when the market philosophy was rampant. Any practitioner who has senior management responsibility will readily empathise with the periodic but constant conflicts that are part of the task. The 'agonising' here is an accepted component that, while rarely enjoyed, is part of the day to day routines. But when the nature of the organisation came under threat, this added challenge demanded, for me, some philosophical and practical answers.

I worked for almost 30 years in community enterprises. The starting point was the Masterton Licensing Trust which at the time of my joining had been in existence for 25 years, owning and operating a small number of hotels, bars and restaurants. It was then moderately successful, enjoyed a moderate degree of support from the community and had a very limited community support role. From early success and significant public support it had moved into a reassessment stage where performance was patchy and conflicts emerging, with community expectations becoming increasingly challenging. Inevitably, its role and justification was part of those challenges. The end point thirty years later was nine community enterprises with a much expanded and diverse 
range of businesses, both geographically and by type. Community support (donations) was now a major function and the organisations were significant employers in their communities and widely viewed as 'essential' to local quality of life. The story in-between is not the issue here although parts have been used in the vignettes to illustrate important propositions.

The successes achieved demonstrate in a way that theory rarely can, that the concept worked. But despite much reading and two reasonably large academic research projects over the years, aspects of the conundrum that was community enterprises remained elusive. Practical experience proved they worked, at least in the circumstances of my experience. They were not without problems but the dissents that arose were manageable. For example, political agendas and conflicts were rarely so difficult that solutions could not be found, and the politics associated with community boards was consistently more positive than negative. Some researchers' belief that it was unwise to mix social/community goals with economic goals under one management was rejected by the knowledge that this was an everyday reality that almost never caused an insolvable conflict of interest. But 'deeper' questions persisted. What was this almost 'mystical' element that endeared the concept to the community? Extensive contact with very many people in the community over the years asserted, as one of those 'known truths', that people liked community enterprises and were even prepared to tolerate indifferent performance or conflicts (for a while, at least) to retain them.

They worked and they were valued. Or at least, that was my practical lesson born out of years of experience. But there were failures also and detractors, sometimes strident ones. The political climate was only occasionally enthusiastic over those years. The dominant impression from discussions with politicians and private enterprise business leaders, and appearances before select committees of Parliament, was occasional opposition, lukewarm support and regular rearguard defence of benefits previously granted in more supportive times. The question more and more insistently arose. Why could 
not other people see the benefits flowing to the communities in which community enterprises successfully operated: the Invercargills, the Taranakis, the Mastertons? No doubt an element of the enthusiast's zeal was involved. But even in a cynical world, surely the enthusiast has their place? Nonetheless, if advocacy was to be pursued the questions needed to be answered and the conundrums solved.

This (re)search is the logical progression. What follows must be seen in the context of practice. The writer comes to the work searching for answers but knows that, such is the nature of community, the answers may be elusive and unlikely to be complete. He knows that a questioning and rigorous discipline is essential but believes that advocacy also has its place. Given the years of practical conditioning, he comes with the 'baggage' that complete objectivity and emotional remoteness are not part of his 'armour'. But then is not complete objectivity perhaps illusory? It is perhaps best to rest on the statement, boldly put: the writer is a practitioner searching for answers.

\subsection{THE NATURE OF COMMUNITY ENTERPRISES}

Community enterprises are primarily concerned with the well-being of their defined community, which may be a generic community-wide solicitude or specific to a group or sector. The definition may be bounded geographically and/or to a categorical interest. They provide that support through the ambit of their trading enterprises. They may trade simply to generate profits to support their primary purpose, for example, to provide employment generally or for a disadvantaged group; or to supply a service desirable or essential to the community. They do not need to be driven to generate the best return on their investment, but they must exercise the normal commercial disciplines or they will not survive. 
They may be classed as part of the third sector ${ }^{10}$ and a hybrid form of organisation that crosses over sectors, a mixture of market orientation and solidarity. An appropriate definition is:

A community enterprise is a business whose primary goals are to support the well-being of its defined community principally through reinvesting profits generated from its trading activities either in the business and/or in support of community activities, rather than being driven to maximise profits. ${ }^{11}$

Community enterprises are a lightly and sparsely researched field, and although a sizable literature is forming around the third sector, that field remains highly diffused. There is no known conceptual framework for the former but through Salamon's (and Anheir) (1997, 2003) work from Johns Hopkins University, better definition is now happening around the latter. ${ }^{12}$ Bollier's (2002) extended quote in section 2.2.2 highlights the general uncertainty concerning the sector.

Community enterprises in New Zealand have not been the subject of in depth research. There have been a few Masters theses on licensing trusts and the energy trusts, for example, Teahan (1990, 2000), Bogle (1983), Nelson (1994). McKinlay $(1999,2001)$ has explored community trusts in some detail and his work on what he calls their 'ownerless' nature has aspects which this thesis contests. But community trusts are not community enterprises unless they

\footnotetext{
10 The market economy, non-market economy where the principle of redistribution is governed by the welfare state, and the civil and solidarity-based economy are generally recognized as the three sectors. The latter has a number of names: the civil society, the non-profit sector, the social/solidarity based economy...Laville's (2003) title is preferred.

11 This definition has similarities to the UK Department of Trade and Industry's (2002) (see note 8) but places greater emphasis on the well-being of a community, which is the nature of the New Zealand experience.

${ }^{12}$ Laville's $(1999,2000,2003)$ research is also influential and helpful.
} 
actively operate trading enterprises, and only the TSB Community Trust occupies that category. ${ }^{13}$

Certain aspects of the thesis have been studied extensively. For example, the notion of community is one of the most written about subjects in the social sciences. Concepts of (private) enterprise and the market economy are well researched as are other components of community enterprises, solidarity and self-fulfilment (sense of self). Community enterprises holistically, however, have received quite limited attention.

In very recent years social enterprises in the United Kingdom and Europe have received research attention from Government commissioned sources [for example, ECOTEC (2003)] and private researchers [for example, Passey and Lyons (2004)] but in New Zealand research on the contribution that community enterprises have made to communities and their way of life is limited. Certainly, there have been locally commissioned papers and historical publications [for example, Henderson's (1997) fine work on the Masterton Trust Lands Trust] and these are helpful in understanding historical contexts and justification.

\subsection{THE RESEARCH QUESTIONS AND CONCLUSIONS}

This thesis pursues the practical theme of seeking to better understand community enterprises: what they are, what they do, and where they 'fit' in today's world order.

Practical experience led me to the belief that provided they exercised the normal management disciplines, community enterprises performed (at least) satisfactorily, and were valued by their communities. But this belief needed to be tested in a wider context in New Zealand, ideally among different types of community enterprises; and international experience needed to be gathered so as to place the New Zealand trends and examples in their global context.

13 That Trust and its wholly owned bank is the source of the case study in chapter 7 . 
In this pursuit of knowledge about community enterprises, the potential weaknesses of this organisational form as previously suggested by practical experience and other writers, must also be addressed. This leads to three central questions: Are community enterprises 'ownerless' as McKinlay (1999) suggests? Does the pursuit of mixed goals - social/community and commercial - present conflicts of performance? And does the lack of a traditional equity source constrain performance?

Finally, the research would seek to define when community enterprises are best engaged.

In summary, the questions the thesis addresses are:

- What are community enterprises?

- What do they do?

- Where do they fit in today's world order?

- Do communities value their community enterprises, and if so, why?

- Do communities mobilise to establish, protect and perpetuate their community enterprise, and if so, why?

- When are community enterprises best engaged?

The conclusions reached are detailed in chapter 10. In brief, the research presented here finds that community enterprises are valued by their communities, many of which will mobilise to protect and defend them, so as to perpetuate their existence. But mobilisation does not always occur. At times, some communities will allow their community enterprise to fall into demise. Why this occurs is not fully understood, but chapter 10 seeks to shed 
light on the question by extending Cohen's (1986) explanations in a New Zealand context.

To reach these conclusions necessarily requires a discussion of the key forces influencing the world order and shaping the niche occupied by community enterprises within that order. Global forces are creating levels of interdependency and economic wealth never before experienced. The rising tide syndrome is reducing world wide poverty to unprecedented levels. Yet conflict, crime and dissatisfaction are increasing rather than diminishing. Huge gaps in standards of living and desperate needs are often passed by in the global rush. As organisations become larger, they run the very real risk of becoming remote from communities and individuals. For these reasons, it is important at this time to better understand the nature of community enterprises and their performance and contribution in order to answer the urgent call for new and renewed institutions to meet the needs of the current age [Giddens (1999), Stiglitz (2001), and Putnam (2000)]. ${ }^{14}$ As Laville (2003) and Salamon (2003) have pointed out, the growth of the third sector, which includes community enterprises, can be seen in part as a reaction to pressures created by new technologies and globalisation. It is not possible to understand community and individual pressures in isolation of these key world pressures, as many authors attest[for example, Novak (1991), Shore (2001), Gates (1998), Wolf (2004), Shuman (2000)].

Reaching the conclusions stated above requires an intimate knowledge of their essential nature, that is, what community enterprises are, and what they mean to the individuals and communities that operate and support them. Thus, one of the key goals of this research was to identify the essential principles that define community enterprises and determine their particular niche within civil society and the system of democratic capitalism. Four guiding principles of community enterprises - a sense of self, the need for community, the pursuit of solidarity principles, and enterprise - are

\footnotetext{
14 See quotes at the beginning of chapter 2 .
} 
identified, linked and interwoven in a schematic in which, paradoxically the individual is both the core of the theoretical framework, and also the glue that holds the other principles together in a coherent whole.

That being said, it would be wrong to infer that individualism, or any other single principle, represents the key pivot for explaining community enterprises. Take away any one of the four components and what remains is a very different organisation to community enterprises. Each of the four components is a separate, and extensive, topic in its own right. To understand each, the thesis draws upon selected literature in those fields: Cohen on sense of self, Fowler on community, Gewirth and John Paul II on solidarity, and Seldon (and others) on enterprise. No one author fits together the parts into the whole that are community enterprises. Each author takes us so far but is not sufficient on his own. To understand community enterprises requires us to combine a number of themes and to step into uncharted territories.

\subsection{APPROACH}

When a practitioner turns researcher and considers the methodological choices and debates, it would be surprising if, at least occasionally, they did not despair. The impression that everything is contested and contestable seems inherent. The rules of the game appear to be, frequently simultaneously, vague yet specific, free spirited yet prescribed; they add up to a menu of staggering extensity covering all poles of extremity, from statistical rigour to 'thickly described' storylines. Even the names of the different methodological choices, while impressive in their inventiveness, seem to be able to mean different things at differing times. The debates on, for example, the status of the subjective, positivism versus postpositivism, the 'relentless search for certainty' (Barber, 1984:17), at times seem to take on something akin to the holy wars where different beliefs are advocated almost as absolutes.

A practitioner invariably faces other difficulties. At the senior levels of management they are used to multiple realities where knowledge of the 'full 
facts' is often a luxury and yet decisions have to be made. They often work in 'five minute bites' where complexity is frequently present. They make sense of their world in a way that may appear to haphazardly mingle values and facts. (Yet it is rarely haphazard.) They know that much of the information they gather, and are given, is 'soft' and subjective but is not rejected, often more valued, because of that. Their 'real world' is rarely given to circumstance where cause and effect can be isolated to one or two factors. The disciplines and tasks they ebb and flow in and out of can routinely, even daily, cover law, accounting, marketing, politics, economics, psychology, strategic planning, organisational structure and behaviour, sociology, philanthropy, anthropology... Often they would not even recognise, or bother to do so, that the task they are dealing with belongs to one or more of these fields. It is a world of tasks; tasks of often great variability. ${ }^{15}$

The practitioner makes sense of their world, as do many others, by a personal system of values interlaid with (most often but not always ${ }^{16}$ ) organisational values, rules and protocols. It is, predominantly, an ordered world, although the order may be transitional and aspiring. The combination of factors that are brought together in any one practical moment of decision can be significantly variable.

When the practitioner seeks to translate these variabilities into credible research (assuming a belief that there is something of value to impart) the complexities of the translation are added to the methodological confusion. The approach to research that results, is a mix of experiential evidence, evidence collected through research methods, personal values and beliefs, and the theoretical and philosophical frameworks that emerge from broad exposure to a wide range of conceptual literature.

\footnotetext{
15 This is not intended to even remotely cover a manager's tasks and work habits. What is sought here is to contrast the different working worlds - practitioner versus researcher - so as to better explain the methodological choice adopted.

16 Almost all organisations have norms, either expressed or 'understood' (or both). For some organisations the norms are ignored or are ineffective, often a recipe for dysfunction.
} 
In the beginning, the belief driving this thesis was simply this: community enterprises are a good creation, both in concept and in practice. They work (efficiently and effectively), most of the time. People (communities) are attracted to them. They contribute to a better society. But they can also be inefficient and wasteful, and sometimes they fail. They are not for every enterprise circumstance. These simple starting beliefs, born of many years of experience of seeing community enterprises in the best and worst of times and circumstance, sit alongside the corollary belief, also based on the writer's experience, that for the vast majority of business activities, the private enterprise or market economy system is the appropriate choice. ${ }^{17}$ These core assumptions, that private markets work well most of the time, but community enterprises also have a role to fill, naturally led to the question of when under what conditions and circumstances - community enterprises work best, and whether they are used as often as they could be when these circumstances arise.

The thesis addresses these questions in two ways: through empirical investigation of four contemporary New Zealand cases in which community enterprises have been the chosen vehicle for service delivery and collective action, and through construction of a philosophical and theoretical framework that helps explain the principles and values that animate these cases.

The search for a methodology that could capture the practical world realities while also drawing out the philosophical foundations of practice, led the author to construct a multi-method approach encompassing a variety of disciplines. The literature search helped capture the nature and character of 'community', which is the single most important point of difference for community enterprises in comparison to other forms of enterprise. Gates (1998), Fowler (1991), Shore (2001), Cohen (2000), Stake (1995), Walters and Sudweeks (1996), Forester (1993), Kaplan (1993) and Fischer (1998, 2003) all

\footnotetext{
${ }^{17}$ For a treatment of these issues, see section 2.1.
} 
pay tribute to the story as the way to best understand the richness and complexity of community. It is Fischer and Fowler who provide the most compelling argument for using stories and storylines to capture what Toulmin (1990:27) calls the 'rich perspective of human affairs'. This thesis tells the story of community enterprises in contemporary New Zealand through four cases: Eketahuna and its tale of small town survival, West Auckland's revealed preference for community action over consumer choice, a Taranaki-based example of how smart business and community support goals can reinforce rather than compete with each other, and Invercargill's leadership model of community enterprise.

Fischer's (2003) treatise on postpositivism is particularly relevant to the problem of bridging theory and practice (particularly when little or no theory is available on the topic). He describes an approach in which empirical inquiry is pursued within a broad, interpretive framework, where the empirical is embedded in the normative, data is examined through conflicting frameworks, practical reason is valued for its insights and a multi-disciplinary and multi-methodological approach 'opens the door to a more subtle and complex form of rigor' (:132). This is the approach that guides the thesis.

The methodology is more fully described and justified in chapter 4 but for the purposes of this introduction can be summarised as:

- multi-method, adopting, predominantly, the rigours of case study as the best vehicle 'to understand (the) complex social phenomena' (Yin, 2003:2) that are community enterprises;

- multi-disciplined, adopting, where appropriate, the characteristics of the lawyer, accountant, marketer, politician, economist, planner and strategist, manager and philanthropist; and

- embracing the stance of the postpositivist. 


\subsection{OUTLINE OF THIS THESIS}

Chapter 2 discusses the key philosophical and theoretical bases to community enterprises, beginning from a wide perspective and narrowing down to the component parts that contribute to make the concept unique. Interspersed are vignettes. Chapter 3 takes a more practical perspective detailing community enterprises' presence and the structure and form in which they are presented. Important here are Laville's (1999, 2000, 2003) and Salamon's (2003) revelations on the third sector phenomenon. The mix of methodologies used in this thesis is detailed in chapter 4. The four community enterprises selected for in depth study are presented in chapters 58 and in chapter 9 are analysed under their 21 constituent parts. Chapter 10 concludes with the thesis' findings.

Because the concept has been sparsely researched, the approach herein has been holistic and generic to community enterprises. It is thus an 'overview' endeavour. A framework better explaining what community enterprises are and where they work well is the key aspiration. Financial performance is also examined briefly, to enable some comparison between commercial and community enterprise models. Finally, contrary philosophies and contentious issues are also addressed, but are not found to pose a serious challenge to the central conclusion. All of these issues are worthy of further research. 
Chapter 2

\section{THE PHILOSOPHICAL AND THEORETICAL BASES TO COMMUNITY ENTERPRISES}

Many of us feel in the grips of forces over which we have no control.... The powerlessness we experience is not just a sign of personal failings, but reflects the incapacities of our institutions. We need to reconstruct those we have, or create new ones, in ways appropriate to the global age.

Anthony Giddens (1999)

The challenge.... will be to strike hard-to-find balances between the roles of the state and the roles of the private sector, and between the doctrinaire positions that have often characterized the policy advice of the past and the agnosticism that gives little guidance to those struggling to make the hard choices that will affect million of lives.

Joseph Stiglitz. (2001)

...we desperately need an era of civic inventiveness to create a renewved set of institutions and channels for a reinvigorated civic life that will fit the way we have come to live.

Robert Putnam (2000)

\section{BACKGROUND}

Giddens and Stiglitz reflect the dichotomies that exist in this complex, interwoven yet frequently alienating world of the twenty-first century. Great advances have been made, particularly in the last quarter century in so many fields of endeavour - medicine and technology to name just two - and yet conflict is a constant presence, reflected not only in international wars but 
also locally and nationally in crime and intolerance (for example, road rage, a recent phenomenon). ${ }^{18}$

Although discord and conflict may be basic to the human condition ${ }^{19}$, and therefore impossible to eliminate, the lessening of conflict and the aspiration of a more harmonious society locally, nationally and internationally is of interest and benefit to us all. This thesis begins with the belief that marginal progress, at the least, is always possible.

On one side of the progress-conflict dichotomy is the immense changes that have occurred in quite recent times in the world order. The fall of communism is one such event perhaps best imagined by those emotional pictures beamed throughout the world of the destruction of the Berlin wall. But one event can not capture the enormity of the change that led one author (Fukuyama, 1992:1) to hypothesise in his End of History and the Last Man:

'My hypothesis was that there was such a thing as a single, coherent modernization process, but that it led not to socialism or to a variety of culturally-determined locations, but rather to liberal democracy and market-orientated economies as the only viable choices. The process of modernization was, moreover, a universal one that sooner or later would drag all societies in its train. ${ }^{20}$

While that hypothesis was undoubtedly radical, even more notable was Fukuyama's 'views that liberalism, capitalism, and democracy are preferred because they reflect truths of buman nature' (Binder, 1993:10). That premise has echoes in the teachings of the Catholic Church and John Paul II's assertions [for example,

\footnotetext{
18 Putnam (2000:142-3) records that 'violent aggressive driving' increased more than 50\% between 1990 and 1996 and that road rage 'is a factor in twenty-eight thousand deaths per year' in America. This remarkable statistic must, in this writer's eyes, be subject to some question as to accuracy but it is quoted here to give impact to the societal characteristic of conflict and its rapidity of increase.

19 A degree of contestability is undoubtedly desirable: as George Bernard Shaw whimsically wrote: 'The reasonable man adapts himself to the world; the unreasonable one persists in trying to adapt the world to himself. Therefore all progress depends on the unreasonable man,'

20 As can be imagined, this hypothesis and Fukuyama's work gave rise to, at times, fierce rejection and significant controversy. Samuel P. Huntington's writings are one stream that take a different view to Fukuyama.
} 
Centesimus Annus (1991:47)] that societies must provide basic human rights and freedoms: the right to life, the right to (supportive) family and community, the right to grow as an individual, the right to work and to share in the rewards of that work so as to support their family.

Barely 14 years have passed since the publication of Fukuyama's work and the rapidity of change is no less intense. Socialism has fallen from grace (Seldon, 1990; Novak, 1991:187) as a workable theory. Democracy and capitalism have spread $^{21}$ largely undaunted by their deficiencies and failings. We have greater agreement than ever before on the systems of social and economic organisation. Yet, the other side of the dichotomy is ever present. Why is there so much conflict in society? Why is the world not a safer, better place? ${ }^{22}$

The answers to these questions, if there are or ever will be complete answers, are complex, contestable, and not the purpose of this thesis. They are, however, relevant to the existence of community enterprises because these hybrid organisations offer opportunities for addressing alienation and conflict in the contemporary world while also supporting the growing global consensus in favour of democratic capitalism. If community enterprises have proven to be a vehicle to supplement and support the democratic capitalist system that has delivered so much during the latter half of the $20^{\text {th }}$ century, then they are worthy of renewed interest and enhanced support in New

\footnotetext{
21 The proportion of people throughout the world living in poverty has fallen from $56 \%$ in 1980 to $23 \%$ in 2000. Since 1980, 81 countries have taken significant steps towards democracy and of the world's approximately 200 countries, 140 now hold multi-party elections (Emmott, 2003). The World Trade Organisation now has 147 member countries with a further 25 in the queue for membership (www.wto.org).

${ }^{22}$ It is acknowledged that both the question and the answers are significantly subjective. For very many people the world is a better place. Poverty levels have fallen. The percentage of starving people in the world has fallen from 35\% in 1970 to 17\% today (Lomberg, 2003:10). Lomberg also states: 'Today, we have more leisure time, greater security, fewer accidents, better education, more amenities, higher incomes, less starvation and more food. We are healthier and we lead longer lives. This is true for the industrialised world, but it is also true for the developing world.'

But the number of people in poverty is estimated to be still 1.1billion (Emmott, 2003). Crime rates have risen throughout the 1990s (Sanders and Billante, 2002:6). They record that in Australia the number of crimes per 10,000 population rose from just on 500 in 1964 to 4000 in 2000, a position not dissimilar to New Zealand and England.
} 
Zealand and elsewhere. Their survival as a concept and their successes over a period of better than 150 years at the least suggest they have attributes of positive consequence.

But that history suggests much more. That they have endured implies they have characteristics that endear them to communities and to their people. Worldwide examples reinforce that belief. But this thesis also advances the notion that there are underlying truths of human nature why community enterprises 'endear' and 'endure'. Those truths are contained in their component parts: community (well-being, the common good, inclusion and solidarity) and enterprise (the concept that by using one's skills to benefit others, I also benefit).

It is therefore not surprising that community enterprises are generating fresh attention, for example from Bollier (2002) Laville (1999, 2000, 2003) and Salamon (2003). As articulated by the British Prime Minister Tony Blair (Department of Trade and Industry, 2002): ‘... social enterprises ${ }^{23}$ are delivering high quality, lower cost products and services. At the same time, they create real opportunities for the people who work in them and the communities they serve.... The combination of strong social purpose and energetic, entrepreneurial drive can deliver genuine results.'

Stiglitz's words 'hard to find balances' (quoted above) point up the challenges for policy-makers, entrepreneurs and communities who are seeking the optimal mix of public and private activity. The premise particularly prevalent during the 1980s and early 1990s that the market economy could deliver the greatest good if only governments got 'out of the way, liberalize (d) trade, and ... development would follow' (Stiglitz, 2001:345) ${ }^{24}$ has proven to be overly simplistic (Murphey,

\footnotetext{
23 The term 'social enterprise' as used in that document is consistent and interchangeable with 'community enterprise'. The latter is preferred for this work because it is more familiar for the New Zealand scene; for example, community trusts (Scott, 2002; McKinlay, 2001).

${ }^{24}$ It should not be inferred that Stiglitz supported this belief. His article traces the history of prevailing economic development views.
} 
1999; Kuttner, 1997; Hayek, 1951). Fukuyama (1995:17) was curiously unscientific (or seemingly so) when he suggested that free-market economics is about $80 \%$ right. There is perhaps some intuitive support for this assertion even if the percentage appears to be based on limited data. Fukuyama's adjacent assertions $[(: 13)$ '...there is a missing twenty percent of human behavior about which neoclassical economics can only give a poor account. As Adam Smith well understood, economic life is deeply embedded in social life, and it cannot be understood apart from the customs, morals, and habits of the society in which it occurs. In short, it cannot be divorced from culture'.] have more credibility for it surely would be unwise to infer that economic life or free-market economics is the cornerstone for all human beliefs and values. Economics' importance as the means to the end of enhancing and supporting the quality of human life should not be diminished, but neither should the means be confused for the goal.

The challenge for this thesis is to identify the place of community enterprises in a broadened and balanced set of policies that seek to offer inclusion ${ }^{25}$ for individuals and communities, thereby lessening conflict, while also supporting a robust system of democratic capitalism. Latham's (2001:27) stricture that 'a strong society can only come from strengthening the bonds of trust and mutuality between each of its citizens' offers compelling logic, particularly if community enterprises can deliver that trust and mutuality. If they can, then perhaps community enterprises have an important role to play in Fukuyama's missing twenty percent.

Meeting the challenge of the thesis requires a theoretical and philosophical framework for exploring what community enterprises mean to contemporary society. Specific normative frameworks for understanding and justifying community enterprises do not exist, unfortunately, perhaps because little

\footnotetext{
25 The principle of inclusion is both simple and complex. The complexities are reflected in the concept of community discussed later in this chapter but in the context here, inclusion is intended to mean what Gates (1998:xxi) writes: 'My hypothesis is simply this: people are likely to become better stewards of all those systems of which they are a part - social, political, fiscal, cultural and natural - as they gain a personal stake in the economic system, with all the rights and responsibilities that implies'.
} 
scholarly work has been done on the topic and what analysis does exist tends to focus on practical purposes rather that philosophical rationales. Legislation explains the purposes behind particular community enterprises in New Zealand (for example, the Licensing Trusts Act $1949^{26}$ for licensing trusts, and the Masterton Trust Lands Trust Act 2003 for that specific authority), while a document like the UK Department of Trade and Industry's Social Enterprises: a strategy for success explains what they do and aspire to do. But this does not amount to a full justification of their place within the larger society. Thus, although this is a thesis based on practice, the author undertook an extensive search across disciplines for a normative framework that could capture all of the philosophical principles and values that constitute the experience of community enterprises.

In the end, although some came close, none of the existing 'off-the-shelf frameworks was found to be adequate to the task of describing how people and communities, in their everyday activities, succeed in resolving (or at least successfully managing) the kinds of conceptual tension that keep social scientists and philosophers occupied for their entire careers: for example, tensions between liberalism, neoliberalism, democracy, social democracy, individualism, communitarianism, the common good and market freedom. In the absence of an adequate existing theory, the author sought to craft a custom-made, fit-for-purpose framework from those components of the existing literature that corresponded best with his experience, observation, and feel for the subject.

This chapter describes the core elements of that custom-built framework. The structure may be said to begin with Catholic teaching on social justice, which places human dignity at the centres of all debates about optimal economic and social design and implementation. From this essential core, Catholic social teaching, as articulated by John Paul II and others (for example, the second Vatican Council's Declaration on Religious Freedom [Dignitatis

\footnotetext{
26 Now incorporated into the Sale of Liquor Act 1949.
} 
Humanae, 1965]), offers a highly sophisticated and principled foundation for rapprochement between the allegedly competing concepts of responsibility and freedom, community and the individual, and market capitalism and social action. $^{27}$

But even this rich body of thought is not sufficient to fully illuminate either the multiple features of the contemporary landscape that describe community enterprises' particular niche in society, or the specific set of values and principles that explain and justify the endurance of this organisational form over time. To do so, necessitates turning to a number of authors who have specialised in the components that embody community enterprises.

This chapter is divided into three main sections. Firstly, the scene is set through discussion of the predominant world order under the sub-titles of democratic capitalism and a global age. The need for community rounds out this first stage but in order to complete the picture, a range of associated concepts and issues are presented, solidarity, subsidiarity, social capital, and corporate social responsibility. The second section provides a framework for community enterprises. Herein, the factors that contribute

27 A good deal of consideration was given to developing in this thesis the linkages between Catholic social teaching and community enterprises' place in the social order. In the end, the decision was made not to do so, but rather to let the concepts speak for themselves. A brief summary of these linkages follows in this footnote by way of background.

The principle of subsidiarity logically flows from the centrality of human dignity. Subsidiarity seeks that decisions and power should be kept at the lowest level possible of society, commensurate with the common good. Thus the individual (subject again to the common good) should be free to exercise their initiative and their energies to pursue their interests. But this freedom is an ordered liberty, that is, the freedom within the law 'to do what we ought to do' (Younkins, 1999:14). This concept of ordered freedom is not a 'freedom conceived as radical personal autonomy' but a freedom conditioned with responsibilities and 'ordered to the fullness of buman life, to the preservation of buman dignity, and the safeguarding of buman rights' (Weigel, 2000:5).

Liberal democracy, states the Catholic Church, best meets these principles. But democracy, taught John Paul II, can not be value-neutral. It must be subject to moral norms. It must have values (Centesimus Annus, 1991).

The enhancement of civil society and not undue reliance on the State will better deliver social justice (Novak, 1999: 90) and again logically flows from the inalienable dignity of the human person and the principle of subsidiarity. A person must not just accept responsibility (self government) for their actions but should also recognise their responsibilities to others in society (the common good) and for those less fortunate. This latter gives rise to the principle of solidarity, again a fundamental influence in this work. 
to community enterprises being an attractive proposition in defined circumstances are discussed. A sense of self, the human need for selffulfilment, when married to a sense of belonging reflected in the love of community, the pursuit of solidarity and enterprise attributes, contain the key philosophical base for community enterprises. Finally, three contentious issues for community enterprises are canvassed: the mixing of goals, ownership, and the need for profit.

\subsection{SETTING THE SCENE FOR COMMUNITY ENTERPRISES}

\subsubsection{DEMOCRATIC CAPITALISM: THE ROAD TO SUCCESS AND THE SEEDS OF CONFLICT}

Michael Novak (1991:14) provides a definition: democratic capitalism is 'three systems in one: a predominantly market economy; a polity respectful of the rights of the individual to life, liberty and the pursuit of happiness; and a system of cultural institutions moved by ideals of liberty and justice for all.' It is thus a trinity of systems in one with three component parts: a market economy, liberal democracy, and a moral-cultural order.

FIGURE 2.1

\section{THE DEMOCRATIC CAPITALISM TRINITY}

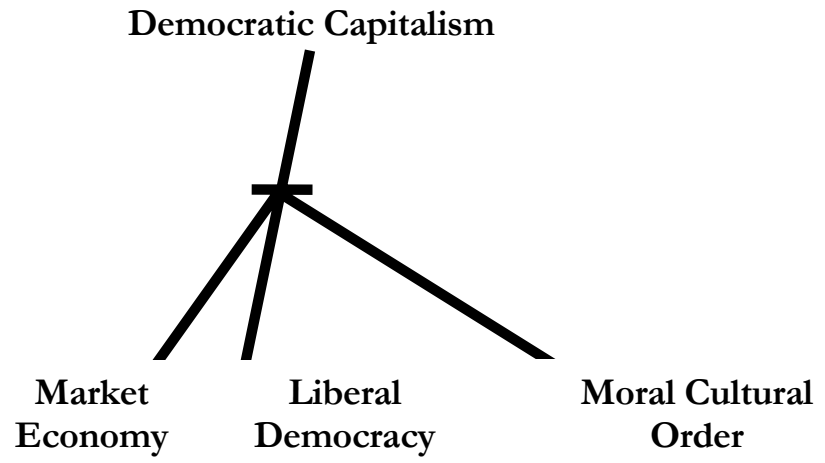


Much like a tripod, adjustments in one part will affect the others. A difficult balance is always required. And such is human nature, all parts will rarely if ever be in equilibrium. But that should not deter from seeking those hard won balances. History does give important lessons which if we are astute enough will lead us to recognise fundamental principles. David P. Gardner, then President of the University of California, expressed this concept well: 'Life too is a process of accommodation; give a little, take a little, get agreement, get it done, concede, insist, seek consensus. It should be of grave concern to each of us, however, if accommodation surpasses, or suppresses principle. Worse still, if such shunting aside of principle occurs less out of malevolence or greed or ego, than out of ignorance. To understand the basis of enduring principles and knowing where, and when, and how, and under what circumstances they should remain inviolate is fundamental to living and life' (1984:665).

To understand these enduring principles is therefore the challenge.

Novak argues compellingly that political democracy is only achievable within a market economy (:14). One can not occur without the other. And both are supported and nourished by significant degrees of freedom to act within a strong juridical framework. Wolf (2004:xvii) explains it this way: The market is the most powerful institution for raising living standards ever invented: indeed there are no rivals. But markets need states, just as states need markets. In a proper marriage between the two, one has contemporary liberal democracy, incomparably the best way to manage a society.'

Arthur Seldon, for many years editorial director at the Institute of Economic Affairs in London where his partnership with Lord Harris significantly influenced the Thatcher government, authored many fine and some classic works. One such classic was $A$ Credo for Private Enterprise for the New Zealand Employers Federation in 1980. Much of this publication is eminently quotable and like Wolf and Novak he had little doubt about what is the best system: The supreme task bumanity has faced down the centuries has been to discover and mobilise the abilities, talents and genius of individuals in the creation of civilised society. The rationale 
and vindication of decentralised initiative independent of the state, described popularly as 'private enterprise', historically as 'capitalism', technically as 'the market economy', is that it has proved more effective, with better results in living standards than any other system from the mixed economy of social democracy to the centralised planning of communism' (:pages unnumbered). He emphasised that the freedom to choose and fail, and the freedom to succeed at the level that each wishes, is encouraged and supported by a subtle process of incentives which may be financial reward, or more intangible like the care and love of family.

Youkins (2001), Professor of Accountancy and Business Administration at Wheeling Jesuit University, provides further insight when he explains that the capitalist system enables individuals to pursue their own goals, and that the role of government is to allow that pursuit of happiness. 'Happiness', he states, is the positive, conscious, and emotional experience associated with the use of a person's individual buman potentialities including one's talents, abilities and virtues. Happiness (and dignity, self-respect and self-esteem) cannot be given to people; it must be attained through one's own exertions.' Governments can only set the scene.

Novak (1991) with brilliant insight identifies democratic capitalism's 'ironic flaw'. The greater the political and economic successes, the more they are likely to 'undermine it in the cultural order' (:31). Thus, the very seeds of democratic capitalism' success serves also to generate distrust and even hatred. 'Capitalism is associated with selfishness, exploitation, inequality, imperialism, war' (:31).

John Paul's (1991: Centesimus Annus) warnings that 'ultimate truths' must 'guide and direct' if the elusive ideals of the 'free and virtuous society' are to be achieved, again reflect the tensions between man's agendas and these ideals. The rejection or ignorance (whether deliberate or a blind pursuit of personal agendas to the exclusion of others' dignity, needs and rights) of these ultimate truths lead inexorably to conflict. 
Novak provides a list of reasons why these conflicts occur to which it is not difficult to add others. There is almost a supermarket of prejudices that are frequently, often daily, played out on our living room TVs. On almost any given day you may choose from the list in front of you: excesses of wealth, poverty, abuses of the environment, Novak's 'corruptions of affluence', envy, alienation exacerbated by distortions in the ownership of material goods, and an emphasis given to the inane and unimportant (for example, the lives of sportspeople and movie stars). Indeed, the list is often so powerful and disturbing that questioning whether there is a better way is inevitable.

Individual freedom creates both strengths and weaknesses. By flowing with the tide of human nature, it allows great originality, the entrepreneurship that is the lifeblood of business. Freedom allows choice but it does not necessarily create virtue and morality. What is virtuous and moral can be a matter of choice and opinion. And since each person, under democratic capitalism, is free to choose, the menu of choice is as endless as the human spirit. But when one person's preference has the potential to be another's opposition, the opportunity for conflict is also endless, were it not for the boundaries imposed, or suggested, by moral norms, and the rules and processes established by the majority but accepted by all.

Thus, it is not surprising that Novak also insists that '...the moral-cultural-system is the chief dynamic force behind the rise both of a democratic political system and of a liberal economic system' (:185) and in it lies its weakest link. The justification for that strong assertion is in the war of ideas and beliefs.

It is difficult, if not impossible, to contain in a definition all that the moralcultural system includes, for by its nature it is amorphous and fluid. Certainly it is about ideas and beliefs, values, and what is right and what is wrong. Certainly it includes family, churches and religions. But it is also about the arts, social and educational institutions, and the attitudes, behaviour, and 
customs of a people, race or community. Cohen (1985:20) suggests one view of culture is that it is something held in common by members of a society.

Freedom of speech is a basic right under democracy. Many political ideologies have a strange and sometimes fatal attraction as the world found out with Hitler in the 1930s and1940s. But that is an extreme example. As any parent quickly finds out, too much freedom and too little discipline creates chaos and conflict for families. A parent saying no, and having that respected, is critical for the well-being of the child (and the parent). So it is so for societies. Too much licence will crumble a society from within, as history records. Selfgovernment is not possible without self-discipline' (Novak, 1991:168). Vast individual liberties inevitably mean the sacrifice of some order. As Henry Grunwald, then Editor-in-Chief of Time Inc, noted in 1983, freedom does not come without pain.

Therein is the dilemma. Societies with high levels of freedom to express their ideas, follow their beliefs, pursue an entrepreneurial business... also have great vitality. Yet, heed of Gardner's advice is also essential. Where principles and values are lost or set aside, perhaps for popular causes, society runs the risk of decay from within. Novak (:186) states that belief this way: Democratic capitalism is more likely to perish through its loss of indispensable ideas and morals than through weaknesses in its political system or its economic system'. Robert Maynard Hutchins, educator and long-time President of Chicago University, voiced a strikingly similar view: The death of a democracy is not likely to be an assassination by ambush. It will be a slow extinction from apathy, indifference and undernourishment. ${ }^{28}$

The implications these views have for community enterprises is that the weaker the moral-cultural order, the greater is the potential for decline, and thus the more 'gaps' in society. For if communities have high levels of trust, respect for each other's rights, and a high level of care and support, then

\footnotetext{
28 This quotation from Hutchins (1899-1977) was noted by the writer almost 20 years ago but the date and the occasion of the speech was not recorded. It is likely to be a speech published by Vital Speeches.
} 
problem areas will undoubtedly be less. The social capital debate, discussed later in this chapter, is predicated on this belief. Fukuyama (1995:7) stated it strongly: '...one of the most important lessons we can learn from an examination of economic life is that a nation's well-being, as well as its ability to compete, is conditioned by a single, pervasive cultural characteristic: the level of trust inherent in the society.' 'Trust is aided by principles: acceptance of the dignity and rights of each person, tolerance of their choices (except where those choices are destructive) and support for those in need.

But because democratic capitalism is a trinity of systems, it is also true that where a free market and liberal democracy are not well developed, community enterprises may here too have a strong role to play. Why and how that may occur is developed in what follows.

It is as well now to contextualise these discussions in the phenomenon of globalisation.

\subsubsection{A GLOBAL AGE}

The word 'globalisation' has 'considerable emotive force' (International Monetary Fund, 2002). It is a modern term ${ }^{29}$ in its interest and impact ${ }^{30}$ that often creates some extreme views. At one extreme it manifests itself in the riots and protests of the anti-globalisation movement of the late 1990s and the early 21 st century, and a longing for the mythical simplicity of past times; and at the other, an advocacy for borderless nations for trade. None can doubt that in a few short years, and certainly less than one generation, the impact of globalisation has been major.

Significant falls in the cost of travel and great technological advances in communication are factors in the advance of global markets but its impact is

\footnotetext{
29 Although, arguably, not modern in concept (Bordo et al, 1999).

30 A web search via Google identifies how common is its word use - over 33 million hits (as at March 2006).
} 
greater than those aspects, important as they are. Giddens (2001:3) defines global impacts as being 'political, technological and cultural as well as economic' and quotes (1999:4) sociologist Daniel Bell: '... the nation becomes too small to solve the big problems, but also too large to solve the small ones' as one example of a (perhaps) extreme view that has a semblance of truth.

Martin Wolf (2004) in his detailed and balanced critique refutes that. He provides a series of definitions of which the most penetrating is also the longest. He quotes from Brink Lindsey's Against the Dead Hand: globalisation should be seen in three distinct but interrelated senses: first to describe the economic phenomenon of increasing integration of markets across political boundaries (whether due to political or technological causes); second, to describe the strictly political phenomenon of falling government-imposed barriers to international flows of goods, services, and capital; and, finally, to describe the much broader political phenomenon of the global spread of marketorientated policies in both the domestic and international spheres. Since I contend that globalization in the first sense is due primarily to globalization in the second sense, and that globalization in the second sense is primarily due to globalization in the third sense, I do not think it unduly confusing to use the same word to mean three different things' (:14-15).

Giddens (1999:5) quotes but disputes a pessimist's view of globalisation as 'destroying local cultures, widening world inequalities and worsening the lot of the impoverished...creating a world of winners and losers, a few on the fast track to prosperity, the majority condemned to a life of misery and despair.'

That pessimism, and Bell's view, would seem unduly extreme and in all probability, is significantly incorrect. A different view is that offered by the International Monetary Fund (2002). The authors point to evidence that where countries integrate into the global economy through a variety of policies $^{31}$, faster growth and reduced poverty occurs. They compare the

\footnotetext{
${ }^{31}$ As Stiglitz (2002) notes in his criticism of the so-called 'Washington consensus' failings in their policies for the 1997 Asian currency crisis, that there are no absolute formulas but experience has taught that some policies are better than others. The phrase, Washington consensus, coined in 1990 by John Williamson, senior fellow at the Institute for International Economics, was originally intended to describe policy advice by Washington-based institutions which included (inter alia) fiscal discipline, tax
} 
inward-looking policies of the stagnated or declining economies of Latin America and Africa with the tremendous growth comparatively of East Asia. They acknowledge that progress is uneven and there are risks.

John Norberg's (2003) production for UK's Channel Four, 'Globalisation is Good', illustrates the comparative performance of two countries equally poor 50 years ago, Taiwan and Kenya. Today Taiwan is twenty five times richer than Kenya'. Wolf (:4) is equally supportive: 'The failure of our world is not that there is too much globalization, but that there is too little. The potential for greater economic integration is barely tapped. We need more global markets, not fewer, if we want to raise the living standards of the poor of the world.'

The opponents to globalisation, reflected in the extensive literature, are many and varied. It is as well to review some of their arguments and concerns for their insights into the deficiencies of the prevailing world order, and the lessons they may advance.

Wolf (2004:6-8) provides a useful summary and categorisation of the opponents:

- Conservationists and environmentalists concerned with further damage to the environment;

- Consumer groups fearful of poor product safety and consumer health;

- Human rights groups, particularly those adverse to the exploitation of cheap labour in developing countries;

reform, interest rate liberalisation, a competitive exchange rate, trade liberalisation, privatisation, deregulation, security of property rights, liberalisation of inflows of direct foreign investment and prioritising public expenditure towards such fields as health care, primary education and infrastructure.

There is contention that such a consensus exists, but not that the above list of policies will deliver greater wealth and reduce poverty. There will always be contention as to how, and what degree, these policies are implemented in the particular circumstances. 
- Church groups and

- Other groups concerned for societal sectors that cope poorly with the rapidity of change associated with globalisation;

- Campaigners for indigenous groups and traditional ways of life;

- Socialists and neo-marxists opposed to capitalism;

- Anti-liberalists with 'old preferences for the comforts of community over individual striving, for traditional ways over rapid, for the beneficence of the state over the cold logic of the market, for collectivism over freedom and for the nation over the global economy'(:7).

Clearly the list encompasses so many that Wolf quotes journalist John Lloyd (2001:21) that often the only commonality between opponents is their rejection of Western/American capitalism, the oft-derisive allegation of the McDonaldisation of the world.

Wolf, in discussing the failings of democratic capitalism, asserts that the 'reason for rejecting most, though not all, of the charges of the critics is not that the world is perfect, but that it would be worse if they had their way' (:11). He believes the major problem is not economic integration but 'political fragmentation' (:12). If we want a better world, he counsels, we need better politics.

Globalisation's impacts have particular significance for the role and influence community enterprises may play in these ways:

- Since the market economy and the structure of private ownership are the vehicles of delivery for the great improvement in wealth and reduction of poverty that has occurred in the last twenty-five years, what is the need for community enterprises? Or is Fukuyama (1995:17) approximately correct in his 80\% scorecard for free-market 
economics, thus inferring a greater need than previously accepted over the latter part of the twentieth century for complementary structures? The opening quotes from Giddens, Stiglitz and Putnam all refer to a need for new and reconstructed institutions.

- Does the inevitability ${ }^{32}$ of globalisation create circumstances where communities, to protect their interests (which may be a way of life they love), need to put in place structures that complement private enterprise?

- What are the weaknesses of the global market economy that need to be addressed? ${ }^{33}$

Wolf's lists of opponents and criticisms are significantly generic and need to become more specific if answers are to be provided to these three questions.

Shore is helpful. He believes 'the paradox of our time is that while wealth is being created at unprecedented levels, it is not reaching those in greatest need. If anything, it has created a complacency, a comfort with the status quo, an assumption that a rising tide will lift all boats. The tragedy is that prosperity also hides poverty' (Shore, 2001:50). A social entrepreneur of some fame, Shore founded Share Our Strength (SOS), an anti-hunger and anti-poverty organisation. He examples that today one in four children under the age of three in the United States lives in poverty and in a single parent home, and that nearly one quarter of all pregnant women receive little or no prenatal care.

So also is Gates (1998) helpful. While not unrealistically expecting for all to be equally endowed, he gives emphasis to the extreme degree of inequity that he

\footnotetext{
32 It is difficult to see that much of the forces driving globalisation are reversible, or even that, if they were, that the majority of people would desire to do so. For example, the ease and cost of international travel, instant access to international events and the internet are desired by significant numbers, as reflected by usage.

33 Shore (2001:213) alludes to weaknesses: 'It is both the excesses of capitalism and the gaps that exist in a freemarket economy that have left many people bebind in our country.'
} 
insists occurs through capitalism. He believes ownership benefits flow disproportionately to a few, a statement he supports with often startling statistics. For example, he quotes a United Nations 1998 estimate 'that the assets beld by the world's 225 richest people exceed the combined income of the world's poorest 2.5 billion people' (1998:7), and that the share of wealth owned by the richest 1\% Americans has risen from below 20\% in 1979 to 38.5\% in 1995.

Gates believes these distortions are the fundamental source of disharmony and conflict in society and result in a 'disengaged citizenry' through capital being given a primacy: 'Contemporary capitalism is not designed to create capitalists, but to finance capital' (:xix). His solutions are many and include the reconnection of personal conscience to market capitalism thus better ensuring economic decisions are made with sensitivity to the community. He would reinvent and reengineer capitalism to extend ownership to a much wider base of society, while cautioning against too radical change too quickly: fine tuning is necessary, not new systems of order.

Korten (1995), too, would seek change. There is a need, he believes, to move beyond the present economic model with 'its imperatives of the money world. The buman future depends on finding more bolistic approaches to dealing with poverty, unemployment and social disintegration that give priority to meeting basic needs, restoring the bonds of community, and healing the planet. The idea is not to exclude the market or productive enterprise, but rather to assure that their function is consistent with the principles of equity, sustainability, and civic engagement' (:3). He seeks preference for smaller, locally owned enterprises. Notably, some communities are banning chain groups from locating in their area; others are containing the size of megastores with area restrictions (Mitchell, 2002; Imbroscio et al, 2003). ${ }^{34}$

\footnotetext{
${ }^{34}$ It should be noted that such actions themselves can cause distortions and are likely to be an imperfect and perhaps extreme reaction. A better and more balanced solution to the domination of a major business within a community is to encourage smaller, locally owned businesses. That encouragement could be through beneficial and supportive town planning, which often occurs now for major corporations when cities compete for location of plants with attractive economic packages: for example, see Shuman (2000:1-3).
} 
Shuman (2000) is also an advocate of 'Going Local'. The global rush to free trade has 'blurred distinctions between communities... and dulled people's sense of place' (:14). He advocates communities seeking to be as self-reliant as possible and offers as one suggestion the model of a corporation with (some) residential restrictions on ownership.

And finally, in this section, Putnam's (2000) plea for new institutions quoted at the beginning of this chapter reflects his conclusions from a mountain of supporting data.

It is as well now, to pull these strands together.

The impacts of globalisation are complex and extensive. Each of the substantive works quoted above, each notable for their scholar and success, portray and evidence that fact. But two themes seem paramount. The first is that global trends are irreversible. They are here to stay and they have brought significant benefits. Countries, communities and individuals have a standard of living and well-being much higher because of globalisation. But the second theme is almost the reverse of the first. It is entirely the order of things that weaknesses follow strengths. And thus globalisation has created much discomfort. The rapidity and extent of change has been dynamic. More people have not coped, more have been passed by, and more distortions have occurred, thus often creating an unbalanced and uneven playing field. The evidence is in the literature quoted, but also all around us.

ALL'S WELL WITH THE WORLD?

A PERSONAL EXPERIENCE

It was the American summer of 1984, and the day had been hot and humid. I had spent quite some hours visiting a number of hotels in New Orleans. It had been a fascinating opportunity to gain more experience in the design and operational management of a range of hotels in the hope that the knowledge gained would help in reappraising the future of our hotels in New Zealand. 
The new Hilton with its spectacular atrium, and others, had been in a different world to my experience. It is hard to describe the awe the hotels I saw generated. The richness of design and décor gave the impression of significant wealth and expense, something I knew could not be replicated in the much smaller hotels I managed. Thus, also, I was disappointed in the knowledge that we could never aspire to the best of what I saw.

Weary of the day I decided to go for a jog in the gathering twilight. I came to a motorway viaduct of some size. What I experienced could not have contrasted more with the day. For, as far as the eye could see in both directions was a cardboard city under the viaduct, well populated and of some permanence. I stood for some time and watched, again in wonder, this different world.

\section{SETTING THE SCENE: A SUMMARY OF VIEWS}

The prevailing world order today is based on democratic capitalism, which itself is underpinned by the individual freedom to pursue happiness, and expect justice. A predominantly market economy supported and sustained by democracy must themselves be nourished by a moral-cultural system 'buttressed by the mediating structures of family, church, and other voluntary institutions' (Younkins, 1999:3). Equality of opportunity is the ideal result sought for all, but equality of outcome is not a reasonable expectation. Levels of wealth and status will always vary greatly under democratic capitalism. Talents, skills and enthusiasm will rarely be equal. Thus distortions under such a system are inevitable. Gaps of inability to cope, alienation and exclusion will always occur and it is the role of the family, community and the state to address these issues, generally under the principle of subsidiarity discussed later in this chapter. It is not desirable, however, if the distortions and gaps are such to create undue societal conflict. What is undue may be contestable (for there will always be some who will be envious and greedy and not inclined to seek their own free and fair remedies) but where the prevailing systems generate manifest unfairness, society should seek to better balance the rules of the game. 
The role of community is no less contentious an issue than the market economy and globalisation. It is to this that this dissertation now turns. For while democratic capitalism is founded in freedom and the individual, the irony is that without association in community, humankind can not achieve its full potential. Community is the nuts and bolts and glue that hold Novak's tripod together, thus ensuring it works.

If it is true that alienation is the pathology of this age - an assertion voiced in different ways by many people, for example, Gates (1998), Putnam (2000) then new and renewed forms of community association are essential.

\subsubsection{THE NEED FOR COMMUNITY}

The community stagnates without the impulse of the individual, the impulse dies away without the sympathy of the community'.

William James

At times the debate and contradictions of community are almost hopelessly complex. It is one of the most analysed words in the English language. It is ironic that while by definition it refers to the wider 'we' or group, community is essentially individualistic. Its nature is symbiotic with community enterprises. These and related concepts will be explored in what follows: in particular, the nature of, and 'thirst' for, community; and the impact of culture.

Fowler's (1991) detailed and fine analysis in 'The Dance with Community' explores many of these complexities. In believing that 'community goes deep into our souls' he suggests that this process 'belps us to understand ourselves in quite (but far from exclusively) rational terms. For its denizens community must be seen, chosen and experienced. Indeed, it really is 'shared self-understanding of the participants' (Sandel, 1982). A common life is crucial, but it is not sufficient. A shared life, self-consciously accepted, is required (Hillery, 1955).' 
A shared life, but today that sharing is much different in its totality from the 'warm feelings' that the image of community instinctively generates and attracts. That image is of the best of our times past where we are drawn to simplicity and happiness, often of our childhood. But while these feelings are replicated from time to time it would be wrong to infer they present an image that is entirely representative of community. Fowler talks of an 'existential model of community' which emphasises 'paradox, tension, even contradiction. Those intrigued by it muse about the possibilities of expanded individualism as well as expanded community, about a shared culture filled with free minds, and about democracy and authority bonded together' (:155).

The idea that community is individual in its essence is further explored by Fowler (:155): 'What matters ... is the individual who nourishes community, who thrives in community, the person whom community creates. The individual is the story in community, not in isolation to be sure, but not homogenized and destroyed by absorption into a character-denying community either.'

Today there is so much choice as to what community each may seek. So much so that we jump in and out of community as we desire. It may be sporting, religious, art or our need for company or reassurance. That choice is individualistic, yet in choosing, we benefit not only ourselves but also, providing the contact is positive ${ }^{35}$, those with whom we associate - Donne's famous 'no man is an island, entire of bimself' and de Tocqueville's (1969) 'selfinterest rightly understood' which as Younkins (1999:7) explains is the 'idea that man serves himself when he serves his fellow human beings.'

Fowler again highlights the complexities:

\footnotetext{
${ }^{35}$ Community association may, of course, be negative, even destructive. Berger (1998) believes its dark side-'alienation, anomie, and powver struggle(s)' is most often ignored, particularly by the advocates of community. Further, in believing the concept of community is overrated, he warns that 'cultural modernism' supports 'limited, partial, segmented... shallow commitments' which, while perhaps allowing greater freedom, also increases alienation through a fickle sense of belonging. Community can also be used to exclude, for as Portes and Landolt (1996:3) note 'the same strong ties that help members of a group often enable it to exclude others'. Examples are Italian, Irish and Polish immigrants in the United States,
} 
'Above all, there was our ability to love - and thus to strive for community. ... Such was the goal, understanding that every experiment to realize it was, of course, always promise, always in process, always partial. ... Everything filtered in between a false dualism. Community could not be nourished in an individual-denying world or in a naively individualistic one, not in an irrational world or a nonmysterious one, not in capitalism or socialism. It could grow only where dialogue and openness sprouted. It had to be realistic and respond to pragmatic imperatives - including the communal. And, of course, community bad to be chosen by each person...chosen in both faith and uncertainty, belief and risk' (1991:157). And that is why community is so difficult to understand and to define. It is intertwined with our thirst for life, truth and love which, as Sheen (1955:13) tells us 'are not to be found in this life in their completion'. Catholic social teachings insistence on a higher order of influences (for example, see Centesimus Annus (1991:49-51) have parallel themes.

Fowler's scholarly approach to community, while giving important insights, needs to be translated into pragmatic imperatives for it to be more meaningful to an understanding of community enterprises.

Community can be a place and for most, that is how they would describe it. A person would identify themselves as belonging to a country (for example, New Zealand), town (Masterton) and, reflecting even more the need for identity, to be individual, thereby enhancing a personal sense of belonging and thus well-being, from an area or neighbourhood (Homebush). Each description, New Zealander, living in the Wairarapa and from Homebush can be used collectively or separately but in all cases, they define.

Cohen's $(1982 ; 1985)$ work is helpful in extending our understanding. In his 1985 oft reprinted publication he based his explanations around 'use'. Use (1985:12) implies that the members of a group 'bave something in common with each other which distinguishes them in a significant way from the members of other putative

and Korean and Chinese groups throughout the world who form an exclusive clan where restriction and regulation of individual freedom and business occur. 
groups. 'Community' thus seems to imply simultaneously both similarity and difference'. Thus in Eketahuna (see case study in chapter 5) the community was defined firstly by their geography, but even more importantly, by their spirit of community that uniquely distinguishes them from the more (arguably) lacklustre community of Pahiatua $25 \mathrm{kms}$ up the road. As one Pahiatua residing politician noted, a public meeting in Eketahuna will have many more attendees than Pahiatua with five times the population. Cohen (1985:118) well summaries this idea: '...the reality of community lies in its members' perception of the vitality of its culture. People construct community symbolically, making it a resource and repository of meaning, and referent of their identity.'

Community may be of interests - sporting, arts, crafts, culture... the list here can be endless and constantly added to or subtracted from, as the creativity of human effort moves on.

Community can be of values - affection, mutual dependence, trust, respect, mutuality, solidarity and commitment (Edelman, 2000). Families and religions are examples of communities of values but these value words also transcend community. All have an impact on the success of any organisation, community or private. Four related concepts - solidarity, subsidiarity, social capital (the phrase often used to encapsulate a number of these values), and corporate social responsibility - are worthy of further exploration to better understand and position community enterprises in today's world.

And finally, community can be each and all of these. A sporting club can be of a place, reflect that particular interest, and have values.

In short, our love affair with community is instinctive, 'very likely eternal' (Berger, 1998:4) and essential for our growth as an individual. Thus the 'community' of 'community' enterprises will almost always endear and endure.

\subsubsection{ASSOCIATED CONCEPTS}




\subsubsection{SOLIDARITY}

The logic of solidarity underpins, and offers insights into, the notion of community enterprises. It is a powerful concept. The word was brought into popular recognition by the trade union movement that struggled for and achieved widespread change in Poland in the 1980s. The concept's popularity, however, is probably more due to Catholic social teaching, notably John Paul II's encyclical of December 1987, Sollicitudo Rei Socialis.

The concept is powerful because it offers a moral counterpart to globalisation. It holds that all nations and peoples are interdependent and have a common destiny. The obvious example is that one country's exports are another's imports. But the interdependence is much stronger than that. Advocates of solidarity's principles would argue that rich nations have a responsibility to not only help and support poor and struggling nations, they should also be aware of, and not endanger, the latter's culture. Too often, John Paul II asserts, the rich nations insist upon their terms, a form of imperialism. Where instead, a country seeks to develop an enduring relationship based on mutual advantage and trust, both have a much greater potential to benefit.

One writer sees hope that solidarity amongst nations is occurring: '...perhaps in our midst there are the seeds of a different future. One day it may appear that today's struggles for liberation, and for peace, for a defense of the earth, for a spirit of community that transcends barriers of nationality - all these movements inspired by an instinct for buman solidarity - were simply the first draft of history' Ellsberg (1989:xv). It is possible to quote both positive and negative examples that support or reject that view. The aid channelled in 2004 to the Asian tsunami victims may be seen as solidarity in action, but the war in Iraq may be viewed in more than a few quarters as an exercise in protecting vested Western interests, however those countries, predominantly the USA and the UK, may have justified it. 
At a community level, there will always be people marginalised through not having the skills or resource to cope, particularly (arguably) in a market world where, for example, the sheer size of corporations with their global policies and reach is daunting. Individuals and even communities can be of minor consideration when the scale of decision making is very large. The flip side for some can be isolation and despair. Examples can be the person who is handicapped by the misfortune of limited skills, or whole communities when a major employer decides to cease operations. In both these and similar circumstances, the notion of solidarity seeks a commitment to the common $\operatorname{good}^{36}$ on the justification, as Hollenbach (1997:73) contends, 'the results of the use of entrepreneurial skills do not belong to the entrepreneur alone, since the skills bave themselves been received in large part from the community.' ${ }^{37}$

The notion of solidarity may be defined 'as a firm and persevering determination to commit oneself to the common good; ... the good of all and of each individual' (John Paul II, 1987). The European Law service (Eur-Lex) sees the principle as 'the necessary corrective to freedom'. The right and the freedom to hope should be available to all. To achieve that necessarily requires an acceptance of Donne's no man is an island.

\footnotetext{
36 The concept of the common good is not without contention but can be defined as the social systems, institutions and environment on which all depend (thus in commons) working in a manner that benefits all people. Included therein are an accessible and affordable public health care system, effective public safety and security that deliver peace, a just legal and political system, education freely available to all, an unpolluted environment and an economic system fair and freely accessible. The contentiousness comes from the trade offs inevitably required. For example, to enjoy a better atmosphere (clean air) we may have to pay more for a product (for the cost of pollution must be borne by someone), or we may have to forego some of our individual freedom to benefit all as in the circumstances of scarcity of water during a dry summer, or we may have to choose between better education and better health care.

${ }^{37}$ Henry Ward Beecher eloquently phrased it this way: 'If any man is rich and powerful he comes under the law of God by which the higher branches must take the burnings of the sun, and shade those that are lower; by which the tall trees must protect the weak plants beneath them'. The quotation was recorded approximately 20 years ago by the writer but the occasion and date was not. It is likely to be a speech published by Vital Speeches.
} 
While most democratic governments would pursue welfare ${ }^{38}$ policies in support of the notion, community enterprises, other community support organisations (Novak's [1991:14] 'system of cultural organizations moved by ideals of liberty and justice for all') and individuals would do so more through idealistic choice. There are clearly too, limitations on how far the principle can be taken. As Fukuyama (1995:156) notes, capitalism is a process of 'creative destruction' and many businesses and other organisations have a life cycle. If solidarity is taken to an extreme extent, society and communities can be disadvantaged through attempting to sustain the unsustainable. Each individual too, within their limitations, must accept responsibility for their own welfare and development. And the final limitation is perhaps the most pervasive: the degree of commitment by individuals, communities and nations to the concept.

But it would be wrong to infer that solidarity should be constrained to the economic sphere. Solidarity offers much to the ideal of a better world. Philosophically, it explains why community enterprises will be enjoyed and sustained, because they offer a moral and practical outlet for the growth of the giver, and the dignity of the receiver; and because, as Gewirth (1996:6) stipulates: '...every buman has rights to freedom and well-being against all other bumans, but every other human also has these rights against him, so that he has correlative duties toward them.'

TUNISLAN NATIONAL SOLIDARITY FUND ${ }^{39}$

In 1993 the President of Tunisia called for a National Solidarity Fund to be established in support of the principle of solidarity and mutual belp between Tunisians. The fund was to

\footnotetext{
38 Welfare policies may support (as they would predominantly do) but they can also foster dependence and lack of personal responsibility. Effective solidarity should help 'recipients to develop their own abilities of productive agency with concomitant positive effects on their autonomy and sense of personal responsibility.' Gewirth (1996:349-350)

39 The information herein was gathered from web-sites listed in the references. While the details were cross-referenced amongst the sites as must as possible, the commonality of information and language suggested some information had a common source, and that there was a degree of advocacy contained within.
} 
provide help in 'shadow areas' where the State could not because of high cost, thus supporting basic infrastructure construction, for example, drinking water, roads, tracks, health care, providing micro-credit, and eradicating sub-standard housing.

Tunisia is a Muslim country of 9.974 million people bordering the Mediterranean Sea with a GDP per capita of \$6900US, unemployment of 14\%, a life expectancy of 74.7 years, a poverty level of 4\% and 74\% literacy. Many of these indicators have significantly improved in the last 10 years.

In the 11years since its establishment, 240,000 families have been helped at a total cost of 784 million dinars (\$US580m); water has been provided to 81,000 families, and 62,000 housing units constructed, amongst much other support.

While contributions to the Fund are sought year round, December 8 is dedicated as National Solidarity Day. In 2002 2million contributed to the Fund, up from 182,000 in 1994. The success of the Fund has encouraged the Government to start the Tunisian Bank of Solidarity with its 18million dinars (\$US13m) capital subscribed by 200,000 shareholders.

In recent times, the advocacy of the President of Tunisia to the United Nations has seen the concept of the Fund adopted by the general Assembly and a World Solidarity Fund approved.

\subsubsection{SUBSIDIARITY (AND THE NEED FOR FREEDOM)}

It is common to emphasise at an early stage in any discussion or writing on a community structure or partnership, how important is the need for community association if any person is to achieve their full potential, however each may decide that to be (for example, Strike, 1993:11; Peters and Marshall, 1988:658; Fowler, 1991:4). But the need for community, accepting that it is a fundamental need, must be understood in the context of liberalism and the liberal policies that have driven much of the world economy. 
A range of issues could be canvassed, enjoyably and at length, in pursuit of these themes: for example, the debate between liberals and communitarians, or, on another plane, is liberalism receding or advancing in the face of conservatism? While both will be touched upon in what follows, this thesis is not primarily a debate about community versus the individual (although it should be noted for its perspective), nor any need for more community (but that needed to be addressed), nor community enterprise versus private enterprise (but because it is an 'obvious' question of relative justification, it too should be debated), and not who comes first, society or the individual. The theme of this thesis is community enterprises, their constituent parts, and what gives rise to their enduring and endearing nature. Thus, the debates noted above are briefly commented on for their contribution towards these themes, but not pursued to any length. In adopting this approach, the writer acknowledges the many different perspectives and emphases that may be placed, and which may lead others to take a different view of community enterprises' place in the modern world. This writer may wish to debate the value of these views but acknowledges the rights of others to argue their perspectives. The writer's own 'conditioning' is clearly tabled in chapter 1 so that the reader may judge the writer's credentials.

One such debate, which peaked in the mid 1990s, is that between the liberals and the communitarians. Bentley (2003:147) states the respective positions well: The paradigmatic liberal position, articulated by John Rawls in a Theory of Justice (1971) and Political Liberalism (1993), proposes that in order for citizens freely to choose their own beliefs, goals and preferences, society should adopt "justice as fairness" as its organizing principle and government should remain neutral in adjudicating between competing (private) interpretations of the good life. Communitarians for their part take exception to liberalism's abstraction. They contend that liberalism presupposes an impoverished conception of the person and of the relationship between individuals and their social worlds. Communitarians like Michael Sandel, Charles Taylor, and Michael Walzer argue that individuals derive their identities from complex social and familial relationships and that people are deeply imbedded in these meaningful relationships antecedent to choice.' 
The at times intense debates have the potential to obscure the common sense balance that is required in any ordered society : too much individual freedom is arguably just as contentious (for if each of us adamantly and vigorously pursues our [perceived] individual rights, clashes are inevitable) as too much stultifying community association. There will always be movement in a continuum between the two, as extremes bring reaction.

The debate over whether society in the modern world has allowed too much freedom may be seen in the fall and rise (and fall again?) of conservatism as an ideal. Again in a continuum between liberalism and conservatism, where the balance lies at any point in time has relevance to the environment of support for concepts such as community enterprises: in times of liberal-driven philosophies (for example, the 1980s and 1990s when market-driven policies held sway) community and state enterprises had little support in the face of rampant privatisation.

There is another debate which is not contested here. That debate centres around a criticism, often intense, that the neo-liberal reforms implemented in New Zealand are fundamentally flawed (Kelsey, 1995; 2002; Peters and Marshall, 1988). Kelsey, while strongly advancing her own alternatives and preferences (2002:123-5) concedes that 'a realistic approach cannot turn its back on the existence of either capitalism or the international economy.' Curtis (2003) holds a similar view: 'In the New Zealand context, at least, the arguments for a continuity of neoliberal policy are compelling'. That position is accepted in this work. There is, thus, no contention here that radical change to world policies is required. Market forces, privatisation, minimal state interference and democratic capitalism are accepted in this study as being fundamentally right in principle, and when (not if, for there will always be a need and an opportunity to improve) aspects of their implementation in practice are in error or cause undesirable or unacceptable (side) effects, that should not imperil the concepts in their entirety. 
Liberalism requires some definition if there is to be an understanding of the role that community (enterprises) may or must play in the $21^{\text {st }}$ century. For as Strike (1993:14) warns:

'An emphasis on community is inconsistent with liberal individualism when it generates policies or practices that violate these rights and invade the private sphere. The specific character of conflicts between individualism and community in a liberal framework will have much to do with the particular rights people are thought to have and the forms of community to which people aspire'.

COMMUNITIES VOTE TO RESTICT THEIR MEMBERS' CHOICES. AN ABUSE OF FREEDOM TO CHOOSE, OR COMMUNITY WELLBEING?

\section{THE CASE OF LICENSING TRUSTS}

The conflict that can occur between community mandate and individual choice is evidenced in local government today where local democracy is frequently strident and confrontational. It is also reflected in unique citizens' polls in four New Zealand communities.

Licensing Trusts were first legislated into existence in the 1940s. Community owned, they were given a mandate, solely in most areas they were established, to provide licensed bars, restaurants, hotels and bottle stores. As more liberal and competitive regimes arrived in the 1980s and 1990s, their sole rights in their defined communities began to be more attractive and thus came under pressure from competitors, particularly supermarkets. In 1989 under new legislation, communities were given the option of voting to open their areas to competition. In 15 polls since then nine communities have voted to do so and four (one twice) have voted for the status quo.

In effect these polls decide the level of licensed competition within these often large communities (for example, Invercargill and Waitakere cities). Supermarkets are not allowed to trade in beer and wine until a poll of citizens by majority so approves. 
Thus there remain four communities in New Zealand where the majority decide, inter alia, whether the convenience of beer and wine in supermarkets is able to be enjoyed by an individual. ${ }^{40}$

Strike argues compellingly that individuals should have the bounded freedom to pursue 'their own fundamental convictions'. He gives the example of religious belief. Under liberalism, a State cannot assume to advance one set of beliefs over another. Thus, 'much of a community's moral life must be privatised'. Yet a State must hold that some things are right and some are wrong; for example, a right to life, a right to own property and that retribution for a crime shall not be decided by the individual aggrieved. Thus it seeks through a power granted by the majority and accepted by all, to promulgate just laws. What 'liberal individualism insists on is not selfishness' but 'the right to act, uncoerced, on one's own choices and convictions within the bounds of justice' (:16).

Thus the right to freedom of choice is a bounded right. In the case of religion that freedom is a need: that is, the State cannot assume a power it can not have. But elsewhere there will frequently be a requirement to balance the individual's right with the greater good of the community. An example would be that the individual's right to own property is not an unfettered right. A farmer may be required, for example, to bridge or fence a stream or river to reduce pollution caused by animal use.

Gronbacher (2002:3-5) presents a different but complementary perspective. In asserting that individuals should always be respected for their dignity politically, socially, culturally and economically, he defines the ideal of a humane economy as one that is 'able to produce an abundant amount of wealth...justly'... where 'the processes of ...the entire economy would be open - resisting the erection of barriers to entry based on unjust discriminations. Wealth would be put to constructive use to benefit the greatest number of individuals. And finally, that those who cannot participate in creative enterprise will maintain some sense of self-sufficiency and be

\footnotetext{
${ }^{40}$ The issues are summarised here. For a more detailed analysis see chapter 6.
} 
provided for through charity.' He is consistent with previous paragraphs when he maintains that economic liberty best delivers such a humane economy.

One aspect of economic liberty is the need for government controls and involvement in the markets to be restricted to those that ensure fairness and justice. 'A strong juridical framework is required for the markets to operate effectively' but 'excessive taxation, reckless government monetary policy, unnecessary barriers to trade, ineffective safety regulations, complicated and unfair employment policies, and expensive licensing requirements' are not (Gronbacher, 2002:5). Novak (1991:14) emphasises the need to limit the power of the State so as 'to liberate the energies of individuals and independently organised communities.' In an essay titled The Crisis of the Welfare State (1999:84) he compellingly argues that 'the achilles heel of social democracy is that it cedes too much responsibility to the collective' and that 'social democrats not only tend to over-emphasise community, but also too uncritically to identify community with the collective' thus choosing to enlarge the role of the state. The benefits of the welfare state become too attractive and lull people away from individual responsibility.

The principle of subsidiarity flows from this and needs to be understood in aspiring to an ideal society. A government, to whom the principle is most commonly applied ${ }^{41}$, should not presume to provide help (subsidium) which the individual or community is best to perform (Hollenbach: 1997:73-74). Thus, a community enterprise should not attempt, in pursuit of this principle, to assume responsibilities that are more properly the individual's ${ }^{42}$. The law of unintended consequences ${ }^{43}$ can also apply in that the best intentions of the State may deliver the opposite, generally summarised as a lack of incentive to

\footnotetext{
41 But this principle has much wider application. As Novak (1991:178-9) records, its relevance is particularly effective for corporate management: decisions should be made at the lowest level appropriate to implementation. Peters and Waterman (1982:250) give a powerful example in their chapter 'Productivity through People'. '... the most important people... are those who actually provide a service or make or add value to products... That is, when I am in your 25 square feet of space, I'd better listen to you!'

42 Lord Blackwell's (2001) lecture provides a fine treatment of the issues.

43 Adam Smith and Friedrich von Hayek are credited with the first explanations of this law.
} 
take personal responsibility and an increase in state agencies, bureaucracy and spending without necessarily solving the problem being addressed.

But therein lies the difficulty. It is relatively easy to understand the principles. It is far more complex to implement in practice. The balance between the need for individual freedom and supportive community and government structures is always going to be a moving target. There are far too many contributing factors for it to be anything else. Not only will the balance of need vary for each individual, perhaps not significantly but finely so, it also can and will vary at different times during a person's life. But, John Paul II insists: '...political leaders, and citizens of rich countries considered as individuals... have the moral obligation...to take into consideration...this relationship of universality, this interdependence which exists between their conduct and the poverty and underdevelopment of so many millions of people' (1987:9).

In 1988 in two essays submitted to the Royal Commission on Social Policy in New Zealand Peters and Marshall argued that the rights of the individual had been taken too far. In maintaining (and quoting from Treasury documents, 1987:401,405) 'The individual is seen as 'the most important element in promoting welfare' and the 'well-being of individuals' is regarded as 'the logical starting point for an analysis of social policy" and that 'the driving force of the logic behind Treasury's' adopting that position 'is, theoretically to exclude any fullblooded notion of community and to view welfare and social wellbeing as a product of individual choice and contract within a free market economy', they held that 'such a view is philosophically untenable, intellectually impoverished, and will prove to be inimical in the long term to the larger interests of New Zealand society.' Policies were needed, they argued, 'to encourage and support' existing and new community initiatives, otherwise increasing levels of crimes and racial conflict will arise.

Some rebalancing towards a more inclusive society has been a theme of public policy and politics ${ }^{44}$ in recent years, and as Kelsey (2002) notes, has

\footnotetext{
${ }^{44}$ For example, as reflected in the Third Way movement (Giddens, 2001; Latham, 2001).
} 
been occurring in New Zealand at least in the rhetoric since the election of the 1999 Labour-led Government.

Recent political utterances give some leads where the balance of emphasis between individualism and community/state lies in a continuum between the two. It is of relevance to this work because an understanding better defines the climate of acceptance for community enterprises as well as the resources that may be available. The 2002 support for social enterprises by the British Government and the growth in not-for-profits (Shore, 2001; Porter and Kramer, 1999) suggests there is more positive receptivity than in years past. Larner's (2004) paper on neo-liberal theory and practice in the particular context of the Stronger Communities Action Fund pulls together some of the strands of the last few paragraphs. She quotes Prime Minister Clark's 2002 address that neo-liberalism in New Zealand is now over but while the rhetoric may suggest some distancing from the policies of the 1990s, and Third Way policies pursued, her view (2004:19) is that what may be emerging is 'a more pragmatic political accommodation' targeted more specifically towards defined needs rather than universality of application.

Larner offers two further views that have applicability to community enterprises. While suggesting like others (for example, Shuman, 2000; Gates, 1998) that local solutions seem to be more in vogue, she notes: 'Ultimately the aim is to increase opportunities for individuals and communities to construct and transform their own ways of life, to build self-esteem and empowerment. Once individuals and communities become 'entrepreneurs of themselves', there is also the possibility they may also become an entrepreneur in the more conventional sense, with the corollary that social development will lead to economic development'.

The second line of thought has relevance to the enterprise attributes (for example, entrepreneurship and the generation of profit) that community enterprises require to survive. There is, she suggests, (:16) a greater movement of people between different sectors, which Shore (2001:137) also reinforces, 
with one result that 'categories of state, market and civil society are increasingly problematic'. Thus, for example, management skills acquired in private enterprise, will more likely to be seen as more acceptable and relevant for the 'not-for-profits' world and community enterprises. It will be more attractive for managers to readily transfer between sectors.

\subsubsection{SOCIAL CAPITAL}

The concept of social capital, given prominence in recent years by Putnam (2000), but not originated by him, is of relevance to community enterprises if it can be shown that they help create, or contribute to, a better society.

At first glance the theory would suggest they should logically do so. Community enterprises seek to address social goals to improve the well-being of a community, and they seek to do so by creating wealth. But relevancy has a number of components, not the least of which is what structure is the most efficient to address the particular issue.

What does the social capital literature offer? It would be wise, firstly, to note its limitations. Whereas financial capital has a universally accepted unit of measure, human capital ${ }^{45}$ and social capital do not. For both the latter two terms there are significant difficulties in definition and deficiencies in measurement. While the latter does result from the former, it also stands alone as a difficult problem. For if we can not measure competently, how is it possible to define progress thereon?

'Originally, the concept of social capital was nothing more than an elegant term to call attention to the possible individual and family benefits of sociability. That usage is entirely compatible with a nuanced understanding of the pros and cons of groups and communities.

\footnotetext{
45 A discussion on human capital (which would be a task on its own of considerable magnitude), while fascinating in its complexities and insights into the ideals of a better life and a better society, is not appropriate for this work, other than peripherally as, for example, through the influences of Catholic social teaching. But it would be relevant to note that these terms - human, financial and social capital have a significant degree of inter-connection.
} 
Unfortunately, that understanding is absent from the spate of recent articles that seek to popularize the idea and make it a basis of policy' (Portes and Landolt, 1996:5).

Hanifan (1916:130), as quoted in Putnam (2000:19), the originator of the term, referred to social capital as '...those tangible substances [that] count for most in the daily lives of people: namely good will, fellowship, sympathy, and social intercourse among the individuals and families who make up a social unit...'

Portes and Landolt's somewhat tart comment ['The intellectual exercise of dressing up common knowledge in fancy language tends to end up as a sermon'(:5)] on Putnam's original work before the release of his extensive treatise in 'Bowling Alone', has been mirrored elsewhere and notably Ladd (1998:3) rejected Putnam's central thesis that we are socialising less often. Ladd asserts that 'social capital is crucial, and it (is) undergoing major changes in its expression. But at the same time, the record shows that overall we're building up our supply of social capital, not depleting it.'

But Putnam's work is deserving of serious study. Notably, as Putnam recorded (:509), his work and thesis was accepted resoundingly by the general public 'because it rings so true to their experiences'. In the latter part of the $20^{\text {th }}$ century significant participatory fall-off has occurred in many of the traditional organisations (for example, Parent Teacher Associations, traditional churches) but Ladd explains those changes as compensatory, that is, new organisations have replaced them. Whatever view is taken, Putnam's work is monumental and many of its themes are not easily rejected. For example:

- The decline in social trust, more so in the young (:140).

- The growth of depression - attributed to 'rampant individualism' and the 'weaken(ing)' of 'our commitment to the larger, traditional institutions (religion, country, family) of our society' (:264).

- A fall-off in a sense of belonging (:275). 
- The impact (that is, on falling civic and social participation) of global economic transformations on community life' (:283).

- A decline in life satisfaction (:334).

Putnam attributes (:283) these declines to 'pressures of time and money' (10\%), 'commuting and sprawl' (10\%), 'TV' (25\%) and 'generational succession' (50\%). He urges 'a great awakening' (:409) and 'new institutions' to replace those no longer satisfactory or appropriate to this age. In the latter he is mirroring Giddens (see opening quote, this chapter).

Fukuyama (2000:6) notes what most would know but take for granted: that association based on 'informal norms' will always be important and arguably more so as society becomes more complex. He presumes also that 'an abundant stock of social capital... produces a dense civil society', a necessary component for today's democracies. Another way of presenting that line of thought is to recognise how many problems disappear when people are able to talk, and, importantly, listen to each other.

Our common sense tells us that strong civic and social ties offer benefits, for example, inclusion, a sense of belonging, self-worth and purpose; but again, as with liberalism and the rights of individuals, there is a balance. Taken too far they can also exclude, alienate and blunt initiative through an overly strong adherence to social and community norms required as a badge of entry.

John Paul II well sums one of the dilemmas of modern life: 'This then is the picture: there are some people - the few who possess much - who do not really succeed in 'being' because, through a reversal in the hierarchy of values, they are bindered by the cult of 'baving'; and there are others - the many who have little or nothing - who do not succeed in realising their basic human vocation because they are deprived of essential goods' (1987:28).

\subsubsection{CORPORATE SOCIAL RESPONSIBILITY}


It is relevant to question the need for community enterprises if private enterprise can provide what the former may seek to do, with the largely proven inference that private enterprise is more efficient in operating businesses (which may be reasonably inferred from the everyday evidence around us ${ }^{46}$ and which is reflected in the structure of business).

To answer that question requires an understanding of the role of the firm and what authority does it have to undertake goals other than profit generation and value maximisation ${ }^{47}$. Once again, this is a topic area, generally labelled corporate social responsibility, where the literature is large and often marked with vigorous defence of both ends of the issue. Some (for example, Kerr, 1996; Barry, 2000) have argued Friedman's (1970:124) view that a business has only one social responsibility, to increase its profit 'subject to the constraints imposed by the 'basic rules of society, both those embodied in law and those embodied in ethical custom' (Barry, 1997:14). Barry (2000:1) goes further: 'Any departure' from the task of providing jobs and products competitively 'is a breach of property and contract rights'.

McCann (2000:1) asserts corporations do have a responsibility beyond a profit but deciding what is a 'notoriously difficult task'. Stakeholder activism has defined, in the nature of conflict resolution, or forced, some issues as businesses seek less painful solutions to bad publicity. But these decisions are hardly a definitive answer to the role of the firm beyond its profit generation responsibility to its shareholders. The state of the debate seems to lie in the

\footnotetext{
46 The privatisation debate is also of relevance but is somewhat of a side show. For the record, privatisation as a policy, while 'widely unpopular' because of real and perceived benefit distribution inequity, (Birdsall and Nellis, 2002:13), has generally been successful, at least as an efficiency tool, in that in $66 \%-80 \%$ of the circumstances (Megginson and Netter, 2001:355-56) where privatisation has occurred, improved economic performance has resulted. Thus the evidence suggests that, subject to a number of important qualifications, private enterprise is the most efficient business structure in most circumstances. At issue in this work is not that private enterprise will generally be more efficient in a competitive business situation but that a non private enterprise structure can successfully (however the participants may so define) operate a business so as to generate wealth to meet its prime objectives.

${ }^{47}$ It is acknowledged that a firm does not necessarily seek to maximise the value it may create [for a treatment of this, see Jensen and Meckling, (1976)] but most businesses would pursue that as a primary aim.
} 
uncomfortable neutrality of Solomon's (1994) 'do no harm' and accept responsibility for the consequences of the firm's business activities.

The practical realisation that few corporations have an expertise beyond their specialty, which itself is pursued to generate profits and wealth, provides an answer of sorts to the opening question. When firms deviate into areas of accepting responsibility for a social ill, they run the very real risk of departing from their prime purpose, and thus adding cost and reducing return. Community enterprises are, by nature, different. They seek to address a social ill by generating business profits.

But, as Lear (:viii) notes in the foreword to Bollier's (1997) stories of socially responsible businesses: There are... scores of socially concerned businesses...Y Yet for many reasons our society does not do enough to recognize such management, explore its distinctive practices or honor its achievements. A great wellspring of social renewal is thus squandered.' The 25 stories that follow are very fine examples of 'bring(ing)...personal values and professional lives into closer alignment' (:3).

This then concludes the setting of the scene for community enterprises. What precedes can only be a broad-brush approach. Each of the section headings are topics on which many authors have pursued complex, opposing, and many shaded discussions and arguments. These are also turbulent times. Change is arguably more rapid than at any time in history. Drucker was typically visionary when in 1969 he wrote The Age of Discontinuity describing the changes that would occur in the latter part of the 1900s.

Turbulent times demand deeper foundations, solid rocks of values and beliefs that will endure. This thesis argues those rocks are the dignity of the person, strong communities enhanced through civic life, and empathetic application of the principles of subsidiarity and solidarity. 
That community enterprises have not only survived these years when the economic and policy climate was rarely supportive at least hints that they are an enduring institution. The renaissance in interest evidenced herein (for example, see chapter 3) suggests that they may be a vehicle able to address some of the shortcomings of today's world order. To advance whether this is so requires an in-depth understanding of the philosophy and theory that contributes to the concept of community enterprises.

The next section therefore develops this framework.

\subsection{A FRAMEWORK FOR COMMUNITY ENTERPRISES}

The definition of community enterprises in the introductory chapter is a starting point. But while that adequately describes what they are and what they do, it does not explain why they should exist, that is, what is their normative justification? To do that requires a stepping back from the component parts of their title, community and enterprise, and considering the individual motivation, for all organisations start with a personal commitment. That commitment may come from one person or a small group of enthusiasts who then motivate others. Such was it so with the Eketahuna Community Charitable Trust in 1989, the Masterton Trust Lands Trust in 1871 and the then New Plymouth Savings Bank (now TSB Bank) in 1850. Such is it so with new organisations today, whether community or privately owned. The starting point is personal motivation. The question that should be answered, therefore, to begin a framework, is what motivates a person or persons to start, work in, or support, a community enterprise?

It is proposed to answer this question by considering some of the literature surrounding self-fulfilment. In particular, Cohen's ${ }^{48}$ work on the Symbolic Construction of Community is heavily drawn upon not only because of its

\footnotetext{
48 His 1985 publication, since reprinted 6 times, was completed while he held the position of Senior Lecturer in Social Anthropology at the University of Manchester. He currently is Professor of Social Anthropology at Edinburgh University.
} 
scholarly standards, but importantly because it beautifully explains why people look to community linkages to provide a sense of identity. That sense of self is thus the starting point which is then extended into a love of community and why that is necessary. The pursuit of solidarity provides philosophical glue to which the attributes of enterprise add practical requirements and limitations, necessarily considered because of what they bring to the concept of community enterprises and for the conflicts they may provide.

The linkages between these aspects may be presented diagrammatically in figure 2.2

FIGURE 2.2

\section{THE COMPONENTS OF COMMUNITY ENTERPRISES}

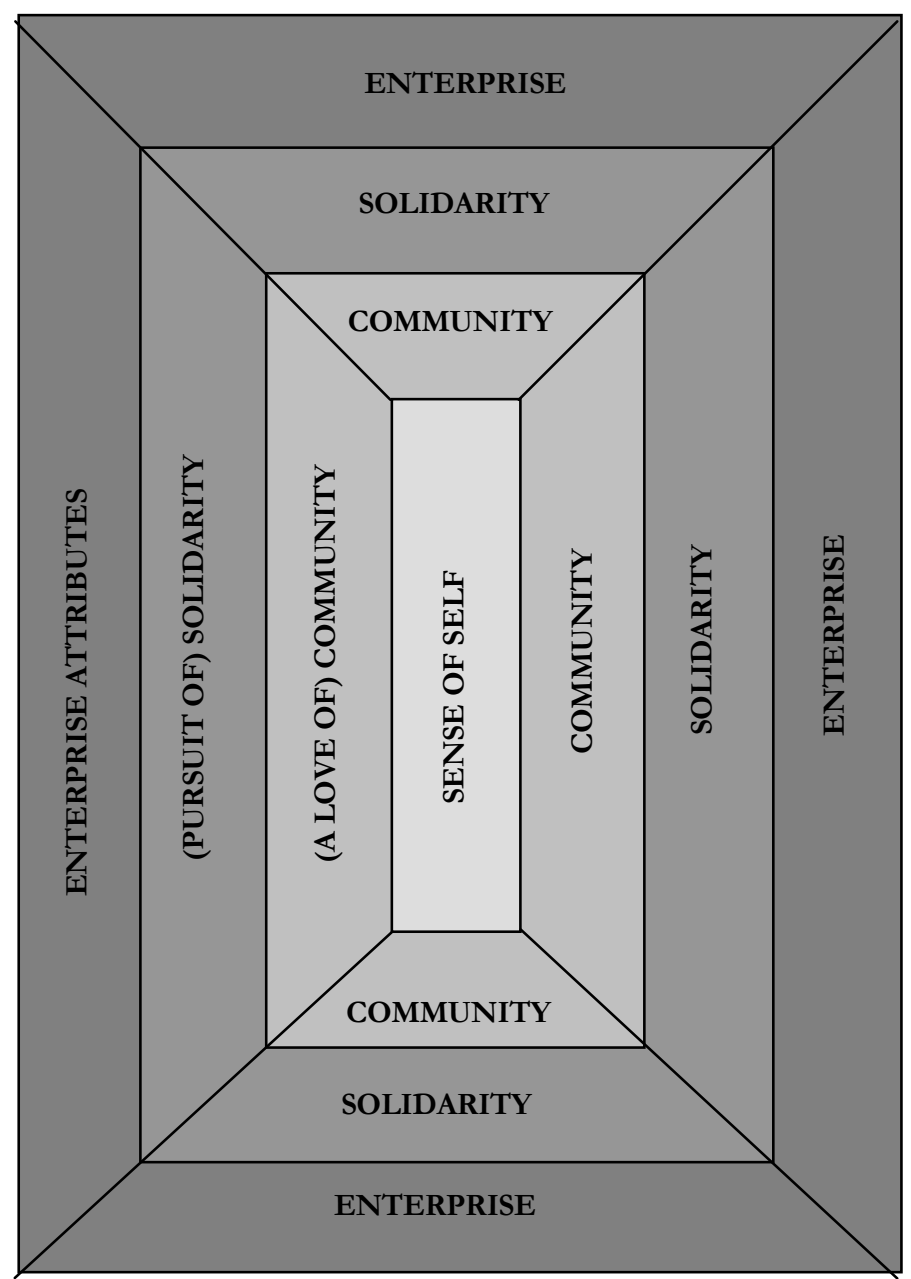




\subsubsection{SENSE OF SELF}

...people assert community, whether in the form of ethnicity or of locality, when they recognize in it the most adequate medium for the expression of their whole selves (1985:107).

People construct community symbolically, making it a resource and repository of meaning, and a referent of their identity (1985:118).

Anthony P. Cohen

In the nature of concentric squares, the shared centre or inner core is the fundamental pivot or essence of the concept of community enterprises. By association that referent of their identity leads, or promises to lead, to a greater sense of self-fulfilment.

\section{A SENSE OF SELF}

\section{THE CASE OF THE LONG SERVING MEMBERS}

What factors would cause two businessmen with diverse and extensive interests in their community to maintain an involvement of over 30 years in their local Licensing Trust? Both occupy senior positions therein and have done so for almost all this period. One has been Chairman/President of the Trust since 1978 and a director of their operating company since its formation in the late 1980s; and the other, deputy Chairman/President of the Trust for over 25 years, Chairman of an associated charitable trust since 1989, and Chairman of the operational company for 12 years. Both assert that financial recompense was never an attraction which is reinforced by its paucity, particularly so in the earlier years of the 30 yearperiod. One of the two admitted in an interview that his involvement has been at a personal financial cost.

The reasons for their high level, sustained commitment are personal and individual, thus supporting Cohen's (1985:107) contention that community association is pursued when it best fits an individual need. 
30 years ago I had a deep personal need to improve myself. I was shy and self-conscious and bad no experience of speaking in public. I needed to bring myself out. It's been stunningly successful. Not so much because of anything I've done, but because of the environment I entered. The reasons I selected the local Licensing Trust was because I had lived in a town where there was one and it had status and the trustees were respected. Thus I knew something about Licensing Trusts and my business skills could also contribute.' (Member 1) I was always very proud of the Trust. My father admired the Trust. When we had visitors to the town we would take them around the premises. Thus we always felt we had a degree of ownership. At that time I was involved in a number of activities, business, civic and church. Many were entrepreneurial. I probably believed (no doubt wrongly!) that I knew what I was doing. I'm proud to be part of the Trust. It becomes part of your life and to walk away is not that easy. Also the job gets easier as you become more experienced. I enjoy (unjustifiably!) the accolades of the successes achieved. The reflected glory is one of the driving forces for me. My pride in the Trust has not diluted over the years.' (Member 2) ${ }^{49}$

It is Cohen's words that inspired the title to this section. Cohen's thesis (1985:50) is 'that the symbolic expression of community and its boundaries increases in importance as the actual geo-social boundaries of the community are undermined, blurred or otherwise weakened' and the excellent case studies he provides in support reemphasise the significance and importance of community. Rather than interpreting society's extensive changes ${ }^{50}$ as homogenising the world order and 'rendering community obsolete' (:117), Cohen asserts that '...the survival, the burgeoning, the assertion of community (is) not... an aberration to be explained, but... a normal, expectable expression of the resilience of culture: of people's sense of self. Simply

\footnotetext{
${ }^{49}$ Both members were interviewed, and the interviews were recorded. Other sources were minute books and annual reports. The themes of the interviews are similar to other recorded interviews undertaken by the author with a number of elected members. The interviews canvassed at some length why community association was chosen ahead, or instead, of other opportunities, for example, civic, sporting or business pursuits.

50 Andranovich and Lovrich (1996) describes these as 'formidable international forces such as the globalisation of the economy, post-Fordist production, ...the advent of an information society linked ever more tightly by advanced telecommunications technologies,... a host of seemingly disassociated post cold-war political instabilities...demographic shifts to shape the condition of community life and contemporary public affairs...quality of life issues, stark gaps between the rich and poor, uneven economic development, immigration pressures and racial tensions.'
} 
put, the greater the fear that something important may be lost, the greater the reaction. The demise of Eketahuna (see chapter 5) and a way of life the community love is an example of how individuals in a community can react to the perceived threat.

People's sense of self is a difficult concept primarily because it is so personal. Yet here is the crux of the dilemma. When that sense is under such threat that collectively alarms, a community will react to protect what it values because, paradoxically, their personal sense of self is so intimately tied to their sense of community. ${ }^{51}$ It is difficult, if not impossible, to separate the personal from the collective. To fulfil our needs, which some may class as inner, Maslow's (1954; 1968) self-actualisation and James' (1961) spiritual, community association becomes important. We strengthen ourselves when we strengthen community association. The reverse also holds true as Cohen (:81; 99; 105) notes. Of course, not all community association will survive and while it is logically fair to say not all needs to nor deserves to, again as Cohen (:104) records, the reasons why some communities react strongly to perceived threats and others do not, are often not clearly understood. Lack of research at local community level may be one reason for this uncertainty. It is, however tempting to point to the obvious, simple and incomplete as it may be: what is allowed to fail may not be valued enough.

Nouwen (1976:137-147) is another author who emphasizes the need for (and inevitability of) community association if a person is to be the best they can possibly be. ${ }^{52}$

\footnotetext{
51 An excellent example of this phenomenon is the lengths a community will pursue to save their hospital. In the early 1990s, 22,000 Masterton and Greytown people turned out to circle their hospitals, to place their hands around, so as to signify to Government the level of opposition to the perceived threat of closure of these facilities. The Government of the day repeatedly stated they had no intentions to do so, but that was not accepted. The perceived threat was personal - 'closure would affect me personally'- and because of this generated such an extreme reaction. The new hospital built in 2005/6 may be viewed either as a symbol of the Government's sincerity or resulting from the community's symbolism.

52 Nouwen writes of community in a prayer context: 'Just because prayer is so personal and arises from the centre of our life, it is to be shared with others. Just because prayer is the most precious expression of being buman, it needs the constant support and protection of the community to grow and flower' (:139).
} 
Maslow $(1954 ; 1968)$ postulated there is an order of needs that each person seeks to satisfy. In brief these are physiological, safety (and security), belonging (love), esteem and self-actualisation (personal growth). William James (1961) preferred to summarise these as material, social and spiritual. At the highest level of this hierarchy of needs is what has been variously called self-actualisation (Maslow and Mathes, 1981), spiritual (James) and selffulfilment (Gewirth, 1998). Many other authors have pursued these concepts and once again, as with capitalism, globalisation, and community, the literature is mountainous.

A person's sense of self is closely linked with the ideal of self-fulfilment. Gewirth (1998:3) believes 'self-fulfilment consists in carrying to fruition one's deepest desires or one's worthiest capacities.' In that definition and the extension which follows, he is very similar to Maslow's (1943:91) self-actualisation: 'to be the most that one is capable of being.' The papal encyclical Sollicitudo Rei Socialis (John Paul II, 1987:33) extends that in a spiritual context: '....true development must be based on love of God and neighbour, and must help to promote the relationship between individuals and society. This is the 'civilisation of love' of which Paul VI often spoke.'

That self-fulfilment, predicated upon one's sense of self, is a fundamental and inevitable pursuit for all, would be contested by some sectors of society today. Gewirth (:4) holds its diminished status from the ideal it has been in history (he quotes Plato and Aristotle who wrote that 'the ultimate goal of the polis was not only to provide the means whereby persons could fulfil themselves but also to exemplify such fulfilment in its central institutions') is due to its elitists nature. Modern philosophers, he believes, require more emphasis be given to interpersonal relations whereby one owes duties to other persons'. This argument is contestable either way. Many organisations and individuals strive for excellence. Many companies' vision statements attest accordingly. Many people and organisations drift along. 
One of the difficulties a researcher faces in addressing these issues is the allegation, often advanced, that views thereon are personally laden and 'hallowed' ground. Because strong views thereon are frequently held, any researcher must advance so much more carefully around what some may view as evidence, others as self-evident and still others as opinions. The writer's background can achieve an importance and credibility sometimes not necessary or justified.

While these and related issues on the importance of values to a better society are fraught with difficulties of objective presentation, this author would contend that it is an even greater error to ignore background experience and values; the simple yet powerful truth that experience teaches you that some things are right and some wrong, that some things work and some do not; and that time and circumstance are influencing factors. Thus, while accepting the cautionary premise, the writer seeks to advance on the plea that 30 years of experiencing community enterprises in the best and worst of times provides a basis for discernment. Objectivity is not necessarily sought, balance is.

Thus, it is contended that Maslow's and Gewirth's pursuit of excellence concept, however it is described and defined, is alive and well in all areas of society. Community enterprises succeed or fail, as do other organisations, in proportion to its presence. There are many individuals who seek to fulfil their ambitions, that is, to attain their sense of self, through community enterprises. They pursue their goals no less vigorously than do others (frequently more so) who work in other structures like private enterprise. Dr. Ray Lyman Wilbur's ${ }^{53}$ wise words ring true for all people: 'Happiness is the true goal of man, but it comes from striving, not through drifting. To halt, to be satisfied, is in part to die. Life is an adventure and can be glorious, but not for the parasite.'

\footnotetext{
53 1875-1949. Longtime President of Stanford University. The source of the quote was a speech by J.Willard Marriott but the date is unknown. It is likely to be a speech published by Vital Speeches approximately 20 years ago.
} 
To understand community enterprises necessarily starts with recognising that each individual has a personal sense of motivation to succeed. The choices they make will be influenced by many factors, for example, their experiences, family, environment, geography, and the opportunities available. There is no gene that predisposes a person towards community employment, no more so than a person is genetically predisposed to be a farmer, a lawyer, or both. Rather, it is that vaguest of description, 'the surrounding circumstances', that more influences choices. Certainly, some people are more inclined to community association than others. Some people care more deeply to support and help others. Some are more inclined to pursue more selfish endeavours, for example their own wealth, but as Adam Smith noted, those pursuits also benefit others. But Smith's 'invisible hand' does not necessarily build a community.

That community component is now addressed.

\subsubsection{A LOVE OF COMMUNITY}

Something curious is happening to the near-religious faith that private property and markets are the only serious tools for improving people's lives. Slowly and unpredictably, like irrepressible plant life pushing its way through crumbling pavement, new models of community-based management are sprouting forth while old models are rediscovered.

The mainstream media has not caught on to this burgeoning movement, so its features remain somewhat obscure to the general public.

David Bollier (2002)

Bollier, activist, author, policy strategist and senior fellow at USC Annenberg, may or may not be right in his assertion but few would doubt that the 'notion of community has exercised an appeal as a social ideal... since the times of our Greek forefathers' (Peters and Marshall, 1988:657).

The love of, and need for, community discussed in section 2.1.3, in part explains why community enterprises were amongst the earliest of institutions 
in New Zealand; and why they have survived and remained popular to this day. Their popularity would not be without contention. The controversy surrounding the performance of five Licensing Trusts in Wellington was reflected in strong newspaper editorials ${ }^{54}$ at the time, and similarly strong editorials on the West Auckland polls ${ }^{55}$. The vitriol of the reaction may be seen as 'love spurned' but the authors of those articles would undoubtedly contest that view.

The love of community should not be uncritical. As Edelman (2000) notes, community initiatives often fail because of poor planning and unreasonable expectations. Lamm (2001) warns that good communities require 'dedication, sacrifice, and hard work.' 'Too often, Berger (1998) maintains, the dark side of community is ignored. The ties that bind can also be the justification for exclusion as in the case of immigrant groups (Portes and Landolt, 1996:3). ${ }^{56}$ Oppression and violence can also be pursued in the name of community (Strike, 1993:19) to ensure conformity to dictated or prescribed norms.

Thus, community initiatives and structures are not panaceas, even if they are essential to recognise our interdependence (John Paul II, 1987:38). But it is contended that they frequently generate an instinctive warmth. Because community is so personal, the origins of that warmth are not easy to precisely identify let alone define. But a sense of belonging, of inclusion ${ }^{57}$, the notion of the common $\operatorname{good}^{58}$, and the concept of community well-being all contribute to that warmth. An example of a community enterprise pursuing the concept of well-being is the Masterton Licensing Trust:

A UNIQUE MANDATE

\footnotetext{
${ }^{54}$ For example, The Evening Post features of 27.3.1999 and 12.3.1997, and editorials of 23.1.1998 and 22.8.1995.

55 See chapter 6.

${ }^{56}$ For a more extended comment, see note 35.

${ }^{57}$ See note 25 .

58 See note 36 .
} 


\section{THE CASE OF THE MASTERTON LICENSING TRUST ${ }^{59}$}

When the Masterton Licensing Trust was legislated into existence in 1947 it was given a unique mandate: that it should pursue its business responsibilities in the interests of the public well-being ${ }^{60}$. What that meant was not defined in the Act but in its first annual report to its community the elected Trustees 'determined to effect the greatest improvements possible' and 'to produce results which may be of historical importance'. Thus, their concentration in the early years was the provision of excellent hotels, bars, restaurants and bottle stores.

While not directly incorporated into the legislation, earlier parliamentary debates recorded in Hansard gave good indicators to Trustees what this 'experiment ${ }^{51}$ should seek to deliver. Thus:

$\therefore$ although the board should primarily be a commercial body, we should like to see the element of social welfare developed to the fullest extent in its composition' and 'to meet but not to stimulate the legitimate demand for intoxicating liquor' (1944:719).

Trustees recorded, over the years since, through press releases and annual reports, their belief bow they may best influence standards of drinking and social behaviour in their community. Examples of the excellent facilities approach were the 'Horseshoe' opening in 1951 and still operating, and the 'Solway Park Hotel' constructed in 1971-72.

In the latter half of the Trust's existence, significant effort and concentration has been given to the Trust's community donations programme. Part of the original mandate given to the Trust was that profits surplus to business needs may ${ }^{62}$ be distributed back to the community.

\footnotetext{
${ }^{59}$ For the record, the author participated in events from 1973-2002.

${ }^{60}$ The short title to the Act was: 'An Act to constitute the Masterton Licensing Trust District, and to constitute the Masterton Licensing Trust for the purpose of providing for the establishment of hotels and the sale of intoxicating liquor in the interests of the public well-being, and to provide for matters incidental thereto.'

${ }^{61}$ This was the description given to the first Licensing Trust legislation, the Invercargill Licensing Trust Act 1944, by the Prime Minister, Mr Fraser.

62 The original legislative enabling provision to distribute profits is maintained in section 189 of the Sale of Liquor Act 1989.
} 
The Trust defines its community donations policy today as supporting those organisations within their defined communities that 'offer services for the benefit or enjoyment of the community, and contribute to community well-being and/or development; organisations that provide services to those who may be denied a quality of life enjoyed by the majority; the development and well-being of the young and aged; cultural activities; and welfare and social services including the prevention and/or rehabilitation of addiction'.

In 2004 the Trust donated $\$ 3,454,729(2003 \$ 2,751,402)$ to its community from profits of $\$ 7,204,213(2003: \$ 3,784,524)$.

A sense of belonging is linked to many factors, which will vary in importance over time. One such factor is the complex agenda of self-fulfilment previously considered. Other factors are social networks, a 'shoulder to cry on', a helping hand, expectations of reciprocity, bonds of trust in others, confidence in public institutions, and norms of honesty. Putnam (2000:274-5) charts the importance of these factors from survey answers to the question: 'In what ways do you get a real sense of belonging?' It would be no surprise to most that family (77\%), friends (75\%), co-workers (50\%), neighbours (40\%) and church $(33 \%)$ head the list.

Schellenberg (2004) provides recognition of the linkages of these factors when he records that 'a strong sense of belonging is an outcome of strong social networks, which in turn broadens feelings of solidarity. Higher levels of happiness and life satisfaction' are thus more likely to eventuate. Putnam is even more definitive and assertive. People who have a strong sense of belonging trust more, give more and participate more in society (:136). Small towns have less crime because the sense of belonging is stronger (:138). Social isolation can increase suicide and depression (:264). Our health is better when our sense of belonging is strong (:326-8).

To be included and to be part of something meaningful has a logical sense for almost all people. To know our place, even though it will never be a perfect satisfaction, is infinitely better than to be adrift. Alienation brings a feeling of 
hopelessness and despair. Despair frequently turns to anger and a tendency to hit back at society that 'created' or 'allowed' that circumstances to happen. The suggestion by Larner (2004) that local solutions seem to be more in vogue pursues this logic.

'Belonging', in the context of being part of something meaningful, thus has a special significance for community enterprises and provides part of its philosophical base. It is not community enterprises' 'mere' presence or availability that is important, though that is (at least potentially) a beneficial factor, but, more importantly, the contribution they potentially make to a better way of life. Community enterprises, with their accent on the well-being of their community, provide an appeal with this sense of the organisation being 'theirs', that is, the community's.

Bollier's opening words are reinforced by Shore (2001:239): 'Young people who used to go into politics to change the world are going somewhere else to do it. Where they're going doesn't have a name yet; instead it has many names. ... Empty the Shelters... Citizen Schools...Community Impact...Sportsbridge...Jumpstart..' Shore has little doubt that what these social entrepreneurs are creating is 'profound change' that is 'not only finding more effective ways to address social problems (but) redefining democratic participation...'(:241).

COMMUNITY WELL-BEING IN ACTION: POLITICAL COMPROMISE THE CASE OF THE WEST AUCKL AND LICENSING TRUSTS

It was the evening of Tuesday 25 May 2004. The joint meeting ${ }^{63}$ of the trustees of the Portage and Waitakere Licensing Trusts had just started at the Lincoln Green Motor Hotel. There was a degree of tension in the air, and yet restraint. To this point personal

${ }^{63}$ The author was invited to the meeting. The perceptions and views recorded are his own but based upon a long history of working in licensing trusts and thus as a colleague, interviews with three of the participants during the course of compiling material for the West Auckland case study in chapter 6, a knowledge of the issues and the agenda that evening, and extensive experience of the practices, pressures and protocols of such meetings. 
comment about fellow trustees, while occasionally barbed, had been more circumspect and jocular. The Trusts did not meet together formally that often with the previous meeting six months prior.

While the infrequency of contact was probably a factor in the tension, of more significance was the history of relationship and personalities. The Trusts had long been neighbouring competitors. Both community enterprises had been established in the early 1970s and for a good part of their existence, if not the greater part, both management and boards had found themselves in conflict, sometimes generated by differing competitive practices, sometimes by jealousies of perceived status and sometimes by personalities and personal agendas.

As often happens ${ }^{64}$ pressures of survival had thrown them together in the 1990s. Both Trusts had gone through some rocky times of poor performance and indifferent decisionmaking and both were threatened by increased private enterprise competition. New management and wise heads were importantly also a factor in the Trusts' closer working relationship.

The need to work together might exist but that did not mean that animosity and distrust would disappear overnight. How each Trust perceived the needs of their community, sometimes fuelled by trustees' 'pet' projects, accentuated the difficulty of working together. Strong opinions, carried by strongly opinionated people of status within the West Auckland community (two trustees were Waitakere City Councillors and a further four were community board members) made for a volatile mix.

At stake on the agenda were an extensive range of community projects seeking support from the Trusts' donations/community support programmes. Quite sizable sums of money were involved. In the 2003 financial year the Trusts' total gifting back to their communities had topped $\$ 11$ million, and even with that amount available, many projects had to be turned down. Some hard decisions were therefore going to be necessary, again potentially adding to a contentious meeting.

${ }^{64}$ A number of licensing trusts in the 1990s grouped together to ensure their survival and the majority of
these still exist today: for example, Ashburton's linkages with Geraldine and Cheviot; Masterton's with 
What followed was continuing restraint and a disciplined approach to attempt to arrive at what was best in the interests of their communities. Debate was frank and at times vigorous. Trade offs were made. Experience and wisdom were listened to. Few would have said that the final decisions reflected all their best wishes. But it was the collective will.

The tension was almost always present but progress was made.

What contributed to this outcome may vary in importance for each person present. A busy agenda well supported by papers and President's briefings helped. So also would have the structure and process of meeting procedure, that is, there is a way to behave and buman tendency is to observe. Deference to each Trust's President particularly as to pre-agreed positions (conflicts within Trusts are best aired 'at home') would bave influenced the behaviour of some. Some Trustees and the General Manager are, by their ability and status, more influential; and finally, there would have been a desire to achieve a satisfactory outcome in the context of the Trusts' status in West Auckland.

\subsubsection{THE PURSUIT OF SOLIDARITY}

In the earlier discussion on solidarity ${ }^{65}$ the nature and attraction of the concept was canvassed. In furtherance of the belief that 'a new spirit is needed' (Baum, 1989:87), it is proposed to extend those discussions to example the successful implementation of the principle of solidarity.

Gewirth, the Edward Carson Waller Distinguished Service Professor of Philosophy at the University of Chicago, extends his argument that each has correlative duties to all others into a "principle of social solidarity. This solidarity requires institutions whereby bitherto deprived groups can be brought nearer to equality' (1996:6). There must, he states, always be a mutuality between each person's rights to freedom and well-being, and their responsibilities towards what Gewirth calls the burden of duties towards others.

Flaxmere and Rimutuka. There are parallels also in the energy industry's restructuring that occurred in the mid to late 1990s although a more likely form here was sale or merger.

${ }^{65}$ See section 2.1.4. 
It is relatively easy to moralise and to promulgate ideals for a better world. That is not to say that the establishment of principles and virtues should not be pursued and praised. For example, the papal encyclical Sollicitudo Rei Socialis has had a major influence on world policy. But principles and virtue must be practiced. As Thomas Massaro (2000) noted of Bilgrien's (1999) work designed to explain why solidarity is the key necessity for today's world, 'we still await a cogent statement of that important argument. When it does appear, the case will surely be built from a base of solid research into global socioeconomic realities, not from the type of theological reasoning that usually dominates papal encyclicals and addresses.' Massaro's cynicism reflects the everyday difficulties of implementing the ideals.

Where, then, is there evidence that the practical pursuit of solidarity has improved communities and society at large? By reviewing this, we should be better placed to judge the attributes of community enterprises.

The Tunisian Solidarity Fund vignette in section 2.1.4 is a starting point. So also should be the United Nations World Solidarity Fund. Gro Harlem Brundtland (1994), then Prime Minister of Norway, offered the Scandinavian system of social democracy with its emphasis on the group as a practical implementation of solidarity: 'My thesis is that equality can be made a productive force, rather than an obstacle to prosperity. A feeling of justice creates a climate of trust and cooperation whereas large disparities in wealth and opportunity contribute to violence and fear.' She asserts true prosperity must be shared, based on the concept of global solidarity.

Many practical examples come from the European Commission. The then President in 2003, Romano Prodi, emphasised the importance of the Commission's policy of solidarity 'to underscore Europe's responsibility towards the rest of the world.' Their web-site lists many projects under the heading of 'Solidarity is the heart of Europe' from supporting Burmese refugees in Thailand, 
Timor street children, and displaced people in Burundi and Angola, to supplying wood in Montenegro and clean water in Tajikistan.

One of the notable exponents of solidarity is the Mondragon Corporation Co-operative, now one of the largest businesses in Spain. Much has been written on Mondragon ${ }^{66}$ and the often in-depth analysis offers insight into the ways in which solidarity concepts have been implemented into policy and daily practice. Gewirth (1996:301-8) raises a number of operational and procedural issues concerning Mondragon which have particular significance to community enterprises.

Gewirth addresses the question whether Mondragon's success is entirely, partly or not at all dependent on a unique (and therefore unlikely to be replicated) set of circumstances. He lists these circumstances as the genius of its founder and the unity generated by the Basque culture of the region which manifests itself in a 'strong ethnic pride, egalitarian values and democratic government.' He concludes that while these factors have undoubtedly contributed to its success, they are not exclusive to Mondragon, and can be, and are, replicated elsewhere.

The conflicts that arise from the competing demands of self-interest, competitive pressures and the co-operativeness and solidarity upheld by socialism, including the structure of rights which has been attributed to economic democracy' have been effectively managed by the mechanisms that Mondragon have adopted to ensure compliance of its solidarity principles, states Gewirth. For example, the Standing Committee and the General Council's responsibilities are well defined and include an educational mission to teach the necessity for respect of human rights. In effect, solidarity's principles are institutionalised. This practice contains an important lesson for community enterprises. Unless they regularly remind themselves through their processes of their prime purpose (that is, the well-being of their defined community), other priorities (for

${ }^{66}$ For example, Whyte and Whyte (1988). 
example, personal aspirations and financial results) will inexorably roll in and over the social goals.

Solidarity is not a dream or pious wish made occasionally real by an idealistic person or group. It is a strident necessity made very difficult by competing, often selfish, aspirations. There will always be people who struggle to cope and it is rarely clearcut whether the cause is their own lack of endeavour or a genuine disadvantage. To accept Gerwirth's 'community of rights' that I have correlative duties towards all others is far from easy. It is relatively easy to do so for immediate family (although here too the trials from time to time can be extreme) but it becomes increasingly difficult as the bonds become more remote. What seems to be required towards our neighbour can appear to be of biblical proportions, 'love your neighbour', and in an arguably more materialistic world, that may often be in short supply. But Shore (2001:239) and Bollier (2002) encourage us otherwise, and Mondragon and other examples give positive hope that a movement towards a greater acceptance of the principle of solidarity is occurring. Community enterprises are one more practical step along that journey. They start with an ideal but deal with the discordant realities of life: genuine suffering and disadvantage. As Gewirth and others would state: someone has to care enough to provide remedies, otherwise we all suffer.

For community enterprises one of the practical and constant realities is the need to exercise enterprise to survive. It is to these enterprise attributes that the thesis now turns.

\subsubsection{ENTERPRISE}

The fourth component that comprises the community enterprise model is enterprise. Its layers and shades of meaning are explored in what follows.

At one level enterprise provides a categorisation. It can be a business unit such as a state owned enterprise, private enterprise or a community 
enterprise. At another, it may represent the degree of initiative and resourcefulness brought to a task or venture. It is an appropriate word for the last component of the schematic because it suggests effort and commitment but significantly helps to define by contrast to private ownership; for enterprise also implies an element that is inherently personal. This section therefore will explore these meanings and their impacts under the following headings: private enterprise attributes and the adjunct issue of the efficiency of public bodies which is the heart of the privatisation debate; and personal skills: community benefits which discusses the desire to use one's personal knowledge for the benefit of the community.

\subsubsection{PRIVATE ENTERPRISE ATTRIBUTES}

A discussion of private enterprise is essential to place into perspective the nature of community enterprises. By definition, community enterprises are frequently dependent on profits to survive and to generate funds so that their primary goals may be pursued. The profit motive, the desire to achieve a financial gain from buying, producing, or operating, and selling, is at its roots an individual pursuit under private enterprise. This holds good even at the multi-national firm level where ownership may be split into millions of individual share lots. ${ }^{67}$ As Seldon (1980) states: Private enterprise is the source of economic growth and rising living standards because it works with the grain of human nature expressed in the market.'

Community enterprises, most often, have no formal structures of ownership as private enterprise would use that term. The TSB Community Trust, for example, has no shareholders. Instead, that Trust has as its beneficial owner the Taranaki community at large. On the face of it, therefore, ownership is

\footnotetext{
${ }^{67}$ Some argue, for example, Gates (1998:xxvii),with a good deal of validity in particular cases, that at this level ownership (that is, shareholding) is frequently disconnected, indifferent to and remote from operational ownership (that is, managers and directors). An example would be where a person invests in a large company perhaps through a unit trust or directly through a share script, and their desire is solely a return on their investment either through dividends or a rising share price. Their motive may be, thus, solely limited to a profit and there may be no sense of ownership beyond that. Nonetheless, there is a right to property which is at the core of private ownership.
} 
even more remote and seemingly nebulous. ${ }^{68}$ How then does the concept of (private) ownership connect with community enterprises or are the latter a form of creeping socialism ${ }^{69}$ and thus likely to struggle to survive, and then over time be no longer fashionable, particularly as the original ideals fade or management succession occurs.

Private enterprise has these features:

- The freedom to engage in creative enterprise, at the level of contribution and effort that the individual chooses without regulation and restriction other than just laws.

- The bounded right to private property, not without responsibilities, but nonetheless a right to call property their own, and use and dispose as they wish.

- Incentives (for example, wages, rents, profits) that encourage individuals to contribute their resources at the level they wish, and by so doing, increase the 'common pool' (Seldon, 1980) of standards of living.

At the heart of private enterprise is the desire to do better and seek more. As Epstein (1995:75) records: This characteristic of wanting more is universal. It applies to greedy and rapacious firms and selfinterested individuals. Indeed, wanting more is not a characteristic for which we should want to condemn people. The desire for more is one of the few features that is indispensable for buman progress and advancements.'

\footnotetext{
${ }^{68}$ McKinlay (1999) comments on these issues for the community trusts in New Zealand.

${ }^{69}$ This is a criticism that has been levelled at the 'Third Way' movement (that is, after market fundamentalism and socialism). Notably, social enterprises in the United Kingdom have been promoted by that county's Labour Government, the same government that promoted the Third Way movement. For a brief coverage of its origins see Giddens (2001).
} 
The freedom to be creative, to choose the level of effort and engagement of resources, and to seek to be rewarded according to that level of risk, creativity and resource utilisation, are at the core of private enterprise.

None of these attributes are restricted to private enterprise. Creativity, risk and reward are the foundations for much of human endeavour whether in business, sport or in the wider arena of life. The freedom to choose, and thus to 'own' the effort and its outcomes provides a fundamental understanding of why private enterprise works better than directed or regulated efforts. This concept of freedom is not restricted to private enterprise structures. Examples would be where an individual seeks to succeed at a sport, in the arts, or as a minister of religion. The rewards may be in recognition and self-fulfilment, and not in financial gain.

The conclusion that can comfortably be reached is that the attributes of private enterprise are applicable universally. Jensen and Meckling (1994:22) summarise this well: we 'care, not only about money, but almost everything - respect, honour, power, love, and the welfare of others.'

Another perspective to reinforce that conclusion can be gained from Peters and Waterman's research (1982:13-) into the attributes of excellent companies. $^{70}$ They listed eight. These attributes are equally applicable to community enterprises. The challenge, of course, is always constant: how to apply successfully these and other theories, for example, agency. ${ }^{71}$

But at the heart of human endeavour there is simplicity. What we own and love, we cherish and protect.

\footnotetext{
70 The eight are: a bias for action, a closeness to the customer, autonomy (freedom) and entrepreneurship (creativity), productivity through people, being hands on and values driven, sticking to the knitting (what you know you can do and do well), simplicity of form and lean of staffing (minimisation of bureaucracy), and tight-loose (that is, both centralisation where necessary and decentralisation of decision-making where it is not).

71 Agency costs are likely to arise in organisations of a reasonable size. The theory relating to agency is applicable to community enterprises as it is to private enterprise. Jensen and Meckling (1976) and Jensen (1994) provide treatments of the issues which, while important to the performance of
} 
The privatisation movement that was strong throughout the 1980s and 1990s seems to challenge the universality of a theory that suggests ownership and commitment can successfully be at a 'felt' and 'commons' level. As Arthur Seldon (1980) states: 'The private enterprise economy has shown that the more scope it creates for individual initiative, the higher living standards can be raised.' But Seldon who, along with Lord Harris at the United Kingdom's Institute of Economic Affairs, is credited with the thinking behind the Thatcher's Government's privatisation policies in the 1970s and 1980s, also wrote (1980) : 'A free economy based on private initiatives is powered by self-knowledge, not selfishness. It does not exclude compassion for the "under-privileged'. Its productivity creates more opportunity for making compassion "more" feasible and "more" generous than in state economy. A free economy creates no bindrance to disinterested effort organised for the benefit of people or causes: from the old or sick who cannot help themselves to art galleries, opera or other artistic activities that consumers will not finance in the market.'

But a case for the successful existence and operation of a 'public body' like a community enterprise should recognise the lessons of privatisation. Generally, with a number of important qualifications, private enterprise structures are more efficient at operating trading enterprises ${ }^{72}$ than governments. Why this is so predominantly revolves around the stultifying effects of bureaucracy. What is not so clear, largely because the privatisation literature concentrates on the comparative performance of state or publicly owned enterprises and private enterprise, is how community enterprises compare with equivalent private structures. Community enterprise suggests a less remote 'Ownership' than public ownership. While that line of thought is extended in section 2.3.2, to a large extent a comparison of performance between private ownership and community enterprises is a side-show for this thesis. It has importance to assure that resources engaged are not wastefully used; and that there are not better ways to achieve the mixture of social/community goals and economic

community (and other) enterprises, are not the focus of this research. Teahan (2000:29) discusses aspects of agency costs relating to publicly owned organisations.

72 For an explanation of the current status of the privatisation debate see note 46. 
goals that community enterprises pursue. But any comparison has significant elements of not being like to like. Community enterprises have a different emphasis than private enterprises. The creation of wealth is not a prime goal. The well-being of a community is.

\subsubsection{PERSONAL SKILLS: COMMUNITY BENEFITS}

Another attribute of the enterprise component is the desire to use personal skills for the benefit of the community. This desire will usually be driven by altruistic and personal (selfish) motives with the weight given to one over the other likely to vary over time and to be somewhere along a continuum between the two. For example, a Trustee elected to the Masterton Licensing Trust may see their involvement a result of a desire to contribute their skills for the benefit of the community, or an opportunity to increase their political profile as a prelude to larger political aspirations, or both. The vignette in section 2.2.1 gives further examples of the varying motives, as also do the discussions on self-actualisation and spiritual needs in that section.

These, then, are the four concepts that together provide a philosophical framework for community enterprises: a sense of self that contributes the motivational start; a love of community that is necessary to fulfil the self; a pursuit of solidarity to reflect fairness, equity and justice; and lastly a marriage to the attributes of (private) enterprise, notably entrepreneurship and innovation, risk and reward, and ownership.

There remain three issues that writers have suggested may contentiously impact on the performance of public and community-owned organisations generically; that is, these issues may be organisational flaws. These are now addressed.

\subsection{CONTENTIOUS ISSUES}

\subsubsection{THE MIXING OF GOALS}


There are some (for example, Kulkarni, 1979; Negandhi and Ganguly, 1986) who have suggested that the mixing of social and economic goals is unwise, while others (for example, NZPSA, 1989) see no difficulty. It is worth noting that in New Zealand both the State-Owned Enterprises (1986) and Energy Companies (1992) were required by their legislation to be successful businesses foremost (Teahan, 2000) with the outcome that neither pursued social goals of any consequence (Spicer et al, 1996; Kelsey, 1995). This suggests that this 'mixing of goals is unwise' admonition achieved some credibility in New Zealand and for this reason, and the reason that this premise may be an institutional flaw, deserves attention in this thesis.

Kulkarni's (1979) advice, generated from data from Indian state enterprises: 'where different policies of government have contradictory objectives, e.g., commercial efficiency, performance of developmental tasks... it may be unwise to use the same corporation as the combined instrument for all the policies', is in the particular circumstances of that government's involvement, and is now over 25 years old. Governments, of course, pursue political agendas. When those agendas include such goals as distributional equity, it may well be desirable to separate that responsibility from the demands of running a successful business enterprise. An example in New Zealand would be requiring Mighty River Power, a state-owned enterprise electricity generator, with nine hydro power stations on the Waikato river, and electricity retailer, to also be responsible for income support schemes for the elderly who may not be able to afford necessary heating costs. Conflicts of interests and priorities have a real chance of being debilitating, should that occur.

Jensen and Meckling's (1994) seminal work 'The Nature of Man' offers an alternative theme. They maintain that man is 'resourceful, evaluative and maximising'; and that '(individuals) respond creatively to the opportunities the environment presents to them, and they work to loosen constraints that prevent them from doing what they wish to do.' As noted in the previous section, people care deeply over very many things, and can maintain an intense commitment to a range of 
issues. No evidence is needed to support this statement; it is self-evident from our daily life.

That people care not only about money, but also about the welfare of others highlights why some people are drawn to community enterprises with their primary focus on social/community goals. But while 'The Nature of Man' provides some explanation for people's choices, it also reinforces the core components of private enterprise. Private enterprise is frequently interpreted to mean individuals will seek to achieve the highest level of wealth reward. Jensen and Meckling emphasise that maximisation of reward will be sought, but not necessarily solely related to economic reward. Pursuit of a range of goals is entirely consistent with the human condition. Profit may be achieved in a way similar to Shore's (2001:124-) example of Pioneer Human Services in Walla Walla, Washington that has achieved a turnover in excess of $\$ 50$ million by manufacturing and selling high quality products and services with a workforce made up entirely of ex-offenders and former substance abusers'. In so doing, it achieves social goals through the generation of profit.

The premise, that individuals routinely choose a mixture of goals, opposed as it is to Kulkarni's (1979) and Negandhi and Ganguly's (1986) admonition that the mixing of social and economic goals is unwise, is fundamental to the formation of community enterprises.

As Jensen and Meckling postulate, individuals (and enterprises) will pursue a range of goals that will vary from time to time as circumstances change. An individual may, when younger, place the greater part of their energies into business (wealth generation) pursuits. When those desires are more adequately met, greater emphasis may be given to other wants, for example civic life or recreation. Thus Kulkarni's (1979) warning has quite limited theoretical applicability to community enterprises.

There are, however, practical dangers. Kulkarni also warns (:27) 'in the long run, the economic objective will tend to gain preference over all other objectives which are socially 
important and desirable'. The focus and concentration brought to bear on a goal bears a direct relationship to its successful implementation. Economic goals are often easier to measure and the profit measurement mechanisms are well advanced. Often it is not so easy to judge how well a community well-being goal has been achieved. For example, the TSB Community Trust's 'positive opportunities' (see chapter 7) has a significant degree of subjectivity. As Porter and Kramer (1999:130) note in their comments on philanthropy: 'Until foundations accept their accountability to society and meet their obligations to create value, they exist in a world where they cannot fail. Unfortunately, they also cannot truly succeed.'

COMMUNITY SUPPORT THROUGH ENTRENEURSHIP

THE CASE OF THE TARARUA FOUND ATION ${ }^{73}$

The Tararua Foundation was formed as a charitable trust in August 1985 on the initiative of the Masterton Licensing Trust who saw "major benefit" in establishing an organisation which would pursue charitable purposes from profits generated through business opportunities. Membership of the new body came from trustees of the Masterton Licensing Trust, the chairmen of the Masterton County Council and Masterton Trust Lands Trust, and the Mayor of Masterton. That diverse membership would also allow better 'joint liaison' between those four organisations 'for the charitable benefit of the community'.

From the beginning the Foundation generated business profits from its ventures and distributed a significant portion to the communities in which they operated: Manawatu, Wairarapa and Wellington. While up to 1997 it owned and operated those businesses directly, in that year it entered into an agreement with its original initiator, the Masterton Licensing Trust, for both to sell their assets to a new charitable company, Trust House Limited, and in future to receive dividends from its shareholding (for the Tararua Foundation, 20\% of Trust House Limited) which would then be the source of its distribution to its defined communities. The Chairman reported in his 2004 annual report

\footnotetext{
${ }^{73}$ For the record, the author participated in many of these events from 1985-2002.

74 Press release dated 9 September 1986 and reported in the Wairarapa Times-Age.
} 
that for the year just past, the Trustees had approved 183 grants totalling \$618,906, the largest being \$40,000 to the Arohanui Hospice and the smallest \$461 to the Pabiatua Plunket.

Their meeting agendas and annual reports give insights as to how they mix business management with philanthropy. Financial reports are considered at each meeting which is usually quarterly with special meetings from time to time. Business plans are approved annually in March and audited annual accounts in Jub. One trustee sits as a director on the Trust House board where he is privy to more detailed financial reports monthly. The Chief Executive of that company also provides a quarterly report to the Foundation on key matters.

Grant applications are considered at every meeting. There is a detailed process of consideration including application forms and support information from the applicant. For major donations it is likely that a presentation from representatives of the applicant would be beard. Often field visits are made to view first hand the project. Three times a year grant recipients are present at functions where 'trustees meet with the many hard-working people who carry out a great variety of unpaid work on behalf of these communities. ${ }^{75}$ The Chairman, Brian Bourke, stated: Talking with people on these occasions helps us understand the many hardships faced by some very worthwbile organisations and how our grant will make a difference'.

\subsubsection{OWNERSHIP}

The second challenge to community enterprises comes in the nature of an understanding of ownership.

Community enterprises, by their nature, rarely have a private enterprise style share structure. Indeed, they almost always build equity through profit generation. Thus, the sense of ownership that comes from a monetary investment is usually not available to them and a number of writers and

\footnotetext{
75 Tararua Foundation's 2004 annual report .
} 
politicians have stumbled over this issue. How can there be a lasting commitment to community enterprises if an individual does not have a financial stake?

Inclusion, built on commitment, goes to the heart of community. The right to hope, and to expect our hopes may be fulfilled is at the core of human existence, and to happiness.

Can then, at least here in the theory, and later in the case studies the reality, community enterprises deliver a sense of inclusion and contribute towards a more inclusive society?

To be included implies involvement and involvement leads to a degree of ownership, and commitment flows there-from. It is reasonable to assume, even to recognise, that it is integral to the human condition that there will be a greater commitment to what we own. Private enterprise is predicated on this belief and so also are a host of everyday organisations: sporting clubs, arts and crafts groups, and political parties. Private enterprise commitment is often grounded in a monetary stake whether it is investment or wages. The ownership credentials for a myriad of clubs are a more tenuous link. To be part of may flow from a subscription but it may be closer, in most circumstances, to reality to state that a sense of ownership is gained therein by a range of factors, for example, participation in the activity, recognition, a sense of satisfaction ... the list may extend or shorten for the individual and the occasion. Thus, there is a need to view 'own' in a wider interpretation. There are many things we own, and that we are committed to, for which we do not have a financial stake. Beliefs and values are examples.

McKinlay (1999) struggles with this ownership issue for the community trusts in New Zealand. His confusing and not compelling solution to these 'ownerless assets' for which 'neither trust banks nor energy trusts have an effective mandate or any realistic prospect of obtaining one on a stand-alone basis' is for local government to 
have a role 'in ensuring that local accountability is real, transparent and effective' (:1634).

Once again it is arguable that ownership is viewed too narrowly, and too abstractly. Those who see community enterprises as fundamentally flawed, even unsound, through a lack of definite ownership structure (by inference, in comparison to a private enterprise structure where a share/stock system allows easy exit if there is concern over performance ${ }^{76}$ ) have a limited understanding of the nature of organisations and their dynamics, and the nature of the human condition. As Jensen and Meckling (1994:22) well argue in their 'The Nature of Man', people care about money but also about 'almost everything.' They state the challenge well for all organisations in society: '...to establish rules of the game... that tap and direct creative energy... in ways that increase the effective use of our scarce resources'.

Thus, the ownership contention for community enterprises is not to see ownership in a narrow context. That communities do not own their community trusts is refuted by the vigour of the community's interest in the two West Auckland Licensing Trusts (see chapter 6) and the considerable debate and conflict over the Hutt Mana Energy Trust ${ }^{77}$. The Eketahuna case study in chapter 5 is a remarkable example of a whole community owning the solution to their threatening demise. Thus, while the everyday evidence of support is before us, so also is rejection of community structures manifested in, at times, vehement rejection. An example of this is the strong community polarisation that occurred in West Auckland (see chapter 6). As that study notes, there were a complex agenda of reasons why that occurred.

There is another side to a debate on ownership. Both Gates (1998) and Shuman (2000) are strongly critical of the deficiencies (not the concept) of

\footnotetext{
${ }^{76}$ Both Gates' (1998) and Shuman's (2000) themes are that in capitalism the ownership benefits flow to a few with much investment remote and concerned only with the numbers (ROE).

${ }^{77}$ For example, see The Dominion Post editorial of June 26, 2003.
} 
modern day capitalism. Both books resonate with the philosophy driving the concept of community enterprises.

Gates (:xix) warns that while capitalism 'extols the necessity of private ownership... contemporary capitalism is not designed to create capitalists, but to finance capital.' $\mathrm{He}$ repeats Thomas Jefferson's warning that 'a disengaged citizenry could be democracy's undoing' and asserts that we 'need to reconnect personal conscience to market capitalism' (:xx).

Gates' answers to his eloquently placed concerns, while cautioning to proceed with care and thus to steadily broaden ownership rather than radical change, are a 'shared capitalism' that 'bas the potential to serve as a social cohesive, a societal binding agent that connects people to their communities, to their capitalist culture and to their natural surroundings' (:115) and to bring 'genuine community into your business' (:149). Drucker (1998:4-6) qualifies that a little. He acknowledges the need for community but doubts that the private sector can ever fill that need and classes business as a society rather than a community. ${ }^{78}$ Fukuyama (1995:32) makes a supporting assertion that 'those who pay attention to community may indeed become the most efficient of all.

Shuman takes the solutions further in advocating that communities should increase their self-reliance and not be so dependent on corporations and organisations headquartered outside their environs. In discussing forms of ownership that may increase a community's self-reliance 'the most promising model may well be a for-profit with a residential restriction on stock ownership' (:88).

The latter, which need not require a totality of ownership within the community, do offer a good deal of promise. A community does then have a stake as it is more conventionally understood in private enterprise structures. It can better ensure that it is an active party to any decision on its future. A sense of ownership would more easily be translated to community members,

\footnotetext{
${ }^{78}$ In this same essay, Drucker extols the necessity, and the growth, of the non-profits which he believes are 'the only ones that can satisfy ... the need for effective citizenship.'(:0)
} 
and thereby potentially offer greater inclusion. There is, of course, no substitute for good management generating trust, respect and acceptable performance. Without that no organisation can hope to succeed.

In summary, ownership of community enterprises must be viewed on a wider interpretation than a financial stake. The nature of a club is a more fitting analogy for community enterprises. A sense of ownership will frequently present challenges, but rarely should they be insurmountable.

\subsubsection{THE NEED FOR PROFIT}

Equity has the potential to be an issue of consequence for community enterprises, for rarely do they have sustained access to equity capital other than through profit generation.

So was it so with Licensing Trusts, for some of whom the lack of start-up capital was debilitating. Some were not able to begin trading despite the availability of licence approval by the Licensing Commission (Teahan, 1990:32).

THE NEED FOR PROFIT:

THE CASE OF THE FLAXMERE LICENSING TRUST ${ }^{79}$

It was mid 1984 and the Trust faced a case crisis of some magnitude. They had current assets of $\$ 38,000$ to meet immediate liabilities of $\$ 189,000 .{ }^{80}$ In addition, in November a loan repayment of $\$ 30,000$ plus interest was due. The bank overdraft was up to its limit and most creditors were overdue for payment.

The Trust was insolvent.

\footnotetext{
${ }^{79}$ For the record, the author participated in many of the events from 1984-2002.

80 Source: annual accounts of the Trust for the year ended 31 March 1985 and Flaxmere correspondence files.
} 
The community enterprise had begun, as so many do, in idealism and enthusiasm. In 1972 Flaxmere was a small dormitory suburb of Hastings, barely 100 bouses. ${ }^{81}$ A group of citizens led by journalist, and later editor of the Hawke's Bay Herald-Tribune, decided a community-owned Trust should construct and own a proposed tavern and restaurant.

Significant difficulties had to be overcome ${ }^{82}$ before a legal trust was established in $1975^{83}$ and it was four more dedicated years before the Tavern was opened in 1979. That it opened at all was a notable achievement. Finance in particular was a major burdle to overcome. Not only had the full construction cost to be borrowed, establishment costs also had to be financed out of more debt. 'On opening day, the Trust was an incredible 110 per cent in debt.' James Morgan, Recollections on the beginning of the Trust.)

The legacy of the debt and operational difficulties grew in complexity to arrive at the crisis in 1984.

Solutions to all of Flaxmere's problems took some years to achieve but the most crucial one was to obtain the management support and backing of the Masterton Trust, their Licensing Trust neighbour 200kms to the south. That Trust, then with 37 years of experience, provided the management skills and support to restructure debt, give confidence to creditors and bankers, and most importantly, provide operational skills to ensure a profit.

Today ${ }^{84}$ the Flaxmere Trust has

- Income of $\$ 2.258$ million

- Assets of $\$ 1.994$ million

- No debt

- Equity of \$1.662million

81 Source: 25 year anniversary booklet: the recollections of James Morgan.

82 The 25 year anniversary booklet records a number of these, as do the correspondence files. The personal recollections of James Morgan, John Bradshaw (foundation Trustee) and Ken Kibblewhite (Trustee since 1977 and President since 1990) also refer.

83 The Flaxmere Licensing Trust Constitution Notice 1975 dated 11 April 1975.

84 All figures quoted are from the Trust's annual accounts for the year ended 31 March 2004. 
- Profit last year of $\$ 431,810$ (wbich includes the gaming profit generated from their business premise) and

- In the last five years distributed $\$ 1,245,400$ to its community in support of a wide range of activities and organisations. Major community projects have been the installation of fire alarms in every Flaxmere home and the computers in homes scheme (\$350,000 gifted) in partnership with the Flaxmere College. The President, Ken Kibblewhite emphasised that the Trust saw its education partnerships with the local schools and the community as being the cornerstone of its desire to raise living standards within the Flaxmere community.

Community enterprises are not without equity sources other than profit as Eketahuna exhibited when the community willingly and generously advanced their own money in the form of interest free debentures, some of which became grants when residents did not seek repayment (see chapter 5). The most common form of start up capital for non-statutory enterprises ${ }^{85}$ would be grants, sometimes from Government agencies and often from philanthropic trusts and foundations.

The lack of structured equity creates three issues. The first of these is that community enterprises tend to be under-capitalised and because of that more pressure tends to be thrown on profit performance, the second of the issues. The British Government recognised these pressures in their blueprint for social enterprises ${ }^{86}$ and suggested a number of priorities, one of which included commissioning a special report by the Bank of England (May, 2003).

The third issue is more subtle but arguably is of the greatest significance. The lack of a 'ready' source of equity capital is frequently perceived to be a weakness and deterrent for those considering structures like community enterprises. The comparison is made to the easily understood private

\footnotetext{
${ }^{85}$ For a description of the various categories of community enterprises see chapter 3.

${ }^{86}$ See Social Enterprise... a strategy for success, Department of Trade and Industry, July 2002:62-71.
} 
enterprise structures where the owner(s) are a source of support. The perception is that community enterprises are more fragile and a greater risk, particularly when ownership is understood in more bounded terms ${ }^{87}$. Lenders will therefore be more cautious.

The challenge is not to be so constrained to traditional sources of equity capital and to pursue other models, such as those suggested by Gates (1998), Shore (2001) and Shuman(2000).

\section{A NEED TO BETTER BALANCE THE LEDGER?}

It is arguable that because individual rights have been so prioritised over the past few decades that the fragile balance that is necessary for the unattainable yet essential goal of an ideal society has been tilted too far towards selfishness, thus giving rise to conflict. Again, it is arguable that there is a greater need to move beyond self to help. Only through being part of a meaningful effort (which in itself will be subjectively interpreted) that helps others do we help ourselves. What makes a better society is a better me. What makes a better me is moving out from my needs to others'. Only by helping others do I finally give meaning to me. And that, primarily, is why we would benefit from community enterprises: to restore the balance lost in the last decades to the march of market forces; and to give greater opportunity for self-fulfilment. Cohen (1985:107) examples this well when he suggests that community association may provide 'a model for the political formulation of (their) interests and aspirations'. His quotation opening section 2.2.1 is worthy of repetition: '... people assert community, whether in the form of ethnicity or locality, when they recognize in it the most adequate medium for the expression of their whole selves.'

\section{SUMMARY: PULLING THE STRANDS TOGETHER}

\footnotetext{
${ }^{87}$ The comparison here is between the traditional form of ownership - 'I own this' - and a club style -'T am committed to this; therefore I own it'.
} 
Both Giddens and Putnam advance the case for new institutions appropriate to the global age. Gewirth requires acceptance of mutual responsibility towards others. Stiglitz and Fukuyama highlight the need for balance and complementary (to the predominant private enterprise) models. Therein lies the case and the challenge for community enterprises.

But at a deeper level, the components of community enterprises (the individual drive for self-fulfilment, the need for and benefits of community association, the support of others, and the attributes of enterprise) are well 'ordered to the fullness of human life, the preservation of human dignity, and the safeguarding of human rights (Weigel, 2000:5), while also offering the opportunity for 'deeper aspirations' (Sollicitudo Rei Socialis, 1987:27) to be satisfied.

Community enterprises with their primary emphasis on supporting and enhancing the well-being of a community through profits generated from their trading activities are not a new phenomenon. In New Zealand the first examples were formed within a few years of the Treaty of Waitangi. They have their parallels in the 'not-for-profit' models common throughout the world. But that title is a misnomer. The 'enterprise' of community enterprise reflects a significant challenge: only through sustained profit generation will they be able to survive and able to achieve their primary goals. ${ }^{88}$

The literature reviewed in this chapter fairly allows some fundamental conclusions to be reached:

- The characteristic strengths of the private enterprise model harmonise with community enterprises, or in another way, the enterprise attributes of entrepreneurship, innovation, risk and reward, ownership and commitment are not exclusive to private enterprises;

\footnotetext{
${ }^{88}$ Some may be able to supplement income generation with grants from philanthropic bodies and (local) government. But in most circumstances this is a fickle existence and usually not sustainable.
} 
- Community enterprises' business pursuits allow profits generated to be distributed in community support thus lessening the need for increased government or state involvement; the principle of subsidiarity is therefore supported;

- The pursuit of mixed goals (economic and social/community) is a common life experience and, while carrying some provisos, should not provide barriers to successful achievement;

- Community association, that is, the strengthening of community initiatives, offers a great deal to the ideal society through inclusion for a greater number of citizens, a lessening of alienation and conflict, and opportunities for enhanced self-fulfilment through the pursuit of community well-being.

- Mutuality, represented by the principle of solidarity, is increasingly recognised and pursued as a cornerstone of the ideal society.

The four component schematic summarises and simplifies the characteristics of community enterprises. Each of the four has underlying shades of meaning. For the case studies (chapters 5-8) and cross case analysis (chapter 9) to as effective and searching as possible, these underlying shades need to be recognized so that their different hues are not lost. Thus, they are presented in Table 2.1 and form the base structure of the case studies and the analysis: 
TABLE 2.1

\section{CONSTITUENT PARTS OF COMMUNITY ENTERPRISES}

\begin{tabular}{|c|c|c|c|}
\hline $\begin{array}{l}\text { SENSE OF } \\
\text { SELF }\end{array}$ & COMMUNITY & SOLIDARITY & ENTERPRISE \\
\hline $\begin{array}{l}\text { Shared culture } \\
\text { Bounded }\end{array}$ & $\begin{array}{l}\text { Belonging and } \\
\text { inclusion }\end{array}$ & $\begin{array}{l}\text { Reciprocity and } \\
\text { mutuality }\end{array}$ & $\begin{array}{l}\text { Use of personal } \\
\text { skills }\end{array}$ \\
\hline locality & Common good & $\begin{array}{l}\text { Support of the } \\
\text { disadvantaged }\end{array}$ & $\begin{array}{l}\text { Creativity and } \\
\text { innovation }\end{array}$ \\
\hline $\begin{array}{l}\text { Referent of } \\
\text { identity }\end{array}$ & $\begin{array}{l}\text { Community well- } \\
\text { being }\end{array}$ & $\begin{array}{l}\text { Support of the } \\
\text { community }\end{array}$ & Risk and reward \\
\hline $\begin{array}{l}\text { Boundaries } \\
\text { threatened }\end{array}$ & Social Networks & Sharing of & Incentives \\
\hline Self-fulfilment & $\begin{array}{l}\text { Bonds of trust } \\
\text { Confidence in } \\
\text { public institutions }\end{array}$ & $\begin{array}{l}\text { prosperity } \\
\text { Caring }\end{array}$ & $\begin{array}{l}\text { Governance and } \\
\text { agency }\end{array}$ \\
\hline
\end{tabular}

The vignettes provided throughout this chapter to illustrate and emphasise particular themes suggest that there are a lively and successful range of community enterprises in New Zealand that have stood the test of time. Overseas literature highlights renewed interest in this model.

What follows in the next chapter is a review of community enterprises in New Zealand and elsewhere. 
Chapter 3

\section{COMMUNITY ENTERPRISES WORLDWIDE AND IN NEW ZEALAND: THEIR STRUCTURE, FORM AND PRESENCE}

Where the previous chapter concentrated on building and defining a framework that was theoretically sound and philosophically robust, chapter 3 takes a more practical theme. Emphasis is given to examples of community enterprises now operating, thus putting into practice the ideals and theories that were the essence of chapter 2 .

The chapter will be split into four sections. The first presents an overview of The Civil and Solidarity-Based Economy of which community enterprises are a part. That discussion is illustrated with worldwide practice and examples. From that broad view the picture is narrowed down into the types of organisations mushrooming throughout the world, both developed world and developing, under the title of Structure and Form ${ }^{89}$. The United Kingdom policy document on social enterprises is given separate treatment because of its importance, particularly to New Zealand. And finally New Zealand examples complete the chapter.

\subsection{THE CIVIL AND SOLIDARITY-BASED ECONOMY}

\footnotetext{
${ }^{89}$ Form and structure are often referred to as synonyms and they are treated in this chapter in a coexistent way; that is, while descriptions of form and structure can often blur into one another, for the purpose of this presentation, sharp distinction is not necessary. The distinction intended is that Structure is represented in the various generic types of organisations in the third sector. Form represents their essential nature and visible shape. Examples will be given of both, thus representing their presence.
} 
Third sector organisations come in many forms and represent many interests, so much so that it seems that the only limits are those of the human imagination. Shore (2001:239-241) was close to stating this when he described the phenomenal growth of community nonprofit organisations and the exodus from politics to social entrepreneurship of those who wish 'to change the world'. The 'failed state', contends Fisher (2003:19) is one significant reason for this occurrence: that is, an increasing number of people do not see the state as a viable answer to the problems that concern them. Bollier's quote recorded at the start of section 2.2.2 attests to this vitality and its uncertain form. Other authors [for example, Salamon and Anheier (1997), Laville (2003), OECD (1999)] evidence this same trend: there is great growth and vitality in this sector of society. It has a variety of names: the civil society, the civil and solidarity-based economy, the nonprofit sector, the third system, the third sector, the social/solidarity based economy; this list is increasing as more researchers attempt to come to grips with what is happening and inevitably provide their own definitions and titles.

What then is this sector? What role does it play? How large is it? And what part do community enterprises play?

Salamon and Anheier's (1997) major study, often cited, of the key institutions of the private-voluntary and nonprofit sector of the USA, UK, France, Germany, Italy, Sweden, Hungary, Japan, Brazil, Egypt, Ghana, Thailand and India give some visibility to this civil society but as they acknowledge, it is a far from complete picture. Its very diversity is one factor that creates difficulties in definition and measurement, but so also has the emphasis on the market model and the state or public model led to an opaqueness of recognition. A further reason why what Salamon and Anheier call perhaps the 'greatest social innovation of the twentieth century' (:1) has not being recognised as such, may be political agendas. They suggest that neither the political Left nor Right seek to give emphasis to civil society's growth and vitality; the Left because 'too positive a view of the capabilities of nonprofit institutions could undermine 
support for the expansion of modern governmental protections against the risks of poverty and distress'; and the Right because of their assertion that too much government 'displaces nomprofit groups' (:2). That view may have an element of truth but it is hard to give it too much credibility. As Bollier infers, it is probably more likely that its very newness creates the lack of clarity. Salamon in his latter work (2003:3) recognises that statistical conventions have tended to hide the growth of the third sector.

Nonetheless, Salamon and Anheier are able to provide some definition. 'Membership associations, local community groups, clubs, health care providers, educational institutions, social service agencies, advocacy groups, foundations, self-help groups, and many more' make up on average around $6 \%$ of total employment, and better than double that of the job growth of the 1980s. For eight of the countries mentioned above for which data was available, civil sector expenditures of $\$ 614$ billion in 1990/2 equated to almost 5\% of combined gross domestic product. The Economist in 1998 (November 14:68) provides more recent comparisons. Between 1990 and 1995 'non-profit' jobs grew at almost 4 times the rate $(23 \%$ to $6 \%)$ for the whole economies of the 22 developed and developing countries measured. There is variability across countries as different patterns of market and government policies impact.

In 2003, Salamon, through the Johns Hopkins University School of Advanced International Studies, updated the earlier study to extend to 35 countries. Therein, the 'nonprofit sector engages nearly 40 million people and has annual expenditures of \$1.3trillion, larger than the gross domestic product of all but the six largest countries.'

Salamon, whose ongoing studies are rippling out to additional countries (including New Zealand), provides a definition of the 'civil society organizations' that populate the 'civil society sector'. They are 'essentially private, i.e., outside the institutional structures of government, not primarily commercial and do not exist primarily 
to distribute profits to their directors or "owners"; they are 'self-governing' and 'people are free to join or support voluntarily.' (2003:Preface; also 7-9)

Income generation patterns are interesting. The greatest contributor to these organisations' revenues is from fees and sales (49\%), followed by government (41\%) and private giving (10\%). The surprising smallness of the private giving by comparison to what is generated from activity revenues hints at a desire for self-sufficiency (Salamon and Anheier, 1997:7).

Salamon and Anheier give examples of the surprising breadth and extent of the third sector:

- $40 \%$ of all hospital patient days and almost all sport facilities in Germany;

- $33 \%$ of all child day care and 55\% of all residential care in France;

- over $50 \%$ of all hospital beds and $50 \%$ of all universities in the USA;

- over $75 \%$ of all universities in Japan;

- Over $20 \%$ of all primary and elementary education in the UK;

- Over $40 \%$ of all residential care facilities in Italy; and

- $40 \%$ of all housing in Sweden. (1997:4)

Jean-Louis Laville, Director of the Laboratory of Sociology at the French National Center of Scientific Research, provides insightful analysis of what he defines as the civil and solidarity-based economy (1999, 2000, 2003). He credits the rapid rise of globalisation pressures as a significant factor in the 'rebirth of nineteenth century-style associations with their insistence on economic action through solidarity'. The dominance of the market economy and the market society is thus contested as people seek alternatives to what they perceive as 
weaknesses and shortcomings of today's society. 'They are in other words, illustrative of economic activities that are in agreement with the principles of justice and equality. Initiative and solidarity are reconciled since individuals are uniting voluntarily to undertake joint action that will create economic activity and jobs, while simultaneously forging a new social solidarity and reinforcing social cohesion' (2003:11).

Laville does not denigrate the power and the place of the market economy. Instead he argues for a more extended definition: the plural economy with three poles:

- The market economy with its emphasis on material interest;

- The non-market economy where the principle of redistribution is governed by the welfare state; and

- The non-monetary economy driven by the principle of reciprocity.

The parallels here to Novak's trinity of systems ${ }^{90}$ are striking. Adapting the tripod concept the three sectors can be presented thus:

FIGURE 3.1

THE PLURAL ECONOMY

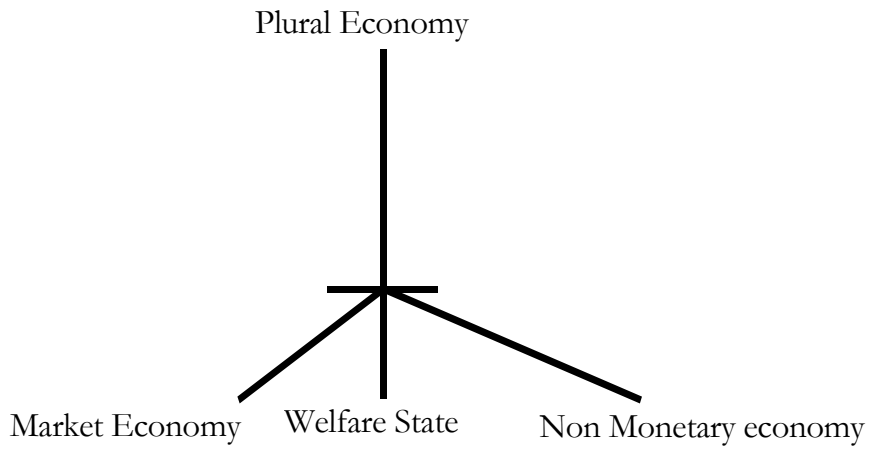

90 See section 2.1.1. 
It is the principle of reciprocity that provides the most insight into why the growth of solidarity-based organizations like social and community enterprises is occurring. The market economy tends to create circumstances where there are winners and losers, a few with extreme wealth, and thus greater alienation occurs. Gaps of availability (for example, surplus ${ }^{91}$ resources of wealth, time and skills) and need thus arise. It is a curious ${ }^{92}$ mixture of selfinterest and solidarity that provides the motivation for reciprocal association: the act of giving (skills, time, resources) benefits also the giver 'through a complex mixture of disinterestedness ${ }^{93}$ and self-interest (Laville, 2003:13). ${ }^{94}$ Laville also notes the paradox of the gift: 'It calls for a counter-gift that takes the paradoxical form of an obligation through which the group or person who receives the gift exercises a certain freedom' (:13) to return (in some beneficial form) or not the gift. The return of the gift, or indeed the freedom not to do so, thus closes the loop of inclusion. A practical example of this principle may be seen in the predominantly positive attitudes to community organisations like the Masterton Trust Lands Trust who channel a significant part of their profits back to individuals and groups within the community. Even though the community at large is the beneficial owner of the Trust and thus rightly can expect to receive some benefit, the receipt of the gift of support creates an 'obligation' of goodwill, in effect cementing in place a positive relationship. ${ }^{95}$

\footnotetext{
${ }^{91}$ Surplus in this sense means those resources that are not required to meet personal and family needs. In a way similar to philanthropy, individuals may seek to employ their wealth or skills to address an area of need that attracts their interest.

${ }^{92}$ Curious because how it occurs is often a complex mixture of circumstance, frequently personal to the time and parties involved.

93 The disinterest here is not a lack of care, concern or commitment, but a desire for no personal benefit. An excellent example of this concept is the Masterton Licensing Trust Act 1947. The Hansard debates at that time sought to emphasise the unique mandate being given to Licensing Trusts: that they should be 'disinterested' in the quantum of profits. 'I is probably true to say that there cannot be a wholly disinterested owner. We believe, however, that substantially disinterested ownership and management is possible and that it is likely to tend in the direction of eliminating that drinking which distinguishes excess from moderation' (Teahan, 1990:51, as quoted in Hansard).

${ }^{94}$ Salamon (2003:!) also supports this view.

95 Any argument along these lines must, of course, be qualified. Rarely is the relationship between a community and its members as simply formed as this. The tides of public opinion rarely flow one way for long periods of time, and conflict and animosity can often be realities.
} 
Laville notes another impact of the global markets. The desire for local or 'controllable' solutions can be seen as a reaction to the sheer scale of many international companies trading in the markets. Thus there seems to be an almost instinctive recognition that some balance is required if 'I personally am not to suffer'. This premise enhances Laville's thesis on the plurality and complementary nature of the economy and society.

Salamon (2003:1-3) extends Laville's explanation for the growth of the civil society sector:

- The 'dramatic breakthroughs in information technology and literacy' have given the poor and disadvantaged greater hope that the conditions of their life may be changed for the better. 'Heightened interest in buman rights' have 'stimulated citizen activism' and 'awakened gender, environmental, and ethnic consciousness'.

- The limitations of the state (bureaucracy and slowness of reaction) and the market sectors (the creation of inequalities through the rich getting richer and the gaps getting wider, and the inability of some people to cope in a competitive world) to provide for all circumstances.

- The pool of educated professionals' that have come to see this sector as the way they can 'make a difference in their societies'.

- Significant organisations (the Catholic Church, western charitable foundations, 'multinational corporations eager to ensure a "license" to operate', and the World Bank) that have come to realise, either for their own ideological or practical reasons, civil society organisations offer benefits.

The growth of philanthropy - 'another golden age may be about to occur' - was the subject of a recent article (July 31, 2004) in The Economist. 'Inequality is the 
friend of philanthropy, and large fortunes encourage individual generosity' (:1) provides further support for these themes as does the OECD paper on Social Enterprises (1999) and the United Kingdom's Department of Trade and Industry publication of July 2002.

While there are a number of authors who attest to the growth of solidarity based organisations that seek to address perceived needs, it is as well to record that not all will be successful and not all will have goals that are laudable. Carothers (1999) cautions and illustrates that more is not necessarily better and there is evidence to suggest that in some mature economies, a plethora of interest groups pursuing their sectional aspirations can choke democracy in favour of 'the rich and well-connected or, more simply, the better organised' (:5). An example of the better organised reaping greater rewards than may fairly and justly be due ${ }^{96}$ can occur in philanthropy. Unless the decision-makers are vigilant and discerning, donations can, and frequently do, favour those with more connections in society. ${ }^{97}$

\subsection{STRUCTURE AND FORM}

The list which follows is intended to be representative and not allencompassing. Its purpose is to place into perspective the range and type of organisations that form the civil and solidarity sector. Some would be classed as community enterprises in terms of the definition provided in section 1.2. Some would at times be. There can be quite often ${ }^{98}$ be a blurring of sector,

\footnotetext{
${ }^{96}$ It should be acknowledged that what is fair and just will often be subjective to the time, place, circumstances and the people involved

97 This is not an idle statement supported more by hearsay than evidence. The author was involved for over 25 years in extensive community support donations programmes which provided frequent examples of this statement. It is emphasised that an inference should not be taken that connections, influence, and good organisation are inherently bad or wrong. That is neither intended nor correct. But vigilance and discernment is desirable. For a wider treatment of this issue see Porter and Kramer (1999) and (2002).

98 The vagueness of this statement reflects the paucity of definitive research on many of this group of organisations. For example, in New Zealand it is not possible to say how many of the 15,253 (as at May 2004: source Companies Office Information Service) charitable trusts may be classed as community enterprises. All have to be charitable in nature to be classed as a charitable trust in terms of the Charitable Trusts Act 1957 but how many operate a business is not known.
} 
and precise categorisation may only be possible if a clear understanding of an organisation's purpose and practice is achieved. The growth of hybrid structures that at times are market orientated, at times state or public service providers, and yet at times solidarity based, is commented upon by Evers and Laville (2004) but such organisations are not a new phenomenon. The Trustee Savings Banks formed in New Zealand over 150 years ago attest to that. Finally to add to this lack of apparent preciseness, Evers and Laville (2004) highlight Kramer's (2004) question in their book of essays on the Third Sector in Europe: Does sector matter? The answer Evers and Laville provide summarises the views of a number of authors: '...organisations develop according to the varying impacts of building principles such as democratic participation, cooperation with users, the degree of embeddedness in local spaces of civil society - or vice versa, the degree that, for example, pure commercial and managerial principles override principles of social and professional action that had shaped social services in the public and third sector' (:6). Values and principles do not belong to any one sector and components more recognised as belonging to one sector, as for example competitiveness to the market sector, cross over and apply to others. Community enterprises, an example of Laville's hybrid organisations, exemplify today that sector matters little in the day to day thrust of operational achievement. ${ }^{99}$

\footnotetext{
99 The question arose at a seminar on community enterprises: how do we know when they are best suited to meet a particular need? Or, phrased in another way, when is a private enterprise structure a better option than say a SOE or community enterprise? That question must have arisen at the time of the design of the Energy Companies Act 1992. A Government official told me that the original intention was full privatisation but such was the outcry of the communities that had been traditionally involved in energy ownership, the legislation allowed for both options. The final outcome of this legislation was overwhelming support for the community model but both existed, frequently geographically, side by side.

The point of this example, and a partial answer to the question, is that it often does not matter, and probably matters less than Government officials would give credence to. The answer should only be accepted as partial because, of course, the wider context of the question is to what extent does structure matter, which has been a source of fascination for many authors. The theorist will debate the question, and the practitioner will find a model that best suits the circumstances; as Eketahuna did with their charitable trust.
} 


\section{- COOPERATIVES}

Cooperatives are one of the oldest forms of structures. Their roots can be traced back to 'our prehistoric predecessors' (Zeuli et al, 1980:1). The origins of the commonly used form today probably date back to $19^{\text {th }}$ century England. The characteristics of cooperatives are voluntary membership, user ownership and control, and distribution of profits back to the members. A world renown example is the Mondragon Coperative Corporation which has its roots in the Basque region of Spain. The Evangeline cooperatives on Prince Edward Island in Canada are another multi-purpose group which operate diverse businesses, for example, agricultural producer groups, funeral homes, taxi, health, and food retail. In the USA, 'more than 900 member (electricity) cooperatives serve 37 million people in 47 states. ${ }^{100}$ New Zealand examples are the Fonterra Cooperative Group, a multi-billion dollar producer and exporter owned by its 13,000 dairy farmers; and Foodstuffs who dominate the grocery markets.

Friendly Societies are a specific form of cooperative. They are a type of organisation that originated from the craft guilds in England in the $13^{\text {th }}$ century. The mutual sharing of risk in fields like savings, insurance, age care and health care products allows for potentially greater individual benefit. ${ }^{101}$ The Southern Cross Medical Care Society is the largest in New Zealand with a membership over 800,000.

In a broad interpretation of the community enterprise definition where its members are classed as a community and their well-being is enhanced by its activities, cooperatives could be classified as part of

\footnotetext{
100 Source: the National Rural Electric Cooperative Association on web-site www.nreca.org.

101 Friendly societies in New Zealand come under the umbrella of the Friendly Societies and Credit Unions Act 1982. As at June 2003, there were 199 friendly societies in NZ with 849,000 members holding funds of $\$ 450$ million and generating income in the last financial year of $\$ 438$ million. Source: Registrar of Friendly Societies and Credit Unions 2003 annual report.
} 
the community enterprise family, but to do so would be quite a stretch. For the purpose of this work, they are seen to be a separate form of organisation, primarily because the solidarity element is, most often, not a core component.

\section{- CREDIT UNIONS}

Credit Unions are prominent in many countries. The World Council of Credit Unions records ${ }^{102} 123$ million people in 84 countries benefit from participation in over 40,000 unions. More properly defined as a cooperative financial institution rather than as a separate structure, they are owned by their members to whom any profits are returned. Thus, they would belong, most often, to the cooperative group rather than community enterprises.

\section{- CHARITIES' TRADING ARMS}

Many charities run businesses. Why they do so may be explained in their statement of purpose/goals and may relate to providing employment, generating revenue, meeting a community need or supporting community charitable projects and organisations. One such example is the Masterton based Trust House Limited, a charitable company that meets the requirements of the Charitable Trusts legislation in New Zealand.

THE CASE OF TRUST HOUSE LIMITED

Trust House define their purpose 'to benefit the communities in which we trade by:

- operating successful businesses that may benefit from community ownership;

102 See web-site www.woccu.org. 
- distributing profits in support of community organisations and events. ${ }^{103}$

The charitable company's 2004 annual report lists 28 business units with 4 of these managed, and thus not owned, for 2 neighbouring Trusts in Hastings and Upper Hutt. Revenue of \$40.9million was generated from these businesses which diversely range from supermarkets, bars, bottlestores, a hotel, retirement home and hospital, and over 500 rental bouses to a golf driving range.

A net surplus (profit) of \$7.203million was achieved for the 2004 year of which $\$ 3.454$ million was distributed back to the community in charitable donations.

Charitable trusts that trade would fit within the definition of community enterprises.

\section{- COMMUNITY ENTERPRISE COMPANIES}

Graham Boyd of the Caledonia Centre for Social Development gives these examples of organisations using the community enterprise company model (2003:2): crèches and day-care centres, leisure and recreational facilities, community and village halls, food outlets and supply services, information technology centres, waste recycling centres, local museums and heritage centres, local radio stations, local regeneration and economic development agencies, community land trusts, community construction enterprises, and local utility providers, for example, water and energy.

Light (power) and water utilities owned by the community are a common feature in the United States of America. For example, the Cedarburg Light and Water Utility is one of 82 such organisations in the state of Wisconsin. While 'dedicated to meeting our customers' needs' they seek to 'make the community a better place to live and work.' Their locally represented board maintain their tariffs lower than neighbouring areas

103 Source: Trust House Staff Induction Book. 
(by 25\%) and contribute significant amounts (over $\$ 2$ million during the past five years) to the city authority to keep taxes lower. ${ }^{104}$

These types of structures would fit within the definition of community enterprises.

\section{- COMMUNITY INTEREST COMPANIES}

'The Community Interest Company (CIC) will be a new form of company designed for social enterprises who want to use their profits and assets for the public good. CICs will be easy to set up, with all the flexibility and certainty of the company form, but with some special features to ensure they are working for the benefit of the community. CICs will report to an independent regulator on how they are delivering for the community and how they are involving their stakeholders in their activities.' ${ }^{105}$

The United Kingdom commitment to social enterprises ${ }^{106}$ is thus reflected in this legislation which took effect from 1 July 2005.

Community Corporations are a title synonymous with CICs. Shuman (2000:83-105) gives a good treatment of their characteristics with examples. One of the most famous is the Green Bay Packers. ${ }^{107}$

By definition, CICs are community enterprises.

- VARIOUS...

The great diversity of forms of organisations in the civil and solidarity sector is represented in the following names that arise in the literature:

\footnotetext{
104 Source: web-site www.cedarburglightandwater.com.

105 Source: web-site www.dti.gov.uk/cics/.

106 See note 7 for an explanation as to why the title community enterprise is more preferable for New Zealand.

107 Nationally (in the USA) and internationally the Packers rarely need any explanation. There are a multitude of web-based articles on them and their web-site (www.packers.com) is informative.
} 
development trusts, community development corporations (CDCs), community development credit unions (CDCUs), community development financial institutions (CDFIs), public interest companies, grass root organisations (GROs), grass root support organisations (GRSOs), community corporations, community lands trusts. Not all may fit within the definition of a community enterprise but all may have characteristics of their components.

\subsection{SOCIAL ENTERPRISES}

In July 2002 the British Government presented a significant policy document titled Social Enterprises: a strategy for success. A foreword by the Prime Minister and an introduction by the Secretary of State for Trade and Industry give weight to its importance.

The document has its intellectual background 'wbile Labour was still in opposition' (Passey and Lyons, 2004:2) and direct linkages to the third way aspirations of the Government. Passey and Lyons (2004:3) identify that the 'link is a commitment to institutional reform' reflected in a 'new mutualism' that would see 'a broader range of institutions'. Thus, in a broad range of initiatives, Labour would also address philanthropy and the voluntary and community sector.

The Prime Minister's words reflect their vision: 'Our vision is bold: social enterprise offers radical new ways of operating for public benefit. By combining strong public service ethos with business acumen, we can open up the possibility of entrepreneurial organisations bighly responsive to customers and with the freedom of the private sector - but which are driven by a commitment to public benefit rather than purely maximising profits for shareholders' (Department of Trade and Industry, 2002). Further on the document broadens the vision: 'socially inclusive wealth creation, enabling individuals and communities to work towards regenerating their local neighbourboods, and helping to develop an inclusive society and active citizenship' are part of their ideals (:7). 
The document is lengthy and exampled throughout by about 40 vignettes of works and organisations in progress. Commitment is further illustrated by the working parties established (8) covering the diversity of (inter alia) legal, regulatory, governance, research and mapping, business support and training, finance and funding, promotion, impact and evaluation. That work continues on although reporting back has occurred on a number of matters. The Social Enterprise Unit within the Department records a number of reports including Guidance on Mapping Social Enterprise (2003), Baseline Data on Social Enterprise across the UK (2005) and a special report by the Bank of England on The Financing of Social Enterprise (2003).

The legislation empowering Community Interest Companies (CICs) which came into force on 1 July 2005 is designed to strengthen and encourage social enterprise.

While the New Zealand Government has reviewed the charitable sector in recent years, this was almost entirely driven by taxation issues, and not by institutional reform as in the United Kingdom. That country's social enterprise initiatives have no parallel in New Zealand.

In Europe they are an integral part of the social and economic fabric, although with different emphasis and importance in each country (DTI, 2002; OECD, 1999; Evers and Laville, 2004).

\subsection{COMMUNITY ENTERPRISES IN NEW ZEALAND}

The definition of community enterprises provided in the introductory chapter contains the following components:

- A business, that is, where trading and enterprise are present;

- The support of a defined community, that is, where the principle of solidarity is present; 
- A defined community which may be geographic and/or a community of interest;

- The precedence of primary community support goals over profit maximisation.

Using these components as a base reference point it is possible to better define the prevalence of community enterprises in New Zealand:

\section{- CHARITABLE TRUSTS}

Those trusts that operate trading enterprises and have charitable status under the Charitable Trusts Act 1957 would be classed as community enterprises. The Eketahuna Community Charitable Trust which is the subject of a following case study is such an example. The prevalence of this type of organisation is not precisely known because of the lack of accurate statistics. It is known that 15,253 charitable trusts were on the register of the Companies Office as at May 2004. How many of these operate businesses is not known although anecdotal knowledge suggests a good number do.

Charitable trusts own, operate or support health clinics, hospitals, hotels, forests, rest homes, gaming lounges, zoos, energy assets, sporting and recreational clubs, museums, property, churches, consultancies and training services and facilities ...the list is far from complete. Regrettably there is no data base that provides even the most basic of analysis. While the recently formed Charities Commission is to address this failing, it will be some years before quality information will be available.

One source ${ }^{108}$ suggested that charitable trusts in New Zealand hold assets of $\$ 20$ billion but that is likely to be a calculated guess with 
limited claims to accuracy.

\section{- LICENSING TRUSTS}

Licensing Trusts were born out of the prohibition era of liquor control with the first Trust established in Invercargill in 1944. They were given a legislated mandate to sell liquor with care in the interests of the public's well-being, and to provide accommodation and eating facilities. ${ }^{109}$ The original legislation contained an enabling provision for the Trust to distribute profits to its community in support of charitable, cultural, recreational and philanthropic purposes. This provision has continued on in the current legislation. ${ }^{110}$

The Masterton Licensing Trust was the second established in 1947 and there followed under omnibus legislation, the Licensing Trusts Act 1949, the establishment of a number of Trusts so that today 22 Trusts trade in various parts of the country. In 2002, they collectively generated sales of $\$ 286$ million, held assets of $\$ 209$ million, achieved profits of $\$ 29.9$ million and distributed community support donations of $\$ 18.9$ million. ${ }^{111}$

The original concept of licensing trusts was that the sale of liquor would be monitored in the Trust's community by the elected representatives of the people - the community well-being factor. With the changes of the years, market conditions now predominantly apply to the sale of liquor. The monitoring role has thus dissipated and the significant point of difference now between the Trusts and their

\footnotetext{
109 See the Invercargill Licensing Act 1944 (since absorbed into the Sale of Liquor Act 1989) and parliamentary debates at that time (reference, Hansard, 1944:17-; 718-).

110 See section 189, Sale of Liquor Act 1989.

111 Source: An address to the New Zealand Licensing Trusts Association conference in Queenstown, June 2003 by the author. The 2002 results were the last compiled collectively and range from the very small (Hawarden in mid Canterbury with sales of $\$ 23,000$ and Parakai in the Auckland area with sales of $\$ 70,000)$ to the largest, Invercargill with sales of $\$ 56$ million.
} 
private enterprise counterparts is the community support (solidarity) programmes each of the Trusts operate.

\section{- ELECTRICITY TRUSTS AND ENERGY COMPANIES}

When the National Government was considering privatising the community-owned energy assets in the early 1990s, the considerable opposition they received from those communities forced them to provide for community ownership under a community trusts framework. The model that resulted under the Energy Companies Act 1992 was the formation of energy companies charged with the responsibility to be successful businesses. Thus no element of community support was envisaged. The Community Trusts, however, a number of which were the sole owners of the energy company that operated in their area, were not so constrained although there are suggestions that vicariously (through the successful business requirement for the energy company owned by the Trust) they may have been (Teahan, 2000).

In 1998 the majority (26 of a total of 35) of the energy companies were community owned. The industry held assets at that time in excess of \$4billion (Ministry of Commerce, 1998). Substantial reorganisation and ownership change has since occurred.

A study of the performance of the energy companies between 19961998 (Teahan, 2000) found that the community trust-owned companies kept their tariffs lower ${ }^{112}$ than their private enterprise counter-parts thus providing a dividend/rebate to each of their community consumers.

112 In 1996, tariffs were 5.69\% lower; 1997, 8.70\%; and in 1998 6.64\%. 
Community Trusts that own energy assets thus can be classed as community enterprises. Their focus of support is primarily their community to whom they seek to return a portion of profits. Their solidarity role is predominantly constrained to returning profits to their customers through reduced tariffs or their equivalent.

\section{- COMMUNITY TRUSTS}

Twelve community trusts constituted under the Community Trust Act $1999^{113}$ hold assets in excess of $\$ 2.5$ billion ${ }^{114}$ and are very active in their communities distributing community support: for example the ASB Trusts distributed $\$ 40.8$ million in the 2004 year. None of the Trusts actively run businesses other than the TSB Community Trust's ownership of the TSB Bank. Instead, they are in the nature of passive investment trusts that distribute their income. Thus, they are not community enterprises in terms of this thesis' definition, with the exception of the TSB Community Trust whose only investment of 100\% ownership of the TSB Bank effectively consolidates that Trust into a community enterprise.

\section{- $\quad$ LATES AND THE LIKE}

A number of local authorities operate trading enterprises (LATES) ${ }^{115}$. 14 airports throughout the country are $50 \%$ or more owned by the neighbouring local authority. 11 Port companies are 50\% or more owned by their regional council or local authority.

113 These Trusts resulted from the restructuring of the trustee savings banks under the Trustee Banks Restructuring Act 1988 and should not be confused with other community trusts formed under different legislation, for example, the energy community trusts.

114 McKinlay (2001) records the assets and community support donations of each of these Trusts. Each Trust's web-site also provides a more current picture.

115 They are a small field of 13, getting smaller as local authorities exit the owning and operating of businesses (The Audit Office, 2000). 
Profits or dividends from these ventures may be used to reduce the rates burden and thus they are on the fringe of being community enterprises. However, the linkages to the community, through the local authority, tend to be more indirect. None have a direct solidarity function.

\section{- SPECIAL PURPOSE}

Schedule 2 of the Public Audit Act 2001 lists a range of 'specific public entities' that may have the characteristics of community enterprises. A number would run trading enterprises; some would be active in the solidarity support of their defined community. An example is the Masterton Trust Lands Trust:

THE CASE OF THE MASTERTON TRUST LANDS TRUST
In 1871 the Wellington Provincial Council passed the Masterton and Greytown Lands
Management Act to take possession of certain unsold and reserved land remaining after the
Small Farms Association was wound up. ${ }^{116}$ That Act, the forerunner of the Masterton
Trust Lands Act 2003, set in place a community enterprise that was to have a significantly
beneficial effect on the Masterton community.
Now over $130 y e a r s ~ o l d$, the Trust's original objectives have little changed. Section 7 of the
current Act provides that the trust lands may be utilised for purposes beneficial to the
community and for public utility. The particular emphasis of the Trust is educational
assistance. One way in which this is effected are grants to tertiary students. All students who
reside in the Trust area are eligible and in May 2005,233 grants of $\$ 600$ were
awarded. ${ }^{117}$
In the 2003 financial year the Trust lands and buildings generated income of $\$ 1.7$ million
from assets of $\$ 23.5 m i l l i o n$. Community support of $\$ 676,700$ was donated from profits of

116 Source: (Henderson, 1997).

117 Wairarapa Times-Age, May 12, 2005, page 3. 
$\$ 876,100 .^{118}$

Recently, the Trust announced that assets now exceeded \$30million, an outstanding return from the 1872 legacy of $\$ 640$.

Of the more than 50 organisations listed in the second schedule only a small number would fall within the definition of a community enterprise.

The growth of the third sector notwithstanding, community enterprises, one form of structure that make up the sector, are not new in New Zealand, dating back almost to the Treaty of Waitangi in 1840. Sporadic legislation over the period since then has assisted their ability to support and enhance the quality of community life. In the latter decades of the 1900s the political climate has moved from enthusiasm (for example, Licensing Trusts in the 1940s), benignity (for example, the energy companies legislation in the early 1990 s and the community trusts in the late $1980 \mathrm{~s}^{119}$ ), to opposition as market driven philosophies were pursued. Today, the political climate is more supportive as Governments throughout the world come to realise that a better balance is required between the three sectors; and better understanding and awareness of the power and effectiveness of the civil and solidarity sector are arising.

Throughout this period in New Zealand, the people's choice of charitable trusts was and is always available. Frequently, the charitable trusts legislation has been turned to as communities sought to protect or enhance the quality of their lives. The great regret is the paucity of information available from official sources on the frequency and scope of charitable trusts as community enterprises.

\footnotetext{
118 Source: Masterton Trust Lands Trust annual report for the year ended March 2003.

119 Although, cynically, a more accurate interpretation may be the legislation occurred in the form it did to solve the problems that arose (for the community assets that existed) as the Government of the day pursued the policy of privatisation.
} 
Chapter 4

\section{METHODOLOGY}

In gaining some distance from positivistic convictions, contemporary thought has made notable advances toward the ever more complete discovery of man, recognising among other things the value of metaphorical and symbolic language.

John Paul II

From Crossing the Threshold of Hope (1994:35)

The introduction summarises the methodological approach as:

- Multi-method, adopting, predominantly, the rigours of the case study as the best vehicle to deliver an understanding of community enterprises;

- Multi-disciplined, embracing, where appropriate, the characteristics of the lawyer, accountant, marketer, politician, economist, planner and strategist, manager and philanthropist; and

- Postpositivist in stance.

The need for the research design to capture the practical world realities and the nature and character of community was emphasised. This chapter extends the initial discussion into a detailed justification why a postpositivist approach was taken, and why the case study is the best method to capture the qualities this research seeks to record.

Thus, the chapter proceeds under the following headings:

- The Research Design; 
- The Nature of Community;

- Positivism and Postpositivism;

- Effective Case Study Research.

\subsection{THE RESEARCH DESIGN}

The process started with the knowledge of the years. Believing community enterprises are a good concept and that they work effectively and efficiently, has not been lightly achieved but forged in the furnace of everyday realities. Working in and with community enterprises for 30 years teaches:

1. The fiscal and market disciplines required by the competitiveness of the marketplace are ignored at the peril of survival.

2. The need to ensure a satisfactory profit and return on investment is constant.

3. Good accountability processes to all important stakeholders, and good governance, define a good community enterprise from one that is regularly addressing pressure points. Ownership requirements are clarified and addressed in these processes.

4. The politics associated with community agitation and personal agendas is rarely comfortable at the time but most often can be managed to the organisation's benefit.

5. Community support (philanthropy) and business enterprise goals comfortably co-exist provided each is recognised for their differing skill needs (at times).

6. The skills vital to successfully operate a community enterprise are not significantly different from those required for private enterprise. The motivational needs may be. 
These factors are not self evident truths. But they do represent good practice. Some are contestable. Some are contrary to the generally accepted 'wisdom'. ${ }^{120}$ For example, Spicer et al (1996) argue that over time politics is detrimental to the economic performance of public bodies, and that the placement of social goals under the responsibility of a separate organisation improves economic performance. Clearly, where the practical beliefs are contrary to the generally accepted wisdom, the body of proof must be more compelling.

The concept of good practice deserves further clarification. Good or the best of good practice can illuminate policy opportunities. In business, as in other fields, what is best practice can be reported in occasional papers and books ${ }^{121}$ but more often, and arguably more effectively and powerfully, by word of mouth. Anderson (1990) highlights the natural tension between good practice, and innovation and inquiry, where one may contest and extend the boundaries of the other.

But these factors, along with much other anecdotal assistance, suggested components of a framework for community enterprises. The literature search, taken in context, either supported or redefined. The constant reference between the two eventually resulted in definition.

A sceptical and questioning attitude helps. Attempting to achieve success by working with and through people teaches the essentiality of trust, a value well supported by the writings of Fukuyama (1995), Peters and Waterman (1982:235-) and Pfeffer (1998). But trust must be grounded in a sceptical attitude. The curious and paradoxical relationship between the two is one of

\footnotetext{
120 As Fischer (1998) notes: 'Historically, the determination whose rationality prevails has largely been decided by those wielding the most influence or power.' Further he argues '...there can be no such as a 'fact" as the term is conventionally understood. Facts, in the natural as well as the social world, depend upon underlying assumptions and meanings. What is taken to be a fact is in effect the decision of a particular community of inquirers who work within a set of theoretical presuppositions to which they subscribe.'

121 The raft of 'excellence' books that followed 'In Search of Excellence' in the 1980s are an example, but there are many other such examples as fashion presents.
} 
those hard won truths that Cowley (date unknown) explains so beautifully. ${ }^{122}$ A sceptical attitude well grounded in trust is inherent in the research design and is embedded in the linkages and feedback loops.

One further contrast had the potential throughout the research to enhance the quality of the final outcome. The competing framework of the prevailing private enterprise model was able to provide a series of questions and tests. Thus, for example, for licensing trusts which compete alongside private enterprise, what was their comparative performance? What did they do that was different from private enterprise? Was the TSB Bank's decision to retain their independent community status justified in comparison to the other community banks who sold out to private enterprise? Why would not private enterprise provide a supermarket and fuel service station in Eketahuna but do so in other (at times, even smaller) rural communities?

Contemporaneously, the literature search was developing a theoretical and philosophical framework for community enterprises. Thus, while practical experience provided the starting point, the literature was clarifying and defining. The research design could now be crystallised:

122 Cowley, in this article published in the Marist Messenger (a national Catholic monthly magazine published since 1929 by the Society of Mary in New Zealand), writes about the 'paradoxical relationship' between strengths and weaknesses, between leadership and self-centred arrogance, the gift of discernment and judgemental attitudes...The quotation was recorded at the time but not the date (approximately 15 years ago). 
FIGURE 4.1

\section{THE RESEARCH DESIGN}

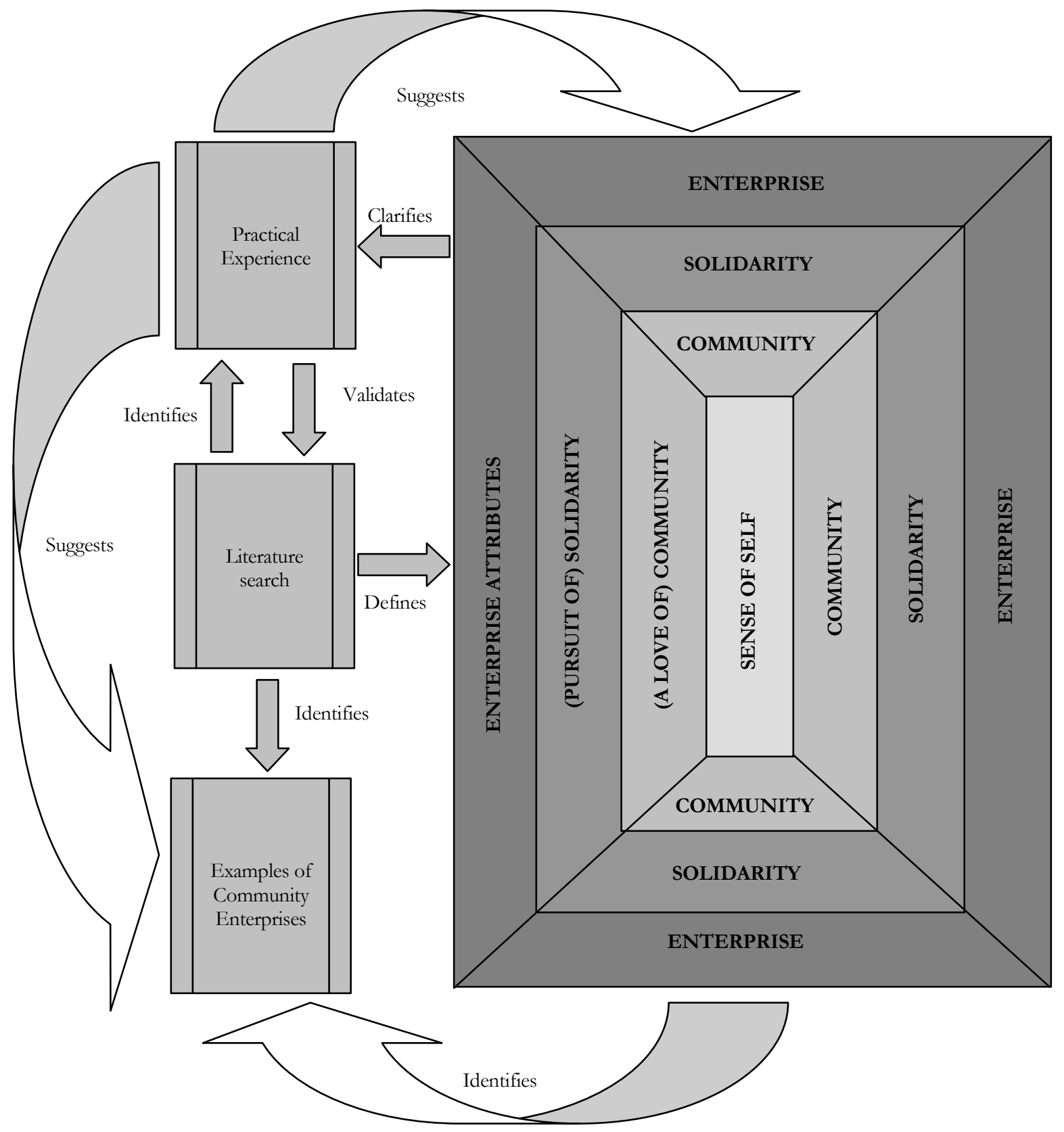

The linkages and feedback loops provide the key to the quality of the research outcome. There is a constant referral and questioning between the 'bank' of 
practical experience, the search for new (to the writer) knowledge from the literature, and the design and testing of the framework.

Practical experience and reason may have provided the starting point but no less important was the definition and identification from other writers exploring componential and related concepts. The 'testimony' of their 'ashes' (ben Shea, 1989) provided frequent encouragement and enhancement. ${ }^{123}$

\subsection{THE NATURE OF COMMUNITY}

The need for the methodology to capture the practical world realities emphasised the requirement for a multi-method approach encompassing a variety of disciplines. But equally important was to capture the nature and character of community; for the concept of community is the single most important point of difference for community enterprises in comparison to other forms of enterprise. As the literature identifies in chapter 2, the uniqueness that is community has been the subject of fascination of writers and researchers over the ages. How then to capture its qualities in the methodology?

Gates (1998:163) gave an early lead: '... our quality of life is dependent on the number of stories we know about the items we use in our daily lives. And (these stories) continue to build into a much larger social and cultural fabric which defines our place and makes it unique.'

Fowler (1991:92) goes deeper: 'We are story tellers, narrative-offering souls, who have stories to tell, stories of our lives, and communities will necessarily reflect this fact. No other road to community is possible, certainly not from philosophical abstraction or the yearnings of intellectuals.'

\footnotetext{
123 ben Shea tells a charming analogy: 'In the process of our journey, we must bend to build a fire for light, and warmth, and food. But when our fingers tear at the ground, hoping to find the coals of another's fire, what we often find are the ashes. And, in these ashes, which will not give us light or warmth, there may be sadness, but there is also a testimony. Because these ashes tell us that somebody else has bent to build a fire, and somebody else has carried on. And that can be enough, sometimes.'
} 
Shore's (2001) entertaining message is accomplished through stories.

Cohen $(1985,2000)$ brilliantly illustrates his central theme of the symbolic construction of community 'as a referent of...identity' (:118) with a series of case studies.

Stake (1995:10) notes that 'much of our gathering of data from other people will take the form of stories they tell and much of what we can convey to our readers will preserve that form.'

Walters and Sudweeks (1996) record both Forester's (1993) and Kaplan's (1993) contention that 'in order for policy analysts to communicate effectively, they must use stories or narratives as primary means of presenting analysis, stories with structure, coherence, and meaning.'

But it was Fischer $(1998,2003)$ who provided the clearest and most compelling arguments for stories and storylines to be the methodology to best capture what community enterprises do: how they function in an 'everyday' way, Toulmin's (1990:27) 'rich perspective' of human affairs. Schmidt (2002:210) termed such stories as 'communicate discourse' where values and shared beliefs are given 'cohesion' (Fischer, 2003:74). As Fischer (2003:75) notes, this approach is not new as witnessed by the powerful parables in the bible.

Hajer (1995:56) describes a storyline as 'a generative sort of narrative that allows actors to draw upon discursive categories to give meaning to specific or social phenomena.' Storylines, states Fischer (2003:87) 'function to condense large amounts of factual information intermixed with the normative assumptions and value orientations that assign meaning to them.' He further asserts (:140): 'without an interpretive narrative that offers an explanation of how things work, social actors have trouble comprehending or synthesizing chains of meanings.' The emphasis Fischer gives to the 'best story' is strong: 'politics in a democratic society...is a struggle for power played out in significant part through arguments about the "best story".' (2003:x) 
Interpretive frames, which Fischer traces to Goffman's (1974) work, have the potential to enhance particular aspects of a policy or subject. Van Gorp (2001:51) defines a frame as 'an organizing principle that transforms fragmentary information into a structured and meaningful whole' by 'select(ing) out some parts of reality at the expense of others.' Their ability to pick up a storyline and frame it to illustrate a key argument is a feature of this research.

Context is critical to meaning: 'it is only through a contextual window that the thick realm of buman experience can be adequately described and researched' (Fischer, 2003:165). Context in the writer's case may be seen in the association between practical experience (the observations of the years), the writings and research of others, and the field research that follows.

Fischer's analogy (2003:166) to the 'story telling' that is the essence of the law courts is helpful in gaining understanding of the importance given to the story 'as a central place in the explanatory forms of the buman sciences' (:164). In the Courts lawyers advance evidence and challenge the evidence of others. A number of stories can be told around a common theme, with different shades of authenticity from which the jury or judge select one (or a combination) that they most believe. As Fischer notes (:166) 'the process is not "scientific", but it is also not irrational'.

The Courts analogy raises an obvious challenge: what is true and accurate and how do we know if the research story being told is worthy of respect and belief?

Certainty in research is the holy grail. What constitutes truth and certainty has been endlessly debated and described, and will continue to be so.

In more recent years much debate has centred round the degree to which the subjective should be allowed to infiltrate a rigorous objective stance to research. As De Leon (1998) records, for many years quantitative research, shaped by modern economics, dominated. "Everybody" (i.e., the large majority of 
political scientists, economists, and policy scientists) seemed to agree that "objective" policy research - that is to say, research based on the rational actor or the economic man and substantiated by sufficient empirical evidence statistically manipulated and displayed - was the only "real" basis by which the policy sciences eventually could aspire to a model of predictive status, and thereby gain status within policymaking circles (DeLeon, 1998). ${ }^{124}$ Fischer (1998) placed that argument this way: The only reliable approach to knowledge accumulation ... (was seen to be) empirical falsification through objective bypothesis-testing of rigorously formulated causal generalizations' (Popper, 1959; Hofferbert, 1990). The degree to which this is valid impacts significantly on the methodology adopted for this research. Thus a discussion on the appropriate epistemological assumptions is warranted.

\subsection{POSITIVISM AND POSTPOSITIVISM ${ }^{125}$}

Positivism may be defined as a philosophical system which holds that every rationally justifiable assertion can be scientifically verified or is capable of logical or mathematical proof. ${ }^{126}$ A corollary is that ideals or moral considerations should not be applied to limit the scope of the assertion. In effect, positivism claims to be a 'value-free' social science approach. Fischer extends (2003:118) that definition:

- '... reality exists as a objective phenomenon and is driven by laws of cause and effect that can be discovered by empirical testing of hypotheses and deductive statements.

- ...inquiry has to be empirically objective and value-free as the laws or generalizations exist independently of social and historical content.

\footnotetext{
124 McCloskery (1985:7-8) lists seven features of this approach. Central of these are: data must be observable; observations must be reproducible; rigorous objectivity is crucial; scientific explanation should be linked to a covering law, and values and morality should be excluded.

125 Also known as empiricism and postempiricism. Some, for example DeLeon (1998), would also interchange quantitative and qualitative as synonyms.

126 The New Oxford Dictionary of English (1998).
} 
- The goal is to find and apply the general principles common to all of the sciences.

- Science and its methods are the only way to obtain valid knowledge.'

DeLeon (1998) quotes Fischer (1995:243) to provide a starting point for a definition of postpositivism ${ }^{127}$ : 'A contemporary school of social science that attempts to combine the disclosures of social and political theory with the rigor of modern science. It calls for a marriage of scientific knowledge with interpretive and philosophical knowledge about norms and values.'

Drawing largely from Fischer $(1995,1998,2003)$ a postpositivist approach pursues:

- Empirical inquiry within a broader interpretive framework;

- A discursive, contextual understanding of social inquiry where ideas move to the centre of policy evaluation;

- An embedment of the empirical in the normative, a complex blend of factual statements (through the eyes of the actors), interpretations, opinions and evaluation. In effect, values are not detached from facts and there is an acceptance that both are conditioned by time, place and people.

- An informal deliberative framework of practical reason;

- A 'rich perspective of buman affairs' through an interpretive narrative; (Fischer, 1998; Toulmin, (1990:27)

- Data examination through conflicting frameworks;

127 But Fischer (2003:121) notes there is no standard definition. 
- A multi-disciplinary and multi-methodological approach 'that opens the door to a more subtle and complex form of rigor.' (Fischer, 2003:132)

'Where you stand can influence what you see' and 'socio-cultural settings give purpose and meaning' (Fischer, 2003:123).

Positivism and postpositivism offer stark contrasts. Both seek relative certainty. Yet one seeks to do so through an exclusion of values and ideals and the other through an apparent license to subjectivity. Can both be right? The short answer ${ }^{128}$ is yes; as DeLeon (1998:147-161) argues: 'a viable middle ground is preferable to either end of the methodological spectrum.' His conclusion is more compelling: 'But in a complex world in which neither idol can be satisfied-perfect predictions are not possible nor are they likely to be believed by policymakers (who have alternative values to weigh or scenarios to consider), and perfect understanding is ephemeral, as any good deconstructionist can affirm - then it would seem foolish to set the two concepts at odds, in a zero-sum game, as opposed to use them to inform and support one another.'

Nonetheless, this thesis predominantly pursues a postpositivist approach asserting that the nature of community enterprise is better suited thereto, where

- Empirical inquiry is mingled with values, opinions and ideas;

- A 'rich perspective of human affairs' (Fischer, 1998; Toulmin, 1990:27) is interpreted through a narrative discursively contextual;

- Practical reason is valued for its insights;

- Data is examined through a multi-disciplinary and multimethodological approach tested by conflicting frameworks.

128 A short answer is desirable because (1) the permutations of a debate thereon seem endless; (2) the debate serves no purpose here but can be pursued independently; (3) the writer, while predominantly pursuing a postpositivist's approach seeks also to employ at times a positivist's stance, for example, 
A challenge to the writer's belief that his research approach is postpositivist may be made on the grounds that it is more 'non-positivist' and 'interpretivist' in orientation (Ryan, 2006). Ryan explains: Interpretivist research (sometimes identified as based on '(symbolic) interactionism' or 'constructivism' - others call it 'grounded theorising' or even 'fourth generation' approaches to social research) is based on the principle that, because life is fundamentally social, the pathway to explanation is via 'understanding' the underlying norms, values and symbols of interaction. Further, understanding is best achieved by members of a community who have internalised the accepted, underlying frameworks and patterns of meaning and action, who know how to interact in that setting, and who are best placed to interpret what is occurring. Researchers adopting this approach seek to become 'participant observers' in the setting under study. After entering the field, they try to become acculturated, an 'insider' and thus able to interpret what's going on. Experienced practitioners are later able to do something very similar by critically reflecting on their past experience as an insider. By distancing themselves as 'researcher' from themselves as 'practitioner', they can use their insider understandings to interpret.'

The vigorous debates on the various merits of qualitative versus quantitative research have generated definitions and shades of meaning that are often 'fervently' (Onwuegbuzie, 2002) advanced and defended by their proponents. The resulting dialogue serves a number of purposes (for example, to advance and enhance both theory and practice) to which the writer does not intend to add, but rather to briefly overview to support this work's assertion that it is postpositivist in stance, while acknowledging that many labels are not precisely defined, and can be subject to shades of interpretation, and even interchange.

That the debates are frequently vigorous, and often tend to unsustainable claims of absolutism, are reflected in the number of articles that seek a more peaceful middle ground, for example, DeLeon (1998), Weber (2004) and Onwuegbuzie (2002).

when comparing the financial performance of a community enterprise with an equivalent private enterprise organisation. 
But it is nonetheless startling how often the same word can be interpreted differently, or even at times singularly contrarily. For example, it is not hard to envisage that Fischer in his explanations of postpositivism (2003:117-138) would take exception to Giddings and Grant's (2007:54) misleading explanation of that subject 'as a more moderate form of positivism' with the 'post signalling a development of positivism'. Fischer $(1998,2003)$ interchanges positivism with empiricism, and postpositivism with postempiricism. Deleon (1998) interchanges quantitative with positivism and qualitative with postpositivism where most would recognise that quantitative and qualitative are broader, generic terms that have generated a raft of sub-fields. Williamson (2006) substitutes interpretivism for postpositivism believing that interpretivism is a broad term that encompasses a number of different paradigms, all concerned with meanings and experiences of human beings.' DeLeon (1998) gives approval to Fischer's (1995:243) temperate definition of postpositivism where, once again, the interchange of words is exampled in the 'interpretive' clarification Fischer provides.

These debates are important in seeking clarity of purpose and definition, and vitally, to advance the quality of research. For these reasons, and to acknowledge Ryan's (2006) challenge, the writer seeks to define his position as clearly as possible, while basing his clarification in the non absolute middle ground of the debate (for one definition of the various schools of thought see Onewuegbuzie [2002:521] who classifies the groups as purists, situationalists and pragmatists). In doing so, the writer defends his position as deliberatively chosen, and joins with Weber (2004:x) in believing that 'many of the alleged metatheoretical differences... between terms 'are spurious and vacuous'. There is wisdom in his belief that 'excellent researchers simply choose a research method that fits their purposes and get on with the business of doing their research. They understand both explicitly and implicitly the criteria their colleagues will use to evaluate their research (xi)'. 
Before providing that statement, definitions of non-positivism and interpretivism serve mainly to emphasise the commonality between the terms and that previously provided in this section of postpositivism:

- While one view of non-positivism may be that it is the reverse of positivism (previously defined at the beginning of section 4.3), its advocates would justifiably assert that it has more depth of meaning than that. Ashworth (1997) describes non-positivism as including descriptive (phenomenological) and interpretative (hermeneutic) research, and discourse analysis, all of which postpositivism is said to include.

- Weber (2004:iv) presents Sandberg's table to highlight the differences between interpretivism and positivism. Interpretivism, he states, has the characteristics that the 'researcher and the reality are inseparable, knowledge of the world is intentionally constituted through a person's lived experience, knowledge claims are defendable', and the researcher's subjectivity is recognised.

The methodology of this thesis must be interpreted from the 'Thanks' at the beginning of this work to the end comment of chapter 10. That is the theme from page 1 , reflected and linked in the quotes opening the chapters, the interspersing of the vignettes, and the selection of the case studies. I am seeking to interpret empirical inquiry, discursively, where my ideas, experience and values are intermingled throughout the thesis. I am doing so deliberatively, with reason, and testing through a variety of disciplines; and, again, attempting to do so in a way that 'richly' describes practices and people.

To reiterate - what I am attempting to do is to take 30 years of living in the world of community enterprises and place it in the context of credible research. Where opinions are voiced, I am comfortable in doing so because the reader should be well aware and warned of my values/opinions approach. 
That is what Fischer $(1995,1998.2003)$ defines as postpositivism. That is what the writer believes best describes the methodological approach.

It is not just the nature of community enterprises that predicates a postpositivist approach. To advance evidence in support of the view that community enterprises are a good concept well suited to the challenges of today's world, a rich description ${ }^{129}$ of how community enterprises actually perform, what they do, why they do it, what communities value and why they will mobilise to protect that value, is necessary. Chapter 2 defines the component parts of community enterprises and their associated contentious issues. The methodology must be able to capture each of these and yet present a collective whole that holistically represents the spirit and reality of community enterprises:

1. The personal sense of self that drives the establishment of community enterprises and the ongoing will and determination that 'fuels' their continuance.

2. The love of, and need for, community association (thus creating its enduring and endearing nature) that makes attractive the form of community enterprises.

3. The solidarity concept that supports community life.

4. The concept of enterprise, comprising economic performance and a desire to use personal skills for the benefit of the community.

5. The contentious issue of the performance of mixed goals.

\footnotetext{
129 Perhaps more commonly termed thick description (Geertz, 1973; Maxwell, 1992:288; Fischer, 2003:150-151; Eisenhardt, 1991:626). Geertz suggests descriptions should go 'right down to the factual base but also to the hard rock.' Geertz's rhetoric for rigour needs to be tempered by Eisenhardt's warning that interesting stories do not necessarily make worthwhile generalisable theory. Sechrest (1996) gives the graphical example of a lens with its greatest thickness 'over the focal point of the case ....with decreasing thickness towards the periphery' and the practical example of a board of directors meeting.
} 
6. The ownership issue and its handmaidens, accountability, governance and politics.

7. The need for profit and satisfactory economic performance.

Before answering how this is to be achieved, a brief discussion of thick description', the craftsman principle and the theory of case study research is desirable to establish a sound foundation for this research's methodology.

\subsection{1 'THICK DESCRIPTION’}

John Paul II's reference to 'metaphorical and symbolic language' in the opening quotation of this chapter is mirrored in Cohen's (1985) case studies. Words, symbols and actions often have layers of meanings and it is the researcher's task to attempt to provide interpretation and 'deep' insight.

Geertz (1973) termed one method of arriving at these meanings 'thick description.' Only through 'detailed descriptions of the social context of the situation' (Fischer, 2003:150) will the depths of meanings be revealed. Denzin (1989:83) lists four characteristics of this approach: the context of the act, its social meanings and intentions, its history and evolution, and a narrative that allows a reader to interpret. Geertz's (1983) classic example is his story and interpretations of cock-fighting in a Balinese village where he reasons the fights represent contests of status between the village men. Cohen (1985:77), too, in his case of the Norwegian Saami and the Alta River protest describes what was really at stake in the proposed hydroelectric scheme was the Saami's ethnic and cultural integrity.

\subsubsection{ANALYSIS AS CRAFT}

A useful analogy is the craftsman principle (Majone, 1989; Fischer, 2003). Majone (:42) notes 'the argumentative model of analysis can seldom demonstrate the correctness of ....conclusions but...produce(s) more or less persuasive evidence and reasonable arguments.' It is in this context the craftsman's ability to know how becomes 
more important than 'knowing that'. 'Since perfection of data is impossible, the standards of acceptance will have to be based on craft judgements...(:47). Like the craftsman at work, judgements are based on the experience accumulated, which is in itself based on learnt knowledge and applicable disciplines. The precepts of a craft can never be fully articulated, but despite the absence of explicit rules a connoisseur has little difficulty in distinguishing good from poor craftsmanship' (:66). In such distinction the policy of analysis adequacy is most important. Majone (:67) helpfully provides criteria for judgement:

TABLE 4.1

PROCESS-ORIENTATED CRITERIA OF ADEQUACY ${ }^{130}$

\begin{tabular}{|l|l|}
\hline ANALYTIC COMPONENT & CRITERIA OF ADEQUACY \\
\hline Data & Reliability, reproducibility, credibility \\
\hline Information & $\begin{array}{l}\text { Relevance, sufficiency, goodness of } \\
\text { fit, robustness }\end{array}$ \\
\hline Evidence & Reliability, admissibility, strength \\
\hline Argument & Cogency, persuasiveness, clarity \\
\hline Conclusion & Plausibility, feasibility, acceptability \\
\hline
\end{tabular}

No matter how rigorously the processes of analysis adequacy are pursued, readers will question how credible is the research story. For a story to most people, no matter how proponents like Fischer, Gates, Fowler or Cohen (who undoubtedly have earned the distinction of craftsman) may laud the method, is still 'an account of imaginary or real people and events told for entertainment' ${ }^{131}$ where the dominant overtones are imaginary and entertainment. In good part that is

\footnotetext{
130 Reproduced from Majone (1989:67).

131 The New Oxford Dictionary of English (1998).
} 
why the story, whether named a discursive process or a case study, has its critics. Yin, who is widely regarded as the standard text for case study research, early in his (2003) third edition addresses that challeng: The case study has long been (and continues to be) stereotyped as a weak sibling among social science methods.' In rejecting that and noting their extensive use (which itself is a significant rejection of the allegation), he reminds the reader and the researcher that 'good case studies are... difficult to do' (:11). But the tag still remains, although to a lesser extent today as their use and disciplines are extended. To overcome that apparently inherent stigma necessitates quality, care and controls in all stages of the (case study) story's production - design, data collection, analysis and report. 'Every discipline' states Kaplan (1964:4) 'develops standards of professional competence' which must be met if researchers 'are to be taken seriously by the profession.' These disciplines and protocols are now canvassed.

\subsection{EFFECTIVE CASE STUDY RESEARCH}

The case study's ability to explain complex real-life phenomena is one of its unique strengths. The types of questions it best answers are 'how' and 'why' (Yin, 2003:7-8) by bringing together a wide variety of evidence including direct observation and interviews. The converging of these multiple sources through rigorous triangulation is an essential feature of the case study approach.

A case has been defined by Yin (2003:13) as 'an empirical inquiry that

- investigates a contemporary phenomenon within its real-life context, especially when

- the boundaries between phenomenon and context are not clearly evident.'

Case studies should not be haphazard. They should start with a research design. This plan should seek to be as clear as possible from the beginning 
and be progressively refined. Research questions and propositions help to focus attention and direction.

Case selection is particularly problematical. Deciding the unit of analysis (Sechrest, 1996:1-7; Yin, 2003:21-26) helps concentrate attention on the thesis' key questions: for example, are community enterprises being researched for their unique contributions and attributes (yes) or is the research issue why is not the dominant private enterprise structure providing what community enterprises undertake (not the primary question but an ancillary issue that needs to be addressed)? Selection bias can be reduced through documentation of selection procedures. Thus evidence should be provided that the cases are representative and any bias is minimal enough to not affect the validity of the findings.

Further validity threats applicable to this research can arise through:

- Cognitive bias (Sechrest et al, 1996:6-2), particularly salience and representation;

- Confirmation bias, the instinctive tendency to search for evidence to confirm the researcher's viewpoint;

- Personal beliefs and prejudices. If they properly have a place in the study then their early identification and justification is desirable;

- Inadequate attention to objectivity that renders replication difficult. Science is in principle replicable (Sechrest et al, 1996:2-4) and the investigator needs to remind himself that the audit trail should be sufficiently strong to allow another to arrive at similar findings;

- An inability to seriously consider rival or competing explanations (Sechrest et al, 1996:11-4; Yin, 2003:137). 


\subsubsection{CASE SELECTION - THE PROCESS ADOPTED}

The selection of case studies to test the framework generated by the literature of chapter 2 and the thesis defined in the introduction and reiterated in this chapter, originated in the 'pool' of community enterprises listed in section 3.4. That 'pool' is not extensive in New Zealand although, very likely, the charitable trusts field is largely hidden from view.

The unit of analysis, the starting point, is community enterprises. To address the thesis they had to be viewed holistically: why they exist, what they do and have done (both successes and failures), what value they deliver to their communities, and how they operate. Thus the focus is the businesses they operate and their performance, the community support they provide (even on occasions why some philanthropic projects were selected for support and others rejected), and the key people that historically and today were motivated (and why) to drive successful achievement. This approach is essentially an answer to the question 'how do they work in practice?' Given the writer's experiences, this was obviously the knowledge area where he had a special empathy and could contribute most. He could also reasonably expect to benefit from 'privileged' access.

Sample size, that is, the number of case studies undertaken, needed to be decided on the ability of the cases to replicate findings. Yin (2003:47) states that this way: Each case must be carefully selected so that it either (a) predicts similar results (a literal replication) or (b) predicts contrasting results but for predictable reasons (a theoretical replication)'. Four literal replications were considered reasonable in the context of the research thesis. A representation from a failed community enterprise was not considered to have any special merit that on balance justified inclusion in the selection. This decision was not arrived at without a good deal of thought and concern. Often failure can deliver knowledge and unique lessons that may not be available from a successful community enterprise. But because there was no evidence of a greater failure rate than for 
private enterprise ${ }^{132}$ and because the thesis has an emphasis on the positive achievements of community enterprises, the original intention to include a case study on the failure of five Wellington Licensing Trusts was dropped. This was a difficult decision and perhaps even a 'line call'. But while a failed community enterprise in a field of six might be a reasonable balance, it was considered not to be so in a field of four. There were other factors that influenced that decision. The writer had a close association and in-depth knowledge of the Trusts, including, in the early 1990s, managerial responsibility ${ }^{133}$. In his considered opinion, politics and both managerial and governance deficiencies were the major contributing factors to their demise. The circumstances thus were unique to those Trusts while common to business failure. Nonetheless, what eventuated is a story that deserves to be told at some future time for the lessons it offers.

The selection process needed to achieve a representative sample of community enterprises in New Zealand. That representation ideally should have these characteristics:

- Geographic spread, that is, metropolitan, provincial and small town New Zealand;

- A spread over the different categories, for example, licensing trusts, charitable trusts;

- Coverage over different business enterprises, for example, hospitality, health, energy;

\footnotetext{
132 There is no statistical data on the failure rates of charitable trusts. Licensing Trusts' failure rate is not dissimilar to that of private companies (see speech presented to the 2003 annual conference of Licensing Trusts, Queenstown by the writer) and the performance of the community owned energy companies as a group was better than their private enterprise equivalents (Teahan, 2000). A greater failure rate than private enterprise would logically place added emphasis on why, and thus more justify inclusion of a failed example amongst the community enterprises selected for study.

133 The managerial responsibility ended in 1994 when the five Trusts chose a different path (in effect, the then status quo) from that recommended (the Trust House model).
} 
- Reflect the different emphasis given to community support programmes;

- A spread of size from the small to the large;

- Be successful over time, that is, have an embedded success and survival over a number of years.

LATES were eliminated from the range of choices early on in the selection process. They have limited features of community enterprises and almost no solidarity role.

The search for an appropriate representation from the field of charitable trusts was made more difficult by the paucity of statistical information. This is the area where Laville's and Salamon and Anheir's third sector growth would be hidden. There was anecdotal (newspaper files, internet search engines, word of mouth) information available but growth and size remains opaque.

From the beginning of the research one case attracted and when the searches that were available were exhausted, and nothing more compelling arose, the Eketahuna Community Charitable Trust was selected. Its choice had a number of benefits. It was a wonderful example of almost spontaneous community commitment, much in the nature of Shore's (2001) examples. Further, it contained all the key components of community enterprises Cohen's (2000) community reaction when their sense of self is attacked, a strong community spirit, business enterprise, solidarity, mixing of goals, good governance and distinct community ownership. Additionally it had the counter-factual issue of why would private enterprise not provide?

Among the community trusts there was only one choice, that of the TSB Bank, the only Trust with a trading enterprise. But it was an outstanding case representing success over a long time frame, provincial New Zealand, large in size and containing all the components of the framework. Comparisons could 
be made to other trading banks and to the counter-factual possibility offered by the eleven other community banks who had chosen a different path.

The energy companies and trusts had been the subject of a year long research project in 1999 by the writer. They exercised limited philanthropy in the traditional sense but most often supported their communities, some outstandingly so, through reduced (electricity) tariffs. They reflected the components of the framework to varying degrees (enterprise - strongly, community spirit - variously, solidarity - in mixed fashion) but were constrained by their legislation to operate as successful businesses. The significant factors in excluding them from the cases selected were these constraints and the recent research.

The special purpose organisations had quite limited characteristics of community enterprises although the Masterton Trust Lands Trust met all criteria. It had significant business interests (although entirely rental), a long life, and was actively involved in the Masterton and Wairarapa communities with extensive community support programmes particularly in education. It would have been a good choice but for an over representation of Wairarapa cases.

Licensing Trusts were always of special interest given the writer's background, their competitive fields of interest (thus exampling their ability to survive alongside private enterprise models), their history of existence (over 60 years) and limited research record. The first Trust, Invercargill, attracted as a choice particularly because of its importance in the Southland community. Like the TSB Bank, this was a very successful community enterprise, and since this was a focus of the thesis, its inclusion in the final selection was an easy choice.

The Trust House group of community enterprises based in Masterton while a good choice because of their diversity of business interests, their transition from one business interest to multi, their length of history, and their extensive community support programmes would have been a good choice for a case 
study but for the closeness of the writer's involvement over many years and an over representation of studies based in the Wairarapa. Instead this group was the source for a series of vignettes to example particular aspects of community enterprises.

To provide a representation of metropolitan New Zealand, the two Licensing Trusts in West Auckland offered the possibility of a unique circumstance, that of community polls which reflected the decision of the electors of those Trust areas to limit competition and in effect subsidise their community enterprises. While the unique polls could be classed in the nature of an outlier, the nuances of the polls offered possible fascinating insights into the nature of community, the status of the privatisation debate and another possible answer to Cohen's question (2000:104): What produces such (community) vehemence and assertiveness?' Thus a representation of the two West Auckland Trusts in the final selection was justified by the unique answers they may provide. They also had reasonably large business enterprises and large community support programmes.

The final selection would have these characteristics: 
TABLE 4.2

\section{CASE STUDY CHARACTERISTICS}

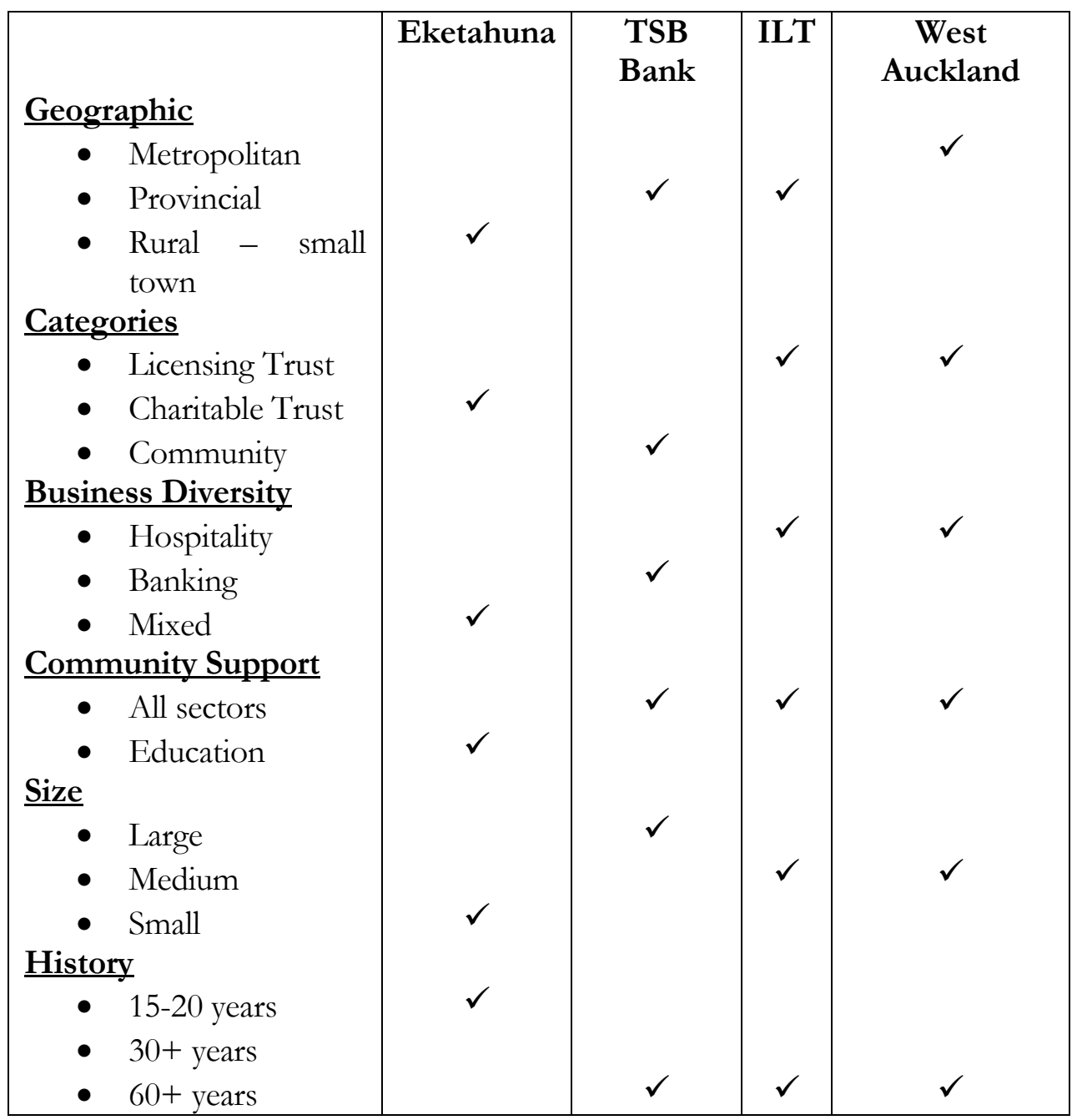

\subsubsection{DATA GATHERING}

Each case study was a lengthy process. It had to be to capture the essence of how the community enterprise worked in practice. The process began with a search for the written word about the organisation and its community. Thus:

1. Library records produced historical publications, research papers and occasional articles; 
2. The organisation provided historical, promotional or explanatory publications;

3. Annual reports and accounts were read and analysed;

4. Minutes (except for the TSB Bank and TSB Community Trust) were read to obtain a 'feel' for what the Boards discussed and decided;

5. Newspaper archives (via Google and Newztext) were searched and articles read for a number of years. Where 'clippings' files existed in the organisation, they were searched. In Eketahuna's case, the two local newspapers' (Wairarapa Times Age and the Bush Telegraph) archives were also searched.

From these extensive records a list of issues were drawn up. The bounded context of these issues was the framework and the contentious issues described in chapter 2. This stage of research was a 'seeping' process, of becoming embedded in the community enterprises' work and written culture (as distinguished from the cultural impression gained from being 'there' within the organisation). The key public people of the case study were also identified by this process.

Written contact was then made with these key people, usually first the Chief Executive and the Chairman, seeking approval to visit and undertake interviews. From these replies voice contact was made and often these discussions generated further names for interviews.

A list of 6-8 names for interviews was then compiled and each written to for permission to interview. These people were community leaders in one form or another ${ }^{134}$ who were selected for their ability to know more about the community enterprise and the community. Following their acceptance a further letter was sent listing the interview questions and attaching an

1346 were Mayors, 4 District Councillors, 12 Chief Executives, 16 Chairman/Presidents. 
Information Sheet for Interviewees and a Consent (form) to Participate in Research, both documents approved by the Human Ethics Committee of Victoria University. Times for interviews were then arranged.

The recording of the interviews was direct onto a laptop computer through Power WMA Recorder software. This allowed for unlimited play-back options with a sound track of excellent quality. The interviews followed the pattern of the previously provided research questions but often loosely so. A relaxed, semi-formal loosely structured approach was taken. This allowed for a discussion format that was most often friendly and supportive in nature. The interviewees, given their status, had extensive knowledge and it was rarely difficult to tap into this 'bank'. An atmosphere of goodwill was almost always apparent and this allowed freedom to explore associated issues as they arose in the discussion. Thus, while the provided questions were a framework, many other issues and much information was generated during the interviews which lasted from $20+$ minutes to an hour plus. On occasions another key name would consistently arise and after scrutiny, an interview would be arranged by the same process.

The interviews were an important part of the evidence triangulation. They often provided leads and thoughts for further research. But their most important role was to support (or not) the written evidence, and of even greater significance, to identify the 'feel' (the culture) of the organisation and community. All towns, communities and organisations have a culture. It can be elusive and variable. But it was deemed desirable to capture this spirit (which may not be positive and supportive) so that, if at all possible, it may be imparted to the reader to give added credibility to the nature of the community enterprise. Other methods complemented. Walking around a community and visiting key sites (for example, in Eketahuna, the Domain, the War Memorial; in Invercargill, Stadium Southland, the Civic Theatre, Queens Park; and their equivalents in New Plymouth/Taranaki and Henderson/Waitakere) gives a feel for the place which becomes more certain 
as you talk to its people in cafes, shops, motels, airports, and fuel stations. Since most casual conversations have greater components of being negative and critical (the rates are too high, the weather's bad, the Prime Minister, or some other politician, has 'lost' it), it was not difficult to balance out the (at times) effusive stories of the community's leaders. The writer's residency in two of the communities (Wairarapa and Taranaki) and regular visits to Invercargill and West Auckland also helped to understand and capture the character of the community.

In all, 46 interviews were recorded covering 1708 minutes.

Where additional information was required or some fact verified, other interviews, not recorded, were held. Some of these were of a similar length to the recorded interviews but more often were brief, a few minutes only to verify a fact or facts. For these, notes of the key points were taken.

A diary record was kept of all interviews, insights, facts and views. The notes and the diary were helpful as a record to revisit and to follow up on the insights. The audit trial was thus also evidenced. A (bulky) file was compiled of key documents, for example, annual accounts and reports, newspaper articles, market research.

All recorded interviews were played back a number of times with summarised notes taken on the first occasion. These notes were checked against the written evidence where necessary and where conflict of accuracy occurred, further checking was undertaken.

The draft report of each case study was referred to a number of people for comment - supervisors, associates with particular expertise and to all interviewees. The latter group was asked in writing to satisfy a validation process. Only a small number (12 compared to the 46 interviewed) made comment but the letters were framed to emphasise the importance of this 
process, and to note that should no comment be made the writer would assume comments and views expressed were acceptable to the interviewee.

\subsubsection{CROSS CASE ANALYSIS}

Each case seeks to capture the 'spirit' of the community enterprise under study. It focuses on how they work in practice under the structure of the components of the framework design in chapter 2 and addresses the contentious issues defined in that chapter. Chapter 9 completes this process with an analysis across all four case studies. This may be portrayed by adapting Yin's representation (2003:50):

FIQURE 4.2

\section{CASE STUDY DESIGN AND PROCESS}

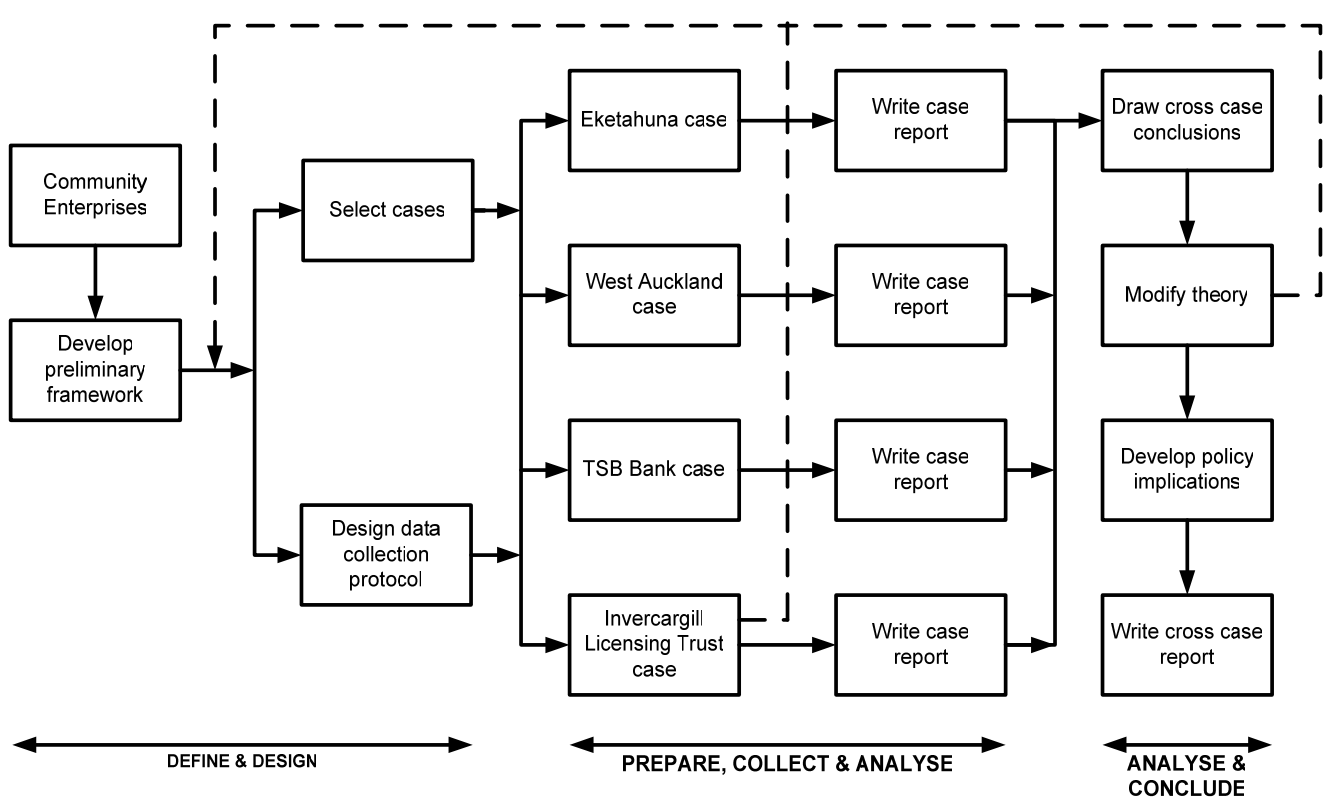

The cross case analysis seeks to benchmark the four cases against the preliminary framework that arose from the literature review in chapter 2 . The four components schematic that was generated from that review itself was further 'broken down' to 21 underlying themes or shades of meaning. The 
data of the four cases is thus examined through the lens of these 21 themes through a multi-disciplinary and multi-method approach, and where practical reason is applied for its insights. Thus, Geertz's (1973) 'thick description' approach better allowed Majone’s (1989) 'craftsman' principle to be sought.

\section{SUMMARY}

The postpositivist, multi-disciplinary, multi-methodological approach presented in this chapter may simply be described as that which best suits the circumstances of this thesis. It is a 'real life' approach, attempting to best capture how community enterprises work in practice. The purist may object to this 'real life' description challenging that other approaches may also claim that they represent what is real, that the term is in any event vague, and what is real and factual may be dominated and influenced by the 'eye' of the writer. It is in answer to these contests that the writer seeks not to withdraw and hide his experiences. They are the starting point. They have been challenged by the writings and research of others, and the experiences of all that form part of the four chapters that follow: their stories, their realities and their community enterprise worlds.

The practices and processes listed in this chapter have been rigorous and demanding. They have attempted to include a little of the disciplines and characteristics of the lawyer, the accountant, the marketer, the politician, the economist, the planner and the philanthropist as the community enterprise practitioner would experience them in their world. That there is a little of each and little concentration of one reflects the reality that the practitioner may at times be all of these.

A little of each is not a comfortable position for the writer to be in. Spread thinly, the opportunities for challenge are greater. At times it would have been tempting, had the thesis been different, to concentrate on one component, say accounting performance, the writer's initial discipline. But to do so would be to risk failing to capture what is special about community enterprises. 
More so than most other forms of enterprise organisation, they are multipurpose. They seek to fulfil solidarity goals to enhance the well-being of their community through (business) enterprise pursuits. In this form they are the community representation of the individual. The individual pursues financial reward so that they may fulfil an often almost inexhaustible list and range of goals. That rich and varied life is naturally extended into community enterprises and that is why they are an easily conceived and understood concept. They are a natural extension of the individual. Nothing other than a richly described, but inevitably methodologically fragmented, approach will capture and explain this character.

That is both the strength and weakness of the adopted approach. 
Chapter 5

\section{EKETAHUNA NEW ZEALAND}

\section{A CASE STUDY OF SMALL TOWN SURVIVAL}

This study began in August 2003 and was completed in February 2004. It attempts to capture a little of the remarkable resilience and determined spirit of this small community. Eketahuna has no particularly remarkable natural or tangible feature. It has some nice resources: the Domain, camping ground and golf course for example; and some good services: the Health Centre, Library and Community Centre for example; but it is a very small village and a passer-by may be forgiven for thinking that time has passed it by. Beneath the veneer, however, is a jewel symbolised in the study by Margaret Parsons's words: 'we can do that', and in the Bush Telegraph editor's question: 'where do you have a Christmas street parade that nobody turns out to watch? Eketahuna - they're all participating.'

A revisit to the town in August 2005 produced the impression that improvements had occurred and the community was going through better times. Many more houses had been painted; there were new fences and sheds/garages, at least three new businesses in the main street and one new house. But the frequent presence of piles of firewood around the town showed this was a pastime to supplement incomes. Population had stabilised (580 as at 30.6.2004, up 1 from 2001), against the trend of neighbouring Nireaba-Tiraumea (down $1.0 \%$ ) and the Tararua District (down 3.3\%). ${ }^{135}$

It was an impressive sight.

The 130 Eketahuna residents overflowed the supper room at the Community Centre, itself the result in the mid 1960s of impressive community fundraising and support. It was Thursday, 1 August 2002, a cold winter's evening. But the atmosphere could not have been more welcoming, even though this was a meeting called primarily so that those present might commit their personal money to build a community service station. A little less than 15 years

135 As provided by Statistics New Zealand, 23 August 2005. 
previously, a strikingly similar public meeting 'to discuss the feasibility of opening a discount store in Eketabuna ${ }^{136}$ had generated a turnout of $150^{137}$. This is a small community with a town population in 2001 of $579^{138}$.

These two remarkable events reflect the community's determination for its separate identity to survive, and its self-worth and pride. They also provide examples for other small communities. Eketahuna residents, by their actions, would say that, although the pressures brought by a rapidly changing world often force the concentration of services like supermarkets, large stores, shopping centres and hospitals, into the centres of large population, these pressures do not inevitably mean the demise of small-town New Zealand.

But the lessons from the 'Eketahuna model' are also wider than that: they help illuminate why (and when) community ownership is an attractive option.

This case study is not just about community pride and determination, of which there is plenty, but more importantly, it is about an awareness of market forces and a common-sense intelligence - street smarts - that is uniquely clever in its simplicity. This case study details the events that led up to and followed those meetings mentioned above. It examines why the community ownership model was chosen, and why private enterprise would not provide, as well as presenting an example of another small community where a different option was pursued in the face of similar circumstances.

This study draws upon semi-structured, open ended interviews with the key community leaders ${ }^{139}$; analysis of newspaper archives, minutes, annual reports

\footnotetext{
136 Public notice advertised in the Bush Telegraph, 13 October 1987.

137 As reported in the Wairarapa Times Age, 17 October 1987.

138 In addition, the surrounding rural areas of Nireaha and Tirumea had a 2001 census population of 1161. For most purposes, the people of these areas would see Eketahuna as their immediate community. But the diverse nature of community today would find that definition limiting. For many, their shopping and dining centre would most likely be Palmerston North, a city of 72,033 people, $60 \mathrm{~km}$ to the north, or Masterton, the largest town of the Wairarapa with a population of 19,497, $40 \mathrm{~km}$ to the south.

139 These interviews were recorded.
} 
and accounts, leases and other legal documents, and correspondence files; and participant observation ${ }^{140}$, to discover, explain, and validate Eketahuna's story. The methodology framework and justification is detailed in chapter 4 but it is perhaps important to emphasise here the necessity, recorded by a number of authors (Yin, 2003; Stake, 1995; Garson, 2001), of ensuring a rigorous triangulated ${ }^{141}$ approach to validation. The key leaders interviewed also reviewed the draft report as did four associates for balance and content ${ }^{142}$.

What follows is a description of Eketahuna and environs, how the supermarket and petrol station were established, the pivotal role of the Eketahuna Community Charitable Trust, the necessity and effectiveness of the community's activism, why private enterprise was ineffective, and the example of Pirinoa that took a different path.

\section{EKETAHUNA: SETTING THE SCENE}

Two historical publications record the early days of establishing Eketahuna ${ }^{143}$, and it is Peter Best who crafts an enduring compliment:

'The pioneering spirit is still strong in our community. We are a people of determination and achievement. We are not afraid to go it alone and get it done.'

\footnotetext{
140 The author participated in some of the events described herein. While not an Eketahuna resident, he was present at the 2002 public meeting, and attended two meetings of the steering committee. He was also CEO of Trust House Limited which has operated the supermarket from 1996, and thus was the tenant of the Eketahuna Community Charitable Trust (ECCT). He was not at any time, however, part of the team that instigated and implemented the 'Eketahuna model'.

141 Multiple lines of inquiry are converged to validate and strengthen the evidence.

142 Thus, eleven in all.

143 Adcock, Irene. (1973) A goodly heritage; Eketahuna and districts 100years, 1873-1973. Eketahuna Borough and County Councils. Best, Peter. (2001). Eketahuna: stories from small town New Zealand. Masterton, NZ: Wairarapa Archive.
} 
Eketahuna rests on a rise above the Makakahi River. It is a small village ${ }^{144}$, not pretentious, just a short distance from the Tararua Ranges, and nestled within well established dairy, sheep and cattle country. To drive through the town on State Highway 2 takes merely a minute. It is an older town. Most streets have empty sections, and there are no houses of recent construction. It is a mixture of 1950s style state houses, charming little cottages, and older 'prestige' homes. Eketahuna is neither seedy, nor wealthy ${ }^{145}$; it is not a town in decline but one which has seen better days.

There is no bank and no ATM, but there are two hotels, and a radio station. The craft and coffee shop opposite the large kiwi that once resided at the entrance to the Mount Bruce National Wildlife Centre, is of recent times. On the junction of the roads to Masterton and Alfredton is the War Memorial and Hall recording the area's commitment to world peace; 83 lives in World War 1 and 21 in World War 2. The playground and pool just off the main street has the St Cuthberts Anglican Church in close proximity. Behind the new Gasoline Alley service station is an excellent 18 hole rural golf course.

The spacious, solidly permanent Community Centre is on the other side of the main street, but again close by are the Eketahuna (Chartered) Club, the Bowling Club, the Health centre and the Sacred Heart Catholic Church. The road to Alfredton is also the road to the Domain, the home of the Rugby, Cricket, and Tennis Clubs, and the School.

The Domain is an attractive sporting centre, well cared for on the edge of the town and thus set amongst the adjacent farms. Here too, is evidence of a committed and resourceful community. The Rugby Club, which attracts

\footnotetext{
144 This definition is Peter Best's. He draws the distinction between the English village, where he spent his early years, and the town: 'Life is slower in a village. There are real characters here - identities that are well known and accepted as individuals. There is a lot of good humour.' Interview 22 September 2003.

145 The 2001 census records median income in Eketahuna at $\$ 12,900$. The Nireaha-Tiraumea area comparison is $\$ 25,400$ (NZ $\$ 18,500$ ). Unemployment was $11.7 \%$ in Eketahuna, $1.4 \%$ in NireahaTiraumea, and $7.5 \%$ in NZ. $19.7 \%$ of Eketahuna residents had a post school qualification, compared with $27.7 \%$ for Nireaha-Tiraumea, and $32.2 \%$ for NZ.
} 
players from throughout the region, won the Wairarapa premiership in $2003^{146}$, an occasion that was well celebrated by the wider Eketahuna community, and a source of much pride.

Even more remarkable, and again reflecting the community's ability to 'punch above its weight ${ }^{147}$, the Eketahuna Schoolgirls team won the National Milo Shield cricket competition in 2000. That a small country school with 157 pupils $^{148}$ could travel to Auckland and win the final received much publicity.

This, then, is a montage of the township and its environs, necessarily incomplete but representative of the community and its achievements. For a small community, it is remarkably well resourced.

\section{A NEW SUPERMARKET}

It was July 1987 and the town's only supermarket, A.H. Herbert \& Co Ltd, in existence for nearly a century, was closing. Newspaper reports at that time reflect the community's concern. It was Margaret Parsons, a retailer and long time resident, who initiated the response. ${ }^{149}$ A group of like-minded citizens met, called a community meeting which enthusiastically supported the need for a supermarket and elected a steering committee. The sequence of events which followed is listed in appendix 1.

The concept was simple. The community would advance monies on debentures either of $\$ 500$ or $\$ 150$ per individual, a property would be bought and outfitted, and a manager employed. Debentures would be repaid in time through a ballot system from the profits. A charitable trust (the Eketahuna

\footnotetext{
146 And also 2004 and 2005.

147 John Monaghan interview 16 September 2003.

148 These are the 2003 numbers but the school states the roll would have been much the same in 2000 . This is a primary school catering for children from age 5 to 12 , and the numbers to select from would be only a small percent of the total.

149 'I saw an article in the Dominion about the Takapau community establishing a discount store, so I thought - why can't Eketabuna do that?’ Interview 3 September 2003
} 
Community Charitable Trust - ECCT) would be established as the legal entity representing the community. With the exception that it was quickly realised that the trust had little experience to operate a supermarket and therefore a change to a lease format was desirable, ${ }^{150}$ that is what eventuated.

The community advanced $\$ 38,480$ in 143 debentures. By 1991 half of that had been repaid, and today the balance of $\$ 8730$ represents a permanent donation by those residents who do not require their debenture repaid. The property purchase, outfitting and stocking initially cost approximately $\$ 96,000$, with the shortfall met by bank borrowing, quickly repaid when the first lease became operative. ${ }^{151}$

Today, the original store area has been extended to include the adjacent building (purchased by the ECCT in 2000), and the business now incorporates the original 4 Square supermarket and town milk run, a Hammer hardware franchise, a full service liquor bottlestore, and the NZ Post shop and mail centre. It is a successful business. ${ }^{152}$

\section{THE PHOENIX SERVICE STATION}

In the early hours of Friday, 15 June, 2001 the sole petrol station in Eketahuna burnt down in a spectacular fire. Newspaper reports ${ }^{153}$ noted that one of the impacts of the fire was the loss of 10 jobs and 3 businesses. The more immediate concern for most residents was how were they to obtain their fuel with the nearest pumps now $25 \mathrm{kms}$ away in Pahiatua. That need was not to be met in Eketahuna until 20 months later.

\footnotetext{
150 As managers, the operating risk was in effect the community's. The lease system not only placed the business risk with the lessee, it also reduced the need for capital. Stock and fittings would be owned by the lessee in future.

There have been only two lessees, with Trust House Ltd, a community owned company based in Masterton, the current lessee since 1996.

${ }^{151}$ ECCT annual reports and accounts.

152 Confidential access to Trust House Limited's records confirm that a small but good profit, and a high return on investment, has been made each year.
} 
Initially, the Palmerston North-based owner promised to rebuild but complications soon arose. The fuel supplier, Shell, was not interested in supporting any such proposal. ${ }^{154}$ Time drifted on despite intense community interest. Two local business brothers expressed an interest in rebuilding the station, and relocating on the burnt out site, ${ }^{155}$ but after extensive investigation, and locating a supplier, they flagged away any interest in fuel supply. Thus, community activism had to provide.

The timing and sequence of events is shown in appendix 1. The service station cost $\$ 229,700$. It was financed by 166 interest free community debentures raising $\$ 138,700^{156}$. A grant of $\$ 50,000$ was provided by the Tararua District Council ${ }^{157}$ with the balance coming from other community trusts' grants, or from the ECCT's own funds. Notably, despite a good deal of effort and encouragement, Government would not help. ${ }^{158}$

A long term lease was entered into on attractive terms with a private operator, who, as with the supermarket, outfitted and stocked the service station, and now runs the business and thus takes the risk normally associated with that. ${ }^{159}$ In effect, the community, through its legal arm, the ECCT, provides a subsidy

\footnotetext{
153 Wairarapa Times Age 15 and 18 June 2001.

154 Bush Telegraph of 3 July 2001, and confirmed by Warren Fisher, present operator of the service station in Eketahuna. The previous owner, Peter Day, states that the Shell rep told him of Shell's lack of interest in rebuilding "as the ruins were smouldering." (Discussion of 19 November 2003.) The old tanks needed replacement, and the threshold feasibility models of the petrol companies demanded volumes greatly in excess of that which Eketahuna had been pumping.

155 The Rowden brothers, owners of Rowden Automotive Ltd, eventually bought the site, and built workshops thereon. A portion of the site was sold to the ECCT.

156 While the number of debentures total 166, with joint donations (usually married couples), 240 names are on the list. Included are 8 businesses or Trusts, and 6 clubs/organisations.

157 As Shaun Lissington records (interview of 24 September 2003), this was not an easy decision for the Council to make, in part because a commercial operator was involved. The grant was for economic development and justified so as to retain and attract people to what is the southern entrance to the District.

${ }^{158}$ Letter of 1 October 2002 from the Minister for Industry and Regional Development. This followed a number of discussions and correspondence with the local MP and Government Ministers and officials.

${ }^{159}$ John Harman, chairman of the ECCT: 'Private enterprise is less likely to invest in small communities. By taking balf the risk away, we make it more likely (that they will do so)'. Interview 17 September 2003.
} 
to encourage and sustain the service station. Its reasons for doing so are discussed further on in this study.

\section{THE SPIRIT OF COMMUNITY}

In both instances, community ownership was not the preferred option. ${ }^{160}$ Only when the private enterprise options had been exhausted, did the community pursue the alternatives. Thus, community ownership was first of all dependent on private ownership not being available.

The community actively worked to encourage private enterprise. With the supermarket, interest was declined by Foodtown Supermarkets Ltd ${ }^{161}$ (now Progressive Enterprises (NZ) Ltd) after the closure of AH Herbert \& Co Ltd, itself a long serving privately owned company. Shell and three other petrol companies $^{162}$ declined to be involved after the fire. The long absence of a service station and the high profile given to the situation ${ }^{163}$ was a constant reminder of a business opportunity, should it be viable.

A strong spirit of community is desirable if a community wishes to consider the option of establishing a community enterprise. Such a spirit is pivotal to its success, in much the same way that an equivalent private business's success is dependent on the commitment of its owners or its agents. But community spirit is 'deeper' than individual aspirations. ${ }^{164}$

The Eketahuna spirit is often noted, and frequently notable. The interviewees were asked to define its characteristics so as to better understand why the community mobilised to provide a supermarket and service station

\footnotetext{
160 As recorded in the five interviews with Dianne Anderson, Margaret Parsons, John Harman, Shaun Lissington and John Monaghan; and the Central Districts Farmer edition of April 2003.

${ }^{161}$ Letter of 3 November 1987.

162 So stated by Peter Day in the discussion of 19 November 2003.

163 Newspaper reports in the Bush Telegraph and Wairarapa Times-Age.

${ }^{164}$ For a treatment of these issues see sections 2.1.3 and 2.2.2.
} 
Spirit can be defined as 'those qualities regarded as forming the definitive or typical elements in the character of a ...nation, or group... ${ }^{, 165}$. What those qualities are, was difficult for all interviewed to describe. There was no one factor. Community spirit can change from time to time, as circumstances and needs change. The components of the Eketahuna spirit may be drawn from the pioneering families, their hard life and the fact that they, and their forbears, had to work diligently for what they achieved. A good number of those pioneering families remain, and the original hardships bred strong, committed individuals. The community is small and somewhat isolated, and, although it has lost much, there is a stubbornness not to lose more. The town has a name that mocks small town life, and thus the community fights back. There is a strong sense of self-belief, born out of necessity.

Are any of these components exclusive to Eketahuna? Clearly, no; many small communities could compile much the same list. It is the combination and sum of components that perhaps takes you closer to why this community has achieved what it has; and these are as diverse, intense and extensive, as the individuals that comprise Eketahuna.

In Eketahuna, as in other communities, ${ }^{166}$ there is a core group of people who are at the centre of most events. ${ }^{167}$ The success of the Rugby Club, and the schoolgirls cricket team, can be traced to a small group, one of whom is usually the dynamic leader. ${ }^{168}$

\footnotetext{
165 The New Oxford Dictionary of English.

166 Clubs, sporting and others, are a good example of the dynamics of community. Invariably, their success in meeting their goals is dependent on the commitment and enthusiasm of a small group of people. The literature on social capital also is helpful to understand why some communities have a richness of life, and others do not. A good contemporary example is the community representation, and community boards disestablishment issues, being considered by the Tararua District Council. Much greater numbers have attended the community consultation meetings in Eketahuna than in Pahiatua and Dannevirke, both of which have significantly larger populations.

167 One interviewee, Shaun Lissington, a Tararua District Councillor, suggested this may be 12 in Eketahuna.

168 The need for, and presence of, strong community leadership is discussed in chapter 9 in relation to the four studies in chapters 5-8.
} 
In summary, while the spirit of community is strong in Eketahuna, it is not unique in the sense that it can not be replicated elsewhere, as frequently it is when communities celebrate success, or come under pressure from adverse events. ${ }^{169}$ An example of the first would be Southland's support for their champion netball team, the Southern Sting; a not so pleasant example of the latter would be Featherston's coming together as a community on the recent murder of a young child.

\section{WHY WAS COMMUNITY OWNERSHIP A GOOD OPTION?}

The reasons why community ownership of the supermarket and service station was attractive to Eketahuna residents are summarised in Table 1, and explained in what follows.

TABLE 1

COMMUNITY OWNERSHIP : ATTRACTIONS FOR EKETAHUNA

\begin{tabular}{|c|c|c|}
\hline & ATTRACTION & MEASURED BY \\
\hline & Community was committed & $\begin{array}{l}\begin{array}{l}\text { Number and amount of } \\
\text { debentures }\end{array} \\
\text { Sales per head of population }\end{array}$ \\
\hline 2 & Spread of risk & $\begin{array}{l}\text { Stability of lessee } \\
\text { No lessee failure } \\
\text { A Resident's risk is small }\end{array}$ \\
\hline 3 & Community profits & Annual accounts \\
\hline 4 & Philanthropy support & Scholarships and grants \\
\hline & Assets accumulated & Annual accounts \\
\hline
\end{tabular}

169 Why communities mobilise to meet threats or needs is discussed in section 10.3. 


\begin{tabular}{|ll|l|}
\hline 6. & Involvement of community & $\begin{array}{l}\text { Number and amount of } \\
\text { debentures } \\
\text { Public meetings turn-out }\end{array}$ \\
\hline $7 . \quad$ Survival of community & Population statistics \\
\hline $8 . \quad$ Individual benefit & Access to services \\
& Price v. alternative costs \\
& Property prices \\
\hline $9 . \quad$ Greater control & Landlord rights in lease \\
\hline
\end{tabular}

\section{A COMMITTED COMMUNITY}

While the planning groups for both projects were undoubtedly committed to ensure a successful outcome, the public meetings, and more powerfully, the individual debentures, brought a personal level of involvement from residents. Because their money was involved, it was 'theirs'. Thus, even though fuel and groceries might be cheaper in Masterton and Palmerston North, a central theme of the interviews was that there was a greater loyalty to the Eketahuna services than if private enterprise had provided.

The validity of that can be measured in sales per head of population compared to (as equivalent as possible) alternative towns. For the supermarkets a valid comparison is possible. ${ }^{170}$

Greytown (urban population of 1998) and Featherston (urban population of 2325) were the towns selected. In all three cases only the urban population

170 The same comparison was not pursued for the service stations for two reasons. Access to the information would depend on the goodwill of three private owners, and while that was possible, the short time frame of operating for Eketahuna would suggest that exercise may be best carried out some time in the future. The new operator at Eketahuna, (Warren Fisher, a person with long and extensive industry experience) advised (discussion of 6 November, 2003) that his fuel volumes were at an annual level one third higher than those of the previous operator, this despite the lack of a fuel card, and without the Shell fly buys incentive, both of which have a significant impact on sales. 
has been used in the calculations. ${ }^{171}$ Greytown, like Eketahuna, has one supermarket. Featherston has two, one privately owned, and the other, like Eketahuna and Greytown, owned by Trust House Ltd. All three Trust House premises have a 4 Square Discount franchise with Foodstuffs Ltd, and thus are operating at a similar pricing structure.

After adjusting to best ensure sales are directly comparable, ${ }^{172}$ annual sales per head of population in Eketahuna are 31.61\% greater than Featherston, and $34.63 \%$ greater than Greytown.

It may be argued that because the Eketahuna supermarket has a Hammer Hardware and NZ Post franchise, rather than the more limited hardware and post accessories that are part of a more standard supermarket, that the comparisons are not like to like. This argument has only limited validity, partly because the NZ Post and Hammer Hardware sales are not large, and partly because there are compensating services and advantages Greytown and Featherston have over Eketahuna; for example, Greytown has a bakery and deli. If these Post and Hardware sales are totally excluded from the Eketahuna sales (which would be an excessive over compensation), their sales per head of population would be $20.27 \%$ greater than Greytown, and $17.56 \%$ greater than Featherston.

Another possible impact that may distort comparisons would be visitors to the towns. If Eketahuna had a larger 'stop off' traffic count, or was a more popular tourist destination, then sales comparisons would be inflated.

\footnotetext{
171 If any one of these communities has a greater usage from the rural area than the others, then selecting only the urban population would have a degree of unfairness in the comparison outcome. There is no known reason why this would be so. The communities are all in the Wairarapa, and all are the immediate economic centre of their surrounding area. Thus it is believed the comparison premise is valid.

172 Sales figures have been provided confidentially by Trust House. For this reason, only percentages are recorded. These have been calculated by dividing total annual sales for an equivalent year (year ended 31March 2002) by the population. Liquor sales in the three Trust House supermarkets have been included. For the private supermarket in Featherston, sales were estimated (based on a knowledge of trading volumes).
} 
Greytown is a popular destination, both for day visitors (predominantly from nearby Wellington), and longer stays. It has the best choice of restaurants and cafes and the more settled climate. Featherston, at the bottom of the Rimutukas, is the gateway to the Wairarapa, and would be the next most popular visitor town of the three. Eketahuna has no motel accommodation, and the hotels are old. Further, it has few facilities to attract visitors. Thus, this impact is more likely to accentuate the gap between the three towns in sales to their residents.

Demographic spread may also distort the validity of comparisons. Older people are more likely, through mobility limitations, to purchase in their local community. Greytown (22.7\%) has the highest proportion of their population over 65, compared to Eketahuna (15.5\%) and Featherston (13.2\%). The latter two comparisons are likely to be somewhat balanced out by Eketahuna's (26.4\%) greater per cent of their population under 15 when measured against Featherston $(24.0 \%)$. It is unlikely, therefore, that differences in demographics explain the sales patterns.

Thus, there appears to be a strong correlation between community ownership in Eketahuna and increased sales.

\section{SPREAD OF RISK}

One of the attractive features of the 'Eketahuna model' is the two-layered spread of risk. Its effect is that the business risk is initially incurred by an independent operator. The community, through the ECCT, acts as landlord, and provides an attractive lease rental to the lessee. It still incurs a degree of risk (the loss of rental) should the business fail, but it is more remote than that of the operator, and it has the normal legal remedies of a landlord. The attractive rental also better ensures the operator will succeed. ${ }^{173}$

173 Or, in another way, as the Central Districts Farmer reported on its front page in the April 2003 edition: 'The turnover in smaller places is too low to interest the major players, but if you remove the capital cost of 
Thus, the ECCT does not have the difficulty of acquiring the specialised skills necessary to successfully run a retail operation. The chances of incurring operating losses are therefore reduced.

A debenture holder has the potential to lose his investment if the business fails, a new lessee is not able to be found, and the sale of assets achieves less than their cost. However, the accumulation of funds (see appendix 2), the size of debentures (largest $\$ 2000$ ), the ECCT’s policy to repay over 5 years with the first repayment in 2003, and the current success of the businesses, all serve to limit that possibility.

\section{THE COMMUNITY RECEIVES PROFITS}

The ECCT has consistently generated profits through rents and interest and, as at 30 September 2003, accumulated equity of $\$ 193,856$. Treating the 1989 and 2003 years as outliers ${ }^{174}$ and therefore not representative, the return on equity for the period 1990-2002 was a healthy 11.0\%. Appendix 2 records key results from the annual accounts.

An ancillary benefit is that these profits, and the improving financial position, have enabled the Trust to provide scholarships to its community. First granted in $2001, \$ 14,500$ has been returned to the community in this way.

\section{SECURE ASSETS TO USE AGAIN}

Total assets have increased to $\$ 341,754$ as at 30 September 2003 . This allows the community to benefit from an asset base that is a security for other ventures. For example, the profits from the supermarket venture were able to be reinvested in the service station. Similarly, future profits can be used in new projects, currently under consideration, to benefit the community.

purchasing the premises it becomes viable ... for an independent operator to lease the premises because (doing so) more than halved the capital investment required.' Quoted from John Harman.

174 The start up costs of the supermarket and the service station distort results. 


\section{A COMMUNITY INVOLVED}

There is a body of literature that argues that mass society today alienates and distorts. Edelman (2000) suggests '... (the) layers of social organisation that exist between individuals and the large economic and political institutions, are weak; this therefore leads to serious and individual pathologies.' Gates (1998) warns of the 'grotesque inequalities' created by modern capitalism and quotes Thomas Jefferson's foreboding that a disengaged citizenry could be democracy's undoing. It is Gates too who maintains that it is a simple truism that we are likely to be 'better stewards of all those systems of which (we) are a part.'

A sense of pride and self-worth is more likely to come from what we successfully do, than what we observe. We can stand prouder if people are involved in helping their community. "175 An empowered and enabled community is, potentially, a powerful force, more likely to effect the inclusion which is the other side of alienation.

John Harman, Chairman of the ECCT, best summed up the outcome of a community fully committed and involved: We have worked out that local people donated $\$ 123$ for every man, woman and child. If Auckland had the same level of loyalty, commitment and motivation, they could fund a superb roading system ${ }^{176}$

SURVIVAL

There is a momentum in the health of a community. Just as creeping decay will eventually bring about demise, adding, or sometimes even retaining, one business will eventually create its own irreversible force. That theme was

\footnotetext{
175 Interview Dianne Anderson 22 September 2003.

176 Central Districts Farmer, April 2003 edition, who also cited that his comments were recorded in the NZ Herald, and TV News. If the region's population of 1740 had been used for the calculation, $\$ 80$ would be more correct, and $\$ 240$ if the town's population was the base. With a population of 1.6 million in the Auckland region, that would equate to sums of $\$ 128$ million, or $\$ 384$ million. The figures of themselves are of little importance but the analogy is a clever way to contrast what the Eketahuna community has achieved.
} 
constant amongst the interviews. Where essential services are under threat, the community is under threat. 177

One measurement of how well a community is enjoyed as a place to live is its population trends. It should be acknowledged that in many ways this is an imperfect measurement, because so many influences are reflected therein. For example, employment is dependent on the economic times, and since this is predominantly a farming community, all the influences that impact on farming also impact on the community population. The trends towards greater mechanisation and contracting out, rather than direct on-the-farm employment, have brought falling population in many parts of rural New Zealand. The timing of the amalgamation of smaller rural holdings trend can affect comparisons between districts.

Imperfect as it is, population nonetheless gives a snapshot of Eketahuna compared against other farming communities.

TABLE 2

POPULATION TRENDS

\begin{tabular}{|l|r|r|r|r|}
\hline AREA & $\begin{array}{r}\text { Census } \\
\mathbf{1 9 9 1}\end{array}$ & $\begin{array}{r}\text { Census } \\
\mathbf{1 9 9 6}\end{array}$ & $\begin{array}{r}\text { Census } \\
\mathbf{2 0 0 1}\end{array}$ & $\begin{array}{r}\text { Movement } \\
\mathbf{1 9 9 1} \text { to 2001 }\end{array}$ \\
\hline Tararua District & 19854 & 19068 & 17859 & $-10.05 \%$ \\
\hline Eketahuna town & 714 & 642 & 579 & $-18.91 \%$ \\
$\begin{array}{l}\text { Nireaha and } \\
\text { Tiraumea }\end{array}$ & 1293 & 1251 & 1161 & $-10.02 \%$ \\
Combined & 2007 & 1893 & 1740 & $-13.30 \%$ \\
\hline
\end{tabular}

177 Interview with John Harman. 
Clearly Eketahuna has fared adversely by comparison with its neighbours. The township population is down 18.9\% between 1991 and 2001. The surrounding rural area of Nireaha-Tiraumea has fallen $10 \%$ over the same period, the same percentage as that of the Tararua District. Neighbouring districts of Masterton $(0.6 \%-)$, Carterton $(0.5 \%+)$, and South Wairarapa $(2.1 \%-)$ have all fared better by comparison.

The fall in population over that of the surrounding district could be in the order of 60-65 people. Reasons why this has occurred are likely to be as varied as the individuals who have left. Perhaps only through contacting all might a pattern emerge. One suggested ${ }^{178}$ cause was the number of houses that have been moved from the town in the last few years as residents of wealthier areas sought to gain from the low priced Eketahuna houses. More generic answers include the lack of employment opportunity and poor farm commodity prices for much of the 1990s. ${ }^{179}$

A theoretical question logically flows from Table 2. Is there a point at which the businesses are no longer viable if population continues to fall? Pirinoa's experience described further on in this study suggests that communities with much smaller populations can sustain viable businesses. The ways in which communities can reinvent and sustain themselves are as expansive as the human imagination. Logically, however, a falling population would pressure the existing cost structures of the town's businesses.

INDIVIDUAL BENEFIT GREATER?

Individuals are 'resourceful, evaluative maximisers, responding creatively to the opportunities the environment presents' (Jensen and Meckling, 1997). Accepting that this is so with qualifications (for example, people will commit great energy for

\footnotetext{
178 Margaret Parsons during a discussion on 28 November 2003. She recalled 16 houses removed in the last 10-12 years. At an average household of 2.5 persons, this has a potential impact of 40 residents.

179 The comparisons to Invercargill and their fall in population $(10.55 \%$ or 5,877 people from 1996 to 2001) are striking. Both areas are greatly reliant on farming incomes. Notably the resurgence in Southland was underpinned by improved commodity prices.
} 
a cause they believe in, as those whose names are recorded on the War Memorial evidence), why did such a high percentage of the community contribute their own money, interest free, for both the supermarket and the service station?

If an individual has an investment in a community - their home, business or farm - then it makes sense to protect that by ensuring the availability of essential services which may help retain and even attract population. Property prices of course respond to demand. If the population is falling, then demand is likely to be less. Logical self-interest is thus a likely variable in explaining Eketahuna's community investment behaviour.

As it turns out, house prices in Eketahuna have not kept pace with sales in the Tararua district or New Zealand over the period 1992/93-2002/03. Compared to 10 years earlier, the average sale price for the 12 houses sold in the year ended June 2003 was $\$ 47,290$, an increase of $4.25 \%$. The average increase for the Tararua District was $7.83 \%$, and for New Zealand, $64.60 \%{ }^{180}$

This is not surprising given the earlier discussion of population trends, for many of the same factors which determine population movements will also contribute to flat housing prices. What might the local population and housing price trends have been without a supermarket and service station? It is not possible to say, but the fact that Eketahuna residents continue to express strong support for their community enterprises suggests that their investments in these projects were motivated by more than the usual impulse to protect property values. In addition, there is some evidence to suggest that many residents and the community leaders take a long-term and holistic view of their town's fortunes. Support for the service station and the supermarket

\footnotetext{
180 This information is sourced from the quarterly Residential Sales Summaries of Quotable Value. The 1992/3 year was the first period Eketahuna sales are shown separately, and thus has been taken as the base comparative period. For Eketahuna, 7 sales occurred that year at an average sale price of $\$ 45,360$. In the Tararua district the average sale price that year for 221 properties sold was $\$ 67,360$; for NZ, the average sale price was $\$ 94,470.10$ years later, the comparative sale price for Tararua was $\$ 72,640$, and for NZ, $\$ 155,500$.
} 
are only two pieces of the larger survival and development puzzle, and patience is required to see the flow-on effects. ${ }^{181}$

Another factor propelling investment may be personal cost and benefit. If an individual advances say $\$ 1000$ to the ECCT so that the service station can be provided, then the loss of interest, after tax, is in the order of $\$ 40$ per year. It would be reasonable to assume that a good number of people would rationalise that loss would be recouped if a special trip to Pahiatua, $25 \mathrm{~km}$ away, was no longer necessary to obtain fuel. That rationale would not apply to those farmers who are able to have tanks supplied on their farms.

The same rationale of benefit outweighing cost would apply to the products available in the supermarket.

\section{GREATER CONTROL}

By owning the assets, the community is better able to intervene if services are not satisfactory, although these interventions are limited to their rights as landlord. This prospect of greater control over the future of their community is in harmony with Shuman's (2000) advocacy for greater local self reliance and thus less dependence on companies owned and managed from outside the community.

\section{SUMMATION}

Eketahuna has gained, by their activism, a profitable supermarket and service station, assets and an annual income able to be used for other projects and philanthropy, knowledge, and a sense of accomplishment, greater selfreliance, and more control over their future. But have they better ensured the survival of a quality of life they enjoy? Their ability to address, and solve, key issues, and their success in punching above their weight would suggest they

181 The introduction to this study gives a 2005 update that suggests reversal of the previously adverse population trends may be occurring. 
have. The downsides from their actions do not appear to be great. Residents may have foregone some income through the debentures. But their emotional and practical commitment to the supermarket and service station is notable. However, critically, the fall in population during the period 1991-2001 would indicate a precariousness that further time must elapse before a more definitive judgement can be reached on the success of the community's initiatives.

\section{A DIFFERENT PATH}

Pirinoa is a country community $7 \mathrm{~km}$ from Lake Ferry on the Palliser coast. The town is small - 6 houses, a hall, garage, school, play centre, a rugby field, and a general store that proudly advertises its establishment in 1882. In 2002, the owners of the general store at their cost installed fuel tanks and a forecourt. In comparing this case with Eketahuna, the obvious question arises: why is it possible here for a private operator to provide?

The investment cost at Pirinoa was about one quarter that of Eketahuna. ${ }^{182}$ Fuel used to be pumped at the garage nearby but when new tanks became necessary the garage owners opted out and the store added the facility to the services they provided. By doing so, they achieved efficiencies ${ }^{183}$ in much the same way that Trust House Ltd merged a number of services into the Eketahuna supermarket to achieve profitable volume.

As in Eketahuna, lessees operate the store. The motivation for the landlords to purchase the store in 2001 and to commit to the fuel supply financing, was more complex than investment return. Among these were a love of the community they had come to after a working life throughout the world in senior executive positions, and an appreciation that in a complex and inter-

\footnotetext{
182 The fuels available for sale are limited to regular and diesel. There is no cover over the pumps. Thus it is a smaller facility, but suited to the market available - residents that stretch to the fishing village of Ngawi and Cape Palliser, recreational fisherman, and holiday makers at the Ferry.

183 Information provided by the lessees in a telephone conversation 14 November 2003; and the owners in an interview on 1 December 2003.
} 
related world, quality of life must be protected at a local level. They sought a modest return on capital, with potential for improvement as profits improve, and that is being achieved.

Like Eketahuna, a 'subsidy ${ }^{184}$ is being provided in Pirinoa, only this time it is by private enterprise owners rather than community residents.

A key factor for this study is the different solutions to the same issue - how to provide essential services. The two examples highlight different outcomes in the differing circumstances. It is not difficult to arrive at other examples where the same or similar outcomes could occur; for example where community ownership is the structure to provide a health centre in one area, and private ownership in another. Fukuyama's (1995) ' $80 \%$, ${ }^{185}$ and the literature on privatisation, suggest that in most circumstances, private enterprise will profitably provide. In other circumstances, community ownership is an attractive option whenever the community can bring resources and commitment to make the business more viable.

\section{CONCLUSION}

It was Saturday, 9 August 2003. In driving through Eketahuna it was very clear that here was a community deeply committed and involved in an event important to the town. Yellow and black colours were everywhere - in the shops, on the main street and even the kiwi had a yellow and black scarf. Goalposts were in the roundabout by the War Memorial. Later that

\footnotetext{
184 The subsidy is in the nature of higher returns foregone, and, perhaps much more importantly, the pragmatic and extensive experience of the owners that is translated into a successful operation in a number of essential ways - for example, the selection of the 'right' lessees to operate the store, and good management and accounting.

185 Fukuyama (1995:17) asserted that '...the edifice of free market economics is, to repeat, about eighty percent right... Substantial empirical evidence confirms that markets are indeed efficient allocators of resources of resources and that given free rein to self-interest promotes growth.' While Fukuyama gives no evidence to support his ' $80 \%$, it is similar to Birdsall's and Nellis's (2002) findings that privatisation has a success rate of $2 / 3$ to $4 / 5$ in improving a firm's performance. But the many qualifications need to be noted. See also Megginson and Netter (2001).
} 
afternoon, at the game ${ }^{186}$ in Masterton, it would seem the whole town had turned out.

This spirit ${ }^{187}$ is a factor in why Eketahuna has a community owned supermarket and service station today and why the first has operated successfully for 15 years. But it is not just this spirit of community that has made this happen. It is the mix of time, circumstances, and people. Private enterprise was always the first option and, given this pragmatic and flexible community, it may be an option sometime in the future should profitability of the services improve to the point where subsidies are no longer justified.

But for today, Eketahuna residents are enjoying a range of benefits they would not have without their own activism: two essential services, assets being accumulated for further ventures, and philanthropy returned to the community.

Thus in the Eketahuna circumstances, community ownership was an attractive option because:

- private enterprise would not provide;

- the services sought were important to the community;

- there was a strong spirit of community;

- the community would support through its initial investment;

- the community would continue to support through its purchases;

- the benefits outweighed the costs;

186 The final of the Wairarapa rugby premiership.

187 The Editor of the Bush Telegraph posed me this question: where do you have a Christmas street parade that nobody turns out to watch? 'Eketabuna - they're all participating.' 
- the community would be more self-reliant;

- the community would be able to exercise greater control over its future;

- assets would be accumulated as a base for other initiatives;

- community philanthropy became possible. 


\section{APPENDIX 1}

TIME-LINES

SUPERMARKET

\begin{tabular}{|c|}
\hline AH Herbert closes July 1987 \\
\hline $\begin{array}{l}\text { Takapau article seen September } \\
1987\end{array}$ \\
\hline $\begin{array}{c}\text { Foodstuffs approached September } \\
1987\end{array}$ \\
\hline Visit Takapau September 1987 \\
\hline $\begin{array}{c}\text { Group of citizens meet October } \\
1987\end{array}$ \\
\hline $\begin{array}{l}\text { Community meeting - Steering } \\
\text { Committee formed October } 1987\end{array}$ \\
\hline $\begin{array}{c}\text { Debenture scheme promoted } \\
\text { March } 1988\end{array}$ \\
\hline Building purchased March 1988 \\
\hline ECCT formed March 1988 \\
\hline Store opened October 1988 \\
\hline$\frac{1}{\text { Lessee appointed July } 1989}$ \\
\hline$\stackrel{1}{ }$ New Lease THL March 1996 \\
\hline $\begin{array}{c}\text { Liquor wholesale merged March } \\
1996\end{array}$ \\
\hline$\frac{1}{\text { Shop Extended March } 2000}$ \\
\hline $\begin{array}{c}\text { Hammer Hardware franchise } \\
\text { added August } 2000\end{array}$ \\
\hline $\begin{array}{l}\text { NZ Post franchise added } \\
\text { May } 2001\end{array}$ \\
\hline
\end{tabular}

\section{SERVICE STATION}

Fire destroys 15 June 2001

Owner promises to rebuild (but later opts out) June 2001

Gasoline Alley agree to supply late 2001

\begin{tabular}{|c|}
\hline $\begin{array}{c}\text { Rowden Bros opt out of fuel } \\
\text { supply early } 2002\end{array}$ \\
\hline Rowden Bros buy site March \\
2002 \\
\hline
\end{tabular}

Community group meets May

2002: petrol station priority

\begin{tabular}{|c|}
\hline Lessee agrees to operate July \\
2002 \\
\hline
\end{tabular}

\begin{tabular}{|c|}
\hline Public meeting supports \\
August 2002 \\
\hline $\begin{array}{c}\text { Tararua District Council grants } \\
\$ 50,000 \text { August } 2002\end{array}$ \\
\hline Debenture scheme raises \\
$\$ 138,700$ mid-late 2002 \\
\hline
\end{tabular}

Government refuses support October 2002

Tanks go in December 2002

Opening February 2003 
APPENDIX 2

ECCT PROFITS AND ASSETS

\begin{tabular}{|c|r|r|r|r|}
\hline $\begin{array}{c}\text { Year Ended } \\
\text { 30 September }\end{array}$ & $\begin{array}{r}\text { Scholarships } \\
\text { Awarded } \\
\mathbf{\$}\end{array}$ & Profit & Net Equity & $\begin{array}{r}\text { Total } \\
\text { Assets } \\
\mathbf{\$}\end{array}$ \\
\hline 1989 & & -495 & -495 & 80,238 \\
1990 & & 3,591 & 3,096 & 47,484 \\
1991 & & 2,874 & 5,969 & 25,910 \\
1992 & & 2,656 & 25,444 & 40,067 \\
1993 & & 2,693 & 28,137 & 42,667 \\
1994 & & 2,774 & 30,911 & 40,654 \\
1995 & & 3,586 & 34,497 & 43,825 \\
1996 & & 3,909 & 38,407 & 47,828 \\
1997 & & 2,058 & 40,464 & 50,538 \\
1998 & & 4,666 & 50,130 & 60,389 \\
1999 & & 4,229 & 54,359 & 63,720 \\
2000 & & 5,532 & 59,892 & 69,252 \\
2001 & & 3,260 & 63,079 & 72,278 \\
2002 & 6,500 & 4,966 & 68,045 & 196,865 \\
2003 & 6,000 & 6,129 & 193,856 & 341,754 \\
\hline
\end{tabular}


Chapter 6

\section{COMMUNITY-}

\section{MORE POWERFUL THAN FREEDOM OF CHOICE? ${ }^{188}$ A CASE STUDY \\ OF THE WEST AUCKLAND COMPETITION POLLS IN FEBRUARY 2003}

This study was started in September 2003 with the first draft completed in March 2004. Supervisory comment was received in May and the revised study was sent to the six interviewees for validation in September and October 2004. Two associates also reviewed the draft during those months.

Licensing Trusts in New Zealand have experienced a mixed relationship with their communities over their 60+ years of history. Trusts began with idealism and great enthusiasm. But frequently this ebbed, sometimes to disdain, as a variety of factors - poor performance compounded by operational and equity issues, sometimes an arrogance to service and community expectations - depreciated the concept. As Trusts adjusted to these expectations and as they matured and their community support programmes blossomed, they enjoyed a renaissance to where today the great majority are respected as a substantial and integral part of their community.

In the best tradition of opinionated editorials ${ }^{189}$ there could be no doubt where The New Zealand Herald stood:

In reality, trusts became unpopular with most New Zealanders because they succumbed to the normal stultifying consequences of smallness and monopoly. Their return on investment was poor, their accountability weak and their service to

\footnotetext{
${ }^{188}$ The title was suggested by such a statement in the UMR research report of June 2003 which summarised the views of 6 focus groups and a telephone survey of 800 West Auckland residents on the polls and the Trusts.

${ }^{189}$ Editorials of February 17 and 28, 2003. The first two paragraphs are from the first editorial titled End trusts' stultifying monopoly five days before the poll closed, and the last paragraph from the second titled Close eye needed on trusts just after the poll result was disclosed.
} 
consumers dismal, the trusts serving up booze barns, slack service and inferior financial management. Almost everywhere, grants to community causes were more mirage-like than munificent.

The vast majority of New Zealanders long ago saw through the warm furzies that underpin the trust concept...

The difference (between companies in competition and a public monopoly) is that one declares a profit paid to investors and the other bides its private benefits in the form of a fatter payroll, easier working conditions and a more comfortable existence for managers and trustees.

The strength of feeling reflected in the language chosen presents an ironic epitaph for a remarkable circumstance. At first appearance, they were polls of citizens deciding if beer and wine may be sold in supermarkets ${ }^{190}$, but the polarisation that occurred and the poll result give notable leads how communities view 'big business ${ }^{191}$ and community owned organisations; and the status of the debate, and balance, between individualism (as reflected in the market economy) and community.

Competition polls under the Sale of Liquor Act are remarkable events. ${ }^{192}$ The citizens $^{193}$ eligible to vote in a defined area choose whether their community-

190 As will be clarified during this study, the ramifications of a poll under section 215 of the Sale of Liquor Act 1989 are wider than liquor being sold in supermarkets.

191 An often derogatory euphemism for capitalism or private enterprise and which was used during the lead up to the poll.

192 The author was not able to find evidence of similar polls elsewhere in the world, despite an extensive internet search, and questioning. It would be far too sweeping to say there are none, particularly because the potential logically exists to hold similar polls on a range of products or services.

193 While it is the voters who decide the outcome of a competition poll, it is unlikely that without the very significant support, both administrative and financial, of the supermarket chains (in this case Foodstuffs Auckland Limited, co-operatively owned and with its sister companies in Wellington and the South Island the dominant presence in the grocery market in New Zealand with a market share in the mid fifties per cent, and Progressive Enterprises Limited, a company owned by Foodland Associated Limited based in Perth, West Australia) that a poll challenge would be mounted. To generate the necessary signatures (15\% of eligible voters) is a task of considerable magnitude. While the legislation most probably envisaged local democracy, the irony is that challenges are likely to come from competitors. The even greater irony is that the Trusts (and thus the community) must pay all scrutineering and election costs. 
owned licensing trust shall co-exist alongside private enterprise operators open competition - or whether the trust shall have the exclusive right to licences defined in the Act. ${ }^{194}$ In a market orientated world that choice is unusual, if not unique.

This study seeks to analyse the circumstances surrounding the poll and to clarify why the community voted to protect the Trusts from further competition. If prices are higher because of this, and this is the general perception, it may be argued that the community accepts or has imposed a subsidy or tax on itself. The reasons it might do this are important in the context of the wider study of which this is a part. This wider study seeks to ascertain what purpose community ownership of trading enterprises may serve, particularly if private ownership can provide those services equally well or better. In West Auckland the community, on the face of it, voted that not only were community enterprises a good option, they sought to protect them.

To discover, explain and validate, this case study draws upon open-ended semi-structured interviews with the Trusts and supermarket representatives ${ }^{195}$, newspaper archives, annual accounts and reports, letters to the editors, correspondence files and market and other research commissioned by the supermarkets and the trusts. The methodology framework and justification is detailed in chapter 4 .

What follows is a description of West Auckland, the Licensing Trusts located there, and the circumstances surrounding the vigorously contested polls. Why the community voted to restrict competition and the perceived benefits and

\footnotetext{
194 Until a competition proposal poll is carried the trust has the exclusive rights to hold on-licences for hotels and taverns, and off-licences other than for clubs and vineyards. Thus, this precludes supermarkets from selling beer and wine in the remaining six trust (now 4 as at August 2005) areas defined in the Sale of Liquor Act.

195 Interviews were with the Presidents of the Portage and Waitakere Licensing Trusts, the Managing Director of Foodstuffs Auckland Limited, the General Manager and Marketing Manager of West Auckland Trust Services Limited, and the Marketing Manager of Progressive Enterprises Limited. These interviews were recorded.
} 
disadvantages are analysed along-with the lessons they may provide for other communities and for public policy in New Zealand.

\section{THE WESTIE SPIRIT}

The degree to which there are strong bonds of community is a significant factor in influencing whether community ownership is a viable option. Without a strong sense of community any defence of its income generating assets must logically be more difficult. It is reasonable to assume that a community is more likely to defend what it values and (emotionally) owns.

'Westies are different and proud of it' was a theme of the post-campaign focus groups and reinforced by the General Manager of the Trusts, himself a West Aucklander. What is different may be indefinable and part of folklore but there is little doubt that West Aucklanders take some satisfaction in being recognised as discerningly different from the rest of Auckland. ${ }^{196}$

The Licensing Trusts' publicity booklet ${ }^{197}$ records that the two Trusts cover an area of 246sq $\mathrm{kms}$ and contain a population of 230,000. The Waitakere Trust area borders Hobsonville in the north, Waiatarua in the south, Glendene and Te Atatu in the east and the Tasman sea in the west. Portage has a common boundary with Waitakere in the east, and includes Owairaka and Blockhouse Bay with the Waitemata and Manakau harbours providing the northern and southern boundaries.

These geographic and demographic descriptions of West Auckland give minimal insight into the community spirit and uniqueness that was described

\footnotetext{
196 Waitakere City is the key local authority serving the area with a population of 168,750 . By comparison with neighbouring Auckland City and New Zealand, West Aucklanders are younger $24.7 \%$ under 15 compared to Auckland with $19.7 \%$ and NZ 22.7\%), with less post-school qualifications ( $28.9 \%$, Au $41.2 \%$, NZ 32.2\%), have more Pacific Island people and less Asians than Auckland but more than NZ (Pacific Islanders 14.5\%, Au 13.7\%, NZ 6.5\%; Asians 11.0\%, Au 18.7\%, NZ 6.6\%), and have a higher median income than New Zealand but less than Auckland $(\$ 20,800$, Au $\$ 22,300$, NZ \$18,500). Source: Department of Statistics.

${ }^{197}$ Licensing Trusts- Life Blood of the West Auckland Community.
} 
during the interviews and evident in the post-campaign focus groups. Bob Harvey's ${ }^{198}$ publication 'Westies', a profile of 60 characters and icons, presents it passionately: 'Once a Westie, always a Westie...there's something special about people who have ever lived in West Auckland. It's as if they have been imbued with a spirit of freedom and independence by the west's awesome landscape, its commanding hills, rain forest and wild beaches. From Te Atatu to Titirangi, from Piba to Helensville, the west is full of extraordinary characters: pioneers, grafters, artists and visionaries. 199

The General Manager of the Trusts told a story. He was placing campaign signs one day when a beat-up old car pulled up alongside. A 20 year old 'bigger than me young guy' challenged him about the poll. His immediate assumption, reasonably justified by the greater percentage of young people voting against the advocacy in his campaign signs and the vigorous, contentious and polarising nature of the poll debate to date, was that what was likely to follow was a condemnation of his efforts. But then the challenger proceeded to list supportively everything the Trust had done for Massey High School, his alma mater. He wished to make sure he sent his voting papers in on time and had been actively encouraging his friends to vote for the Trust.

\section{THE HISTORY AND PERFORMANCE OF THE TRUSTS}

Both the Portage and Waitakere Trusts were gazetted in 1972 and the first elections held that year. Portage began trading in 1973 and Waitakere followed the next year. Between the two they now operate 40 business units with combined operating revenue in 2003 of $\$ 97.4$ million.

The supermarket companies gave a good deal of emphasis during the campaign to the performance of the Trusts. They commissioned an in-depth review by Horwath Porter Wigglesworth Limited, Chartered Accountants and

\footnotetext{
198 Currently Mayor of Waitakere City and a character of quite some notoriety.

199 The review summary on Bob Harvey's book, Westies, on web-site www.exisle.co.nz/Westies.
} 
Business Advisors. Press releases and advertising followed. One press release under the pen of the two supermarket chief executives stated:

The review...is highly critical of the trusts' financial performance and financial information disclosures.

Horwath's review was limited to Waitakere's audited financial statements for the years 1999 to 2001, extracts from that Trust's 2002 accounts and various promotional booklets and press releases. While Horwath were critical of the Trusts for not releasing the 2002 accounts and 'a philosophy of disclosing as little as possible' it is stretching the report to say they were critical of performance, in large part because the actual performance of the Trusts was not poor, and because, by their own admission, they maintained they did not have sufficient information to arrive at that conclusion.

It is doubtful that the ensuing exchange of allegations and denials had any effect on the poll outcome ${ }^{200}$ but the performance issue had the potential to be influential and is at the heart of the privatisation (private enterprise versus public) efficiency debate.

Appendix 1 records an analysis of both Trusts' audited accounts for the five years ended 31 March 2003. Return on equity over the five years for both Trusts averages a little over $8 \%$. By way of comparison Lion Breweries Limited averaged $7.2 \%$ and DB Breweries Limited 17.8\%. ${ }^{201}$ Profit had reduced particularly in the 2003 year as poll costs came to bear. ${ }^{202}$ Balance Sheets are strong with no debt (in 2003) and high equity ratios. In summary, the 'Trusts' financial performance compares satisfactorily, a position

\footnotetext{
200 This is supported by both pre and post-campaign research that strongly indicated voters decided which way they would vote at an early stage of the challenge, and thus swinging voters were minimal.

201 The DB result is inflated by the one off sale of Corbans. If this is adjusted to make the comparison fairer, DB's return on equity becomes $13.4 \%$.

202 These totalled $\$ 1.338$ million and net of tax would have a one year ROE impact for Waitakere of $2.8 \%$, and for Portage, $4.5 \%$.
} 
reinforced by the Controller \& Auditor-General's September 2003 report on Licensing Trusts. ${ }^{203}$

Not included in the Trusts' accounts are the profits from gaming generated on their premises. These are recorded in a separate trust, the Community Grants Foundation ${ }^{204}$, and are available to be distributed to the Portage and Waitakere communities.

Appendix 1 records that over the 5 year period, the Trusts' dividends back to the community totalled $\$ 25.5$ million. Much emphasis was given by the supermarkets to where these came from. The majority of donations were generated from gaming machines in the Trusts' premises and the supermarkets tried to press their case on the assertion that these would be available to the community irrespective of whether the Trusts were in existence or not, and whether full or restricted competition applied. ${ }^{205}$ The post-campaign focus groups and the poll result indicate that the subtlety of this argument had little impact on the voters. The policies adopted by the Trusts in distributing gaming profits and managing gaming had wide-spread support.

\section{HISTORY OF THE POLLS}

The competition poll legislation contained in sections 214-216 of the Sale of Liquor Act 1989 has frequently polarised those associated with it. Licensing Trusts view it as unfair and heavily weighted against them. The supermarkets and those advocating open competition believe it is an aberration in a market society.

\footnotetext{
203 Local Government: Results of the 2001-02 Audits, Office of the Controller \& Auditor-General (September, 2003). Page 87 records: 'Both Portage and Waitakere produce a return on equity of approximately $7 \%$ which is consistent with the industry average. They also have minimal term debt and adequate current ratios.'

${ }^{204}$ Now (2005) renamed the Trusts Charitable Foundation Incorporated.

205 This argument is based on the premise gaming profits have to be returned to the community. Thus the supermarkets argued they should not be treated per se as Trust donations.
} 
The Laking Committee that reviewed the sale of liquor that led to the major (and significantly liberal) changes of the Sale of Liquor Act 1989, recommended that the 13 Licensing Trusts which had preferential rights ${ }^{206}$ should lose them and the areas should be opened up to full competition. The Parliamentary Committee, however, after hearing submissions, decided on the half-way house legislation that now applies.

The Trusts argue that this legislation encourages the supermarkets with their considerable resources to keep on trying until a poll is passed. Once a poll is completed and if the status quo is voted, no further challenge can occur for 3 years. If a poll is carried, it is absolute. The Trusts cannot seek a reversal in 3 years time. The Trusts also argue that the requirement for them to pay all election costs is unfair when competitors are seeking a benefit. ${ }^{207}$

The opponents to this legislation argue that a Trust should be able to exist on equal footing with competitors; and support the New Zealand Herald editorials' assertion that a privileged position and lack of competition lead inexorably to inefficiency, waste and abuse.

13 polls have been held (see appendix 2). 7 have been carried and 6 have maintained the status quo. Notably, the last 4 in areas as diverse as Mataura, Ashburton and metropolitan Auckland have all supported the Trusts. ${ }^{208}{ }^{209}$

\footnotetext{
206 Trusts enjoyed the rights to all on and off licences in their area other than to clubs. In effect, all bottle-stores, taverns, bars and hotels were to be owned and operated by the Trusts. They were not, however, allowed to trade outside their area.

207 Even if a competitor was required to pay these costs, there could be ways around it by forming a (nominal) community group to front the challenge as occurred in Masterton in 1992. Any legislative change to the present Act would need to have an ability to look behind the challenge at its funding.

2084 of the poll were in the greater Wellington area (Porirua, Johnsonville, Terawhiti and Wellington South). These Trusts participated in a sizable business failure and the considerable community disenchantment with their performance would have influenced the polls' outcome.

209 Two further polls in Geraldine and Ashburton were held in November 2004 (after the study was completed). Both reversed the trend of the previous 4 polls by opening up the two trust areas for full competition. The Ashburton poll was narrowly carried (51.1\%), Geraldine overwhelmingly so.
} 


\section{WEST AUCKLAND: THE ISSUES AND INFLUENCES}

Why did the community vote as they did? While the answers are likely to be as varied as the individual voters, discernible themes arose from the interviews, letters to the editor, newspaper articles and the post-campaign focus groups. ${ }^{210}$ These themes can be grouped under the following headings:

- Pro or anti local ownership

- Pro or anti open competition

- Anti (growth in) alcohol

- Anti gaming

- 'Our profits' - Profit retention in the community

- If lost - lost forever

- Better campaign.

PRO OR ANTI LOCAL OWNERSHIP

Apart from those who held the more generic beliefs of anti-capitalism, pro private enterprise or pro or anti-local ownership, two factors in this group were seen to influence the poll. The distinctly West Auckland - 'Westie' spirit appeared to take exception to the supermarkets' advertising that their area was the only one in the North Island where beer and wine could not be bought in their stores. Advertising 'why should they be different' ran contrary to the presiding belief they were different.

The second influence flows from this. The poll forced people to make up their mind whether they supported local ownership. Thus, as the focus groups identified, a greater sense of ownership than before was created. As two

\footnotetext{
210 These latter were commissioned by the Trusts and carried out by UMR Research Limited. 6 were completed, 3 in the Portage area and 3 in Waitakere. 4 of the groups comprised residents who voted for the Trusts and 2 who voted against, a mix reasonably similar to the poll outcome (58/42).
} 
participants stated: 'By voting for it, that's what we've been saying. It's our Trust. It belongs to us. It's part of our community.'

The 'big business' tag given to the supermarkets was an associated factor that influenced a number of voters. A perception of arrogance ${ }^{211}$ reflected in Foodstuffs and Progressive's comments, advertising and money spent, gave more emphasis to the Trusts' advertising themes that the supermarkets were primarily interested in their own greed. The Australian ownership of Progressive reinforced to some that profits would not be spent locally, and would go overseas.

\section{PRO OR ANTI OPEN COMPETITION}

The supermarkets campaigned predominantly on themes of freedom of choice, lower prices and convenience of access to alcohol. The counter arguments were the number of liquor outlets already existing and the minimal differences in the prices offered by the Trusts.

\section{THE ANTI ALCOHOL INFLUENCE}

In any issues surrounding alcohol, there are a group of citizens steadfastly opposed to any liberalising of laws and access. This group of people while not particularly strident or influential in New Zealand at the present time ${ }^{212}$ are more likely to oppose the open competition advocacy of the supermarkets.

\section{ANTI GAMING}

In the last five years, poker-machine gambling has been allowed to double in

\footnotetext{
211 This was highlighted in the post-campaign research along-with a view that the supermarkets' advertising was aggressive. A review of all advertising suggests that for both sides it was forthright.

212 A factor here is the reduction in alcohol consumed per head of population that has occurred in recent times in New Zealand - in the order of 20-25\%. Refer alcohol consumption data of the World Health Organisation and Statistics NZ.
} 
New Zealand ${ }^{213}$. It is not surprising this has generated increasing concern to communities.

The Trusts emphasised during the campaign the responsible approach they had taken to the provision of gaming in their areas. They recorded that while there was one gaming machine per 171 people on average throughout New Zealand, in West Auckland it was 525. ${ }^{214}$ The focus groups that reviewed the poll saw this as positive and well exampled what Trusts had originally been legislated to be - to provide sensitive products like alcohol and gaming services with care, with the well-being of the community in mind. This, coupled with the Trusts' widely enjoyed distribution of profits policy, was seen to be influential.

\section{'OUR PROFITS'}

All interviewees and the post-campaign research emphasised the importance of the Trusts' donations programmes to the poll outcome. There were two aspects to this: firstly for some, the fear, or, for others, more mildly a concern, that the community would lose the benefits associated with the philanthropy; and secondly the positive enjoyment most of the community received from the gifts.

The Trusts gave a good deal of emphasis in their advertising to a promise that, if the status quo remained, they would be donating $\$ 80$ million back to the West Auckland community in the next ten years. That powerful message

\footnotetext{
213 The Department of Internal Affairs, who is responsible for the administration of gaming in New Zealand, record the startling statistics that poker machines, largely in bars and clubs but to a lesser extent also in casinos, had doubled over a five period to reach a high of 25221 in mid 2003. New legislation has now sought greater control, one aspect of which places greater authority at local (council) level. As at 31.12.2003, machine numbers had reduced to 22734, although there is some suggestion that the measurement basis may not be the same and may account for some of the difference.

214 A March 2005 publication by Gambling Watch (www.gamblingwatch.org.nz) listed Waitakere City as the area with the third lowest machines per head of population age 18 and over. Waitakere had 1 machine per 271 people age 18 and over compared to the New Zealand average of 1 machine per 118.
} 
was attempted to be negated by the supermarkets who argued that these donations came from gaming, not other Trust profits, ${ }^{215}$ and to be achieved would require the Trusts to install more gaming machines in their premises, thus conflicting with the control of gaming message; and if the area was opened up to more competitors then these gaming profits would still go back to the community but simply through other channels.

There is truth to the supermarkets' assertion that gaming profits wherever generated $^{216}$ must be distributed to the community but this was a mixed message for them. It ran counter to the proliferation of gaming machines concern, and was tempered by the realities of a New Zealand wide suspicion and concern over the often doubtful practices ${ }^{217}$ associated with the distribution of gaming profits. In addition, the Trust practices were enjoyed and respected.

It was the personal gifts to householders that the interviews and the focus groups highlighted as creating the most positive impression. In October/ November 2002 the Trusts donated a fire extinguisher to every home in West Auckland. So close to the poll this had the potential to be classed as a bribe and thus counter-beneficial. But it was not seen to be so by the great majority of the community because of the Trusts' previous history of such gifts. In 1998, the Waitakere Trust had paid for smoke alarms in every house in the area; in 1999 Portage had done the same; first aid kits had been provided by

\footnotetext{
215 As appendix 1 evidences, the majority of community donations did come from gaming profits $(96.3 \%)$ but it appeared that this was of quite limited importance to the voters. This may have been because the community was happy with the size and process of distribution; and that it made sense to retain non-gaming profits in the businesses for reinvestment.

216 The exception to this is clubs who may use the profits for their own internal purposes.

217 There is evidence (for example, in the recent review of gaming carried out by the Department of Internal Affairs) that some of the gaming trusts established to own and operate gaming machines in licensed premises and to distribute the profits for authorised purposes (predominantly charitable), have high expenses (related to personal gain) and thus distribute only the regulated minimum of $33 \%$ (or close thereto) of gaming income. There is evidence too, that some give more emphasis to donations to sporting clubs who purchase their liquor requirements from them. The West Auckland Trusts have consistently maintained a high percentage payout and cross-sectional distribution (for example, education and welfare).
} 
Waitakere in 1999 and car seats were available to every mother in West Auckland for a small administration fee to Plunket.

Notable also for their impact, but more controversial, were the major donations to schools. Education had always enjoyed support from the Trusts $^{218}$ and in February 2003, the month of voting, the Portage Trust announced a $\$ 1$ million donation to all schools in the Portage area. At the same time, the Principals were asked to support the Trust by sending a letter home to parents. Approximately $80 \%$ agreed to do so. The National Business Review took exception asserting (Issue of 14 February 2003):

West Auckland might be breaching the Education Act by colluding with licensing trusts to pressure parents over a vote for the future of monopoly control of liquor sales.

The community support donations of the Trusts were always likely to be an influential factor in the poll and there is ample evidence that is what they proved to be. The promise of $\$ 80$ million over 10years was significant and while the New Zealand Herald and the supermarkets may have doubted its authenticity, it was clear from the interviews with the Trust people they were serious and genuine. Notably also, in the two previous years the Trusts had averaged $\$ 8.4$ million per year.

\section{LOST FOREVER}

That a competition poll once carried cannot be reversed was the status quo, cautionary position that those who did not have strong views may have adopted. It was the fail-safe position - leave well alone. The Trusts certainly encouraged this view with advertising themes of the community assets and funding are at risk, and our funds will reduce by two thirds if they (the supermarkets) win the proposal.

${ }^{218}$ In the 3 years to March 2003, the Trusts had donated $\$ 4.960$ million to schools (Portage $\$ 3.283 \mathrm{~m}$ and Waitakere $\$ 1.677 \mathrm{~m})$. 


\section{BETTTER CAMPAIGN}

Both the focus groups and the supermarket executives acknowledged the Trusts ran a very good campaign. It was well thought out, mainly focused on the key issues and not allowed to stray to side shows, and largely in tune with the pace and culture of the community. Two influences here may have helped the professionalism and research disciplines the Trusts brought to bear. The Trustees were familiar with democratic election campaigns and this was definitely that, rather than a market research study and product advertising campaign with which the supermarkets would have been more knowledgeable. The second factor was the high stakes for the Trusts - if the poll was carried, major change immediately would occur. Business life as the Trusts were use to would cease. ${ }^{219}$

\section{SUMMATION}

81,701 people voted in the polls. 47,774 supported the status quo, in effect the Trust's position. 33,927 voted for open or more competition and the cessation of the Trusts' privileged position. With those numbers, it would be erroneous to give an impression that these polls were decided on one or even a limited number of issues. Some issues, like the community donations of the Trust and the convenience and better prices contentions of the supermarkets, had more influence on voters than others. But it is not possible, on the information available, to give weightings to all the complexities.

\footnotetext{
219 The author experienced the after effects of a competition poll being carried. In 1992, in Masterton, that Trust defended a challenge by Woolworths that saw the exclusive rights maintained by a vote of $54 \%$ to $46 \%$. However, after analysing all factors with perhaps the most important being the mood of the community and the opportunity to trade outside the area, the Trust decided not to defend the 1995 poll challenge which was then comfortably passed. Within weeks of the poll outcome six new (and substantial) competitors existed. Arguably, no amount of preparation could position any organisation for the competitive and trading environment that followed over the next nine months. Between the 1996 and 1997 financial years sales fell $14 \%$ and profit from $\$ 885,700$ to $\$ 7,700$.
}

Notably in the years since, the Trust has gone from strength to strength as reflected in the vignette in section 2.2.2. 
In the end (and after the intensity of the contest there was wide-spread pleasure that the end had arrived) 13,847 votes was the difference, a position the supermarkets said was close. Given that they expected to win it is difficult to see that comment as accurate. The reality was that the supermarkets needed $20 \%$ more votes than they received to effect change; or in another way $^{220}$, they were 16 percentage points short of the outcome they sought. From almost every view the polls' result was emphatic.

These polls are undoubtedly significantly confrontational. The community by majority vote decides the winner but in the process polarises itself. Further, it is a costly exercise diverting energy away from the positive creation of profits and consolidation of business enterprise. It will, almost certainly, continue every three years until the supermarkets win or voting for the status quo becomes so high that the supermarkets see little purpose in challenging. The obvious question arises: is there not a better way? Why can not the supermarkets representing legitimate private enterprise co-exist in the selling of beer and wine alongside the Trusts as happens elsewhere in New Zealand? While the framers of this legislation may have intended this confrontation in the 'red-hot' privatisation era of the late 1980s, it is fair now to consider its relevance in the context of the growth of the third sector (see chapter 3) and the realisation that a 'good' community will have a range of structures and choice.

\section{A FAIR CONCLUSION?}

The 2003 Trusts' accounts record they spent \$1.3million defending the poll. The supermarkets state they spent a similar amount. Assuming that \$2.5$\$ 3$ million was the total spent (and there is anecdotal information that suggests that the top end of that range is more correct, if not an under-estimate) what did the community gain or lose?

\footnotetext{
220 This assumes that half of the difference between the two of 13,847 votes would have needed to be reversed to effect the alternative outcome. Another way to view the result is that the supermarkets needed $\mathbf{4 0} \%$ more votes to equate to the Trust vote.
} 
The gains:

- A closer sense of community ownership of the Trusts. The polls forced people to decide. Like Eketahuna (see chapter 5) and Cohen's (1985: 104118) assertion of community, a decision had to be made as to what was valued most.

- More knowledge of the Trusts. To plead their cases the Trusts and the supermarkets informed the community, even if at times it was selective to advance their perceived strengths.

- Retention of community control over the number of gaming machines. The community legitimately had a concern over the proliferation of machines and their consequential problems of abuse (which local authorities have now moved throughout New Zealand to regulate), but there was clear evidence the Trusts had exercised restraint and moderation well before it became fashionable to do so.

- Retention of control over gaming profits. The community enjoys and supports the balanced processes of distribution the Trusts apply.

- Greater control over the number of liquor outlets. An open competitive environment for the sale of liquor inevitably creates opportunities for abuse particularly by the young.

- Profit distribution more likely to reflect the wider needs of the community rather than sporting. There is evidence to suggest that gaming distributions tend to be heavily weighted to sport. As the vignette in section 2.2.2 and the Trusts' lists of donations indicate, the Trusts are actively involved in education and community/welfare support. 
- Profits retained in the community. Supermarkets compete in a fiercely combative market and seek to maximise their profits for their owners who may not be resident in the community.

- Orderly management and growth of licensed premises and gaming. The trusts are able to plan in an orderly fashion with less disconcerting need to react to a multitude of competitors.

- The Trusts are better able to grow and consolidate their strength. Radical change will occur to the Trusts if the competition option is passed.

But any such gains must be offset against these losses:

- More competitive prices. Supermarkets operate at the lowest prices end of the market. Further, more bars will inevitably create downward pressure on prices.

- Wider choice of premises and greater variety. Removing the restrictions on access to liquor licenses will give rein to greater individual entrepreneurship and creativity.

- Convenience of buying wine and beer at supermarkets. Opinion polls consistently indicate the majority of people prefer this option being available to them.

- Ability to buy beer and wine more restricted. An open license environment will see the advent of more corner liquor stores. ${ }^{221}$

- The money spent contesting the polls. Was the considerable time and expense of the polls justified?

\footnotetext{
221 This and other statements in this list of gains and losses (for example, the proliferation and variety of licenses, supermarket prices) are not supported with evidential references because the writer believes them to be self-evident.
} 
A person may choose one or a combination of the above to support their point of view. It was clear voters were polarised and there were strong opinions both ways. The strength of the community support was very evident in the inaugural Friends of the Trust meeting where 300 residents, the Mayor of Waitakere City, and local Members of Parliament, both Labour and National, gave vocal support. ${ }^{222}$

The supermarkets too had taken their soundings and pursued the poll because many customers were asking why could they not purchase beer and wine in supermarkets. They did not expect to lose, although they said they knew it would be close.

So, was the outcome worth the cost?

It is difficult to escape the conclusion, after weighing all the evidence and reviewing the interview tapes, that this is an unfinished affair. The supermarkets have gone on record to say they will be back again in three years time. Simply, for them there is too much sales and profits at stake not to do so. If the poll was only about the issue of beer and wine in supermarkets, the strong view was formed during this research that by far the majority of voters would support that issue. Thus, the legislation captures issues far wider (as it was intended to do) but it must be questioned whether it is now, or ever was, good law. An argument to unhinge the beer and wine in supermarkets issue from the wider and more complex preferential or monopoly rights of community ownership appears to have considerable logic. There is a comparative precedent in the sale of liquor in clubs which occurs in the Trust districts. If this were to occur, the competition poll legislation could more genuinely still be available for the bulk of issues listed. If the community were dissatisfied with the services and performance of the Trusts, then they, not a competitor, could pursue a competition poll to force change.

\footnotetext{
222 That evening, MP David Cuncliffe is recorded as saying: 'This is the most powerful gathering of community groups he has ever seen.' The Friends of the Trust formed a 13 strong group and actively lobbied for support and wrote letters to the editor and media releases.
} 


\section{THE LESSONS}

Good legislation or not, competition polls under the Sale of Liquor Act have the potential to give insights as to whether community ownership is favourably received as a practical alternative to private enterprise, and why. The competition poll appears to emphatically evidence that it is, but is such a single judgement a fair summary of the poll result?

The poll result captures some complex issues. For some voters it may not so much have been a vote for community ownership as a vote against a globalised world over which they believe they have little influence. For others it may have been more a vote of concern over gaming, or alcohol sales to the young. For still others the major influence may have been retention of the gaming dividend to the community in the wide and even-handed process the Trusts have adopted. It is not possible to arrive at simple judgements because each voter's decision had the potential to be influenced by a range of factors.

But that qualification noted, there are conclusions that can fairly be reached. Table 1 lists these with a commentary for each. 
TABLE 1

\section{SUMMARY OF LESSONS}

\begin{tabular}{|c|c|}
\hline LESSON & COMMENTARY \\
\hline Community ownership is enjoyed. & $\begin{array}{l}\text { The polls result, and that of others in } \\
\text { Mataura and Ashburton, reinforces } \\
\text { that provided it performs well, and is } \\
\text { respected, communities support the } \\
\text { concept of a community enterprise. }\end{array}$ \\
\hline $\begin{array}{l}\text { Community enterprises can perform } \\
\text { efficiently and well. }\end{array}$ & $\begin{array}{l}\text { The results listed in Appendix 1, } \\
\text { evidence the West Auckland Trusts } \\
\text { performed at least adequately and } \\
\text { achieved results better than a number } \\
\text { of publicly listed companies. }\end{array}$ \\
\hline $\begin{array}{l}\text { The Trusts were perceived to } \\
\text { monitor and control sensitive } \\
\text { products well. }\end{array}$ & $\begin{array}{l}\text { The lesser incidence of gaming } \\
\text { machines in West Auckland was } \\
\text { commented on favourably by the } \\
\text { focus groups as was the lack of an } \\
\text { open market for liquor. }\end{array}$ \\
\hline $\begin{array}{l}\text { The Trusts were perceived to } \\
\text { distribute the community donations } \\
\text { dividend well. }\end{array}$ & $\begin{array}{l}\text { While a fear that it may be lost } \\
\text { influenced some voters, more } \\
\text { influential was the process and } \\
\text { breadth of the distribution. }\end{array}$ \\
\hline $\begin{array}{l}\text { Local ownership and control is now } \\
\text { more in favour. }\end{array}$ & $\begin{array}{l}\text { Recent writings (for example: Gates, } \\
\text { 1998; Shuman, 2000), and the growth } \\
\text { of the third sector, reinforced by the } \\
\text { polls' result, suggest that there is now } \\
\text { a more receptive climate for } \\
\text { alternative ownership structures to } \\
\text { complement private ownership. }\end{array}$ \\
\hline
\end{tabular}


TABLE 1

\section{SUMMARY OF LESSONS (cont)}

\begin{tabular}{|c|c|}
\hline $\begin{array}{l}\text { Community enterprises have the } \\
\text { potential to strengthen and enhance } \\
\text { the quality of life of a community } \\
\text { (for example, by the support of } \\
\text { community organisations and } \\
\text { events, and a balanced approach - } \\
\text { not profit maximisation - to the sale } \\
\text { of alcohol and gaming services). }\end{array}$ & $\begin{array}{l}\text { Beer and wine in supermarkets, and } \\
\text { open market competition in liquor } \\
\text { licences and gaming, were perceived } \\
\text { as more mundane issues, offering little } \\
\text { to deepen the community's quality of } \\
\text { life. }\end{array}$ \\
\hline $\begin{array}{l}\text { People are more important than } \\
\text { profits. }\end{array}$ & $\begin{array}{l}\text { In many ways this is almost a } \\
\text { meaningless statement but it continues } \\
\text { to have emotional appeal for a good } \\
\text { number of people concerned with } \\
\text { society's concentration on the } \\
\text { individual and materialism. These } \\
\text { themes and this statement were } \\
\text { evident during the poll in newspaper } \\
\text { articles, letters to the editor and in the } \\
\text { focus groups. }\end{array}$ \\
\hline $\begin{array}{l}\text { Beer and wine sales in supermarkets } \\
\text { are supported by the majority of } \\
\text { people. }\end{array}$ & \\
\hline $\begin{array}{l}\text { Community ownership monopolies } \\
\text { are unlikely to be stable } \\
\text { arrangements, because private } \\
\text { businesses face very strong } \\
\text { incentives to challenge them as often } \\
\text { as possible. }\end{array}$ & \\
\hline
\end{tabular}


It is almost stating the obvious to caution that one of the key messages of the vigorously contested polls is that these lessons would not be universally agreed upon.

\section{CONCLUSION}

For all these reasons most of the country did away with licensing trusts long ago. Trust monopolies survive only in Ashburton, Geraldine, Soutbland and, alone in the North Island, West Auckland. They are an anachronism - and so are the licensing polls. By what right should a majority be able to prevent anybody trading in a lawful product? The days of regulating the number of competitors in any trade are well gone. ${ }^{223}$

Notwithstanding the New Zealand Herald's and other major newspapers' views, ${ }^{224}$ the voters in the competition polls in West Auckland in 2003 by a significant majority sought to preserve and protect their community owned Licensing Trusts. By these results the majority of voters are asserting that community enterprises do serve a purpose and continue to be enjoyed and respected in $21^{\text {st }}$ century New Zealand.

\footnotetext{
223 The quote is from the New Zealand Herald editorial of 28 February 2003. The accuracy of a number of statements therein is questionable; for example, that licensing trusts have been abandoned by their communities, and that the majority do not regularly inflict their view on the minority - such is the nature of politics and law. But the editorial is a powerful (and influential) reflection of the dominant beliefs in New Zealand society, that private enterprise will provide better.

224 The National Business Review and the Evening Post have both featured strong editorial views that Licensing Trusts are anachronistic (for example, Evening Post editorial of 27 March 1999).
} 
APPENDIX 1

ANALYSIS OF PORTAGE AND WAITAKERE ACCOUNTS

WAITAKERE LICENSING TRUST

\begin{tabular}{|c|r|r|r|r|r|}
\hline YEAR & $\begin{array}{r}\text { SALES } \\
\mathbf{\$ m}\end{array}$ & $\begin{array}{r}\text { PROFIT } \\
\mathbf{\$ m}\end{array}$ & $\begin{array}{r}\text { ROE } \\
\mathbf{\%}\end{array}$ & $\begin{array}{r}\text { ROA } \\
\mathbf{\%}\end{array}$ & $\begin{array}{r}\text { EQUITY } \\
\mathbf{\%}\end{array}$ \\
\hline 1999 & 38.7 & 1.438 & 12.1 & 9.6 & 80.3 \\
\hline 2000 & 45.5 & 1.478 & 11.1 & 8.6 & 76.2 \\
\hline 2001 & 51.5 & 1.169 & 8.0 & 6.3 & 79.7 \\
\hline 2002 & 53.9 & 1.175 & 7.5 & 6.0 & 79.2 \\
\hline 2003 & 58.4 & 0.414 & 2.6 & 2.1 & 82.7 \\
\hline MEAN & & & 8.3 & 6.5 & 79.6 \\
\hline
\end{tabular}

PORTAGE LICENSING TRUST

\begin{tabular}{|c|r|r|r|r|r|}
\hline YEAR & $\begin{array}{r}\text { SALES } \\
\mathbf{\$ m}\end{array}$ & $\begin{array}{r}\text { PROFIT } \\
\mathbf{\$ m}\end{array}$ & $\begin{array}{r}\text { ROE } \\
\mathbf{\%}\end{array}$ & $\begin{array}{r}\text { ROA } \\
\mathbf{\%}\end{array}$ & $\begin{array}{r}\text { EQUITY } \\
\mathbf{\%}\end{array}$ \\
\hline 1999 & 35.9 & 1.035 & 14.5 & 9.8 & 72.8 \\
\hline 2000 & 38.1 & 0.941 & 11.7 & 8.6 & 74.4 \\
\hline 2001 & 38.7 & 0.648 & 7.2 & 5.4 & 75.0 \\
\hline 2002 & 39.4 & 0.587 & 6.2 & 4.7 & 78.7 \\
\hline 2003 & 39.0 & 0.228 & 2.3 & 1.8 & 77.2 \\
\hline MEAN & & & 8.4 & 6.1 & 75.6 \\
\hline
\end{tabular}

Explanatory Notes:

All data is compiled from the audited annual accounts of the Trusts. Profit is after tax. ROE (return on equity) is calculated by dividing profit by equity. ROA (return on total assets) is calculated by dividing profit by total assets. The equity per cent represents the ownership stake and is arrived at by dividing equity by total assets. It should be noted that gaming profits 
generated on Trust premises are NOT included in the above results even though they are distributed to the community. Because the Trusts choose to operate this function through another enterprise structure, the gaming profits are not consolidated into the Trusts' accounts. Thus, the Trusts' accounts were taken as the basis for the above schedules.

Were gaming profits included (as arguably they should be to reflect the real return from Trust assets employed), returns on equity would increase significantly to around $25 \%$.

\section{SELECTION OF PUBLICLY LISTED COMPANIES KEY PERFORMANCE INDICATORS}

5 YEARS 1999-2003

\begin{tabular}{|l|r|r|}
\hline COMPANY & $\begin{array}{r}\text { RETURN ON } \\
\text { EQUITY \% }\end{array}$ & $\begin{array}{r}\text { EQUITY RATIO } \\
\text { \% }\end{array}$ \\
\hline CDL Hotels $^{225}$ & 4.4 & 71.1 \\
\hline Lion Nathan & 7.2 & 53.2 \\
\hline DB Breweries & 17.8 & 66.5 \\
\hline Restaurant Brands & 35.5 & 36.6 \\
\hline Tourism Holdings & & 55.6 \\
\hline
\end{tabular}

Note: The selection of the above companies was based on their involvement in trading fields broadly similar to the Trusts. In all five cases, however, there are significant points of difference: for example, size, sales mix, and manufacturing. All information gathered is as recorded in the annual reports of the companies. There are some minor differences in calculation methods which have minimal impact for the comparative purposes of this table.

\footnotetext{
225 These results are for three years only: 2001 to 2003.

226 These results are for the five years ending 2004.
} 


\section{COMMUNITY DONATIONS}

\section{WAITAKERE LICENSING TRUST}

\begin{tabular}{|c|r|r|r|}
\hline YEAR & $\begin{array}{r}\text { Ex NON } \\
\text { GAMING } \\
\mathbf{\$ m}\end{array}$ & Ex GAMING & TOTAL \\
\hline 1999 & 0.205 & 1.345 & $\mathbf{\$ m}$ \\
\hline 2000 & 0.037 & 2.242 & 1.550 \\
\hline 2001 & 0.015 & 1.233 & 1.248 \\
\hline 2002 & 0.245 & 2.685 & 2.930 \\
\hline 2003 & 0.171 & 3.945 & 4.116 \\
\hline TOTAL & 0.673 & 11.450 & 12.123 \\
\hline MEAN & 0.135 & 2.290 & 2.425 \\
\hline
\end{tabular}

PORTAGE LICENSING TRUST

\begin{tabular}{|c|r|r|r|}
\hline YEAR & $\begin{array}{r}\text { Ex NON } \\
\text { GAMING } \\
\mathbf{\$ m}\end{array}$ & $\begin{array}{r}\text { Ex GAMING } \\
\mathbf{\$ m}\end{array}$ & $\mathbf{\$ m}$ \\
\hline 1999 & & 0.462 & 0.462 \\
\hline 2000 & 0.013 & 1.069 & 1.082 \\
\hline 2001 & 0.003 & 1.976 & 1.979 \\
\hline 2002 & 0.076 & 2.777 & 2.853 \\
\hline 2003 & 0.181 & 6.794 & 6.975 \\
\hline TOTAL & 0.273 & 13.078 & 13.351 \\
\hline MEAN & 0.055 & 2.615 & 2.670 \\
\hline
\end{tabular}

Explanatory Notes:

The figures were compiled from audited annual accounts and annual reports to the public. 
APPENDIX 2

RESULTS OF COMPETITION POLLS

UNDER SECTION 215 SALE OF LIQUOR ACT 1989

\begin{tabular}{|l|c|r|r|r|r|}
\hline TRUST & YEAR & $\begin{array}{r}\text { VOTES } \\
\text { FOR }\end{array}$ & $\begin{array}{r}\text { VOTES } \\
\text { AGAINST }\end{array}$ & $\begin{array}{r}\text { \% } \\
\text { FOR }\end{array}$ & $\begin{array}{r}\text { \% } \\
\text { AGAINST }\end{array}$ \\
\hline Masterton & 1992 & 5057 & 5900 & 46 & 54 \\
\hline Clutha & 1992 & 4131 & 2273 & 65 & 35 \\
\hline Oamaru & 1992 & 5568 & 4775 & 54 & 46 \\
\hline Ashburton & 1993 & 5862 & 5954 & 49 & 51 \\
\hline Masterton & 1995 & 6446 & 3113 & 67 & 33 \\
\hline Johnsonville & 1997 & 5028 & 2850 & 64 & 36 \\
\hline Porirua & 1997 & 12306 & 3034 & 80 & 20 \\
\hline Terawhiti & 1997 & 7438 & 2390 & 76 & 24 \\
\hline $\begin{array}{l}\text { Wellington } \\
\text { South }\end{array}$ & 1997 & 3384 & 2310 & 59 & 41 \\
\hline Ashburton & 1998 & 4919 & 6283 & 44 & 56 \\
\hline Mataura & 2002 & 4086 & 5227 & 44 & 56 \\
\hline Portage & 2003 & 14994 & 21853 & 42 & 58 \\
\hline Waitakere & 2003 & 18933 & 25921 & 42 & 58 \\
\hline
\end{tabular}

Explanatory Note:

If voters wish to achieve open competition in the Trust area, they must vote for the competition option. It they wish to retain the status quo, they must vote against.

Post script:

In November 2004 two polls were held in Geraldine and Ashburton. Both opened the areas up to full competition. 
Chapter 7

\title{
TSB BANK \\ AND \\ TSB COMMUNITY TRUST
}

A

\author{
CASE STUDY \\ OF \\ COMMUNITY ENTERPRISE \\ AND \\ COMMUNITY SUPPORT
}

To many in New Zealand, the TSB Bank is an icon. During the rampant years of privatisation it went its own way, against the trends of the other banks, and went from strength to strength. There is much that is admirable in what follows. And yet if the reader comes away not sure if its essence has been captured, then they would share that with the writer.

In chapter 4 it was asserted that all communities and organisations have a culture. The TSB Bank pursues business efficiency. That dominates and helps to explain the laudable financial results. If the writer had to answer the question whether it is more than a strong financial institution and a giver of money, he would stumble in his explanations. Some would argue that the issue is fanciful and what does it matter if the TSB is an icon or not. Yet great organisations often transcend description. They often have characteristics that attract and endure. Whether the Bank and the Trust have those factors is questionable and in any event, that is not the purpose of the study. Yet the writer was drawn to the icon status, if it is true. It can not solely be business results, for other banks and other organisations that would never be considered icons achieve as well or better. Thus, what other factors are there to the TSB?

It is left to the reader to decide. 
This study began with an unrecorded 'pilot' interview with the Managing Director in December 2002. But the study did not begin in earnest until February 2004 when the search for the written word and initial interviews in March 2004 were completed. The study was again then left to complete other research (chapter 2). One year later the balance of the interviews and the literature search were completed. In May 2005 supervisory comment was received and in June the draft study was sent to all interviewed for validation (four replied).

It was mid 1986 and great change was occurring in the New Zealand economy. The Lange led Labour Government elected in 1984 had already revolutionised economic management. Roger Douglas, the Minister of Finance and the architect of much of the remodelling, had made clear that excessive public debt ${ }^{227}$ was significantly crippling and shackling the country. Privatisation and state asset sales were firmly on the agenda. ${ }^{228}$ The State Owned Enterprises Act 1986 was to provide the legal framework for the Government to remove themselves from an extensive trading involvement in assets that were collectively performing poorly. ${ }^{229}$

The country's 12 trustee savings banks would not escape the reform process. In 1984 Roger Douglas had given them notice that they would have to exist in an open, more competitive, less regulated environment, and without the Government guarantee that had been part of their traditional financial framework. ${ }^{230}$ Some banks were not in a strong financial position and could not look forward to this new and very different future with confidence. Amalgamation to gain collective volume, skills and strength offered one way.

\footnotetext{
227 Refer Institute of Policy Studies (1988:3-6), speech by Hon. Roger Douglas.

228 Refer Institute of Policy Studies (1988:7-12), speech by Hon. Richard Prebble.

229 An often quoted (Spicer, et al, 1996:9; Jennings and Cameron, 1987, Douglas and Callen, 1987:234) performance summary of the effectiveness of state trading assets was that as at 1985/86, $\$ 20$ billion was invested in the Airways system, Post Office, Lands and Survey Department, Forest Service, State Coal Mines and the Electricity Division of the Ministry of Energy, and yet returned no net after tax profit to its owners, the New Zealand Government.

${ }^{230}$ Graham Scott's (2002:4-7) fine analysis describes the circumstances and the events, as do a number of newspaper articles at that time; for example The Taranaki Daily News of 26, 27, 28 June and 2 July 1986.
} 
One bank, Taranaki, opted to go it alone and retain their community roots. Today it is rated the best bank in New Zealand. ${ }^{231}$ Its volume of business has increased ten-fold since 1986. On most points of measurement it rates as an outstanding success. By comparison, the 11 other banks no longer exist. ${ }^{232}$ Throughout its 155 year existence, and never more so than during the last 20 years, the TSB Bank has remained fiercely protective of its independent-status and its Taranaki roots. Its annual dividend of approximately $\$ 5$ million supports many Taranaki events and organisations. On the weight of these successes and its longevity it appears to offer a good deal of worthwhile lessons as a community enterprise that has stood the test of time.

This case study canvasses and tests this premise. A short history with an up to date profile is presented along-with a review of performance and comparison to other banks. Mission and Vision highlights how the Bank and the Trust see their roles. Ownership and the community and accountability issues are discussed particularly in relationship to appointment of trustees and governance. Finally, the study chronicles the distribution of community support and dividend policies and examples a counterfactual exploration of what if the Bank had not chosen to go it alone in 1986.

The information herein is derived from a number of sources. A key source was recorded interviews with people who have had a major influence in the events of the past twenty years, and in the Managing Director's case, an involvement of over 40 years. ${ }^{233}$ Newspaper archives, annual reports and

231 The TSB Bank has been rated 'best bank' for the last five consecutive years by the independent survey of the University of Auckland on customer satisfaction and loyalty. TSB Bank competes in the residential banking section only, where its ratings are far above any other bank (mid 90s percent compared to the next highest bank of mid 70s). Refer web-site www.business.auckland.ac.nz.

232 It may be argued that the Auckland Savings Bank continues to exist as the (successful) ASB. However, that bank is now wholly owned by the Commonwealth Bank of Australia. Thus, the intent of this statement is true - of the 12 community banks in existence in 1986, only the TSB remains.

233 The people interviewed were: Kevin Rimmington (twice), Managing Director of the TSB Bank; Paul Butterworth, Chairman of the TSB Community Trust; Jen Blyde, Manager of the TSB Community Trust; Hon. Harry Duynhoven, MP for New Plymouth; David Lean, long-time Director of the TSB Bank and Mayor of New Plymouth from 1980-92; Kinsley Sampson, for 21 years the CEO/GM of 
annual accounts, and a variety of other reference works, as listed herein, complete the resources.

\section{A SHORT HISTORY AND UP TO DATE PROFILE}

There is a lovely story that will no doubt gain in romantic appeal as the years roll by: how Waitera te Karei travelled south from Mokau, a distance of $90 \mathrm{kms}$, to make the first deposit of 34 pounds, in September 1850, in the newly founded New Plymouth Savings Bank (TSB Bank, undated publication). As Graham Scott (2002:4) records 'the savings bank model in New Zealand was based on the Scottish system of many purely local banks started by local individuals. Capital was raised locally and management was entrusted to those who were known to and trusted by local constituents, claiming as one of their principal qualifications a close knowledge of local requirements and characteristics. ${ }^{234}$

It was not until 1921 that the second branch was opened in the nearby suburb of Fitzroy. Today there are 15 branches that are maintained to a high standard. The Bank takes pride in their branches and as a policy seeks to extend and enhance them - a strategy that is the opposite of industry trends $^{235}$, but a smart one appreciated and supported by their customers, and entirely consistent with its localised status. TSB Realty, TSB Holiday Shoppe and TSB Foreign Exchange add to the range of services offered by the Bank. In recent years Home Loan Lounges have been opened in Christchurch and Auckland.

In 1964 the name of the Bank changed to the Taranaki Savings Bank representing a reaching out 'to the rest of the province' (TSB Bank, undated

\footnotetext{
New Plymouth City/District Council; and Willie Still, District Councillor from 1982-86 and prominent businessman. There were also discussions with the Mayor, Peter Tennent and former long time Chief Accountant of the New Plymouth City/District Council, Kevin McEvoy.

${ }^{234}$ Scott's reference is Moore and Barton (1935).

235 This is not to suggest that other banks do not attractively adorn their branches but that the industry trends have been towards volume, amalgamation and closure of many branches particularly in smaller population centres.
} 
document). The final name change occurred in 1988 when separation of ownership and operations was created by the Government's restructuring programme. The TSB Community Trust was formed as the sole owner of the TSB Bank with 20 million 50cents shares (\$10 million capital). That capital has grown with profit retention to just on $\$ 160$ million as at September 2004.

It took until 1981 for depositors' funds to reach \$100million and only a further 5 years for that to double. Today they have topped \$2billion.

\section{REVIEW OF PERFORMANCE}

Table 1 presents a summary of key financial indicators ${ }^{236}$ for the past 10 years:

TABLE 1

\begin{tabular}{|c|r|r|r|r|r|}
\hline YEAR & $\begin{array}{r}\text { TOTAL } \\
\text { INCOME }\end{array}$ & $\begin{array}{r}\text { TAX } \\
\text { PAID } \\
\text { PROFIT } \\
\mathbf{\$ m}\end{array}$ & $\begin{array}{r}\text { TOTAL } \\
\text { EQUITY }\end{array}$ & $\begin{array}{r}\text { RETURN } \\
\text { ON } \\
\text { EQUITY } \\
\mathbf{9}\end{array}$ & $\begin{array}{r}\text { RETURN } \\
\text { ON } \\
\text { ASSETS } \\
\mathbf{\%}\end{array}$ \\
\hline 2004 & 137.4 & 23.1 & 147.2 & 16.7 & 1.19 \\
\hline 2003 & 126.9 & 21.4 & 129.2 & 17.7 & 1.24 \\
\hline 2002 & 111.8 & 18.4 & 112.6 & 17.5 & 1.21 \\
\hline 2001 & 106.4 & 16.6 & 98.3 & 18.2 & 1.26 \\
\hline 2000 & 80.5 & 12.8 & 85.1 & 16.1 & 1.11 \\
\hline 1999 & 86.2 & 11.3 & 74.2 & 16.2 & 1.14 \\
\hline 1998 & 78.4 & 9.4 & 64.6 & 15.5 & 1.16 \\
\hline 1997 & 72.0 & 7.2 & 56.5 & 13.5 & 1.07 \\
\hline 1996 & 62.6 & 6.9 & 50.5 & 14.5 & 1.18 \\
\hline
\end{tabular}

236 All information has been taken from the annual financial statements of the TSB Bank Limited. Return on equity equates to operating surplus after tax as a percentage of average shareholder's funds, and return on assets is the return on total average assets both as shown in the statements. 


\begin{tabular}{|l|l|l|l|l|l|}
\hline 1995 & 51.4 & 5.7 & 44.7 & 13.5 & 1.09 \\
\hline
\end{tabular}

These results are admirable. Any Chief Executive, Board of Directors, or shareholder would express pleasure at these results, as many people in Taranaki and elsewhere do so ${ }^{237}$. To grow income by $167 \%$, increase profit four-fold, add $\$ 100$ million to equity and achieve ROE percentages consistently in the mid to high teens over a better than ten year period, are results that few commercial organisations regularly achieve.

Pressures and problems that had to be overcome were the smallness of the home market, Taranaki, with a population of $103,000^{238}$ (answer: transport their products and services elsewhere throughout New Zealand ${ }^{239}$ ), a very competitive banking market intent on volume and size ${ }^{240}$ (answer: emphasis their niche and seek to be excellent in what they $\mathrm{do}^{241}$; technology leadership has also contributed significantly), equity/capital risks because the sole shareholder, the TSB Community Trust, has no ready access to capital should the bank require additional equity to meet either urgent or growth needs ${ }^{242}$ (answer: maintain high capital adequacy ratios ${ }^{243}$ and greater retention of profits to instil confidence), and an uncommon ownership structure (answer:

\footnotetext{
237 As all those who were interviewed concerning the performance of the Bank did. The praise was also reflected in many other discussions the writer was involved in concerning The TSB Bank.

${ }^{238}$ Refer the Department of Statistics. Population fell 3.5\% between the last two census, 2001 and 1996.

239 As one interviewee noted, his son who lived in Tauranga had his home mortgage with the TSB Bank. The 2003 annual report noted that although the Auckland Home Loan Lounge had been opened for 6 months, 'it has already approved over\$69million in loans' (:8)

240 As reflected in the bank mergers and overseas ownership of all banks in New Zealand other than the TSB Bank and the recent entrant, kiwibank.

${ }^{241}$ Refer note 231.

242 It may be argued that from its resources it has no ability to provide capital of any significance. That would be true in the traditional sense of raising equity capital but new examples of community generated capital are arising. Eketahuna provides a wonderful, if small, case example of how a community can raise capital; in their circumstances, to provide a supermarket and service station. Shuman (2000) discusses options and Shore (2001) provides examples.

243 The Bank's conditions of registration require certain formulas to be met. (See, for example, their annual reports and web-site www.tsb.co.nz.)
} 
emphasis community ownership as a strength by marketing The TSB Bank as the only New Zealand owned ${ }^{244}$ bank).

No performance is likely to be without detractors and detractions and this proved so for the Bank and the Trust during the interviews and the research process $^{245}$. For example, the dominance and prominence of the bank in Taranaki may be starting the seeds of some discontent, although much or some of this could be attributed to the tall poppy syndrome. Certainly there is some comment on the Bank's determination to ensure recognition for its support and involvement. Its name is attached to key venues in New Plymouth: The TSB Showplace (previously the New Plymouth Opera House), TSB Bowl of Brooklands, TSB Bank Bowls NZ Museum and the TSB Stadium are examples. There has been comment too on the smallness of the Bank's dividend payout. ${ }^{246}$ The political appointment of Trustees, while not directly an issue under the control of the Bank and the Community Trust, has few supporters, apart from, apparently, the Government of the day that makes the decisions.

The comparison of the Bank's and Trust's performance to other equivalent organisations will better ensure a relative judgement. However, in doing so, a qualification needs to be made that the TSB Bank is quite unique in New Zealand both in terms of size and ownership structure.

\section{COMPARISON TO OTHER BANKS}

What follows is not intended to be an in-depth analysis of the performance of the banking sector in New Zealand. Rather, it is presented as a snapshot that

\footnotetext{
${ }^{244} \mathrm{Up}$ to the recent arrival of kiwibank.

245 But, it should be emphasised, they were invariably noted as minor 'irritations' and usually qualified in the context of praise.

${ }^{246}$ For example, The Daily News feature article of 18 June 1993. This issue is discussed more fully further on in this study.
} 
may better identify the TSB Bank's performance and status. ${ }^{247}$ As would be expected for a sector vital to the county's economy, there are a multitude of documents to draw upon. Reserve Bank reports, analysis and regulations, the trading banks' annual reports and financial statements and their web-sites, and periodic reports such as those presented by the Centre for Banking Studies at Massey University have been the primary resources for this study.

Tripe (January, 2004) records that the then 6 banks, now five with the acquisition of the National Bank by ANZ in 2004, accounted for $86 \%$ of the banking sector's assets. The ANZ is the largest with total assets at last annual balance date in 2004 of $\$ 259,345$ million, just surpassing Westpac with $\$ 245,079$ million. BNZ with total assets of $\$ 39,310$ million is of a similar size to the ASB with $\$ 33,048$ million. By comparison the TSB Bank is small at $\$ 2,289$ million.

The ASB performs best in terms of ROE (return on shareholders funds) at an impressive $24.51 \%$. ANZ, BNZ and Westpac all achieve in the 19\% range with TSB Bank lower than those at $16.7 \%$.

While not a registered bank but a co-operative company ${ }^{248}$, the PSIS operates in the financial services field. With its smaller size it provides a comparison to the TSB Bank at the bottom end of the scale that would have the ANZ at the top end. The 2004 accounts of the PSIS ${ }^{249}$ record total revenue at $\$ 72$ million, total assets at $\$ 759$ million and a ROE of $11.4 \%$.

Kiwibank's performance is hindered by their recent arrival and they have yet to make a profit in a full year of trading. With $\$ 1$.3billion of assets at last

\footnotetext{
247 Comparisons are complicated by the overseas (Australian) ownership of the ANZ, ASB (Commonwealth Bank of Australia), BNZ (National Australia Bank), National (ANZ) and Westpac, and the relative size of the banks.

248 It should be acknowledged that because they are a co-operative company, they are more likely to restrict their margins of profit, thus reducing their returns. This may be inferred from the statements on their web-site.

${ }^{249}$ Refer web-site www.psis.co.nz.
} 
balance date, they were approximately two thirds the size of the TSB Bank.

In summary, this snapshot presents the TSB Bank as the smallest of the 5 well established trading banks with the lowest return on equity (but still very satisfactory), more akin to a regional bank but aspiring to be a national player specialising in personal banking, and a minor player only in commercial banking.

\section{MISSION AND VISION}

The nature of a community enterprise (which by definition ${ }^{250}$ both the Community Trust and the Bank are) is that their primary purpose is to seek to enhance the community in which they are located. While a community enterprise may seek in general terms to support and improve their community, it would be far more common to have a specific reason for existence. Thus the primary purpose for the establishment of the New Plymouth Savings Bank in 1850 was, as Scott (2002:4) records, 'the need for a safe depository for settlers' savings' and 'to encourage thrift'.

When the TSB Community Trust was formed in 1988 it followed the then Labour Government's classic formula of separating out policy (and distribution of profits) from operating. Thus, in general terms, the Trust is to act as owner of the Bank establishing policy, appointing its Directors and distributing profits back to the community. The Bank's role is to operate its trading services and generate the desired profits, as previously agreed with the Trust in annual or periodic business plans. The theory behind this separation policy is that the conflicts of different agendas are minimised, accountability regimes are strengthened and potentially greater efficiency arises from specialisation. None of these theories are absolutes and it is not unusual that the separation policy can create unnecessary duplication and inefficiency. ${ }^{251}$

\footnotetext{
${ }^{250}$ See section 1.2.

${ }^{251}$ For a more in depth treatment of these issues see section 2.3.1
} 
In reviewing the mission and vision statements of the TSB Community Trust and the TSB Bank through the lens of the interviews, the impression is gained that the Bank sets the scene. With its capable and professional management that perhaps is to be expected. The Bank's mission as recorded in their publication 'Your kind of Bank' is 'to achieve excellence in providing quality financial and related services to meet the continuing needs of New Zealanders, and to maintain the financial integrity of the Bank by the application of responsible and professional financial practice.' No leads are thus given to what may be the Bank's primary goals in terms of the definition of community enterprises and there are no links to historic roots. The sole emphasis is on performance.

The TSB Community Trust 5 year Strategic Plan approved by the Trustees in 2003 identifies their vision is 'To have created positive opportunities for Taranaki and its people' and their mission 'To support projects which make a positive difference'. Linkages with the Bank are provided by the first of 4 strategic goals where the Trust seeks to help community groups realise their ambitions 'and to encourage support for the TSB Bank'.

The impression that arises out of these documents is more separateness than cohesion. There are linkages as noted above and in the regular contact between the two as statutory and accountability requirements are met. But it is difficult to obtain an impression that there is a prime or overarching purpose that provides a reason for being in the nature of that proposed by Collins and Porras's seminal article Building Your Company's Vision (1996). The impression that is gained from the interviews and the documentation is that the Bank is there, committed to excellence and driven by a competent management team led by a long serving and committed Managing Director. It provides a dividend that is distributed in the best interests of the community. The community is grateful for what it receives.

A general reason for being such as making a positive difference for Taranaki and its people is of course a fine justification on its own and should suffice in most 
circumstances. But whether it provides a long lasting binding commitment is questionable. Arguably, since the Bank is pursuing a New Zealand wide policy of provision of services and yet the 'owners', and the sole recipients of the dividend, are the Taranaki people, a suggestion of conflict arises. That hint of inconsistency was fuelled during the interviews when one reason advanced for the smallness of the dividend payout was the benefit of a low profile.

A strong 'buy in' by the Taranaki people to the Bank's and the Community Trust's reason for being is particularly of benefit should its existence be threatened. At the time of the most recent interviews (March 2005) in New Plymouth, the sale of the Powerco ${ }^{252}$ shares by the New Plymouth District Council was still fresh in people's minds. There was a good deal of criticism and opposing comment by a number of the interviewees. That opposition was reinforced by casual discussion with Taranaki people. Yet the sale of the community's interest in Powerco occurred. One interviewee was certain that one day the same will occur with the TSB Bank. It could be argued that the strength of commitment to Taranaki ownership that occurred in the 1980s would suggest this to be unlikely; but then, perhaps not. The paucity of comment in the newspapers at that time hints at the possibility there may have been a silent agreement with the impetus being driven by a committed and determined group. If a sale of the Bank was to be equally driven, would there be an uprising of opposition? On balance the impression was gathered that there would be, but as the Powerco episode shows, it would not be certain. A stronger identification in the community's mind as to the Bank's

\footnotetext{
252 For very many years the New Plymouth City/ District Council owned and operated electricity assets. As part of the energy restructuring that occurred during the 1990s those assets were sold to Powerco and the Council maintained a significant shareholding interest in that Company. At date of sale in late 2004 it owned 120.6million shares, just over 38\% of shareholding. With two other community trusts (Taranaki Electricity Trust and Powerco Wanganui Trust), their shares represented a majority (53\%) interest. The sale generated \$259.4million for the New Plymouth District Council with the decision to sell largely based on investment return and policy. It appears minimal consideration was given to community impacts, for example, the Council's ability to influence energy policy in its district, including pricing policy. Substantive consultation with the community and ratepayers was not required and did not occur, although there was considerable media interest. For a treatment of these issues and the Controller and Auditor-General's investigation, see www.newplymouthnz.com and www.oag.govt.nz.
} 
and the Trust's reason for existence other than being there and a community support dividend, would seem to leave less to chance.

\section{OWNERSHIP AND THE COMMUNITY}

The TSB Community Trust is the legal owner of the TSB Bank. It is the only shareholder. The Trust is a charitable trust with its initial trust deed formed in May 1988.

A new deed was adopted in February 2001. The Community Trusts Act 1999 provides the continuing legal authority for the existence of the TSB Community Trust (and others) and details a number of requirements. For example, it reaffirms the defined area (and in effect, its beneficiaries) as that established in 1988 and generally known as the Taranaki region. In that area the Trust holds the assets on trust for charitable, cultural, philanthropic, recreational and other purposes beneficial to the Taranaki community.

Therefore, while the legal documents would define the TSB Community Trust as the owner of the TSB Bank, the beneficial owners, as recipient of the community support dividend, are the Taranaki community.

Ownership implies belonging, possession and relationship. Relationship implies a connection between the parties. These are significant issues for community enterprises and thus the thesis explores their complexities. ${ }^{253}$ Some discussion is desirable here particularly because this issue creates uncertainty on performance monitoring mechanisms in a world which, at least until recent times ${ }^{254}$, tends to view ownership of trading entities through a private enterprise vision ${ }^{255}$. That uncertainty was reflected at times during the

\footnotetext{
253 See section 2.3.2.

254 It is, perhaps, only over the last 5-10 years or so that new structures have started to proliferate, primarily to close the gaps of need created by globalisation and the market economy. For a treatment of these issues and the growth of the civil and solidarity-based economy see chapters 2 and 3.

255 McKinlay (1999 and 2001) addresses public and community ownership issues but, in the writer's opinion, with limited empathy for the nature of the organisations he discusses.
} 
interviews where the importance of the community ownership ranged from not important to very important.

Do then, the Taranaki community 'own' and have a relationship-connection with the TSB Bank and TSB Community Trust?

Few would disagree, and certainly those interviewed did not, that the geographic district of Taranaki has a strong sense of community, independence and pride. But a theme of the interviews, either inferred or stated, was that the community displayed few signs of overt ownership. One interviewee stated the public don't care so long as they can see the community benefiting. That view was supported to varying degrees by at least two others. It is a view that may be inferred from the lack of agitation on issues such as political appointments and dividend payout. But, equally, it could be inferred that the public is discerning, aware and satisfied; and that should a crisis (for example, of ownership) occur, it will step up and express its view. In the absence of that crisis, the $97 \%$ customer satisfaction rating from the Auckland University annual survey and an 'unequalled in Australasia and possibly internationally' (Annual Report, 1999) home base market share, point to a significant degree of involvement by the Taranaki community. The purist may argue that this is a commercial relationship but it would take a brave person to define a clear line between community pride and commercial benefit. As David Ogilvy on advertising noted (1983:117) '... research has found that people who know a company well are five times more likely to have a favourable opinion of it'.

Is McKinlay (1999:163) correct in his assertion that the TSB Community Trust does not have an effective mandate? The answer is yes if you seek a defined direct link ${ }^{256}$ between ownership and the community. But the answer is surely no if you acknowledge ownership is a much broader concept. As

\footnotetext{
256 Such a direct link would be shares where the owner would be free to move in and out of ownership to suit their needs and concerns. The argument here is that only then is risk monitored and market disciplines exercised over the efficient use of capital. But as Gates (1998) notes there are significant limitations to this premise. Another direct link between the community and ownership would be elections for Trustees as occurs for some community enterprises; for example, Licensing Trusts.
} 
Jensen and Meckling (1994) note, there are many things we own and are committed to which defy conventional economic definition. ${ }^{257}$

\section{ACCOUNTABILITY AND GOVERNANCE}

Trustees of the TSB Community Trust are appointed by the Minister of Finance. Directors of the TSB Bank are appointed by the Trust. Both Boards comprise 9 members and there is cross-membership with a maximum of three trustees also able to be a director (there are two at present).

The Minister of Finance's (on behalf of the Government) appointment of Trustees is a curiosity which probably has more to do with history and politics than any other logic. The historic justification was the Government's guarantee that was provided prior to restructuring in the 1980s. The logic now for the Minister of Finance's involvement is harder to find, even more so since the Government, with its Kiwibank involvement, has components of being a competitor. ${ }^{258}$ Claims that party politics influences the trustee selection process have regularly occurred, with some apparent validity. Scott (2002:32) suggests that 'it may be that the present government is overly keen to see its supporters in these (trustee) positions' while clearly admonishing that the selection of trustees should be 'a well-ordered process' for which 'party caucuses should not be a major influence.' The current chairman of the Community Trust noted some appointments could be political (interview 23 March 2004) while the previous chairman 'accused the Government of making a mockery of the appointment process, and weakening the effectiveness of community trusts' (Taranaki Daily News, 23 December 2000). Annual reports of the Community Trust have expressed dissatisfaction

\footnotetext{
257 Club membership is a better analogy for community enterprises. A subscription generally provides only a tenuous link and yet there can be a deep commitment to the club's activities. If the club is no longer meeting needs, membership invariably falls.

258 The competitive components would exist in the areas the TSB Bank trades, predominantly Taranaki. The perception of conflict of interest is probably greater than the reality. Both the Minister of Finance, Michael Cullen and the Managing Director of the TSB Bank, Kevin Rimmington, rejected any conflict existed. However, the then Chairman of the TSB Community Trust David Walter was concerned enough to write to the Minister because 'it appears to us that there may be an actual, potential or perceived conflict of interest,' a position that seemed to be supported by the Bank's solicitor. (See the Taranaki Daily News articles of 9 and 11 August 2001.
} 
with the appointment process (for example, 2003 and 2002). But the current MP, Harry Dunyhoven, rejected there was any evidence to suggest that political appointments were detrimental (interview 7 March 2005).

It would seem that this issue will remain a source of contention for so long as the Government continues to have an involvement. It is difficult to sustain a philosophical argument in support of the status quo simply because the Government no longer has an ownership component. There are a number of ways that the community could appoint/elect their own representatives. All that would seem necessary is a deed change. But a deed change is not likely to occur without the agitation of at least one, and perhaps all, of the ownership groups - the community, the trustees or probably least likely, the directors. None of the interviewees suggested there was any latent agitation; rather the present system could be more mildly described as an irritation. It may be that a factor why this has not occurred is the potentially greater uncertainty of a directly representative system - that is, the ballot box does not necessarily deliver people with the experience necessary to act as trustees. This concern of the uncertainty of the democratic system, if that is best replacement mode $^{259}$, is not uncommon by those in control. The benefits of a directly representative system by contrast are frequently seen to be more nebulous. ${ }^{260}$ The Bank reports in traditional corporate style and their annual reports and accounts are simple, effective and well-presented documents. Their web-site contains a mixture of marketing and information, and is again well arranged and effective. Disclosure statements and key information summaries provide in-depth and up-to-date data.

The Trust is required by the Community Trusts Act 1999 to publish their annual accounts and report, and a list of all donations, in a principal

\footnotetext{
259 Elections, like those that occur at the time of the local authorities' voting every three years for licensing trusts and other community enterprises like the Masterton Trust Lands Trust, are one form of direct representation and linkage between the owners - the community - and the TSB Community Trust. But there were other forms and combinations suggested during the interviews, for example, a nomination process by the community, and selection by a stakeholders panel.

260 McKinlay (1999) provides a treatment of some such views.
} 
newspaper of Taranaki (the practice adopted) or send a copy to each Taranaki household. They must also hold a public meeting not later than 31 October each year (usually poorly attended) and present a report on their operation and their financial statements.

There are regular meetings between the Trust and the Bank with quarterly statements presented by the Bank to the Trust.

Comments during the interviews nuanced the effectiveness of these processes but perhaps only to a minor extent. It is important to consider what follows as more in the nature of musing and in the context of the Bank's and Trust's achievements. Governance may be minimised if Trustees and Directors do not have all or enough of the skills to provide governance at the necessary level. This may not be so much a weakness if management is strongly competent but this circumstance is not the most desirable particularly where management may be headstrong or for example, determined to pursue a particular policy of doubtful benefit to the owner(s). Further, where Trustees and Directors are limited in their governance skills, it may be difficult for management to give credence to their judgement. What can then occur is that the governance role may be controlled. Management may assume parts of the role of the governance group. The danger then is that the roles become confused and the organisation loses the fine balance necessary for quality performance. It is important also to remember that there is no straight line where on one side lies governance responsibilities and on the other, management tasks. Rather, it is a hazy, meandering line that ebbs and flows in the particular circumstances of that time, and influenced by the skills and motivation of the parties. Governance is best seen as a team role where Boards of Trustees and Directors work with management to arrive at the best decisions possible. It is also a learnt role.

Where the ownership group does not adequately question their agents on performance and plans, something else is lost. That questioning is an 
important discipline for performance. More than one interviewee stated the community does not care so long as there is a good community support dividend, good services from which they benefit and take pride in, ${ }^{261}$ and no crises or excesses. That view, perhaps, is supported by the paucity of numbers who attend the annual general meetings of the Trust. This is a criticism that can equally be made of private enterprise, as Gates (1998:xix-) and others warn: a disengaged citizenry poses risks.

It is tempting to say, and notably so in the TSB's case, that all is well, nothing is broke and why waste energy when there are other pressing needs. Good people are committed to doing the very best they can and there are other checks and balances in place. That is a legitimate position to take, but in the writer's experience there are risks. People (and the available skills) change. Assumptions on what is best become a limited horizon. The absence of questioning creates a culture where it is difficult to question.

The involvement of the community in ownership is desirable. Ways to enhance the relationship between the community's agents and the Taranaki people can be explored in ways similar to those suggested by a number of authors: for example, Gates (1998), and Shuman (2000) but also many others for this is a contentious issue for which there are many opinions.

\section{DISTRIBUTION AND DIVIDEND}

In 2004 the TSB Bank's dividend to the TSB Community Trust was $\$ 5.2$ million which equated to $22.5 \%$ of tax paid profits earned by the Bank. The trend of dividends over the past seven years is shown in Table 2:

\footnotetext{
${ }^{261}$ For example, the quality and range of the Branches is a particularly smart move by the Bank because it provides a physical focus for the community. They take some pride in the fact that as other banks have been closing premises, their bank has been doing the opposite - reinvesting in them. Thus daily evidence (as they drive or walk past or visit) is provided that their bank is different and it cares for them.
} 
TABLE 2

\begin{tabular}{|c|c|c|c|}
\hline YEAR & $\begin{array}{r}\text { TAX PAID } \\
\text { PROFITS } \\
\$ 000\end{array}$ & $\begin{array}{r}\text { DIVIDEND } \\
\$ 000\end{array}$ & $\%$ \\
\hline 2004 & 23,147 & 5,200 & 22.5 \\
\hline 2003 & 21,409 & 4,785 & 22.3 \\
\hline 2002 & 18,450 & 4,100 & 22.2 \\
\hline 2001 & 16,640 & 3,450 & 20.7 \\
\hline 2000 & 12,791 & 1,900 & 14.8 \\
\hline 1999 & 11,264 & 1,675 & 14.9 \\
\hline 1998 & 9,370 & 1,320 & 14.1 \\
\hline
\end{tabular}

Factors other than levels of profitably that influence the size of the annual dividend are the need for strong capital adequacy ratios and the Bank's requirement for capital ${ }^{262}$. Because there is a limited ability to raise equity capital other than through profit retention, the Bank with the support of the Trust has maintained a policy of high retention of profits. Thus, Retained Surplus has risen to $\$ 137$ million as at 31 March 2004 .

The size of the dividend has been the cause of some concern in past years as the Taranaki Daily News articles of 29 May and 24 June 1999 record: 'The dividend paid to the Taranaki community by the TSB Bank has again come in for severe criticism as being far too low' (29 May 1999). As Table 2 shows, it was increased in 2001. There was general agreement amongst those interviewed that the level of dividend was appropriate enough although one person believed it should be in the vicinity of $30 \%$ of tax paid profits but not higher than $40 \%$. A payout in the low $20 \mathrm{~s} \%$ is quite conservative, if not overly so. A commercial trading entity predominantly exists to benefit its shareholders and dividend return is one important mechanism for doing so. It is not unusual for private

262 See the earlier section on REVIEW OF PERFORMANCE. 
enterprise companies to have payout policies in the $60 \%$ range. Westpac policy is $66 \%{ }^{263}$

There are a number of factors to consider in dividend policy and the range of variability is such that it is difficult to make relevant and meaningful comparisons. A Westpac is significantly different from a community owned bank. Profit retention must be more important for the TSB Bank. In the end run, if the community is not happy with the payout, it can agitate. There are no signs that this is likely to occur in the foreseeable future.

The community also benefits from the increased value of the Bank even if this is more notional for a community member. Nonetheless it is real in terms of value. Asset backing for a 50cents share was $\$ 7.36$ as at 31 March 2004 and it would be pure conjecture to attempt to arrive at a market value above that figure.

Distribution of the dividend is the major task of the Community Trust. Section 12 of the Community Trusts Act 1999 provides that the assets of the Trust may be applied for charitable, cultural, philanthropic, recreational and other purposes beneficial to the community, principally (but notably, not exclusively) in Taranaki. The Trust traditionally makes a small number of major grants (for example, $\$ 750,000$ to the Taranaki Hospice in 2003; $\$ 500,000$ to the Yarrow Stadium; $\$ 263,000$ to assist with the upgrade of the Hawera Water Tower;) and a multitude, annually around 1500, of smaller grants ranging from a few hundred dollars to a few thousand.

\section{WHAT IF...HAS THE ROAD TAKEN MADE A DIFFERENCE?}

What if the Bank had decided not to go it alone in 1986? What if it had cashed in its value and like the others became a passive investment trust?

\footnotetext{
263 It was difficult to obtain comparative figures for the other trading banks in New Zealand because of their overseas ownership which can tend to decide dividend policy on factors other than return to shareholders: for example, exchange rates, taxation.
} 
Much of what follows must be supposition for there are many uncertainties. But by following the pattern of what happened to comparative Trusts who chose this path we can make some relevant comparisons.

The two Community Trusts chosen to compare are neighbours: The Community Trust of Wellington and the Eastern \& Central Community Trust, one centred in Wellington, the other, the east coast and lower regions of the North Island with its headquarters in Hastings. While geographic proximity was the substantive reason for the choice, there is no reason to suppose that the choice of others would present a comparison any different. All but the Auckland Savings Bank and the Westland Trust Bank chose to combine into one Trust Bank which was eventually sold in 1996 to Westpac. Thus the nine Savings Banks that pursued the Trust Bank path would follow a very similar pattern. The Auckland Savings Bank absorbed Westland but here too the shares in the ASB were sold by the Community Trusts and today all except the TSB Community Trust are passive investment Trusts subject to the vagaries of investment returns.

Taranaki, Wellington and Eastern and Central's performance over the period of change from 1989-2004 is best measured by the movement in their net worth and donations provided to their communities:

TABLE $3^{264}$

COMPARATIVE PERFORMANCE

OF 3 COMMUNITY TRUSTS

\begin{tabular}{|l|r|r|r|}
\hline & TARANAKI & WELLINGTON & $\begin{array}{c}\text { EASTERN \& } \\
\text { CENTRAL }\end{array}$ \\
\hline Net Worth 1989 & $\$ 10,000,100$ & $\$ 4,999,700$ & $11,810,100$ \\
\hline
\end{tabular}

264 All information is provided from audited annual accounts. The net worth of Taranaki is an addition of the Community Trust and the Bank equity. Donations are the total of gifting to their community over these years, 16 in all. 


\begin{tabular}{|l|r|r|r|}
\hline Net Worth 2004 & $\$ 153,207,900$ & $\$ 36,305,500$ & $\$ 115,159,300$ \\
\hline Donations 1989-04 & $\$ 22,136,100$ & $\$ 26,551,900$ & $54,801,600$ \\
\hline $\begin{array}{l}\text { Total of Net } \\
\text { worth and } \\
\text { Donations }\end{array}$ & $\mathbf{1 7 5 , 3 4 4 , 0 0 0}$ & $\mathbf{6 2 , 8 5 7 , 4 0 0}$ & $\mathbf{1 6 9 , 9 6 0 , 9 0 0}$ \\
\hline $\begin{array}{l}\text { Benefit } \\
\text { Multiplier }^{265}\end{array}$ & $\mathbf{1 7 . 5 3}$ & $\mathbf{1 2 . 5 7}$ & $\mathbf{1 4 . 3 9}$ \\
\hline
\end{tabular}

The benefit multiplier is an attempt to compare the performance of the three Trusts who took two different paths. Its weaknesses are that it does not, and can not, asses the value of the donations to the community, and by extension, the value of the donations that were not made. Taranaki's donations are the smallest and their justification for that is canvassed in the Distribution and Dividend section. While it is logical to assume that some donations are more beneficial to the community than others, the assumption inherent in the benefit multiplier is that all are of equal value. ${ }^{266}$

The benefit multiplier is taken at one point in time so far as the value of assets are concerned. If extraordinary events occurred that impact on the point of time selected, then distortions may occur that at worst invalidate or may create various degrees of unfairness in comparisons. It may be argued this did

\footnotetext{
265 The benefit multiplier is arrived at by a simple division of the total of net worth and donations by the net worth in 1989. The validity of this calculation (and conclusions) rests on the justification that these Trusts were entrusted with certain assets with their communities as beneficiaries. These assets have either increased in value or been distributed to the community. The value the community thus receives is the benefit of the gift and the retained value of the assets (with their potential for future gifts).

266 In the absence of a credible mechanism to equate the value of donations, this is a reasonable assumption. It is not contended there are no mechanisms. The economic benefit of a donation to, say, the Wellington stadium can be calculated but, then, that is only the economic benefit. The well-being of a community is much broader than economic and, it is suggested, that should be the criteria for a Trust to judge the effectiveness of its community support programmes: to what extent is the community and its people better for the support? This is a large and complex issue which the writer a little thankfully (but also a little disappointedly for the task is fascinating) exits at this point. But solutions through credible and easy to calculate, and easy to understand, mechanisms are important Well-being indexes now being calculated and compared for countries may offer some methodological possibilities (see Prescott-Allen, 2001).
} 
occur. Most passive investment trusts took significant 'hits' in the value of their portfolios around 2001 and 2002 as equity markets retrenched in value. The Eastern and Central Trust, for example, saw their equity reduce from a high in 2001 of $\$ 148.9$ million to $\$ 115.2$ million in 2004 , a pattern similarly experienced by Wellington and others. During this same period the TSB Bank increased its book value from $\$ 98.3$ million to $\$ 147.2$ million. ${ }^{267}$ A recovery in equity markets has occurred over the latter two years and it may be argued that what resulted is a correction to overvalue in previous years. In summary, it is believed that the 2004 point-in-time comparison is fair and relevant provided that the trends over a period of time are recognised.

There is another factor that is potentially disadvantageous to the TSB Trust in the comparisons. When Wellington, Eastern and Central and others cashed in their shares their market value at that time was identified and realised. The TSB Bank market value is not known and is not necessarily reflected in retained earnings. It is much more likely that given their service performance and their high market share in their niche areas, they may command a premium on sale. Thus, the value shown in Table 3 is more likely to be understated than overstated. The two comparative Trusts, on the other hand, have their assets valued at market rates.

At the point-in-time of March 2004, the benefit multiplier indicates that the TSB Community Trust has quite significantly created more value for their community over the period 1989-2004 than has the Community Trust of Wellington and the Eastern and Central Community Trust.

\section{CONCLUSION}

Banking in New Zealand is very competitive, dominated in total market share by four Australian owned companies. Notwithstanding, and in part because of this, the TSB Bank has chosen its niche, sought excellence in providing its

\footnotetext{
${ }^{267}$ It is more than a little ironic that this pattern is contrary to the generally accepted wisdom that a broad diversity of investments is preferable to a concentration in one business or sector.
} 
services, and all but achieved that. The community ownership of the Bank has not been a deterrent in these accomplishments and on the evidence has been discernibly more a strength than a hindrance.

The strength of the Taranaki community spirit was a factor in the decision to retain trading in 1986 rather than to sell up and become a passive investment trust, as did the other 11 Trustee Savings Bank over the next decade. It is likely to be a significant factor in the years ahead.

The TSB examples well that there are no inherent structural flaws in the community enterprise concept that lead inexorably to demise. There are issues (ownership, accountability and equity) that must be addressed. Achieving acceptable performance is a constant everyday need. But the standards set in Taranaki are a model worthy of emulation. 
Chapter 8

\section{INVERCARGILL LICENSING TRUST}

A CASE STUDY

OF

COMMUNITY SUPPORT AND LEADERSHIP

The pilot interviews for this study were undertaken in March 2003. But it was not until over two years later in May 2005 that the bulk of the interviews were recorded. The study was researched and written over a three month period around that time. Supervisory comment then followed and the validation procedures with the seven interviewees occurred in September.

What follows in this study is almost too good to be true. Yet it fairly represents the ILT as it is today and its achievements over the past decade. The ILT is an organisation with status, both in Southland and in New Zealand. It has reached this point not without stumbles and some pain. But status it has achieved.

To many people in the 1990s, Invercargill and Southland was a depressing place to live. Like Eketahuna in the north, it was the butt of bad town jokes. Comparisons to Chernobyl and hillbilly towns ${ }^{268}$ could be laughed off to publicity, but in the latter part of the $20^{\text {th }}$ century, Invercargill was credited with the very doubtful honour of the fastest declining population of any city in Australasia ${ }^{269}$. Ray Harper, long time President of the Invercargill Licensing Trust and noted Southlander, is fond of recalling that it was a time when

\footnotetext{
268 Both these did occur. Brian Moore, an English rugby commentator made the first in May 2005 on a TV programme. The hillbilly comparison was the subject of a Southland Times article on 16 March 2004.

269 Editorial: The Southland Times, 1 July 2004. On 20 July 2002, the paper quoted Statistics New Zealand's estimate that if the existing trend continued the population would fall to 34,000 by 2021. Census statistics record that the population of Southland was 91,002 in 2001, a fall of 6,096 from $1996(-6.3 \%)$. During the same period New Zealand's population rose 3.3\%. Invercargill's population was 49,830 in 2001, a fall of 5,877 (10.55\%) from 1996. By June 2004, Southland's and Invercargill's population had risen to 93,600 and 51,700 .
} 
Southlanders turned to black humour: 'Would the last person out of Invercargill please turn out the lights. ${ }^{270}$

The echoes of decline had some parallels to cities throughout the world. A visitor would come away from Invercargill feeling it was an old city not quite knowing where that impression had come from and why it stuck. The town centre did contain buildings more reminiscent of $19^{\text {th }}$ century New Zealand but the parks and gardens, and the suburbs, did not present a picture of waste lands or even a city in decline as that so brilliantly and poignantly described by Bissinger (1997) in his tale of the rebirth of Philadelphia.

The people of the deep south of New Zealand have always had a reputation of resilience and pride. As a community they are not prone to defeatism and undue pessimism. But farming incomes, the mainstay of the Southland economy, had been indifferent to poor for much of the 1990s. Housing was cheap with demand in the latter part of the decade far less than supply. ${ }^{271}$

What occurred over the next few years is a remarkable story of resurgence ${ }^{272}$. As would be expected of the rebirth of a city and region, there was no one factor. The significant improvement in farming commodity prices underpinned events. The 6 times national success of the Southern Sting netball team provided a feel good factor. This was a period of civic renewal with the construction of Stadium Southland, the Civic theatre renovation, centre town makeover, swimming pool extensions and the Rugby Park upgrade. The outstanding success of the zero fees scheme at the Southland Institute of Technology contributed, as did the renown of the Mayor with his enthusiasm and popularity.

\footnotetext{
270 Interview 10 March 2003.

${ }^{271}$ Fred Tulett, the editor of The Southland Times records that when he came to Invercargill in 1998, over 550 houses were for sale (more had been withdrawn because of the difficulties of finding a buyer). He purchased his home for 25\% less than the rateable value (Interview, 16 May 2005).

272 John Prendergast, CEO of the Community Trust of Southland, in a presentation to the Philanthropy New Zealand 2004 conference quotes Bernard Salt 'a noted Australian demographer' : '...Invercargill is the
} 
One institution, the Invercargill Licensing Trust (ILT) has been at the fore of all these changes: 'the absolutely vital and dramatic force and stimulant for change' has been the ILT. ${ }^{273}$ This study looks at the leadership and community support role of the ILT over the latter years of the 1990s and the first few years of the new millennium in the context of its role and performance during its more than 60 years of existence. This emphasis is deliberate. The impression was formed, firstly during the initial interviews in March 2003 and then consolidated during the May 2005 research and interviews ${ }^{274}$, that the ILT had now come fully of age, well aware of its role, and determined to pursue and extend the limits of its capabilities and potential. Ray Harper well summed this up: 'Doing something good for our community is our first responsibility' and 'there is very little that (publicly) goes on in Invercargill that we (the ILT) are not involved in, ${ }^{275}$

A beginning is first presented. Its mission and vision are considered particularly in the context of the original ideals and legislative powers. A review of performance for the last 10 years (including ILT's associated charitable trusts) follows. Ownership and the community and accountability issues are discussed. The study then chronicles the distribution of community support with particular emphasis on two points: firstly, the major schemes the ILT has either initiated or facilitated, and supported, and the quantum of donations; and secondly how this function integrates into the business enterprise. ${ }^{276}$ Finally, a counter case is presented of the concerns of opponents and critics.

\footnotetext{
only local authority area in Australasia in 27 years of tracking population trends... that he has seen reverse a negative population trend.' The writer has not verified if this is true.

273 Interview 17 May 2005 with the Mayor of Invercargill.

274 In all, 8 interviews were recorded: Alan Dennis, ILT Trustee since 2001 and President from 2004; Ray Harper (2), Trustee for 18 years and President of the ILT from 1995-2004; Greg Mulvey (2), the general Manager of the ILT since 1988; Tim Shadbolt, Mayor of Invercargill; Penny Simmonds, Chief Executive of the Southern Institute of Technology (SIT); and Fred Tulett, Editor of The Southland Times. In addition, Acton Smith, Managing Director of H\&J Smith and Chairman of the Southland Building Society, provided written answers to the same questions posed to the interviewees.

275 Interview, 10 March 2003.
} 
To discover, validate and explain, this study draws upon open-ended, semistructured, recorded interviews where a list of questions were provided before-hand. Newspaper archives, annual accounts and reports, letters to the editor, minutes, correspondence files and a variety of other reference works as listed herein were extensively utilised. The methodology framework and justification is detailed in chapter 4 but it is perhaps important to emphasise the necessity recorded by a number of authors (Yin, 2003; Sechrest et al, 1996; Stake, 1995; Garson, 2001) to ensure a rigorous triangulated approach to validation. ${ }^{277}$ Those interviewed were also asked to review the draft report. Finally, the writer benefited from an association of over 30 years with employment by a sister Trust, Masterton, which created a unique opportunity for observation and understanding. ${ }^{278}$

\section{A BEGINNING}

The establishment of Licensing Trusts in New Zealand, and Invercargill as the first Trust, must be seen against the background of the country's history. In the 1940s New Zealand was even more so a young country, then barely 100 years old when traditionally measured. Much of its pioneering spirit or its aftermath remained.

In the early history of New Zealand a hotel was inevitably one of the first buildings erected in new settlements. The lives of the early settlers were often ones of difficulty and almost always of hardship and deprivation. Hard drinking and the often consequential drunkenness can be seen as a reaction to the times. Abuses, common during the $19^{\text {th }}$ century, brought increasing

\footnotetext{
276 Section 2.3.1 of the thesis debates the validity of the premise that has philosophically underpinned a good deal of legislation in New Zealand since the 1980s: that commercial goals should (always) be separated from social/community goals.

277 Multiple lines of enquiry are converged to validate and strengthen the evidence.

278 The importance of this long association is more understated than overstated. Its reference and validity is included here so as to give credence to an important tool of research - disciplined observation. As Putnam (1993:12) notes in his research of regional democracy and government in Italy you 'experience its customs and practices, its successes and its failings, as those who live it everyday do.' But as Putman warns, it is also important to be constantly aware 'of the difference between insight and evidence.'
} 
legislative restrictions (De La Mare, 1981). The prohibition lobby gained in strength and in 1905, Invercargill, along-with a number of other areas went dry. ${ }^{279}$ It was to be almost 40 years before restoration of liquor licensing was carried in Invercargill by a very small majority of 45 votes (Lind, 1994). ${ }^{280}$

Restoration may have been carried but a minefield of issues now had to be settled. Was private ownership of licences to be allowed with its perceived potential to revert to the excesses of the past? Was it to be municipal control or even possibly state control?

Municipal control was rejected by the City Council. It was left to the Prime Minister of the day, Peter Fraser, and his Labour Government to provide the innovative leadership. Lind (1994: 24-25) well sums up the parliamentary debates that ensued: '(Peter Fraser) would like to see a new experiment in Invercargill, with capable local men, having only the community at heart and with no thought of personal profit for themselves, formed into a trust to operate a totally new system.' On 17 April 1944 the Invercargill Licensing Trust Act came into being. Three aspects therein are notable. There was to be a concentration on providing 'model hotels' and thus seek to avoid the poor facilities of the past which tended to lead to excesses. The 'interests of the public well-being' should be a constant consideration. Lastly, the Act provided for 'distribution of the profits for public purposes.' While the Invercargill Licensing Trust Act has since been absorbed into the omnibus Sale of Liquor Act 1989 and two of these three expressed provisions disappeared, their spirit is strongly honoured today.

Perhaps the ideals and aspirations of the legislation can be summed up by the recorded words of one Member of Parliament (Archer, Hansard 1944: 853): 'It seems to me to be the greatest measure that has been passed since the social security legislation was placed on the statute book. I believe it will enbance the reputation of New Zealand throughout the world.'

279 That is, liquor licences were abolished and liquor could not be sold in that defined area. 
During the better than 60 years that have now elapsed, the ILT has passed through periods of basking in the enthusiastic support of its community and at other times suffered its derision. It has benefited from the exceptional skills of some gifted executives and trustees, and survived periods when the talents available were found wanting. Not surprisingly, there is a strong correlation between performance and people ${ }^{281}$. Today ${ }^{282}$, the ILT operates 5 accommodation businesses (one in Dunedin), 13 taverns/cafes/bars, 5 liquor stores and a catering unit. Revenue in 2004 was $\$ 77.4$ million, profit $\$ 12.5$ million from assets employed of $\$ 70.5$ million. Donations of community support totalled $\$ 6.7$ million.

\section{MISSION AND VISION}

The ILT state their purpose is to 'provide quality accommodation, food, beverage and entertainment facilities for the residents of, and visitors to, Invercargill' and 'to provide an effective and efficient corporate structure to ensure that our products, services and facilities are maintained to the highest standards ensuring continued profitability and thereby creating ongoing benefits to the local community. ${ }^{283}$

Section 187 of the Sale of Liquor Act 1989 now contains the legislative authority for the ILT to set objectives. Those powers are closely comparative to the ILT's mission statement. Section 189 of the Act, which has changed little from the 1944 provision, provides the power to distribute profits to the Invercargill community.

In a more human and personal way, Greg Mulvey and Ray Harper simply, yet intensely, say 'everything we do is with the good of the community in mind. ${ }^{284}$ They

\footnotetext{
280 The votes had to pass a threshold of $60 \%$. Were it not for the overwhelming support of servicemen overseas $(81.5 \%)$ it would not have been reached.

${ }^{281}$ For a historical treatment of some of these events see Lind (1994).

282 As recorded in the ILT's 2004 annual report and web-site www.ilt.co.nz.

283 Source: 2004 annual report.

284 Interviews 10 March 2003.
} 
freely give examples.

\section{BOX 1}

I spoke at the Multiple Sclerosis (Society) on Monday night at their annual meeting. They had about 60 there. If you can get better people you find them. Now these are people who are really up against it. Now a few years ago they were broke and they very hesitantly rang up and asked if I could have a cup of tea with them. They didn't stick out their hand and they were so bloody nice and said 'Look, can you belp us?' 'How much?' '\$48,000.' 'We've got a meeting on Thursday. I'll let you know on Friday.' That night we passed the \$48,000. They've never forgotten it.

Ray Harper: interview, 10 March 2003.

Acton Smith reinforced the ILT's aspirations and success: 'The importance of the role the ILT has played should not be underestimated. They have often been a prime mover, and their support is carefully given, and in whatever support they give their objective is always to improve the lot of the people of Invercargill. ${ }^{285}$

Everything we do is with the good of the community in mind.' You can not sit through interviews with Greg Mulvey and Ray Harper and not believe this is what they believe and what they have sought to achieve. There is an intensity to their words and their delivery. In Ray Harper it is reflected in his stories of community involvement that is extensive and acutely intuitive. His sporting, business and community experience gives him an almost immediate awareness of the issues and an understanding: for example, his response to the approach on the zero fees scheme from (SIT) was a swift 'We have to go with this. ${ }^{286}$ In Greg Mulvey there is an intensity that vibrates. For him 70-80 hour weeks are normal. There is little that concerns the ILT and the community that he lets escape his attention. A challenge or threat, perceived or real, is personal. Should, for example, a report appear in The Southland

\footnotetext{
285 Letter of 9 May 2005.

286 Interview Penny Simmonds 16 May 2005.
} 
Times that appears to him unfair or critical, a meeting could be arranged with the Editor to discuss the area of concern.

Here, then, is the heart of the successes of the past few years: a deep commitment to the community and to the enterprise that transcends self. Understanding why this is so gives insights into both the justification for community enterprises (the theoretical and philosophical underpinning) and how they work in practice.

When asked why he would decide to become involved in the ILT at an age when most would be thinking of a quieter life, Ray Harper typically understates his reasons: I was approached and asked to do so (in 1986)' ${ }^{287}$ The ILT was not performing well. There were conflicts with the community in its authoritative style and change was perceived as necessary. The 1986 elections saw the long-standing chairman for 20 years not returned as a Trustee and Ray Harper elected. In April 1988 Greg Mulvey was appointed to the senior executive position as General Manager. Ray Harper took over the Presidency in October 1995.

A successful businessman and noted sportsman and administrator, even his comment that 'there must be a bit of the socialist in me 288 does not do justice to his deep and extensive commitment over the years. It is very evident that he believes in the concept of community enterprises but of even more significance is his not expressed determination to contribute his skills primarily his knowledge and leadership.

Greg Mulvey's intense commitment firstly to all things ILT and secondly to Invercargill and Southland, certainly has parallels to other forms of institutions (for example, private enterprise) and success (for example, sportspeople). Competitive people of this calibre and skills are not

\footnotetext{
287 Interview 17 May 2005.

288 Interview 10 March 2003.
} 
uncommon even though this does not make them less valuable. But it is the community component that provides the difference. If it (the ILT) was only commercial, there would not be the same motivation to give up so much time to community events. ${ }^{289}$ Perhaps his recorded assertion that he was driven by an intense desire and belief that the ILT is worthwhile is best summarised by a request made to him by a prominent and elderly Southlander: Please protect the ILT so that it will continue to be available to do something for our children's children. ${ }^{290}$

\section{REVIEW OF PERFORMANCE}

Key performance indicators for the last 10 years of the ILT's enterprises are shown in Table 1:

TABLE $1^{291}$

\begin{tabular}{|l|r|r|r|r|r|}
\hline YEAR & $\begin{array}{r}\text { TOTAL } \\
\text { INCOME }\end{array}$ & $\begin{array}{r}\text { TOTAL } \\
\text { ASSETS }\end{array}$ & $\begin{array}{r}\text { TOTAL } \\
\text { EQUITY }\end{array}$ & $\begin{array}{r}\text { TAX } \\
\text { PAID } \\
\text { PROFIT }\end{array}$ & $\begin{array}{r}\text { RETURN } \\
\text { ON } \\
\text { EQUITY }\end{array}$ \\
& $\mathbf{\$ m}$ & $\mathbf{\$ m}$ & $\mathbf{\$ m}$ & $\mathbf{\$ m}$ & $\mathbf{\%}$ \\
\hline 2004 & 77.4 & $70.5^{293}$ & 58.7 & 12.5 & 22.40 \\
\hline 2003 & 73.4 & 65.2 & 53.0 & 11.7 & 23.54 \\
\hline 2002 & 63.8 & 55.8 & 46.5 & 9.6 & 21.67 \\
\hline
\end{tabular}

289 Interview 16 May 2005.

290 Interview 16 May 2005.

291 All information has been gathered from the annual accounts of the Invercargill Licensing Trust, the Invercagill Licensing Trust Charitable Trust and the Invercargill Licensing Trust Sports Foundation. As the ILT's accounts note, the substance of the Charitable Trust and the Sports Foundation are as subsidiaries of the ILT. Both were established by the ILT under Trust Deeds to better administer aspects of operations in ILT premises, predominantly gaming activities. 3 Trustees of the parent ILT Board are also Trustees of the Charitable Trust and the Sports Foundation along-with the Mayor of Invercargill, the General Manager of the ILT and the solicitor to the ILT.

292 Calculated on average equity, that is, the average between opening equity at beginning of the year and the closing equity. Note that this percentage return would be affected by the apparently conservative valuation of some assets as noted in the following note.

293 The ILT may be classed as a conservative recorder of the value of some of its major assets. As the annual accounts record, land, buildings and shares may be included at cost when market value may be significantly greater. If the more recent valuations are considered, $\$ 11.4$ million could be added to total assets and total equity. 


\begin{tabular}{|l|l|l|l|l|l|}
\hline $2001^{294}$ & 54.4 & 49.6 & 42.2 & 6.8 & 16.71 \\
\hline 2000 & 45.4 & 45.1 & 39.2 & 5.6 & 14.20 \\
\hline 1999 & 43.5 & 45.7 & 39.7 & 5.6 & 14.58 \\
\hline 1998 & 44.2 & 42.3 & 37.0 & 4.5 & 12.57 \\
\hline 1997 & 45.7 & 40.1 & 34.6 & 4.5 & 13.55 \\
\hline 1996 & 46.2 & 37.7 & 31.9 & 7.6 & 26.21 \\
\hline 1995 & 43.5 & 31.7 & 26.2 & 3.8 & 10.61 \\
\hline
\end{tabular}

The Table presents a pattern of good to very good results. The early years of the decade are constrained by the depressed environment of the Southland economy while the years 2002-2004 benefit from its buoyancy. But it would be wrong to infer that these consistently good results are mainly a reflection of the economy. Good management and governance, and good business options chosen, can be fairly pointed to as more significant factors. The Balance Sheet is strong with no debt and very high equity/ownership ratios. Returns on equity for the last three years averaging $22 \%$ are outstanding.

A critic may say that the ILT benefits from a monopoly position in some sectors of its business, the results are inflated by gaming profits and the ROE is made to look better by a conservative asset valuation policy.

Restricted competition rights apply in the Invercargill area. The effect of this is that the ILT has the exclusive rights to hold on-licenses for hotels and taverns, and off-licences other than for clubs and vineyards. Thus, one result is that supermarkets are precluded from selling beer and wine. ${ }^{295} 296$ These

\footnotetext{
294 The ILT has only consolidated the Sports Foundation's and the Charitable Trust's results from 20022004. For the years 1995-2001 the writer did so using a simple addition of the results in the 3 sets of accounts. There could, however, be some inter-transactions which could have a small effect on the key indicators shown in the Table. They would not be material, and would not detract from the trends presented.

295 For a definition of terms see the Sale of Liquor 1989. Sections 215 and 216 of the Act contain the provisions relating to competition polls.

296 This is not to say there is no competition or even that competition is limited. Greg Mulvey noted during the May 2005 interview there were over 100 liquor licences held other than by the ILT.
} 
preferential rights provide the ILT with trading benefits. But it is the community that decides the level of competition they wish in their area. With the rights come restrictions and responsibilities. The ILT can not trade in liquor outside its defined area and it accepts it should provide services and outlets to cover the area and a wide range of entertainment and hospitality needs, some of which provide limited profitability and low returns on assets employed. ${ }^{297}$ It accepts too, as recorded in the interview with the ILT's General Manager and reinforced by the two Presidents' interviews, it should be a good neighbour particularly sensitive to conflicts and concerns it may create.

\section{BOX 2}

We do operate in a glasshouse. We accept we're under a microscope. A monopolistic structure will bring intense scrutiny from its own people. We are far more aware of issues. You bave to be to protect yourself from criticism.

Interview: Greg Mulvey 16 May 2005

Notably, none of non Trust people interviewed were against the position that applied in Invercargill, and all were supportive of the ILT. Greg Mulvey stated their polling suggested $70 \%$ community support for the competition restrictions that apply in Invercargill.

The contention that gaming profits are not 'true' trading profits is a curious one. It surfaces consistently at the time of competition polls when the supermarket chains seek to lessen the impact of the Licensing Trust by criticising its performance. The argument advanced is that because gaming profits must be distributed to the community, they should be excluded from trading performance; in effect, the Licensing Trust acts merely as a trustee for the profits. There is little legal or any other validity to the contention. The

297 For a more extensive treatment of the complexity of issues relating to the competition polls legislation, see the case study of the West Auckland poll in February 2003 in chapter 6. 
gaming profits must first be generated by investment and good management. They (the profits) are 'owned' by the Invercargill Licensing Trust Charitable Trust and the Invercargill Licensing Trust Sports Foundation and the parent body, the Invercargill Licensing Trust, is required to consolidate the results into their annual financial statements. ${ }^{298}$

The conservative valuation policy may appear to understate the value of assets with the follow on effect of understating equity and overstating return on equity. The valuation of licensed premises is fickle, dependent as it is on returns generated. Hospitality trading is fashionable and sensitive to market changes. The ILT may also argue that with the possibility of a competition poll challenge ever present, a conservative policy is justified.

None of the interviewees could point to any waste and inefficiency that can be associated with monopolies or privileged positions. All believed that the ILT was efficiently, even frugally, managed.

\section{BOX 3}

As a public good I think they're great. I'm really concerned that I think that. ${ }^{299}$ It's with real soul searching... we examine their activities very closely. And we do so very publicly.

Interview: Fred Tulett, Editor of The Southland Times, 16 May 2005.

\section{OWNERSHIP AND THE COMMUNITY}

The degrees and subtleties of ownership are an important issue for the ILT. At one extreme they impact upon its continuing existence either in its present form and level of trading (and related here is the important question of where does the ILT go next for its continuing growth: with $\$ 25$ million of short term cash deposits in its treasury this is not a light debate) or with the carrying of a

\footnotetext{
298 Again, for a more extensive treatment of this matter see the West Auckland case study in chapter 6.

${ }^{299}$ For sake of clarity, this wry comment should be seen in the context of his role of Editor.
} 
competition poll, changes to its trading base that may see more investment out of Invercargill. A further consequence of such a poll would likely be a fundamental change of emphasis to more targeted community support. Another degree of contest is the privatisation debate. With the present Labour Government in Government, and openly supportive of community enterprises, further privatisation is not on the political agenda. Given the depth of anti-globalisation feeling and the strength of growth of the civilsolidarity sector world-wide, it is difficult to see a policy reversal in the foreseeable future, but Governments and policies do change. Communities are well aware of the often forced changes of the 1980s and 1990s that left them with less control over their future and frequently worse off. ${ }^{300}$ And lastly, the subtle degrees of ownership have importance to ILT because a committed and satisfied owner will positively support and not confront. These, then, are the issues canvassed in this section.

\section{BOX 4}

Whilst the community understands it 'owns' the ILT, I personally do not think the individuals feel they have a share of that ownership. In many ways it is not unlike the situation the SBS ${ }^{301}$ faces (I am chairman of SBS) where the members know that the SBS belongs to them but they do not have a sense of ownership in the same understanding that they have ownership of their house or car or other assets. However, if the question is to protect the ILT if it was offered for sale, I would suspect that a similar response would occur within the community of resistant to the sale the same as we had in 1991 when the SBS was threatened with sale to Westpac.

Acton Smith: letter of 9 May 2005

300 Greg Mulvey referred to the bitterness and betrayal the Invercargill community still feel over the demise of Trust Bank Southland. The Mayor, Tim Shadbolt commented that 'a lot of people were burt by privatisation'

301 Southland Building Society is an iconic Southland institution formed in 1869 and now providing a range of banking services and home loans to its members throughout New Zealand. 
McKinlay (1999), in questioning the bonds of ownership and the accountability mechanisms for the considerable Community Trust resources in New Zealand ${ }^{302}$, argues ownership usually comprises the right to receive some value from the community assets and the right to have a say on how the assets will be used. To these can be added the deeper, in some ways almost spiritual, components of pride and association: we have a sense of ownership when we relate with warmth. An example here is New Zealanders' almost obsessive love of the All Blacks. When they win well, we take considerable pride and satisfaction in our ownership of them. When they lose, a cloud of doom almost settles on the country. Ownership also implies belonging, possession and relationship. Thus, it can be seen that ownership has a number of layers and contexts, and can be immensely complex. It is too simplistic to view community ownership at the level of rights and responsibilities. Yet the challenge is considerable. How do you take these other, almost intangible yet very real, components - pride, association, belonging, possession and relationship - and make them meaningful for community enterprises?

The right to receive some benefit from the community assets and the right to have a say over their use is addressed first. Distribution of community support is the subject of a separate section further on in this study but it is worth noting at this stage as an overview Greg Mulvey's comments on their periodic polling of the community: 'Our research shows that $85 \%$ of people think that the Trust either does well or very well in the way it distributes its funding. ${ }^{303}$ The right to have a say on the future of the ILT has at least two aspects: firstly the triennial elections of trustees and secondly periodic comment and agitation.

\footnotetext{
302 He records (:1) that ' $\$ N Z 5$ billion (\$NZ1400 for each New Zealand resident) is beld on behalf of consumers and communities in a series of community trusts.'

303 Interview 16 May 2005.
} 
BOX 5

You have ultimate ownership in that you can change who is on the Trust - the Trustees every 3 years and sometimes that is hotly contested and sometimes it is not.

Interview with Penny Simmonds: 16 May 2005

Periodic elections can be a powerful tool for regulating behaviour, although critics can be sceptical over their effectiveness. A cynicism that popularity and presentation skills are more likely to bring about election success than skills appropriate to the task is a common comment of the critics along-with an assertion that three years can be a long time if a poorly skilled board is elected. But democracy does also frequently deliver effective governance. Penny Simmonds' comment that Ray Harper's election to the ILT Board in 1986 may have been in recognition of the community's perception that it needed strong leadership at a time of indifferent or poor performance, may be such an example.

Letters to the editor, critical media review, community agitation and comment to management and trustees can also be effective in monitoring performance and facilitating change, particularly when the goodwill of the community is required to maintain the status quo under a competition poll. Review of the ILT's newspapers clippings file attest to a lively interest in Trust affairs. While these un-structured and non-regimented (in legislation or regulations) forms of community involvement are often discounted, the practitioner who must address them would rarely do so. ${ }^{304}$

How does the community relate to and understand the intangible components of pride, association, belonging, possession and relationship? ? $^{305}$ The answers in the interviews gave glimpses of insights in ways that were

\footnotetext{
304 The statement is born out of experience. The writer has a healthy respect for the power of local politics. It was mirrored frequently during the interviews with Greg Mulvey.

305 The theoretical underpinning for these concepts is contained in chapter 2.
} 
personal to them, not unsurprisingly, for ownership is most often personal and a 'felt good'. At times it is a collective 'felt good' as when Invercargill people talk about the remarkable success of the Southern Sting netball team, 6 times winners of the National Championship.

\section{BOX 6}

The Sting came to us soon after they started - said they needed a new floor. The indoor facilities in Invercargill were poor. I could see they needed a new stadium. So we built them one. It took us 4 years. The ILT organised it all - we organised it all in this office. I had a great committee. Still have. It cost us $\$ 11$ million. We put in half. Now when the Sting play at home we pack the Stadium out - 4200 people. It brings in $\$ 160,000$ each game. There were 87 major events in the Stadium this year. We are now building major extensions - an indoor cycling velodrome, only one in New Zealand.

Ray Harper: interview 10 March 2003

Mayor Tim Shadbolt noted that voting patterns for the ILT were healthy.

BOX 7

They have real political stability (despite challenges from extreme groups). There's an incredibly bigh voter turnout - $71 \%{ }^{306}$ I think there's a strong sense of ownership. Every indicator I look at there's strong commitment to and a strong belief in the Trust. The overwhelming support - like 10\% don't care, 10\% oppose, 80\% like what they've got and that's reflected by the stability that you see. If there's widespread unhappiness like I experienced in West Auckland, you get real instability in every election and everything changes.

Mayor Tim Shadbolt: interview 17 May 2005.

306 Electors interest in the ILT over the past 7 elections (1986-2004) has varied from a high of 18 candidates (for the six positions) in 1995 and 1998 to 9 in 1989 and 2004. Votes cast have steadily fallen from 106,571 in 1995 to 74,430 in 2004. The electoral officer for the Invercargill City Council (and thus the Invercargill Licensing Trust also) stated voter turnout in 2004 was 54.6\%. 
The points of contact each member has with the ILT impacts upon their individual and collective opinion.

BOX 8

But I would think the criticism now is significantly less than it was 4-5 years ago. With the amount of money they are giving out the number of people touched by the ILT is pretty significant. There wouldn't be many people in the community that haven't through some means been touched by the funding that's given out. And also the facilities they have. There wouldn't be many people who... wouldn't be grateful for the (range of) facilities.

Penny Simmonds: interview 16 May 2005

Cohen's insight (2000) that people assert and defend their image of community when they perceive any attack or challenge as personally impacting on their own sense of self, highlights the importance of the intangible components of ownership. Pride in the ILT's achievements, association through use of facilities and receipt of benefits, and the sense of belonging ${ }^{307}$ achieved by an appreciation of the ILT's importance in providing the quality of community life they (the people of Invercargill that comprise the ILT community) love and seek to maintain, are complex, multi-faceted and interwoven concepts daily being translated into practical reality. They are present in large part in Invercargill. The witness to this was not just in the interviews and written words. They are reflected in the vigour of mayoral and community reaction to challenge; in the turnaround of falling population; and in the lack of supermarket challenge to the ILT's preferential trading rights, the only area in New Zealand for this to occur.

\section{ACCOUNTABILITY}

Mechanisms of accountability seek to complete the contract between beneficiaries (the community) and governors (the elected Trustees and their

307 The belonging is to, that is, being part of, and of, that is, membership. 
agents, management). They achieve importance because they endeavour to marry expectations with results. In effect, the community of Invercargill have certain expectations which the governing group are expected to discern and then deliver. Should they not, conflict arises, sometimes solved by acceptance by one party of the other's view or sometimes by compromise achieved by discussion, and sometimes by rejection if the expectations are seen to be unreasonable, unachievable or not acceptable (to the governing group).

The common expectations are prudent management of resources free of excess and undue personal gain (the good stewardship model), integrity of intention and action, delivery of benefit both in the trading facilities and services and community support, and responsible actions (the good neighbour concept).

To discern performance on these expectations, accountability mechanisms can be expressed or implied. Expressed provisions are defined in the Licensing Trusts section of the Sale of Liquor Act 1989, notably the requirement to produce and have audited their annual report and financial statements, and annually publish a list of community support donations. Both requirements are well presented by the ILT and readily available even if demand is minimal which in the writer's experience is only likely to change if controversy occurs. Lack of demand may therefore, somewhat perversely, be seen as a vote of performance acceptance.

Implied mechanisms are periodic reporting through the media or brochures on events or intentions of importance, accessibility of management and trustees, and public functions.

It was clear from both the newspaper clippings file at the ILT and the interview with the Editor of The Southland Times that there is lively interest both ways: the ILT accepts it is high profile and is determined to manage the media's impact and interest, and the media is keen to hold it accountable. Accessibility of management and trustees, notably the President, is well 
exampled by the frame (Box 1) quoting Ray Harper's cup of tea with the Multiple Sclerosis Society. When President he would spend two to three nights a week out speaking to groups. He and the General Manager are high profile people in Invercargill, well known and readily accessible at their homes.

BOX 9

A lady came to see me in Arrowtown. She had heard my crib was there. 'You're Ray Harper, aren't you? I want to thank you from the bottom of my beart.' I asked what for? 'Our older daughter could never have gone to University, we just never could have afforded it. She can now qualify in accountany (because of ILT's support of the zero fees scheme at SIT).' I said - you've made my day.

Ray Harper interview: 17 May 2005

The present President, Alan Dennis, continues this accessibility. He believes the issues now for Invercargill have passed from the provision of 'things' like Stadium Southland and the Civic Theatre to quality of life issues like education. As a former principal of a large school he understands better than most the needs of that sector. The ILT has recently approved funding of \$2million for Invercargill's schools. The vision is for the City's schools to be the best in New Zealand and the path, Alan Dennis believes, is through the teachers. Thus the fund is administered by a small group he chairs which, generally within two weeks, can quickly decide on proposals placed before them by schools. These proposals can not be for something the Ministry of Education normally funds, and must help teachers improve their skills. Notably, the formula that ILT believes in is continued: maintain an involvement in the major community support schemes.

\section{DISTRIBUTION OF COMMUNITY SUPPORT}

The high profile ILT has received from the major schemes it has supported in 
recent years - the free fees at SIT, Stadium Southland, the Civic Theatre, the swimming pool upgrade and extensions, Rugby Park upgrade, annual support of the Southern Sting and Southland rugby - is but one aspect of a wideranging community support. Arguably, as the interview with Penny Simmonds recorded (see Box 8), it is the multitude of smaller donations to 'approximately 500 Invercargill organisations... covering all sectors of our community'308 that make the most impact. Table 2 records the quantum of donations for the past 5 years and the relationship with profits:

TABLE 2

\begin{tabular}{|c|r|r|}
\hline YEAR & $\begin{array}{r}\text { TOTAL } \\
\text { DONATIONS }\end{array}$ & \% OF PROFITS \\
& $\mathbf{\$}$ & $\mathbf{\%}$ \\
\hline 2004 & $6,748,000$ & 54.1 \\
\hline 2003 & $5,231,000$ & 44.6 \\
\hline 2002 & $5,226,000$ & 54.7 \\
\hline 2001 & $3,861,000$ & 56.8 \\
\hline 2000 & $6,100,000$ & 108.9 \\
\hline
\end{tabular}

These figures, compiled from the annual financial statements of the ILT, do not include some other components of community support, for example, the extensive sponsorship programmes and both management and trustee time in administering.

308 Annual Report 2004:5. 
BOX 10

I would spend $40 \%$ of my time (on community support). My assistant General Manager would spend 30\%. Trustees would spend half of their time.

It's just natural (to mix and mingle community support and commercial activities). It's like breathing. I will have a commercial meeting with one of my managers. I'll have someone in from Lion Breweries. And then I'll have St. John's in.

Greg Mulvey: interview 16 May 2005

The very fine facilities of Stadium Southland and the unique, yet simple, genius of the zero fees scheme at SIT owe their success primarily to two people - Ray Harper for the first and Penny Simmonds for the latter. It is doubtful that the Stadium would have eventuated (at least in its present form) without the leadership and strength of character over a number of years of Ray Harper. It is even more doubtful that the myriad of problems would have been solved and the $\$ 11$ million found without the management support and perseverance of the ILT. It is a story that deserves to be told in its entirety because of the lessons it provides and the contribution it has already made to Invercargill.

The zero fees scheme was born on Penny Simmonds' paper napkin over dinner on Stewart Island at a meeting of community leaders on recreation. Its logic was simple - increase course participants by funding through community support the tuition fees for a period of three years and once a certain mass of students had been reached, the increased Government subsidies would sustain the zero fees. ${ }^{309}$ The benefit to the City would be the increased economic activity of the extra students. It has achieved success well beyond

309 The major proportion of the $\$ 7.25$ million funding came from the Community Trust of Southland (\$3.452million) with ILT the next largest at \$1.726million. 
that envisioned: student numbers have increased from 1773 (EFTS) students in 2000 to just on 5000 today. But so also has the City's vitality increased. Infometrics Limited, an economic forecasting and analysis company, calculated in 2002 (when the roll had grown to 3376 EFTS) that the turnover of Invercargill businesses had increased by $\$ 25$ million, GDP by $\$ 13.9$ million (a return of 5:1 on the investment of community funds) and 266 fulltime jobs had been created as a direct result of the zero fees scheme. ${ }^{310}, 311$

\section{BOX 11}

People left (Invercargill) to do something better. There was that feeling you had to get out of the place to do something better. The change in mindset - the feel good factor - came from the zero fees scheme, Stadium Southland, the Southern Sting...

Penny Simmonds: Interview 16 May 2005.

The community support programme is well ordered and managed, fully integrated into the day to day work of the ILT, as the interview with its General Manager (see Box 10) indicates. Applications for donations must supply defined information, and follow defined processes and policies. The Board of Trustees gives some limited delegated authority to its senior managers but reserves to itself the bulk of the work and decision-making. What is significantly different from the majority of other similar philanthropy is the degree to which Trustees and management are involved in partnerships with the applicants to better ensure delivery and success of the community

\footnotetext{
310 Infometrics Consulting (2002), The Southland Times of 5 September 2002 and Prendergast (2004). It is beyond the scope of this study to debate the educational effectiveness of the scheme and its contribution to upskilling Southland.

311 While the critics of this scheme would insist there is more to education than economic value and that the quality of some educational aspirations may be of doubtful value more driven by the zero fees than achievement, the leaders of the scheme in Invercargill can point to a number of benefits additional to GDP, for example, local vitality. It is interesting to also make a comparison to Taranaki, a region of similar population to Southland. In Taranaki, their EFTS had risen in 2003 to just over 1900 students compared to SIT's of just on 4000, both rising from a similar base of students in 2000.
} 
support. Comparisons to two of the other case studies in this series, the West Auckland Licensing Trusts and the TSB, support this.

A further matter of note is the strength of the strategic ${ }^{312}$ linkage. The ILT has a clearer understanding and focus than most on the association between its business function and its community support role. While it may say with genuine belief that its role is to do everything it can to make Invercargill a better place to live, that must still be translated into day to day realities. If too much time is spent on philanthropy to the detriment of its business enterprise, profits become under pressure. There is clear commercial benefit in retaining more young people in the City. There is major economic benefit for a hospitality operator if more major events through Stadium Southland are brought to the area. The status of a first division rugby team brings commercial benefit. Less direct is contributing $\$ 1.5$ million to the construction of a new learners' swimming pool but here too the linkage with the ILT is prominently presented at the venue.

\section{COUNTER CASE}

Much of the evidence presented so far has been positive about, and supportive of, the ILT. That has been the natural flow from the interviews and the documents. ${ }^{313}$

The most common criticisms ${ }^{314}$ of the ILT would be:

- they are a monopoly;

\footnotetext{
312 Porter and Kramer (1999 and 2002) provide a good treatment of the strategic possibilities of philanthropy.

313 It is emphasised it is the natural flow. The interviewees were selected for their status and balance across sectors, that is, 3 are actively involved in ILT matters, a noted businessman (and community leader), the CEO of the largest educational institute, the Editor of the major daily newspaper, and the Mayor. A critic may say that some of these may have reason not to be critical of the ILT because of the support they receive or have received. But that criticism would denigrate their status and professionalism and overlook the importance of the documentary evidence.

314 As discerned from newspaper files, personal experience and the West Auckland case study in chapter 6. The latter, because of its confrontational nature and the resulting conflicts, is particularly insightful.
} 
- the lack of open market conditions keeps prices higher;

- private enterprise would bring a greater variety and richness of licensed premises;

- there is no evidence that the ILT does a better, more socially responsible job of managing sensitive products; and

- the gaming profits (which comprise the greater portion of the community support donations distributed by the ILT) would still be available for distribution in Invercargill even if the ILT did not exist or existed in an open, competitive environment.

The monopoly issue is multi-hued ${ }^{315}$ and is a topic of some magnitude. What follows is intended only to sketch its dimensions while addressing its key elements.

Most often, the monopoly accusation is based on the premise that inherently it must be bad. That is not necessarily true. Monopolies can have features that tend to abuse, for example, arrogance towards customers, a culture of excess and inadequate accountability mechanisms. But these do not automatically associate and in ILT's case, were rejected by the interviewees. Personal experience and observation reinforced that position. In any event, the community have in the competition poll legislation the ultimate ability to censure and control. ${ }^{316}$ That they have not invoked that must be a measure of some acceptance that the monopoly position that applies is preferred, on balance, to the alternative of open market competition. In other words, the benefits the community receive from the present state of affairs are perceived to be greater than the benefits they forego. All of those interviewed supported

\footnotetext{
315 The West Auckland case study explores these in more depth.

316 Further control mechanisms are agitation through the media and triennial elections.
} 
that on balance the present position was preferable for Invercargill. ${ }^{317} 318$

One other dimension is the degree of monopoly that exists in the ILT's fields of trading. Accommodation is a fully open market; clubs, both sporting and chartered, are licensed and are competitors to the ILT for the beverage, meals, gaming and social markets; and licensed restaurants and cafes frequent the city. While the General Manager of the ILT noted there were over 100 competing licensees in their geographic area, the ILT has monopoly advantages particularly in the off-sales area where supermarkets can not sell liquor and none other than the ILT ${ }^{319}$ operate bottlestores.

Supermarkets would bring a new and reduced level of pricing to take home liquor sales. ${ }^{320}$ In effect therefore, the community accepts higher prices and the lack of convenience of purchasing liquor with food as one price to pay for the other benefits they receive from the ILT.

An open, competitive marketplace appears to give flight to a greater variety of styles as people compete on individuality rather than size. With variety comes greater change of ownership and inconsistency of standards - the boom and bust' cycle of the competitive market place. Organisations like the ILT are often more able to provide consistency of management and standards but can also become (largely or somewhat) 'institutionalised' in their services and premises. ${ }^{321}$ The importance of variety is likely to be personal and have some correlation to age; for example, a younger person is more likely to prefer a larger premise and crowd whereas an older person may seek a quiet

317 Why this is so is a complex range of options that can vary for each resident and over time. The West Auckland case study canvases these issues in more depth.

318 Greg Mulvey stated that their polling research indicated that $70 \%$ of voters also agreed.

319 Chartered clubs can operate bottlestores for their members.

320 The evidence for this is in the level of pricing that exists where supermarkets trade in open competition with bottlestores (specialty liquor merchants), and in the market share they enjoy (in excess of $40 \%$ ).

321 This was mentioned, not as a criticism, by two interviewees. The quality of ILT premises is exceptionally good, from the Ascot Park Hotel with its $100+$ rooms (soon to be 130+), to its 8 restaurants. For a complete list of premises see www.ilt.co.nz. 
restaurant. Preference will vary over time and because of circumstance. Thus, there can be no one answer, acceptable to all, to any allegation that the variety and quality of premises the ILT provide is limited.

The sensitive products issue lacks sufficient statistical data on which to make compelling judgements on whether the ILT manages the sale of alcohol and the provision of gaming services better than competitors and providers in other areas. This is unfortunate in the context of the historical concern that was one of the substantial justifications for the formation of the ILT: to sell alcohol with care. It may not be quite the community concern it was in 1944, but it is, particularly when combined with gaming abuse, still an issue of some consequence. Greg Mulvey and Ray Harper did provide stories of their immediate reaction to community concerns expressed to them but while reinforcing the effectiveness of community accountability, the stories reflect incidences of isolation. Nonetheless, it is reasonable to accept the premise that as a community enterprise committed to the well-being of its community and not to maximising profits, the ILT has more reason than most to lessen alcohol and gaming abuse.

Gaming machines per head of population provide a measure of availability and thus may indicate how actively gaming revenue and profits are being pursued. Comparisons between six cities ${ }^{322}$ placed Invercargill mid-field. ${ }^{323}$ Thus, the conclusion can be reached that the ILT has met market demand but unlike the West Auckland Trusts ${ }^{324}$ has not underprovided or restricted availability.

\footnotetext{
322 Invercargill (143 people per machine), Nelson (123), Palmerston North (151), Napier (130), New Plymouth (163) and Waitakere (341). Population figures were taken from the www.stats.govt.nz website and gaming machines from the Department of Internal Affairs web-site www.dia.govt.nz Gambling Watch (see www.gamblingwatch.org.nz ) places them $38^{\text {th }}$ of the 74 local authority districts with 1 machine per 108 adult residents compared to the New Zealand average of 1 per 118 residents.

${ }^{223}$ ILT are not the sole provider of gaming machines in Invercargill City (they operate 199 machines out of a total of 348 as at 31 March 2005) and thus their policies are not the sole influence on the availability of machines.

${ }^{324}$ See case study in chapter 6.
} 
The last of the listed criticisms - that the majority of the community support provided by the ILT is generated from gaming profits that must by law be distributed to the community - is factually correct. ${ }^{325}$ The criticism implies the ILT presents a better 'face' to its performance than is justified.

As the West Auckland Trusts case study concluded, that fine distinction appears to be of limited importance to the community. The perceptions that other distributors of gaming profits tend to skew donations to sporting organisations (particularly those that trade with the pub that operates the gaming machines) and retain a greater portion of the profits through site rentals $^{326}$ continue to abound, although recent changes to legislation ${ }^{327}$ and regulations may over time better address the irregularities that have occurred. Gaming profits, like other fields of business enterprise, require investment and good management. They are thus accepted by the majority as 'belonging' to the premise that creates them.

\section{CONCLUSION}

How would a jury of citizens pass judgement on Member of Parliament Archer's prediction over 60 years on?

The ILT is a thriving enterprise providing very fine services and facilities to its customers, and generating very good returns for its owners, the people of Invercargill. Its leadership role in the city is dynamic. The community support dividend envisioned under the Invercargill Licensing Trust Act 1944 has produced, and supports, some outstanding regional facilities, so much so the community can justifiably say they are very well served for a city their size.

\footnotetext{
325 Of the $\$ 6.748$ million (2003, $\$ 5.231$ million) donated to the community in 2004 , $\$ 4.681$ million (2003, $\$ 3.492$ million) came from gaming profits.

326 The operator of the gaming machines is entitled to claim costs of operating termed site rentals. Cases of substantial weekly rentals well above the present regulated level of $\$ 140$ per week were common. Site rentals often bore a close relationship to the minimum level of payout insisted upon by the Department of Internal Affairs (33\%). The ILT has consistently distributed in excess of $50 \%$ of revenue.

327 Gambling Act 2003.
} 
Stories were told to me of international visitors who expressed amazement and envy at the ILT model. It may be a little too much to say the ILT has enhanced the reputation of New Zealand thronghout the world but there would be few in Invercargill who are not more than a little proud of their Trust. 


\section{CROSS CASE ANALYSIS}

What follows in this chapter is the analysis and cross case conclusions component shown in figure 4.2.

As Yin (2003) and figure 4.2 highlight, the cross case analysis must be benchmarked against the preliminary framework that arises from the review of literature in chapter 2. That review generated a four component schematic that, in the nature of a schematic, simplifies and summarises the characteristics of community enterprises:

\section{FIGURE 9.1}

\section{COMMUNITY ENTERPRISES SCHEMATIC}

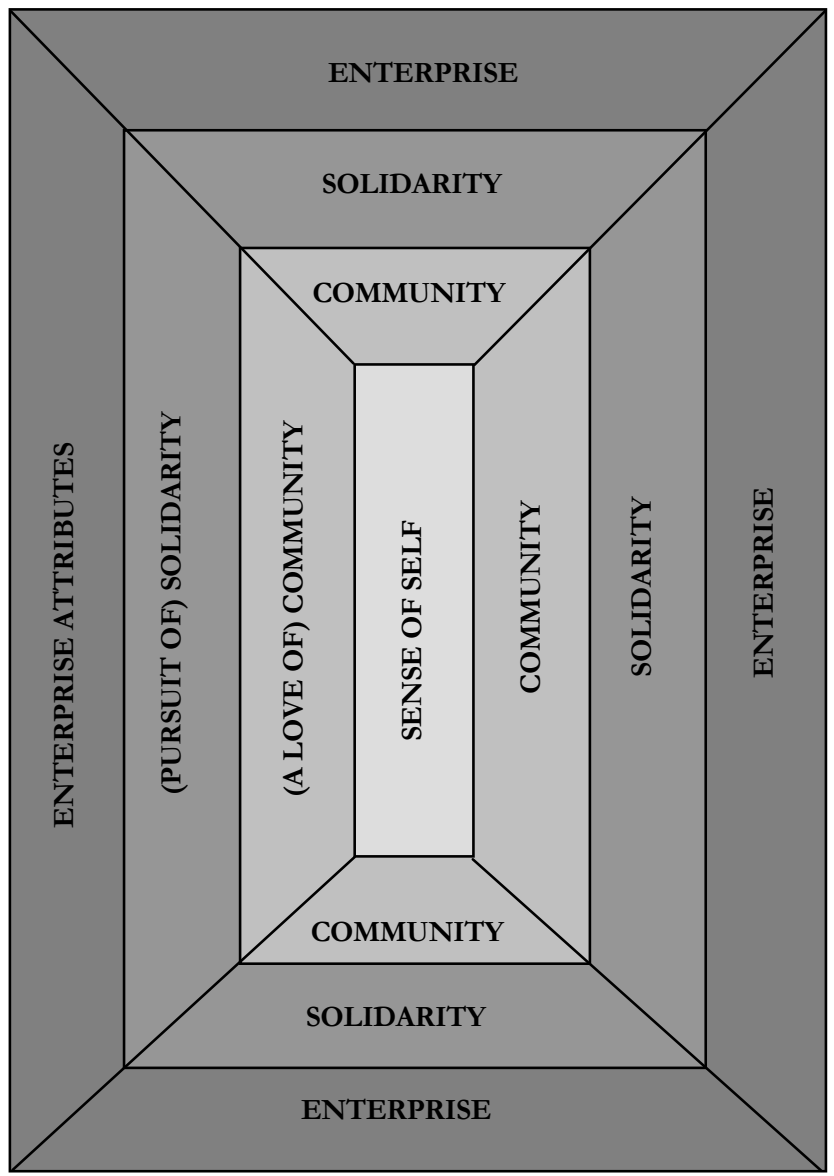


As noted in the concluding summary of chapter 2, each of the four concentric components has underlying shades of meaning. For the cross case analysis to be effective and searching, the concentric headings need to be further dissected. To not do so, would lose these significant hues. The discursive analysis which follows therefore, takes the form of comparing these constituent parts (as first presented in Table 2.1 as arising from practical observation and the literature search in chapter 2 and now repeated here) for relevance and presence in the four field studies:

TABLE 9.1

CONSTITUENT PARTS OF COMMUNITY ENTERPRISES

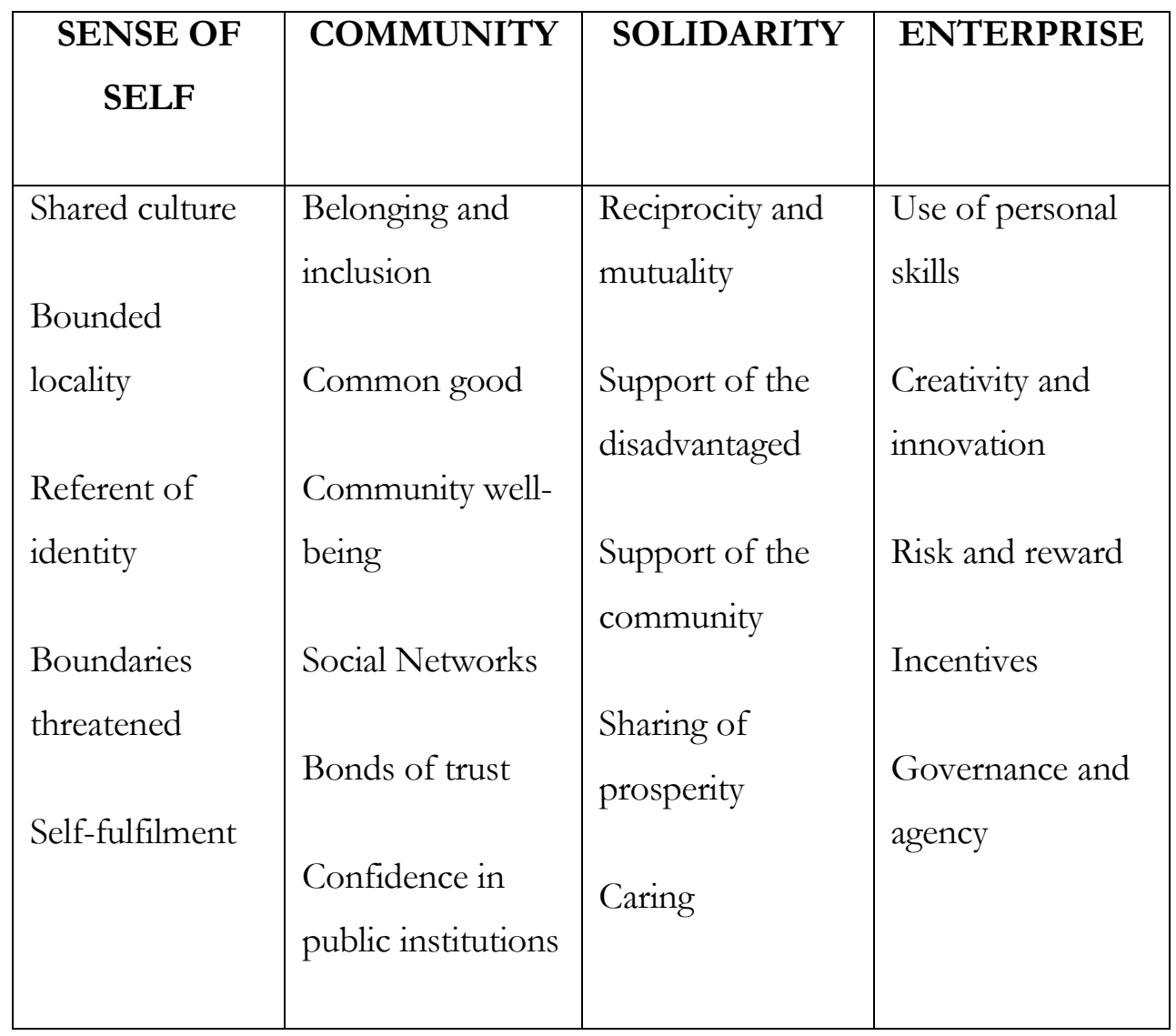


Each term is defined in its sectional analysis. For some, the distinction from their neighbours is blurred. For others, it is distinct. The blurring of separateness, while acknowledged as a distraction, is justified on the shading of analysis that the characteristic by its inclusion provides. At issue here is the desire to achieve a searching analysis. Such is the nuanced nature of community enterprises that it will not be captured by broad and encompassing headings.

Finally, in this chapter, the discursive analysis is extended into the contentious issues listed and described in chapter 2.

\subsection{SENSE OF SELF}

The pivotal inner core of community enterprises is the individual. Cohen's (1985:117) words which are the foundation of the explanations in section 2.2.1 are worthy of repetition: '...the survival, the burgeoning, the assertion of community (is) not...an aberration to be explained, but ...a normal, expectable expression of the resilience of culture: of people's sense of self.' But a 'sense of self' is more than a fear of something lost as evidenced by the vignette in section

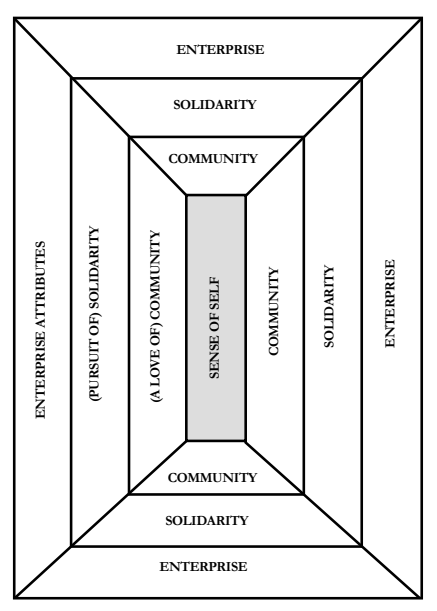

2.2.1 of the long serving members. To attempt to capture, therefore, the nuances of this inner core, analysis will follow under five component parts:

- Shared Culture

- Bounded Locality

- Referent of Identity

- Boundaries Threatened

- Self Fulfilment. 


\subsubsection{SHARED CULTURE}

Shared culture may be defined as the belonging to a social group that has a common cultural tradition. Culture, like ethnicity, is a much written subject, and open to significant contentiousness. It can have a number of meanings but for the context of this study the Oxford Dictionary's description satisfies: 'of or relating to the ideas, customs and social behaviour of a society.' Nationality, for example, being a New Zealander, would represent a categorisation and definition but that is likely to encompass a wide variety of sub groups; for example, of Scandinavian ancestry, or a region, a Southlander. A sub group emphasis may receive greater or less prominence at different times. Regional pride may achieve importance on the occasion of a major sporting event. Ancestry may be clung to for nostalgic or defining reasons: 'it is what I am, my cultural tradition' and may be expressed on important anniversaries. These are value-laden subjects open to much debate and prone to vigorous defence as sadly witnessed by the ethnic conflicts and genocide prevalent in parts of the world. Cohen's (1985) words at the beginning of section 2.2.1 well summarise their multi-faceted nature: we assert our ethnicity or community when we see in it 'the most adequate medium for the expression of (our) whole selves.'

But while Cohen (1985) helps to understand why some groups or communities react strongly to challenge - because their personal sense of self is under threat - it is more difficult to explain why some communities react strongly to a challenge and others do not. Because ethnicity and culture are multi-faceted, it is often difficult to detect which facet dominates in each instance.

Thus, an answer to the question 'to what extent did a shared culture matter in the four studies?' can only be partial. It is doubtful that anyone, participant or observer, does know the answer. When asked what comprises and generates the spirit of Eketahuna (a 'Westie', Taranaki or Southlander) the common answer was 'I don't really know.' But this lack of definition does not negate its 
presence.

In Eketahuna, Peter Best's (2001) 'The pioneering spirit is still strong in our community. We are a people of determination and achievement. We are not afraid to go it alone and get it done' gives a lead to the spirit of that community. The common Scandinavian ancestry and tradition of hard work breaking in a rugged land may also contribute.

'There's something special about people who have lived in West Auckland - a spirit of freedom and independence' (Harvey, 2004). His lyrical description of a Westie: 'enthusiasm, creativity, tolerance and a 'can do' attitude mark out the true Westie' has undoubtedly a large element of his passionate approach therein. But his quotes from Warwick Roger (1989) whom he credits with writing the definitive article on West Auckland, helps bring the spirit of a Westie a little clearer: 'a complex but positive community, people determined to do better, to struggle and to achieve for their children and the wider community.' While that description could be a generic aspiration of a number of communities, Harvey's snapshots of the West's characters paint a picture of freshness, difference and 'can do'.

Taranaki and Southland are both regions noted for their spirit of independence, Best's going it alone and getting it done. Perhaps a small but distinct isolation helps to create that spirit.

The partial, incomplete answer above leaves an uncertainty as to the extent a common cultural tradition is a factor in the formation and ongoing success of the four community enterprise studied. Greater certainty would require a concentration on the ethnicity and culture of each of the four areas than is warranted for this study. Thus the nuance of this component may have to rest with an answer that is more 'felt' than fact: a common cultural tradition was a factor in each of the four studies. But the degree of importance and its nature is largely unanswered. ${ }^{328}$

328 It is acknowledged that this discussion on the influence of culture is quite limited. The author defends this limited treatment on three grounds: the subject's complexity; a shared culture is but one 


\subsubsection{BOUNDED LOCALITY}

Each of the six community enterprises in the four studies have a defined geographic area: Eketahuna is defined in its Trust Deed; the West Auckland Trusts by gazette on their formation; the TSB Community Trust's original definition of area is maintained by inclusion in the Community Trusts Act of 1999; and the ILT area was originally defined in Invercargill Licensing Act of 1944 and maintained by the Sale of Liquor Act of 1989. While these definitions provide certainty of land boundaries, less defined but perhaps no less certain are those perceived and felt. People relate to an area because it is 'felt' to be home. What generates that feeling is a complex and personal combination of family, friends, work (occupation), history and values. Cohen (1985:118) argues that though the structural boundaries of community may be undermined (for example, by globalisation's homogenising effect), peoples' perception of community will be defended if it is valued. Thus while a community is most likely to have originated through geographic definition, it is not necessarily essential for continuance. In all four cases, however, the geographic boundary definition is strong.

A strong and striking feature of all four studies is their strong community spirit that is linked to a defined geographic region. Being from Eketahuna, a 'Westie', Taranaki or a Southlander significantly defines. You do not have to come from these regions to know that the bounded locality is a defining characteristic.

Examples abound. The Eketahuna reaction to the possibility of losing their representation on the Tararua District Council was notably stronger than nearby Pahiatua; the focus group's response in West Auckland - 'we are different' (from the rest of Auckland); Taranaki's 'going it alone' of the 12 Trustee Savings Banks; and Southland's separateness is a factor in Invercargill

component influencing the existence of community enterprises; and to answer in depth would require a study of some magnitude. 
being the only area, able to do so, in which a competition poll has not been contested.

\subsubsection{REFERENT OF IDENTITY}

The symbolic construction of community occurs because it is a meaningful resource to which members can personally relate. In effect, as Cohen (1985:118) argues, it becomes 'theirs'. Therefore, it will be personally defended with the vigour of the defence bearing a direct relationship to its importance to the community, both on an individual and collective basis. A striking example of how personal such issues can become is in community health resources. A number of years ago (circa late 1990s) the author attended a public meeting in Masterton on possible impacts on health resources in the Wairarapa where a common perception was the closure of hospital(s). The vehemence (no exaggeration!) of the attacks on officials was startling. The 22,000 people who turned out (see note 51) to circle these hospitals again reflects the emotions of those times.

The four studies had similar themes: the community enterprises were valued. Individually it varied, and over time and for circumstance. But collectively the four studies showed there was a high regard for the six enterprises.

In Eketahuna the collective response may be seen in the attendance at the two public meetings and the amounts the community were prepared to lend on debenture, and for some not to seek repayment. It is represented too in their support of the business enterprises. For the supermarket, usage by the community was better than $30 \%$ higher than for a comparable unit. In West Auckland, the poll results are a vote in support even though that support is, arguably, a subsidy by the community. The Taranaki community accepted that their bank should go it alone and never seriously debated the alternatives as indicated by the paucity of comment, let alone opposition, in the media at the time. And in Invercargill the lack of any challenge by the supermarket chains 
which have considerable financial incentive to do so, represents an awareness that such a poll has little chance of success.

'Referent of their identity' can, and often will be, a selfish exercise judged on the personal benefit the community enterprise provides. Why the health response in Masterton was so extreme was the personal fear of loss of services perceived to be essential: in effect, 'my health will suffer if those services that have always been there now disappear'. It may make little difference that the alternatives may be better or at least have the potential to be so; or that what is there now may be unsatisfactory. The unknown often generates a significant distrust. In Eketahuna, the supermarket and service station are considered to be essential to individual needs. But while 'selfish' needs are important, there is also a factor of pride. The lack of a supermarket and fuel station lessens the status of their town. In West Auckland and Invercargill the fear that the extensive community support the three trusts provide may be lost generates a protective screen. As one interviewee said in Invercargill, there are few people in the city who are not touched in some way by the support of the ILT. In these circumstances, it is easy to make a personal connection.

But it would be wrong to infer that selfishness - 'what's in it for me' - is all, or mostly all, there is to this component. Cohen's final words (:118) 'People construct community symbolically, making it a resource and repository of meaning, and a referent of their identity' have a deeper layer than personal reward. There are overtones of what Jensen and Meckling (1994) argue: '(People) care about not only money, but almost everything - respect, honor, power, love, and the welfare of others.' The success of the community enterprises becomes personal success. People tell stories about them, stories told with pride. Thus the TSB Bank is spoken about with pride, even affection. It is hard to define precisely why this should be so. It is after all only a bank. A good bank, yes, that looks after its customers well and distributes a portion (smaller than most) of its profit to the community. 
Why the pride and affection is present will always be hard to define for it is unlikely to be due solely to any one factor. There becomes almost a spiritual component that those who attempt to define community will (almost) inevitably come up against - a deep chasm that may require a leap of faith to understand. ${ }^{329}$ Fowler's words (1991:4) can now be placed in better perspective: 'Community goes deep into our souls, and in the process helps us to understand ourselves in quite (but far from exclusively) rational terms.'

It would be wrong too, to infer that the personal identification with the community enterprises is all and always positive. Because it is personal there will be times of disagreement and conflict. While the majority of West Aucklanders support their Trusts, it is as well to remember that at the last poll $42 \%$ disagreed with the exclusivity of licences, some very strongly and stridently so. Amongst the interviewees in Taranaki there were murmurings of discontent. The ILT, not that many years ago, had been the subject of derision. The distrust and dislike that can arise when things go wrong and disappointment turns almost to hatred is well evidenced by the vehemence of the community and media's attacks on the five Wellington Licensing Trusts that failed in the late 1990 s and early 2000s. ${ }^{330}$

\subsubsection{BOUNDARIES THREATENED}

Cohen's $(1985: 45,50,69)$ tells us that awareness of community and culture occurs at the boundaries ${ }^{331}$ and when these geo-social boundaries are threatened, determination of their importance then occurs. The more they are valued, when related to the significance of the threat, the greater is likely to be the community's reaction.

\footnotetext{
${ }^{329}$ Henri Nouwen (1976) offers a further insight: 'Ideas of value always shun verbosity, being foreign to confusion and fantasy.'

330 See, for example, Evening Post editorials and articles of 27.11.1996, 12.3.1997, 23.1.1998 and 27.3.1999.

331 Cohen's (1985:69) fuller explanation: '...people become aware of their culture when they stand at its boundaries: when they encounter other cultures, or when they become aware of other ways of doing things, or merely of contradictions to
} 
Eketahuna's almost total community mobilisation to address the loss of essential services reflected their perception of the threat to the way of life they valued. In West Auckland a number of challenges occurred. When the supermarkets advertised in their campaign that elsewhere throughout New Zealand people could buy liquor in supermarkets and why should West Auckland be different, they were ironically helping the Trusts. 'Westies' believe they are different from the rest of Auckland and have been encouraged to do so by writers such as Roger (1989) and Harvey (2004). Thus in supposedly seeking to provide benefits they were attacking the boundaries of the very people they were seeking to benefit, boundaries that were valued. They attacked also other sensitivities. Concern over gaming and, to a lesser extent, alcohol abuse, led activists concerned over these issues to be threatened by a greater freedom of license. But the most significant threat appeared to be the perception that the greatly enjoyed community support programmes and the personal household gifts were at risk.

For the TSB and the ILT the attacks at the boundaries are more benign. Here the threats, while to varying degrees expressed (the TSB may be sold to private interests, the ILT may be subject to a competition poll), remain more in the background. Nonetheless, they can be sensed to be real. In Invercargill, the former President of the ILT, Ray Harper, believes the threat of a poll to be beneficial. They must always, he states, question whether their standards and their support for the community are measuring up to expectations of the community. ${ }^{332}$

Boundary threats, therefore, are often discernibly beneficial. They may not appear so at the time but the challenge faced and overcome has the potential to strengthen bonds and processes. If not overcome, then it is legitimate to

their own culture. The norm is the boundary: its reversal, a symbolic means of recognizing and stating it... Such awareness is a necessary precondition for the valuing of culture and community.'

332 Interview 10 March 2003. 
ask whether the organisation was valued enough. Alternatively, it may be that the forces for change were too powerful.

\subsubsection{SELF-FULFILMENT}

There was a dilemma in choosing the title of this component. As the discussion in section 2.2.1 suggests, there was a range of choice: Maslow's self-actualization, James' spiritual, Gewirth's self-fulfilment and even Cohen's sense of self as a sub-group of its own. There are a number of linkages to other component parts, for example, a sense of belonging and inclusion that is predicated on the premise that we strengthen ourselves when we strengthen community association; and people's sense of self is linked to their personal self-fulfilment, the personal skills component. But it is Cohen's words (1985:114) that again provide the substantive theme of this sub-section: 'Our argument has been, similarly, that community is largely in the mind. As a mental construct, it condenses symbolically, and adeptly, its bearers' social theories of similarity and difference. It becomes an eloquent and collective emblem of their social selves.'

'An elegant and collective emblem of their social selves' is harder to discern from the four cases because it is so personal. We are left therefore with snapshots.

Ray Harper's (ILT) 'there must be a bit of the socialist in me ${ }^{, 333}$ and Penny Simmonds' musings that he (Harper) may have been elected to the ILT Board because the electors thought it needed strong leadership ${ }^{334}$ give insights. Margaret Parsons' (ECCT) 'we can do that' ${ }^{335}$ response to a Dominion newspaper article on a community store was 'merely' the instinctive and inevitable response in a life-long commitment to enhance the Eketahuna community, a commitment no less strong than John Harman's (the Chairman of the ECCT). His extensive volunteer hours over 18years to make the

\footnotetext{
333 Interview 10 March 2003.

334 Interview 16 May 2005.

335 Interview 4 September 2003.
} 
supermarket and service station work for both the operators and the community suggest something deeper than a sense of duty. Greg Mulvey said that he would not work the hours he did were it not for the community nature of the ILT. ${ }^{336}$ There were strong personalities also deeply committed at the TSB Bank and the West Auckland Trusts. But circumstances did not allow for more in depth questioning on whether the dedication was that of leaders committed to excellence or whether there was some factor generated by the nature of community enterprises. And the final insights come from the vignette on the long serving members (see section 2.2.). Both members sought to meet personal aspirations.

\subsubsection{CONCLUSION}

The analysis and answers that arise when the five component parts suggested by the literature reviewed in chapter 2 (section 2.2.1) are compared to the four field studies are frustratingly incomplete. But they will always be so. A sense of self is so personal, so fluid and so little discussed and defined that people find it difficult to express, as those interviewed did, what makes their community special: to answer what is their special spirit? Instead we are left with a range of factors and snapshots that contribute in varying importance over time and circumstance.

336 Interview 16 May 2005. 


\subsection{COMMUNITY}

The literature discussion in section 2.2 .2 suggested six components:

- Belonging and Inclusion

- The Common Good

- Community Well-being

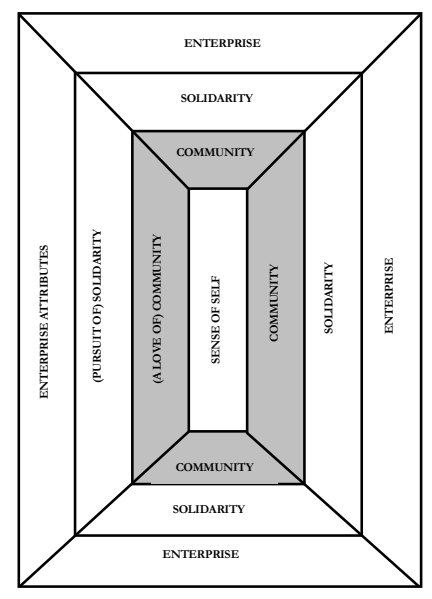

- Social Networks

- Bonds of Trust

- Confidence in Public Institutions.

\subsubsection{BELONGING AND INCLUSION}

A sense of belonging and inclusion logically offer meaning and purpose, and the lessening of conflict. 'Our most intimate social networks, especially family and friends' generate 'our deepest sense of belonging' (Putnam, 2000:274). Local community groups and organisations are also important contributors. ${ }^{337}$ In what ways, therefore, do the organisations in the four case studies contribute to a sense of belonging and inclusion in their communities?

The community debentures at Eketahuna are a longer term contract between the individual and the collective community. The results of their contributions (that is, the supermarket and the service station) are prominent on the main street and available for use every day. They are a daily reminder of their collective response to the loss of essential services.

In West Auckland the regular media stories on the Trusts' philanthropic decisions and the grants to many community organisations remind residents

337 Putnam's (2000:275) figure 77 gives weightings to the various ways a real sense of belonging is achieved. 
of the wisdom of their vote, if they believe it to be so. The lack of beer and wine sales in supermarkets does the opposite and will be a continuing source of conflict (of exclusion for some) until solved. Notably, the Trusts' market research indicates that significant sections of the community believe not enough information is provided on their activities suggesting that constant reinforcement and reassurance is required. ${ }^{338}$ Inclusion is also available every three years at the elections of Trustees and while critics may say this is a remote and nebulous vehicle, the ability to select their representatives is a powerful symbol of ownership.

For the TSB Community Trust the symbols of belonging and inclusion are slightly more remote than the West Auckland Trusts. The Bank's branches, sponsorship with naming rights, philanthropy and media releases/articles (100 over 20 months) provide linkages but there are no elections of Trustees. The feeling of pride in the Bank is curiously strong; curiously, because it is difficult to define precisely why it occurs. Part of the answer may lie in the remote ownership of the other banks. Remarkable performance would also contribute.

The ILT provides similar vehicles to West Auckland but with a notable increase in intensity and extensiveness as befits a very prominent and influential organisation.

These linkages between the individual and the community enterprise will only rarely be as strong as the bonds of family and friends. Rather they must be seen in the context of contributing to a strengthening of the community's social fabric.

\subsubsection{THE COMMON GOOD}

The notion of the common good was defined in the Papal Constitution of Paul VI's Gaudium et Spes (1965:74) as the sum of those conditions of the social life

338 Source: UMR research, reports of various dates. 
whereby men, families and associations more adequately and readily may attain their own perfection.' There thus appears to be an inherent tension between the individual's freedom to choose their path and the collective good. ${ }^{339}$ Epstein (1998:5) reconciles that tension this way: 'So what we do is develop a social contract. We impose upon all individuals duties which work to their reciprocal benefits, in the expectation, given what we know about human psychology, that they will be better off with the restraints than they were with the liberties that they surrendered in order to attain them.'

The question for this study to address is in what ways did the community enterprises address the common good of their communities?

In Eketahuna, the citizens' loans without interest allowed the ECCT to build the supermarket and the service station and rent them out at subsidised rates to operators who thus would be better placed to earn a satisfactory return. The individual thus accepted that their initial sacrifice would provide a greater good which may, or may not depending on individual circumstances, also benefit them personally. ${ }^{340}$ Thus a personal good was intertwined with the common good, well exampling Epstein's contention.

The concept of Licensing Trusts is premised on the common good. The basic idea behind these Trusts is that sensitive products like alcohol and gambling should not be treated as normal commodities available for sale without restraint and subject only to the rules of the marketplace. Trusts were originally given the mandate to sell alcohol with care. Implicit in this is moderation of use. There was clear evidence that the West Auckland Trusts restricted the number of gaming machines in their areas. Less clear was the position on alcohol. A supporter of Licensing Trusts could argue that the unavailability of alcohol in supermarkets and the restriction on access to licences under the competition provisions of the Sale of Liquor Act lessened alcohol sales in the Waitakere, Portage and Invercargill areas. But a critic

\footnotetext{
${ }^{339}$ For a treatment of some of these tensions see note 36.

${ }^{340}$ For an explanation of this reasoning see chapter 5.
} 
could argue that the Trusts' motivation to do so was more competition driven than the good of their community. However, the community's acceptance of these competition restrictions is itself an example of the common good. The community perceives it benefits more by the restrictions.

The TSB Community Trust's acceptance of a smaller dividend from the Bank so as to allow the Bank to grow has achieved that goal and also significantly increased its net worth. But these benefits must be offset against the loss to the community of increased philanthropy. This example of the individual good suspended now for the greater good later reflects a different emphasis of the common good concept.

\subsubsection{COMMUNITY WELL-BEING}

This concept, (a legislated example is the 1947 Masterton Licensing Trust Act which required that Trust to provide their services in the interests of the public's well-being), has arguably achieved greater prominence in recent times as regions and nations compile measures that attempt to judge the quality of community life. Significant sophistication and complexity is reflected in such indexes; for example, the Well-Being of Nations (Prescott-Allen, 2001) gives 36 indicators of health, population, wealth, education, communication, freedom, peace, crime etc for 180 countries in their human well-being index, and 51 indicators in their ecosystem well-being index. This section has more modest aspirations in seeking to list the ways the four studies observed how the community enterprises contributed to the well-being of their communities.

Apart from the previously recorded provision of essential services, the Eketahuna study's notable feature was the enthusiasm and vitality it generated in the community, and a recognition of their ability to achieve more. Their successes are well profiled in main street activity today much increased from the turn of the millennium. 
Philanthropy is a common feature of all four studies, and the community support provided at both a major and minor level in West Auckland, Taranaki and Invercargill is notable. A common feature of the interviews was assertions that without this support, a number of projects would not have happened. Stadium Southland is a case in point.

The sensitive products moderation listed in the previous section and the mandate originally given to Licensing Trusts reflect an emphasis to well-being in West Auckland and Invercargill. Regrettably, in the absence of well-being indexes, for example on alcohol, crime and gambling abuse, there is no known measurement of its effectiveness. Instead, we are left with the anecdotal stories in the studies.

The West Auckland, Invercargill, and in a smaller way Eketahuna's commitment to education are notable both in the quantum of financial support and, particularly in Invercargill, their dedication to raising standards.

But in the end, the most notable feature of the community enterprises is their nature. They have a commitment to their communities that words, and indexes were they available, can only pay small service. It is what they are, their reason for being.

\subsubsection{SOCIAL NETWORKS}

For most of us, our deepest sense of belonging is to our most intimate social networks, especially family and friends. Beyond that perimeter lie work, church, neighborhood, civic life and the assortment of other "weake ties" that contribute our personal stock of social capital' (Putnam, 2000:274).

Eketahuna often operates like an extended family. In small communities people seem to know each other (Peter Best's village ${ }^{341}$ ) and while gossip and knowledge, assumed or real, can have an unhealthy component, involvement

${ }^{341}$ Refer the case study in chapter 5. 
in meaningful projects give purpose and substance to a community's life. It's as if the community becomes bigger because of it. It grows in pride and stature. The meetings in their houses to discuss and bring to fruition, the phone conversations and the discussions in Main Street (as witnessed by the newspaper photos and personal observation) all contribute to a richness of networking that leaves an ongoing legacy. This legacy has weakened over time as the projects' intensity reduced but is quickly available to be mobilised as other issues arise, for example, the Tararua District Council representation conflict.

In West Auckland, the Trusts' support for all the community organisations recorded on their annual donations list better ensures the survival of these groups that themselves add to the colour and density of community life. To survive, the two Trusts had to learn to work together, firstly through common management, and then to cooperate on major projects within Waitakere. The new stadium which takes the Trusts' name is one example.

The TSB Community Trust also gives emphasis to supporting a myriad of community organisations. While the donation is one aspect, arguably a more important aspect is the listening ear and 'shoulder to lean on' occasionally glimpsed in the photos of the Chairman, Trustee or Secretary attending and supporting a community event.

The ILT is intimately involved in its community. The theme of the interviews was 'there is little that publicly goes on in this community in which the ILT is not involved.' They too list a great number of clubs and organisations in their donations. They seek to network as exampled by their chairmanship of Stadium Southland, and the Education sub-committee that regularly decides on grant support. The availability of the General Manager and the President to meet and attend are other examples how community life is enriched. Ray Harper's 'three nights a week meeting with and speaking to community groups' is a deeper commitment than most other equivalent organisations. 


\subsubsection{BONDS OF TRUST}

Fukuyama's thesis (1995:7) that '... a nation's well-being, as well as its ability to compete, is conditioned by a single, pervasive cultural characteristic: the level of trust inherent in society' is reinforced by his quotation from Nobel laureate Kenneth Arrow (:151): 'Trust is an important lubricant of a social system. It is extremely efficient; it saves a lot of trouble to have a fair degree of reliance on other people's word.' There are many aspects that contribute to trust: for example, reliability, truthfulness, ability, strength of character, responsibility, duty, confidence and commitment. Two notable features stood out in the four studies: firstly, believable and reliable leaders who exhibited strength of purpose and confidence; and secondly, the activities of the community enterprises that increased the wealth 'bank' of trust in the community through shared commitment.

Through all four studies strong and respected leadership was apparent, and frequently dominant. There are, of course, degrees of leadership which vary over time and circumstance. In Eketahuna it has been consistently present for at least the period of the study, over 18years. It is not the 'larger than life' category but a persistence and consistency from a small group. In West Auckland there are strong personalities, some of whom are politically inspired. Personal political agendas can contribute to a patchy performance and this has occurred at times for the two Trusts, not solely through political conflicts. But in latter years the leadership, particularly from the General Manager, has been strong and able to generate trust. At the TSB Bank the long term leadership has been remarkably strong and constant while the Community Trust has been subject to political change which arguably has diminished the ability of their community leaders to perform. The ILT has very strong personalities, well respected in the community.

The second notable feature has been the activities of the community enterprises that have touched and involved so many within their communities. This 'shared commitment' is well illustrated by the number of 
donations for community support collectively that they make. Some 2500 organisations in these communities receive cash support, varying from a few hundreds dollars to hundreds of thousands of dollars. It would be strange indeed if this activity did not generate goodwill and trust, and so it is so. This trust, pride or respect, in whatever form it is manifested, was frequently stated during conversations in these communities, recorded in local newspapers and evident in well attended community grants meetings.

Shared participation and commitment also comes from the trading activities in which the enterprises are involved. The TSB Bank's and ILT's extensive trading activities, often facilities of some excellence, also create pride and generate trust and confidence, as illustrated in the interviews and by their success.

Strength and confidence also comes from success. All six community enterprises were notable for their good to outstanding performance when viewed over a long period of time.

\subsubsection{CONFIDENCE IN PUBLIC INSTITUTIONS}

The fall off in both confidence and participation in public institutions is well documented by Putnam (2000). His plea, recorded at the beginning of chapter 2, is for a renewal and reinvigoration of public institutions. Laville's (1999, 2000, 2003) and Salamon's (2003) description of the rise of third sector organisations recorded in chapter 3, suggests this is occurring worldwide. Whether this is occurring in New Zealand is difficult to discern. Unlike the United Kingdom and Europe there is no Governmental encouragement and support for social and community enterprises. It may be that there is some (private) community ${ }^{342}$ activity under the structure of charitable trusts but anecdotal information suggests there is no greater growth this decade than the

\footnotetext{
342 For example, in the nature of an Eketahuna Community Charitable Trust. The charitable trusts legislation is used for a wide variety of purposes including many that are personal, for example, a (non) taxation vehicle or for philanthropy.
} 
last. In the absence of reliable data we are left with the unsatisfactory position that while we can say that the climate has changed as reflected in the privatisation movement ${ }^{343}$, there is no evidence supporting the climate of growth that Salamon's (2003) study reveals.

The community enterprises that are the subject of this study are all respected in their communities. The support of almost the whole Eketahuna community is illustrated in the debentures and the greater sales per head of population in the supermarket. The polls in West Auckland are a vote of support, even if that may never be taken for granted. Minority opposition is strong and determined, as the newspaper editorials quoted in chapter 6 record. The TSB Bank is almost iconic (some would say it is). Support and respect for the ILT seemed to be everywhere in Invercargill as witnessed by the Mayor's and the local editor's comments.

Notably, the rise and renewal of confidence in these community enterprises is of recent times. The ECCT is 18 years old; West Auckland's performance and status improved during the mid to late 1990s; the TSB Bank's meteoric rise has occurred over the last 15 years; and the increase in the ILT's status is in the same period. This may suggest that a climate of acceptance and support may be a factor for not all the success can be placed at the door of good business cycles. ${ }^{344}$

\subsubsection{CONCLUSION}

The community components were particularly strong and notable in all four case studies. Of the six community enterprises only the TSB Bank with their emphasis on New Zealand ownership did not exhibit overt community

\footnotetext{
343 That is, that the present Government in New Zealand does not support further privatisation of state assets. Their position on community enterprises is less clear. A number of senior politicians have spoken in support of community enterprises (for example, the Prime Minister on the Invercargill Licensing Trust, and MPs during the public meeting in West Auckland - see chapter 6) but that is some steps removed from a supportive Government policy.

${ }^{344}$ Rural communities in particular have gone through some (relatively) hard times during the majority of the last 15 years. It is only in recent years that their economies have been buoyant.
} 
linkages. The other five regularly exhibited recognition that community ownership was their most significant point of difference when compared to equivalent private enterprise organisations. Thus, both from a marketing (business) and community support perspective they clearly saw there was advantage in identifying their uniqueness. This finding mirrors that of a Licensing Trust study in 1990 (Teahan, 1990).

\subsection{SOLIDARITY}

Solidarity, more extensively discussed and defined in chapters 2 and 3 , is the mutual support that exists within a group or community, or more simply, the caring for others. Gewirth (1996) states there should exist a mutuality between a person's right to freedom and well-being, and their duties to others. The effect of his contention is that

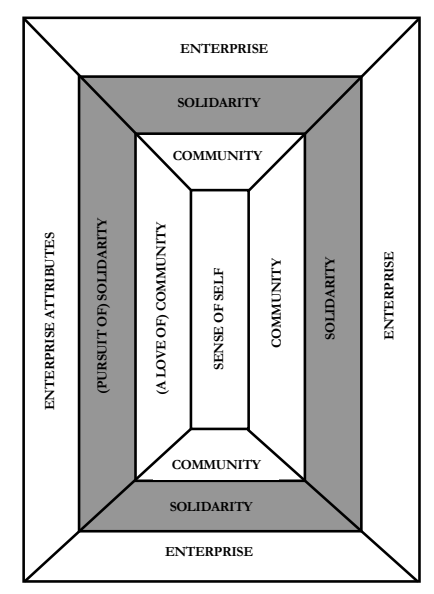
prosperity should be shared thus contributing, as Laville (2003) asserts, to justice and equality, and thereby assisting social cohesion.

The debates and disagreements that solidarity creates are more around its practice, or perhaps more definitively, the lack of it. In a more materialistic and individualistic world there exists many arguments that weaken or seek to weaken the principle from 'the individual should take responsibility for their status' to 'much of support blurs individual responsibility, is wasteful and ineffective.' Mario M. Cuomo, then Governor of New York, in his polished way, described that tendency in this manner (1985:584): 'The temptation is always there for the rich to see the poor as the victims of their own lack of ambition. For the strong to hoard their strength. For the golden circle of success to close in upon itself.'

How, then, have the community enterprises in the four studies, with their emphasis on supporting their communities and improving their well-being, practised solidarity? 
The answers will be presented under five components:

- Reciprocity

- Support of the Disadvantaged

- Support of the Community

- $\quad$ Sharing of Prosperity

- Caring.

\subsubsection{RECIPROCITY}

Laville's insight $(2003: 13)^{345}$ that the act of giving benefits also the giver through paradoxically creating an obligation for a counter gift gives us one reason why there exists an instinctive empathy for community enterprises. Support for this comes from a variety of diverse sources. The writer's prior research (Teahan, 1990, 2000) gives weight as does what appears to be an (almost) instinctive advocacy by communities over the years, for example, the creation of the trustee savings banks in the mid 1800s, and the community energy trusts in the early 1990s.

The effect of the giving is to create a contract of obligation, either spoken (specified) or inferred. The obligation may be as simple as to think kindly of the giver, or at least, not to be critical. A good deal of commercial sponsorship and philanthropy is predicated on this assumption. The terms of the gift may be quite specific; for example, the TSB Community Trust's 'requirement' that the recipient bank with the TSB Bank. The giver takes a risk in how specific and demanding they may make the terms of any gift. If taken too far, the potential exists for an adverse reaction where support turns to resentment.

345 See section 3.1 . 
Some would reject the notion that the act of giving creates anything approaching the strength of a 'contract.' But anyone who has attended a gifting function where recipient individuals and organisations are hosted by the giver would have less doubt that the forces in play do create that bond. Notably, all the community enterprises studied were well enjoyed by their communities.

There is another curious force at play here for community enterprises. An expectation is created of the delivery of certain benefits. If they are not delivered, and/or if the community enterprise becomes the subject of derision, then an adverse reaction from the community is possible, even likely. The failure of five Licensing Trusts in Wellington in the late 1990s is a classic example of the five communities withdrawing their support. In a comparative situation it is unlikely that the poor performance or demise of a private enterprise organisation would create the same public interest. If the private firm was of particular importance to a community it may generate concern and comment as for example where the firm was the major employer in an area. But that reaction palls by comparison to that when a community enterprise fails. The thwarting of community expectations thus incurs the community's wrath.

In the four studies, all community enterprises delivered benefits to their communities, usually donations of community support but also others, for example, better services. Thus the loop of expectations is closed: the community enterprise is given support by the individual in return for community and individual benefits. Support can be through product or service purchasing or unique rights, for example, exclusivity. This explains why there is quite limited agitation by the Taranaki community over representation and accountability issues. The community expectations are being met. But a fine line seems to exist. If the community enterprise pushes the boundaries of community tolerance as for example, some interviewees suggested the TSB Bank was in seeking naming rights to a number of New 
Plymouth and Taranaki icons, then reaction can occur. Another example was the catering rights for the upgraded civic theatre in Invercargill. It appeared from stories in the Southland Times that these rights were not to be tendered and would automatically go to the ILT who had donated a substantial amount of the upgrade cost. Eventually tendering did occur thus apparently satisfying the agitation.

In Eketahuna where the community support donations are not large, the reciprocity is reflected in an almost reverse way. The debenture holders' implied contract is the 'felt' need to support the two businesses their money has created. Reciprocity, therefore, can create circumstances where the giver and the receiver can interchange roles thus adding to the complexity of understanding the forces at play.

\subsubsection{SUPPORT OF THE DISADVANTAGED}

Support for those less able is a fundamental premise of the solidarity principle.

There was no evidence in any of the four studies that this pursuit was a particular emphasis of the community enterprises. Instead, their support was for the community at large, a cross-sectional support that seemed to target balance and demand rather than an analysis of need.

Eketahuna's philanthropy is quite small and limited to tertiary scholarship. Indirectly they (the collective community as represented by the ECCT) aid the less well-off in their community by the provision of local services. Those with greater affluence were more likely to have alternatives to the lack of a supermarket and service station. They could buy in bulk and farmers in particular, would have their own fuel supplies. Thus, the lack of services for this group was not as debilitating as it was for those who had more limited resources. In this small but important way the principle of solidarity was effected. 
It has been the experience of the writer that philanthropic groups tend to react rather than to target, with the important exception of the organisation that has a tightly focused objective. ${ }^{346}$ Thus, the West Auckland Trusts' community support is spread across all the community and in its annual report presentation in the local paper, donations are listed under educational, sporting, community/welfare and historical/arts. Much the same approach is taken by the TSB Community Trust (who made 1384 donations during the 2004 year and declined 35) and the ILT. Both make major donations annually but also give a good deal of emphasis to small donations to many community organisations.

While there appeared to be no specific and preferential targeting of the disadvantaged in their communities, it as well to remember that the elected and appointed trustees that represent their communities are resident in those communities, thus suggesting they have at least a good knowledge of the needs of their areas. The TSB Community Trust emphasised this in their 2004 report: 'Members of the TSB Community Trust have a wide representation and knowledge of the region and its' (sic) organisations, and therefore were able to disperse the benefits gained from the Taranaki ownership of the regional TSB Bank Ltd widely throughout the community.'

\subsubsection{SUPPORT OF THE COMMUNITY}

The cross-sectional support of the community is a feature of the West Auckland, TSB and ILT studies. Good to excellent profit generation from their trading enterprises allows significant levels of philanthropy. In effect, with no shareholders to reward for the use of capital, the dividend return is direct to the community. Eketahuna is on a much smaller scale but in recent years (2001-2003) with the immediate essential service needs of their

\footnotetext{
346 There are signs that more planning is occurring as reflected, for example, in the TSB Community Trust's December 2003 Strategic Plan. For a further treatment of some views on Strategic Philanthropy see Teahan (2003).
} 
community met, all profit generated was distributed back to the community in scholarships.

\subsubsection{SHARING OF PROSPERITY}

A feature of all four studies is their increased wealth and financial security over the past decade. As that has occurred, the beneficial communities have received significantly increased financial support.

At the beginning of the decade, The ECCT had accumulated community wealth (equity) of $\$ 28,137$ and made no donations. At the end, wealth had increased almost seven-fold $(\$ 193,856)$ and donations of $\$ 6000$ closely approximated profit for that year.

In West Auckland, donations to their communities in 1999 by the two Trusts totalled $\$ 2.012$ million. Four years later they had increased more than five-fold to $\$ 11.091$ million. Community wealth contained in the Trusts had increased over the same period from $\$ 17.793$ million to $\$ 25.923$ million.

The TSB Bank had net equity in 1995 of $\$ 44.7$ million. Ten years later that increased to $\$ 147.2$ million. In 1998 the Bank's dividend to its community was \$1.320million, in $2004 \$ 5.200$ million.

Net community wealth in the ILT more than doubled over a decade from $\$ 26.2$ million in 1994 to $\$ 58.7$ million in 2004 . Community support donations in 2000 were $\$ 6.1$ million (which represents somewhat of a distorted pattern with a large one-off donation; in 2001 donations were \$3.86million) and in 2004, \$6.748million.

Thus there is a clear and logical pattern: as the community enterprises have enjoyed increased prosperity, they have shared it with their community. 


\subsubsection{CARING}

Caring is the last component of solidarity. It implies a deeper level of commitment than reciprocity, mutuality and sharing.

Engster (2005:1) quotes Fisher's and Tronto's (1990) definition of caring as a starting point for understanding: 'On the most general level, we suggest that caring be viewed as a species activity that includes everything we do to maintain, continue, and repair our 'world' so that we can live in it as well as possible.' Engster extends that by reference to a number of other authors who similarly define caring 'as a social practice that is essential to the maintenance and reproduction of society.' In analysing Gewirth and others he contends that we have a primary duty of care towards ourselves and those to whom we have a special personal relationship, a secondary duty 'to those individuals who live in close proximity to us or with whom we share some sort of social relationship' and a general tertiary duty to care for all others in need.

Community enterprises seek to address the secondary and tertiary levels of care. How then, did the four studies exemplify caring?

Each donation made, and the community support of each community enterprise in total, reflects the principle of caring. Each donation to a greater or lesser degree represents at least 'secondary' support to a community organisation. The case studies gave examples: Ray Harper's of the Multiple Sclerosis Society support; the scholarships at Eketahuna; and the TSB Community Trust's large donation to the Taranaki Hospice.

But the caring is also at a deeper level than individual or collective donations. The community enterprises of the studies are committed to their communities. The affluent in Eketahuna did not have to support through debentures the supermarket and the service station. They more so than the less advantaged in the community had alternatives. The level of commitment by Trustees and Management at the ILT to ensure benefits are maximised 
would be observed by only a small few and was often a good way beyond any personal reward or expectation normally associated with the roles. In the vignettes, the Flaxmere Trust's immediate response to a fire tragedy in their (generally) lower income community was to mobilise leaders and organise at the Trust's cost the installation of fire alarms in every home.

Caring, therefore, is well exampled in the case studies and the vignettes. Of course, it is not always present, nor does it always need to be. At times, donations would more reflect expediency (the funds are available and we need to distribute them) and very little commitment other than to resolve that a sum of money be gifted. But that does not detract from the essence that are community enterprises and which is their major point of difference compared to the dominant structure in business society, private enterprise. Community enterprises seek to generate profits from their trading enterprises so that they enhance the well-being of their community. To do that implies caring.

\subsubsection{CONCLUSION}

Solidarity is a powerful concept but a difficult one for many. It requires a commitment to others' welfare that transcends self. Community enterprises are a vehicle and an opportunity to implement the ideals. The case studies in Chapters 5-8 profile the processes and the successes of these community enterprises in the practice of the concept; a practice that was well pursued in all four studies.

\subsection{ENTERPRISE}

Five elements encompass the enterprise component:

- Use of Personal Skills

- Creativity and Innovation

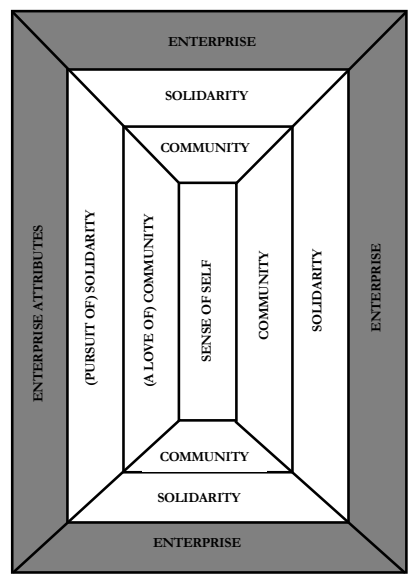


- Risk and Reward

- Incentives

- Governance and Agency.

The presence of these themes and nuances in the four case studies will be considered under these headings.

\subsubsection{USE OF PERSONAL SKILLS}

Section 2.2.4.2 explains why there can exist a personal wish to contribute individual skills to a community organisation. Section 2.2.1 exampled the vignette of the long serving members. Whether a desire for personal growth or altruism, the commitment to contribute is a common one, arguably an instinctive reaction to the circumstances of life in which one finds oneself and partially explained by Maslow's hierarchy of needs and Jensen and Meckling's (1994) The Nature of Man.

The four case studies are resplendent with examples. The 'band of six' and notably the Chairman of the ECCT, John Harman, displayed a unique level of commitment and 'street smarts' in Eketahuna. The elected and appointed trustees of the West Auckland Trusts, the TSB Community Trust and the ILT to varying degrees reflected this component. The former President of the ILT, Ray Harper's level of dedication was remarkable and beyond what he either could or would explain. For some the fees that they earn may be a partial or even complete reward for their involvement but apart perhaps from the TSB Community Trust where they are likely to be a reasonable recompense for time spent, the paucity of financial reward provides no or very limited justification for their involvement. ${ }^{347}$ The ILT General Manager's statement during the interviews that he would not be as committed were it

\footnotetext{
347 Eketahuna Trustees received no fees; in the 2003 financial year, the seven Waitakere Trustees were paid a total of $\$ 39,000$ and the ten Portage Trustees paid $\$ 23,000$; in the 2004 financial year the ten TSB Community Trustees were paid a total of $\$ 73,720$; and in 2004 the six ILT Trustees were paid total fees of $\$ 58,800$.
} 
not for the community ownership of the Trust gives a further example of management dedication beyond financial reward.

\subsubsection{CREATIVITY AND INNOVATION}

These components are synonymous with private enterprise and capitalism. Michael Novak explains (1991:129) that democratic capitalism 'awakens individuals and nations to their own capacities for imagination, self-improvement, and growth.' Seldon (1980) reinforces the effectiveness of private enterprise by claiming that it has delivered 'better results in living standards than any other system...' Creativity and innovation are the life-blood of any business organisation. How then did the case studies example these attributes?

The writer has made no secret of his admiration for the ingeniousness of Eketahuna's leaders. The individual parts of the solutions may not have been uncommon but the way they fitted the pieces together provided a unique 'Eketahuna' solution.

In West Auckland the creativity that was brought to the competition poll by the trusts was the defining difference in the poll's outcome. The Trusts were recognisably smarter. Innovation is common too throughout their community support programmes. The household gifts, the support to schools and the partnerships they have forged with other community organisations, for example, the Waitakere City Council in the recent construction of the stadium, have all, arguably, broken new ground.

The TSB Bank has a reputation for innovative leadership. It lists a number of examples in its publication 'Your kind of Bank': the first to offer free, interestbearing cheque accounts, the first to operate their own realty company and travel agencies, and technological firsts.

The ILT's successes both in business and in its support for the Invercargill community are a feature of the case study and, like the TSB, the ILT could list 
a good number of innovations, for example, their educational support for teachers, their partnerships with other community organisations in the zero fees scheme, and their understanding and use of strategic philanthropy.

\subsubsection{RISK AND REWARD}

As section 2.2.4 highlights, an implied characteristic of enterprise is the acceptance of risk at the level and scope found tolerable. Reward, seen in the broadest light, often has a correlation to risk and usually is the driving factor behind the level of risk found acceptable. A degree of risk is inherent in any undertaking. Rarely is an outcome so certain that the result can be entirely predicted. Nobel laureate Kenneth Arrow charmingly warns us (1992:46): 'Our knowledge of the ways things work, in society or in nature, comes trailing clouds of vagueness. Vast ills have followed a belief in certainty.'

Thus, the acceptance and 'taking' of risk is essential to progress. Bernstein (1996:1) tells us that '...risk-taking (is) one of the prime catalysts that drives modern Western society. The transformation in attitudes towards risk management ...has channelled the human passion for games and wagering into economic growth, improved quality of life, and technological progress.' Accepting this, what has been the prevalence of risk taking in the four studies?

The leaders of Eketahuna went into unknown territory when they sought debenture funds from the public to operate a supermarket. The operation of a community supermarket had a precedent and they were able to visit and talk with the Manager and representatives of that area. The debenture idea had been tried before in clubs so the extension into a community model was not that great a risk. They quickly learnt, however, that the operational responsibility for a supermarket by willing but not necessarily knowledgeable amateurs was a large risk and moved within a year to a lessee taking operational responsibility. Providing a cheap rent by way of subsidy had some financial risk but the interest free debentures helped and so long as they did their budgets well, they would survive. The greater risk was operational 
failure, hence the need to keep rents low and the community's purchasing support high. By the time the need for a service station arose 13 years later, they were confident in their model and simply extended what they had learnt into that project.

The Licensing Trust model was fraught with risks. In the 1940s, everything was new for the ILT trustees. They had to learn how to construct and operate bars and hotels when there was little precedent. They had no equity capital although the Government helped with a loan and guaranteed overdraft, the only time they were to do so for a Licensing Trust. When the West Auckland Trusts started in the early 1970s, they had a number of successful, and a number of struggling, Licensing Trusts as examples but the financial risks were still significant. Invariably, a Licensing Trust had to borrow $105-110 \%$ of the cost of an outlet merely to become operational. In these circumstances, it is no surprise that the Trusts were innovative. To survive, they had to be. ${ }^{348}$

The TSB Bank identifies in their documents ${ }^{349}$ that the community ownership model exposes them to the risk of a lack of ready access to capital. They compensate, they state, by higher capital adequacy ratios and a low dividend return. The degree they are influenced by this or by conservatism is likely to be a continuing source of debate in the years ahead.

This thesis' methodological emphasis on 'an informal deliberative framework of practical reason', 'data examination through conflicting frameworks' and a 'multi-disciplinary approach' gives encouragement to a judgment on whether the community enterprises in the four studies were more risk adverse than their private enterprise counterparts. On balance, the judgment would be no although The TSB Bank on capital adequacy ratios clearly are. Yet the same bank has been a leader in its field and just as clearly prepared to take risks. All four studies show a similar pattern - they are leaders in a number of identified

\footnotetext{
348 For a more extended treatment of these issues see Teahan (1990), The Sale of Liquor in New Zealand Report of the Royal Commission of Inquiry (1974), Bollinger (1967), and Lind (1994).

349 See chapter 7 for references and discussion.
} 
ways, yet their preparedness to take risks appears to be soundly based and achieve a high percentage of success. Their financial results and stability are two measures in support. While it would take a more detailed comparison with private enterprise models to identify the degree to which the community enterprises were more or less risk accepting, 'practical reason' suggests they could not have achieved the results they have, and which compare favourably with private enterprise, without at least an equivalent tolerance.

There is of course a much wider element to risk than financial reward and security. For public bodies and the individuals who lead them, there is the social risk of failure and rejection. Consider the trepidations of those in Eketahuna who called the first public meeting. Until the first feedback starting coming in, the fear of rejection was present. They overcame that by doing what Eketahuna is very good at - networking extensively. The possibility of failure is still remembered almost 20 years later by one key player, the then Mayor, when the TSB Bank decided to go it alone. A prominent banker from one of the major banks bet him with a warning: 'you won't last 6 months. 350 Public elections for the three licensing trusts of the major studies are a triennial exercise in public trust. Sitting trustees effectively are given a scorecard on their performance. If well supported by the community they are given a vote of confidence; if not, rejection. The West Auckland polls are a scorecard too on risk, performance and trust.

These feedback mechanisms and the periodic reinforcement or rejection through casual conversation, and community and media agitation are an effective and sometimes very powerful way of communicating public trust. That the community enterprises studied were well aware of their potential influence is reflected in their recognition and receptivity, and in how well they managed the processes. 350 The now ex-mayor takes some considerable satisfaction from winning the bet (which has yet to be
paid by the banker!) 


\subsubsection{INCENTIVES}

Like many other sub-issues in this thesis, the topic of incentives is an immense one that on its own could be the subject of research for community enterprises; for example, what were the incentives that motivated the small group of people in Taranaki in 1986 to agitate for the retention of 'their' bank; what alternative incentives did the Eketahuna people receive to so readily accept giving their money without the incentive of interest payments; and what incentives did the West Auckland voters substitute for waiving their opportunities to purchase liquor in supermarkets? These questions presuppose that incentives were present and that Jensen and Meckling (1994) are correct when they state: 'It is inconceivable that purposeful action on the part of buman beings can be viewed as anything other than responses to incentives. Indeed, the issue of incentives goes to the heart of what it means to maximize or optimize, indeed to the very core of what it means to choose. Rational individuals always choose the option that makes them better off as they see it.' 'This view is not what some are comfortable to accept, as Jensen and Meckling record. Their seminal article is motivated as a response to Brennan's (1994) on 'Incentives, Rationality and Society' wherein Jensen and Meckling claim that 'Brennan appears to desire a world in which there are no incentives, and at times seems to believe that action in the absence of incentives is the natural and, therefore, desirable state of affairs. Many managers, policy makers, and religious leaders share this view.'

This writer accepts Jensen and Meckling's view that incentives do always exist and that it is human nature to select those that best suit the time and circumstances. For some, their motivation may be consistent over a long period of time. For others, incentives may be hugely variable. Contrary to a greed philosophy, people are motivated by a range of incentives JJensen and Meckling, 1994) which most often will be hierarchal (although the order of importance may vary). Somewhat as a side issue, this explains why where optimal financial performance is sought, money incentives are necessary (Jensen and Meckling, 1994). 
This brief discourse does not seek to be a definitive treatise on the contentions surrounding incentives. Rather, it acknowledges the complex world that exists of which incentives play a motivating force; a force which is frequently only partially understood. The choices can be as variable as the mindsets of the participants, as the West Auckland case study identifies.

It is simply a logical extension from what precedes, to state that motivating incentives were constantly present throughout the four studies. The Eketahuna people had incentives of personal benefits, and the common good - the 'altruistic concerns for the welfare of others' (Jensen and Meckling, 1994). West Aucklanders were primarily concerned to ensure the benefits they received from the Trusts were not at risk, and was there even a perverseness that rebelled at being labelled the same as other parts of Auckland and New Zealand? Were personal territories, the historic idea of 'fiefdoms', a more dominant factor in Taranaki? And in Invercargill, to what extent was commanding and competitive leadership the key motivating influence?

\subsubsection{GOVERNANCE AND AGENCY}

Research into, and knowledge of, good governance and accountability mechanisms continues to advance. Best practice is helpful to ensure that what works well, and does not, is better known and understood. But it is as well to recognise that governance practices have a tendency to be fashionable and reactionary to the pressures of the times. Thus, the ever increasing accounting disclosure requirements may be seen, partially but significantly, as a reaction to the failures of the Enrons. Another example of fashionable reaction was the emphasis given in the latter part of the past century to separate out enterprise goals from social/community goals by placing their responsibility with different organisations. ${ }^{351}$ Experience has shown that this is desirable in some circumstance but as the Invercargill Licensing Trust examples, not all.

\footnotetext{
${ }^{351}$ For example, the Trustee Savings Banks and the electricity companies.
} 
Fashionable or not, good governance materially helps an organisation to achieve its goals. Institutes of Directors are often good sources for Codes of Proper Practice, Working Guides for Directors' Responsibilities, and Statements of Best Practice. ${ }^{352}$

Good governance may be broadly categorised into two dimensions: control and accountability mechanisms, and enterprise principles. The latter is arguably more important. As Novak (1997:18) notes that unlike Government 'the problem of corporate governance is not to check power - that is already done today by unprecedented dimensions of competition - but rather to summon up and channel power.' What Novak is emphasising is the need for any trading entity to exercise enterprise. If both the formal and informal bounds stultify, the enterprise will, sooner or later, be at risk. Good governance practices include the definition of goals, clear lines of responsibility and accountability, good reporting and communication relationships, diligence, and high ethical standards. To what extent, therefore, were these present in the four studies?

The ECCT is a small organisation where elected representatives undertake the tasks voluntarily. Thus, governance is rarely other than 'hands on' management and implementation by the Trustees. There is a simple focus on what they wish to achieve, annual meetings, regular discussion and good to very good communication with the community.

The West Auckland Trusts have moved in recent years to separating out the business function under a separate board of directors with defined responsibilities and accountability. Elected Trustees are on this Board thus allowing for better communication with the 'owning trust' (but also raising the possibility of conflicts of interests which are more likely to be political than enterprise) and 'outside' directors are appointed to strengthen expertise. Good written definition, which includes managerial position descriptions,

\footnotetext{
352 For example, see the Institute of Directors in New Zealand web-site www.iod.org.nz.
} 
better ensures that areas of conflict are lessened and contained. They also allow managers to manage. Good practice is thus reflected at all levels.

Separate Boards with defined powers, strategic long term plans, and generally ${ }^{353}$ good accountability mechanisms are a feature also of the TSB case study. The spirit of enterprise is particularly strong.

There is strong definition and practice of excellent governance processes at the ILT. Here there is one Board that seeks to integrate enterprise and community functions both at the strategic and operational levels with the result that their focus on enhancing the well-being of Invercargill is notably strong.

In summary, good governance and agency principles are strongly present in all four studies.

\subsubsection{CONCLUSION}

Enterprise, at its core, is a personal concept. ' $A$ daring spirit, a bold attempt' ${ }^{354}$ is the underlying meaning that may be extended into 'entrepreneurial economic activity $^{335}$. To undertake and achieve these requires, firstly, an individual's dedication which is then broadened into community association and commitment. Thus, as the schematic attempts to depict, all the concepts are interwoven, as is enterprise. It is not possible to define where one starts and the other ends. Their presence at any point is subject to a significant variability. We can analyse and identify component parts that may to a greater or lesser degree be present. But ultimately we are frustrated in our ability to define. We will arrive at a point that Fowler (1991) and many others reach. We will restate like Fowler (:155) that the individual is the story in community

\footnotetext{
353 Generally, because the accountability loop to the community is not strong.

${ }^{354}$ Definition from Webster's dictionary.

355 Definition from the New Oxford Dictionary of English.
} 
and in community enterprises, that (:161) the concept 'is too rich to be pinned down tightly' and 'that vibrant community is always open, always in progress.'

\subsection{CONTENTIOUS ISSUES}

There remains to analyse the impact of the three contentious issues in the four case studies; that is, how well the community enterprises coped with the effective pursuit of a mixture of economic and social/community goals, the 'ownership' dilemma (for some) and the need for (or over reliance on) profit, in effect a question of equity.

\subsubsection{THE MIXING OF GOALS}

The contentiousness present with this issue is theoretically defined in section 2.3.1. Two of the community enterprises (TSB study and the West Auckland study) separated out responsibility for the economic function from the social/community role, although the parent or 'owning' body retained final control. The ECCT (although in a small way) and the ILT undertook the two roles under one organisation. In all four studies the ultimate responsibility for both the business/trading and social/community functions rests with the 'owning' board. As the case studies show, all worked well thus reinforcing a view that there is not one model that fits all and effectiveness depends on local prevailing circumstances.

\subsubsection{OWNERSHIP}

Section 2.3.2 outlines the theory of ownership of community enterprises. In summary, community ownership is multi-textured and can not be restricted to the lens of private enterprise models. Communities exhibit both overt and covert ownership signals which were commonly present in the four studies.

The community's ownership of the ECCT was shown by the attendance at the public meetings, the debentures taken up and not redeemed, a 
preparedness to accept no interest (the 'dividend' return was in other benefits), and in the retail support.

In West Auckland, the poll outcome reflected the majority's view on ownership; as one focus group asserted: 'It's our Trust.' The public meeting support and the prominent profile of the Waitakere Mayor and MPs indicated at least an awareness of where their constituents' loyalties lay, but also their backing. Informal feedback to Trustees and management, newspaper articles, letters to the editor, and voting turnouts all suggest a lively interest in the Trusts.

The decision to go it alone in 1986 had to receive at a minimum the tacit support of the Taranaki community for the TSB. Over the years since then there have been few signs of overt ownership. Poor attendance at the AGMs of the Community Trust, the quite limited agitation on dividend levels and political appointments suggest either a community complacently happy or not caring. Alternatively, the $97 \%$ customer satisfaction levels consistently resulting may be seen as one barometer of ownership.

That the supermarkets are not prepared to test a poll in Invercargill as they have in all other parts of New Zealand where a similar position exists, suggests there is no confidence that they would win. By implication therefore, this supports anecdotal information that the level of community support for the ILT is high. Internal polls taken by the ILT were said to support this view. Frequent comment in the media and letters to the editor again indicate a high level of interest. Triennial elections are lively contests, well supported by aspiring candidates and by the community.

\subsubsection{THE NEED FOR PROFIT}

The importance of profit for equity generation (and by extension, satisfactory financial performance and acceptable financial indicators) is explained in section 2.3.3. All four studies highlighted good to outstanding results thus 
suggesting that satisfactory financial performance receives significant emphasis.

\subsection{SUMMARY}

To conclude this cross-case analysis, it is possible now to summarise in table form the presence of the 21 sub-components of the community enterprise schematic in the community enterprise studies in chapters 5-8. The postpositivist methodology encourages such an analysis even if a subjective element is inevitable in doing so. Having examined the data through a multidisciplinary and multi-methodological approach, applied practical reason for its insights, and attempted to describe a rich perspective of human affairs, it is appropriate to make 'craft' judgments on the presence of these elements in the community enterprises studied. To do so will better allow conclusions to be reached in the next chapter on the circumstances in which community enterprises are likely to best flourish.

The categories in Table 9.2 are simply defined. SP represents the component was strongly present. MP indicates a mild presence. NP reflects a judgment of no presence. NK denotes that it could not be decided or that it was not known whether the component was present. Not answerable could be an alternative category for the latter in that the time and circumstance of the study did not allow a judgment to be reached. In a small number of cases, alternative categorisation could occur and these are explained in the footnotes. 
TABLE 9.2

PRESENCE OF COMPONENTS IN CASE STUDIES

\begin{tabular}{|c|c|c|c|c|}
\hline $\begin{array}{l}\text { COMMUNITY ENTERPRISE } \\
\text { COMPONENT }\end{array}$ & ECCT & WA & TSB & ILT \\
\hline $\begin{array}{l}\text { SENSE OF SELF } \\
\qquad \quad \text { Shared culture }\end{array}$ & MP & MP & MP & MP \\
\hline - Bounded locality & SP & $\mathrm{SP}$ & $\mathrm{SP}$ & $\mathrm{SP}$ \\
\hline - Referent of identity & SP & SP & SP & SP \\
\hline - $\quad$ Boundaries threatened & SP & SP & $\mathrm{MP} / \mathrm{SP}$ & $\mathrm{MP} / \mathrm{SP}$ \\
\hline - Self-fulfilment & SP & $\mathrm{NK} / \mathrm{SP}^{356}$ & $\mathrm{NK} / \mathrm{SP}$ & $\mathrm{SP}$ \\
\hline$\frac{\text { COMMUNITY }}{\bullet \quad \text { Belonging and inclusion }}$ & SP & MP & MP & MP \\
\hline - $\quad$ Common good & $\mathrm{SP}$ & $\mathrm{SP}$ & SP & SP \\
\hline - Community well-being & SP & SP & SP & SP \\
\hline - Social networks & $\mathrm{SP}$ & $\mathrm{SP}$ & $\mathrm{SP}$ & $\mathrm{SP}$ \\
\hline - Bonds of trust & SP & MP & SP & SP \\
\hline $\begin{array}{l}\text { - Confidence in public } \\
\text { institutions }\end{array}$ & SP & $\mathrm{MP} / \mathrm{SP}$ & SP & SP \\
\hline$\frac{\text { SOLIDARITY }}{\bullet \quad \text { Reciprocity and mutuality }}$ & SP & SP & SP & SP \\
\hline $\begin{array}{l}\text { Support of the } \\
\text { disadvantaged }\end{array}$ & MP & MP & MP & MP \\
\hline - Support of the community & SP & SP & SP & $\mathrm{SP}$ \\
\hline - Sharing of prosperity & SP & SP & SP & SP \\
\hline - Caring & SP & SP & SP & SP \\
\hline$\frac{\text { ENTERPRISE }}{\text { - Use of personal skills }}$ & SP & SP & SP & SP \\
\hline - Creativity and innovation & SP & SP & SP & $\mathrm{SP}$ \\
\hline - $\quad$ Risk and reward & SP & SP & SP & SP \\
\hline - Incentives & SP & SP & SP & SP \\
\hline - Governance and agency & SP & SP & SP & $\mathrm{SP}$ \\
\hline
\end{tabular}

356 The ambivalence of this and the following categorisation occurs because there were suggestions of a strong presence but not confirmed. 
Chapter 10

\section{CONCLUSIONS}

Come, my friends,

Tis not too late to seek a newer world.

From the Ulysses by Alfred Lord Tennyson (1809-1892)

Giddens' (1999), Stiglitz' (2001) and Putnam's (2000) pleas for new and renewed institutions are a theme of, and one of the motivating forces for, this dissertation. There is an intuitive logic to their petition, even before acknowledging their compelling arguments. The renewal and the birth of organisations are necessary to the vibrancy and growth of communities and society, not just in New Zealand, but throughout the world. This need is one of the enduring fundamentals of growth: as one philosopher said (ben Shea, 1989): 'what grows never grows old'.

Some organisations and some organisational structures have a greater capacity to endure than others. Where they are valued (or, more deeply, loved), the desire for retention logically is stronger. So it is for the TSB Bank (now over 150 years old) and the Masterton Trust Lands Trust (over 130 years old). An important question for this thesis, perhaps the most important, is whether community enterprises are part of the mix of new and renewed institutions that is most desirable, or, more strongly, required, for the century ahead; and more critically, whether they have the characteristics that will help them continue to endure. These characteristics may take the form of inherent advantages and/or fewer weaknesses than the alternatives. This thesis seeks to answer those questions, and thereby contribute to the stock of knowledge about institutional ebbs and flows while also advancing community enterprises as an option for future generations of institution builders. 
Therefore, this chapter will be organised around six propositions:

- The characteristics of community enterprises are best described via four essential principles - sense of self, community, solidarity, and enterprise, which also explain why community enterprises are enduring and endearing institutions historically, and in the modern world.

- Community enterprises are best engaged under circumstances in which the four characteristics (listed immediately above) interact and unite to form a coherent whole.

- When communities are threatened with the loss of something they value, they will react/mobilise to protect/defend. This is a defining characteristic of communities, as Cohen (1985) well argues, and helps to explain why community enterprises are formed, and why they endure.

- Community enterprises are not 'ownerless', which is contrary to McKinlay's (1999) central inference. Ownership should not be viewed through the lens of private enterprise, but as an extension of Jensen and Meckling's (1994) work.

- The pursuit of mixed (that is, economic and social/community) goals does not inherently impair performance.

- 'The slow infiltration of politics' (Spicer et al, 1996:187) does not necessarily debilitate the performance of community enterprises.

\subsection{A FRAMEWORK FOR COMMUNITY ENTERPRISES}

Chapter 2 provided the following definition: 
A community enterprise is a business whose primary goals are to support the well-being of its defined community principally through reinvesting profits generated from its trading activities either in the business and/or in support of community activities, rather than being driven to maximise profits.

Thus, a community enterprise's primary goals are the well-being of a defined community which may be geographic or categorical, for example, intellectually handicapped people, the disabled, a sporting group or those in need of employment. Business performance goals are secondary, though still very important and demanding of high standards, for if not, survival may be threatened. But economic goals are supplementary to, and supportive of, the well-being goals. If, for example, the support provided is to create employment opportunities for the disadvantaged, then to achieve this, profits may be reinvested in the business rather than distributed to charity. A fundamental premise is that profits will be sought and achieved. No less rigorous standards of performance than private enterprise may be sought. The emphasis here is 'may'. The drive for profit is conditioned by the primary goals. The community enterprise may choose to maximise profit performance if that best suits its objectives. A private enterprise structure may also choose not to maximise profit but by definition its primary objective is wealth creation, remembering Friedman's (1970) classic one liner: 'The business of business is business.'

The definition is similar to that provided by the UK government's document (2002) for Social Enterprises. ${ }^{357}$ The OECD (1999) also provides definition and analysis of roles and scope, predominantly in Europe. While social enterprises may be viewed as sister organisations to community enterprises,

\footnotetext{
357 The UK definition: 'A social enterprise is a business with primarily social objectives whose surpluses are principally reinvested for that purpose in the business or in the community, rather than being driven by the need to maximise profit for shareholders and owners.'
} 
the latter would tend to have a greater emphasis on community linkages and $\operatorname{support}^{358}$.

\subsubsection{THE COMPONENTS’ SCHEMATIC}

Four components provide the theoretical and philosophical bases to the concept of community enterprises, as represented by the diagram in figure10.1:

FIGURE 10.1

\section{THE COMPONENTS OF COMMUNITY ENTERPRISES}

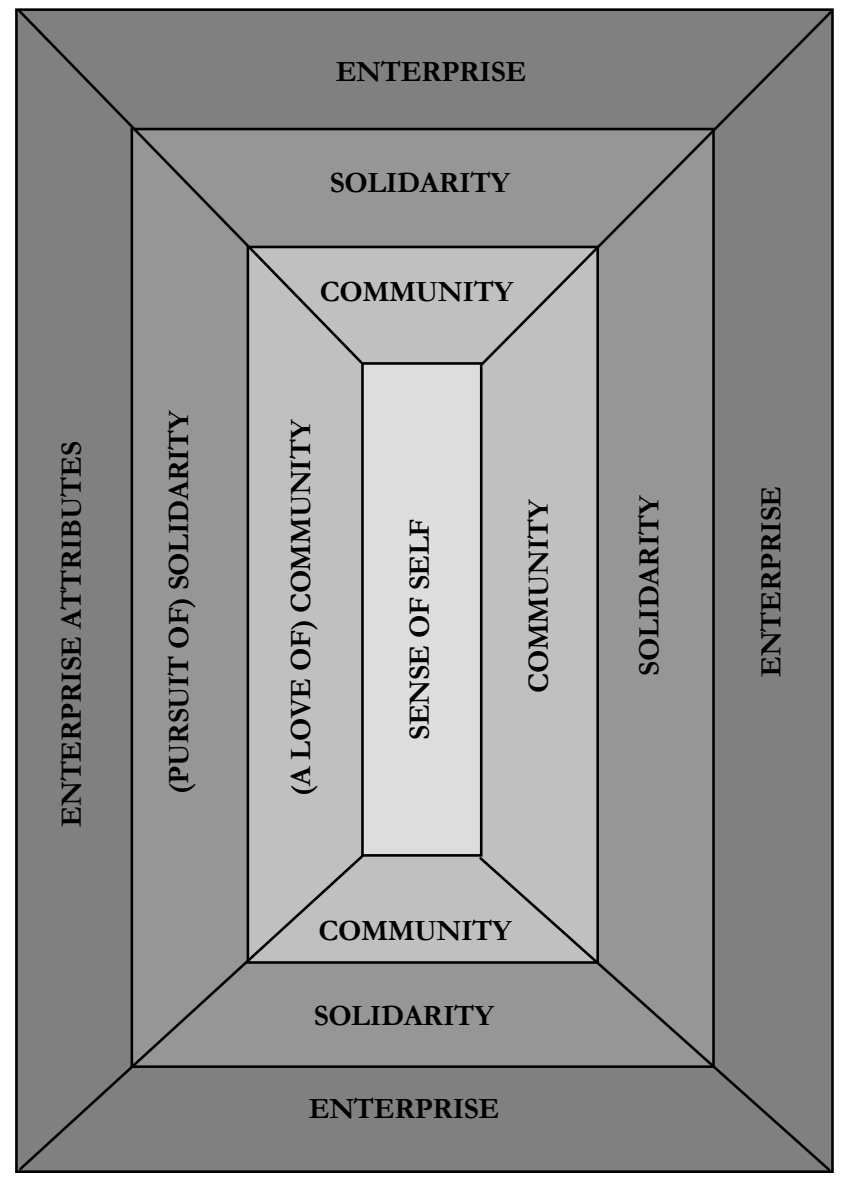

358 But social enterprises may also pursue community support goals. 
The inner core is Cohen's (1985) sense of self. His expressive words (:117) establish the foundation: '...the survival, the burgeoning, the assertion of community (is) not .... an aberration to be explained, but... a normal, expectable expression of the resilience of culture: of people's sense of self;' the greater the fear that something important may be lost, the greater is the likely reaction. Cohen probably did not have in mind the concept of community enterprises when he wrote these words, for none of the cases he records in the 'The Symbolic Construction of Community' (1985) are linked to trading enterprises. Nonetheless, the link that he draws between individual and group expressions of identity - that is, between community-based activity and the cultural expression of people's sense of self - clearly captures an essential dimension of the phenomena described in this thesis' case studies.

The community association in community enterprises is often very personal: a desire to enhance self by community association. By extension, community enterprises frequently express and reinforce an instinctive empathy. In effect we can relate to them because they are an extension of our selves. But there can be a fine line between empathy and aversion as there often is between opposites. When things go wrong aversion may dominate, as for example, where individualism (that is, selfish aspirations) is paramount, and where community enterprises perform poorly and become the subject of derision. But Berger's (1998) dark side of community ${ }^{359}$, while ever threatening, neither needs to dominate nor even occur.

To repeat from a different perspective: the starting point for community enterprises is the individual. When Fowler (1991:155) wrote that 'the individual is the story in community' he was reasserting that difficult to grasp paradox: community association begins with individual needs. Community enterprises have been born, and will continue to be born, because they represent at that time and place the most appropriate answer to the issue being addressed. In the TSB example, it was the need for thrift and investment capital. For

${ }^{359}$ See note 35 . See also section 2.2 .2 for a fuller treatment on community. 
Licensing Trusts it was concern on the impact of sensitive products on the community. For Eketahuna, it was the need for essential services. But these needs were born out of the individual; individual needs that 'had' to be met. ${ }^{360}$

But there are also deeper needs that 'had' to be met. In each case, the need or motivation that propelled the individual organisers was also about identifying with a larger cause outside the individual self. The need to 'transcend self is inherent: Maslow's (1954) esteem and self-actualisation needs, James's (1961) spiritual. ${ }^{361}$

Like Cohen, Fowler was unlikely to have in mind community enterprises when he wrote his scholarly treatise 'The Dance with Community' (1991). He was concerned primarily with the search for community more broadly, but in his musings on capitalism and economic democracy we can see elements of the concepts that community enterprises embody. This thesis does not, of course, attempt to encompass the broadness of Fowler's 'journey in contemporary intellectual history' (:ix), but rather to practically marry his analysis and vision of community with trading enterprises. It may thus be seen to be partially an extension of Fowler's analysis and partially new ground in the context of community enterprises.

The love of and need for community is the second component and flows from the first. William James' quote at the start of section 2.1.3 ('The community stagnates without the impulse of the individual, the impulse dies away without the sympathy of the community') highlights how interwoven are the linkages between the individual and community. Fowler (1991) is correct when he tells us that 'community goes deep into our souls'. To be able to separate out the individual from

\footnotetext{
360 'The 'had' to be is, of course, relative. Circumstances compel solutions. If the mix (of people, needs, resources, values, beliefs, prevailing ideologies...) had been different what may have eventuated? There are always those who see value in attempting to second guess history. And the vigour of that debate probably bears some relation to the degree of belief in destiny.

361 For a treatment of these issues, see section 2.2.1.
} 
community - to define where one starts and one ends - is well nigh impossible. The two are inextricably linked.

Community association offers inclusion, a sense of belonging and by extension, the notion of the common good and the concept of community well-being. The literature reviewed, and the case studies exampled, provide rich arguments in support of the essentiality of these four factors in an ideal society.

The third component is the pursuit of solidarity. This powerful concept offers much to an ideal society and is inherent in community enterprises. It may be defined as a preparedness to help those less fortunate; in Henry Ward Beecher's expressive words: 'If any man is rich and powerful he comes under the law of God by which the higher branches must take the burnings of the sun...' Notably, solidarity is a fundamental principle underpinning the growth of the third sector described by Laville (2003) and Salamon (2003). Its increasing impact may be seen as a counter-balance to globalisation. The market economy by its creation of winners and losers tends to distort the fine balance required for a fair and caring society. Extreme wealth mixes too comfortably with alienation. Gaps of availability of surplus resources and unmet needs thus arise.

Laville's (2003) insight that the principle of reciprocity underpins solidarity 'moves' the concept from a 'high-minded ideal' to a desirable and beneficial contract between people. Solidarity embodies both self-interest and a caring for others. The act of giving benefits also the giver. The 'paradox' (Laville, 2003:13) of the gift is the 'obligation' created, which in turn potentially and practically lessens alienation and offers avenues for inclusion.

The fourth component is enterprise, which has several layers of meaning. At one level it is a category, for example, a business unit. At another, it represents the degree of initiative and resourcefulness brought to the venture. At still another, it is the desire to use personal skills for the benefit of the community. Enterprise embodies initiative and resourcefulness thus encompassing all 
those attributes essential for success: enthusiasm, commitment, skills, management and personal disciplines, profit, return on investment, people skills...which, while they may be generic, are inherent in the enterprise concept.

A distinctive feature of community enterprises, as contrasted with enterprises generally, is the desire to use personal enterprise skills for the benefit of the community. Once again the linkages and interwoven nature of the component parts of community enterprises are apparent: the personal and the individual interact and interchange with the collective community.

It may be argued that an individual does not need a community enterprise to be able to apply their personal skills for the benefit of the community. That can be done privately and through private enterprise as per Adam Smith's (1776) pivotal insight that man best serves others by serving themselves, and Novak's (1991:92) concept of virtuous self-interest. But a vehicle such as a community enterprise that channels resources and eases the alienation and exclusion barriers materially aids the process of transforming self interest into collective gain. In addition, it often does more than this, as when the institution of community enterprise itself becomes a reminder of community need, and of the obligations on community members to fill these needs for each other.

Will the desire to use personal skills for community benefit always be present, and if so, to what degree? This thesis argues that such desire will always be present, although the degree of presence will vary. Sometimes it will be muted as in the case of the TSB and sometimes dominant as in the cases of Eketahuna and the ILT.

It may be argued that it is a large leap from the case studies (see chapters 5-8) to asserting that the desire to use personal skills for the benefit of the community will always be a feature of community enterprises. Some degree of qualification is necessary. For example, will it be (always) present for all the 
700 employees of the ILT? The answer must logically be no. For some it will be present from time to time. Some will take pride in working for a community organisation that impacts positively on the region. Others will see their employment as 'merely' a job. As the organisation becomes bigger the desire is likely to become more remote and harder to detect. It is clearly easier to see the linkages between desire and action in a small organisation like the ECCT where all effort is voluntarily given.

At the elected representative level, that is, the trustees of the case studies, the question may again be asked: will their involvement (always) be driven by the desire to help and support? Again, the answer must be no, it will not always be present. There will be multiple reasons why individuals put themselves forward for election and representation. Some reasons will be personal and 'selfish', for example, the personal growth of the trustee in the vignette on The Case of the Long Serving Members. ${ }^{362}$

But these qualifications are natural limitations to the theme, not rejections. Throughout the case studies and vignettes the theme of association based on desire to support was a regular presence. The writer's many years of practical experience of community enterprises strongly reinforces that view.

\section{SUMMARY}

The components schematic explains what community enterprises are. Cohen's work provides a starting point to which Fowler adds clarification. But their lines of argument, while helpful, are not specific to this thesis. They are necessary but not sufficient. To explain community enterprises and the roles they play requires stepping beyond these authors and including others who can contribute parts to their essence. That is why Novak's work on democratic capitalism, Seldon's on private enterprise, Gewirth and Wojtyla (John Paul II) on solidarity, Putnam on social capital, Jensen and Meckling on

\footnotetext{
362 See section 2.2.1.
} 
ownership, and Laville and Salamon on the third sector, are important contributors. Community enterprises may be seen today as a hybrid form of organisation crossing over sectors. They are not wholly market or private enterprise; they are not Government; they are partially philanthropic; they are essentially community support. If categorisation is necessary, they fit best in Laville's (2003) hybrid third sector. ${ }^{363}$

\subsubsection{THE DEGREE AND IMPORTANCE OF PRESENCE}

Defining what community enterprises are and their component parts gives rise to questions of degree and importance. Is it necessary for each component to be present? To what degree should (ideally) each component be present? Is there an ideal balance?

This thesis argues that each of the four components must be present in order to qualify as a community enterprise. Take away the 'impulse of the individual' (James) and community enterprises will not be born. Take away community and it becomes a private (philanthropic) enterprise, albeit committed to a greater degree of social responsibility than most. Take away solidarity and local private enterprise results. Exclude the enterprise and you have a nontrading philanthropic trust.

There can be no one right balance or mix of components. Indeed, there is an almost infinite range of possibilities. The diversity of the case studies in chapters 5-8 support this assertion. For some, the emphasis is on enterprise, and for another, on community support but all encompass all four elements in different proportions. The case studies show that each of the components

\footnotetext{
363 An interesting challenge to research would be what came first in the history of endeavour, private enterprise or community enterprise. It is a modern tendency to see private enterprise as pre-eminent, in effect the starting point. The author does not seek to lessen its status and importance but was occasionally moved to wonder what did come first in history, private or community enterprise? While a limited amount of research was undertaken to see how far back the concept of community enterprises could be traced, the answer was only peripherally of interest to the issue of how enduring they are, and abandoned when it became clear that the answer was likely to be very time consuming. But, perhaps, one day...
} 
can be as variable as the human imagination, and that variability logically extends into the whole.

\subsubsection{THE SUM OF THE PARTS}

It is the sum of the four components of figure 10.1 - sense of self (which has a number of other names, for example, self-fulfilment, self-actualisation), community, solidarity, and enterprise - that gives rise to the concept of community enterprises. A community enterprise is unique in its emphasis on community support achieved through enterprise (trading) activity.

\subsubsection{ARE COMMUNITY ENTERPRISES NECESSARY?}

It is relatively easy to answer in the affirmative to the question of whether community enterprises are desirable. It is more difficult to judge the degree to which they are necessary to enhancing a community's quality of life. One way of answering that is to look at the examples in this dissertation.

The research for this thesis included examination of 38 community enterprises, some intensively and extensively as reflected in chapters 5-8. Others are the source of the vignettes. Some are subsidiary bodies of the parent community enterprise with 26 parent bodies out of the field of 38 . The author also benefited from research in 2000 on the energy companies and their owners, the energy community trusts ( 26 in all) which may be classed as fringe ${ }^{364}$ community enterprises. Although dominated by licensing trusts (which comprise 22 of the 26 parent community enterprises), this pool is large enough to draw upon to answer the question of necessity. The answer emerges in a tiered fashion.

The first level, and perhaps the lowest tier, is to review the benefits provided by the 26 parent community enterprises (which, by consolidation thus

\footnotetext{
364 Fringe, because in most cases the solidarity component was not strong and was usually restricted to keeping tariffs as low as possible. But even that community orientated aim was in the context of, and subject to, running a successful business.
} 
includes the 38). All 26 donate support to their communities, often relatively (to the size of their communities) very sizable support. In the last year (2001/2) in which collective results were compiled, the 22 Licensing Trusts donated $\$ 18.9$ million. All four major case studies (chapters 5-8) gave evidence of these community enterprises actively benefiting their communities, as did the vignettes. Thus we can conclude that the community enterprises in the thesis pool all provided significant benefits to their communities.

But were these benefits such that they would have been received only through the existence of the community enterprise? By answering this we are better placed to respond to the 'necessary' and 'essential' question. Only with the ECCT at Eketahuna can we say that if it had not existed, the facilities and benefits it provided would not have happened. But even there a qualification should be made. It cannot be said that the lack of a supermarket and a fuel station would have occurred for all time. Private enterprise may have provided eventually, although the longer it did not, the greater was the risk that population exit would have increased the difficulty of viability.

With respect to the other community enterprises examined for this thesis, it is not possible to come to a categorical conclusion that the particular community enterprise was essential to enhancing the quality of life for that community. ${ }^{365}$ We can say that the community would be a different place without it, and that in many people's opinion that place would be poorer. In a number of circumstances even that would be contested. Examples are offered to clarify.

For example, is Taranaki a better place for the TSB Bank's operation? The impression was gathered during the course of the study that by far the majority of people would say it is. But consider the alternatives. If the TSB had decided not to go it alone in 1986 and followed the path of the other

\footnotetext{
365 For balance, it would be difficult to come to that conclusion about any organisation, private, religious,
} sporting or cultural. 
trustee banks in the next decade, what would be the outcome today? The TSB Community Trust would still be in existence and it still would have sizable funds to distribute, although arguably not as much as now. The Bank's branches would not exist, and in all probability would have been absorbed into the mergers that have occurred amongst the large banks. Thus, employment opportunities would be fewer. The particular trading emphasis that the TSB Bank gives, and which is highly appreciated by its customers, would not be available although it is likely that acceptable alternatives would be, however much they may be poorer in nature. The trading of the TSB Bank outside the region would not occur, thus eliminating the profits that are eventually returned to Taranaki. The prominent sponsorship of local events and activities would not be available but here again replacement would be likely to occur for the majority of cases, for that is the way of the commercial world. The conclusion that more comfortably fits from all this is that the TSB Bank is a very desirable organisation for Taranaki and materially benefits the region.

The ILT in Southland is virtually an icon of the region, deeply committed to enhancing its community. It has provided a wide range of trading facilities, some of which, for example, the Ascot Park Hotel, may not have been provided without its existence. Notably its neighbouring (and larger) city, Dunedin, has no hotel of Ascot's size and quality. Stadium Southland may not now exist, without which the Southern Sting netball franchise may not have achieved its remarkable success; the free fees scheme at the SIT and the indoor cycling velodrome now under construction may not have been possible without the ILT. But the ILT's critics would argue that it is a conservative trader that by its nature is not able to exercise the flair and variety of the private entrepreneur ${ }^{366}$; and since the majority of its community support donations come from gaming profits, if it were not in existence,

\footnotetext{
366 For balance, a great deal of competition does currently exist and that variety and flair is evident from both the ILT and private enterprise. Therefore, the community does appear to be have the best (and worse) of both worlds.
} 
private enterprise would distribute these funds. ${ }^{367}$ The ILT comes closer to the writer's sense of an essential organisation necessary to maintain and enhance the Invercargill way of life, but 'desirable' is a more comfortable assessment that is more likely to be accepted by the majority of local participants and observers.

At the other end of the effectiveness scale are the five Wellington Licensing Trusts that failed in the past decade - Porirua, Johnsonville, Terawhiti, Wellington South and Wainuiomata. All achieved notable successes for their communities at various times, and to varying degrees were enjoyed by community residents and visitors. But they failed in the end because they did not deliver consistent performance and the community majority grew tired of the regular controversies. As the community withdrew its support, economic failure followed.

The Trust House group of community enterprises (nine in all with four parents) based in Masterton is another on which to test the 'essential' versus 'desirable' assessments. Much the same case can fairly be said here as for the ILT. It is unlikely that the Solway Park Hotel would have been built by private enterprise interests. Without that, a significant proportion of the tourism and visitor numbers to the Wairarapa would not have happened. When the Government in 1998 was looking to divest housing assets to suitable community organisations, Trust House was the only such organisation nationwide of sufficient status and trading strength to be able to negotiate and complete a sizable sale ${ }^{368}$. The 541 houses purchased have since then become a valuable community asset delivering stability of access and profits back to the community. In that transaction it can fairly be stated that Trust House's status as a community enterprise was essential to its occurrence. The wide

\footnotetext{
367 But it would be unlikely that this would be done with the even handedness and disinterest (of personal interests) that currently exists.

368 Given the nature of the housing estate sold, the need to maintain its public good, and the politics associated with such a public asset, a sale to anyone other than a community owned organisation was politically unacceptable.
} 
range of businesses Trust House now operates in the lower North Island generate an excellent return, which is widely distributed to its communities. ${ }^{369}$ As with the ILT, critics would argue that the majority of profits distributed come from gaming and would be available to the community regardless of Trust House's existence ${ }^{370}$. But putting that issue aside for its limited validity, few would argue that these community enterprises have not been significantly beneficial to their communities and essential for their growth and quality of life. But it is still a difficult leap of faith to assert that the majority of Trust House's achievements would not have happened, or that some good alternatives would not have eventuated in the absence of community enterprise. Trust House's place in Wairarapa's development is perhaps best summarised as 'at times essential', 'always desirable' and 'significantly beneficial' to the community's quality of life.

That, then, is the overarching answer to the question posed in this section that the writer is most comfortable with after reviewing all the evidence contained in this thesis. Are community enterprises necessary to enhance the quality of life of a community? They are 'at times essential', 'always desirable' and 'significantly beneficial'. ${ }^{371}$

\subsubsection{SUMMATION}

The framework for community enterprises seeks to better define and explain why the concept has endured the philosophical swings, often radical and major, of not just decades but centuries. It is because they have endeared themselves to individuals and communities. Why they have endeared, and thus endured, is because of what they are - their component parts. Taken as a whole, community enterprises are a desirable amenity for any community.

\footnotetext{
369 \$5.7million profit was made in the 2005 financial year, a ROE of $22 \%$, of which $\$ 3.3$ million was distributed.

${ }^{370}$ For a fuller treatment of this issue, see chapter 6.

371 This assumes a (perhaps obvious) proviso: they must perform satisfactorily.
} 


\subsection{WHEN COMMUNITY ENTERPRISES ARE BEST ENGAGED}

It is now possible on the foundations of definition, practical experience and the case studies/vignettes to project the circumstances in which community enterprises are best employed. In doing so the context should be acknowledged. Community enterprises are a complementary institution to private enterprise, not a replacement. They can fill voids of need. They can enhance community life by operating businesses that do not seek to maximise economic performance. They can better balance the 'winner takes all' mentality that is one of the fundamental criticisms of the market economy. They can exhibit a fairness and concern for those less fortunate. But they should not seek to be what they are not: the dominant enterprise structure.

Examples of why a community enterprise may be formed can range widely:

- To generate profits that may support community activities.

In these circumstances the objective may be to generate funds that are available generally across sectors. The TSB Bank is an example today although when it was formed over 150 years ago it had different goals - thrift and investment funds availability. The Licensing Trusts may be placed in this category today although it can be argued that their original justification - to monitor the sale of sensitive products in the interests of the community's well-being - is still present but much muted by the open competitive environment that exists within their districts.

- To provide a service that private enterprise will not.

At times private enterprise will not provide a given service because it fears that the business of providing that service is not viable. Eketahuna is the classic small town example in which the 
community solved the problem of a missing service by combining a community enterprise and private enterprise. The community provided the facilities and subsidised the rent so that the operational risk was lessened.

Other examples are the large (relative to population and the then available markets) hotels constructed by various Licensing Trusts; for example, Invercargill, Ashburton and Masterton. These hotels were not profitable for a number of years and thus were subsidised by the Trusts' other trading operations. But their impact in increasing the economic activity within the community is notable.

- To help the poor or disadvantaged, or other subset of the community.

While this purpose may be seen as an extension of the first, it is separately defined to emphasise its prominence. Whereas the first category is more about general support for the enhancement of community life, here, a more fundamental and common reason for the establishment of community enterprises exists: to meet a particular need of concern to an individual or a group. Local Government is rarely well placed to meet such needs, and Central Government often finds it difficult to be sufficiently flexible to meet particular local needs.

An example is the establishment of the Masterton Trust Lands Trust in 1872. The Trust's prime purpose was and is the educational support of its defined community. The then Chairman of the Trust noted in his foreword to the Trust's history (Henderson, 1997): '...the ethic of the public good remains absolutely fundamental to the operations of the Trust.' 
An international example is the Farmers' market in Chaquicocha in the Peruvian Andes (Peredo, 2003). The need to find an outlet to sell the farmers' produce was met by a 'rather remarkable entrepreneurial undertaking that tacitly involved planning, investment, and risk taking on the part of the community.' The outcome was reduced poverty, 'stimulated markets and revitalized culture'.

- To provide a service in a more acceptable way to the community.

Conflicts can arise between an individual's desire to use a resource for personal gain and the needs and/or desires of a community. A resource may also operate to one person's or a small sector's advantage but not to the community majority's interests. Thus, the community may work to ensure that the common good predominates.

A modern example is the provision of high-speed internet access to outlying areas of a community at acceptable cost. Access at the centres of population may be economically viable but not so as the distance increases from the centres. While user-pay principles may still commonly prevail, some communities are saying that the common good is best served by evening out the costs.

In Mexico, community forest enterprises are a common way of addressing the conflicts that arise when personal livelihoods and communities are dependent on the sustainable management of forest resources. 'New studies are beginning to suggest that important gains in both social and economic justice, good forest management, and biodiversity protection are resulting from the actions of these community forest enterprises' (Bray, et al; 2003).

\section{- To ensure retention of important services or industries.}


A major employer, perhaps internationally owned, can cast a long shadow over a community. The greater the proportion of employment that such a firm provides relative to the rest of the community, the larger the firm's likely impact on local quality of life. One impact of globalisation is that decisions about an entity's future are often made away from the community on which they impact. Decisions to exit a community can in these circumstances be particularly painful as many rural communities experienced with the closure of meat processing plants in New Zealand during the 1990s. The loss of significant employment came close to devastating towns like Waitara and Patea.

Gates (1998) argues that in these and related circumstances communities should look to protect themselves. He provides challenges to share capitalism structures through such vehicles as community shareholding ownership stakes.

There are practical problems in pursuing many of Gates' suggestions and while these are not insurmountable, he is right in admonishing that caution is necessary and evolutionarily processes preferable.

Community enterprises are a vehicle to ease these impacts, although clearly with limitations. If an influential company already exists to supply a given need, then a community enterprise may seek to complement or establish a presence in another market sector. Establishing a new direction for a community may be easier for a community enterprise, because a community enterprise can take a longer term position than private enterprise which typically would prefer to fulfil a (profitable) market need.

Retention of important services may cover a very broad spectrum. For example health services or the retention of a doctor resident in 
the community may be subsidised or supported by the structure of a community enterprise; a number of examples of this exist in New Zealand, for example, the small community of Cheviot in the South Island provides incentives to better ensure a doctor is resident and working in the area.

- To create employment, reinvigorate a depressed area or enhance the economic development of a community.

Concerns may arise within a community on the limited opportunities for employment or the social impacts of an economic downturn in an area. Community enterprises can be a vehicle to address what private enterprise has little incentive to do. The Mondragon Corporacion Cooperativa ${ }^{372}$ centred in the Basque region of Spain is an exceptional international example of what can be achieved by an organisation dedicated to finding solutions to unemployment and depressed conditions.

\section{- To control or monitor a sensitive product.}

Community enterprises have been used in New Zealand to address concerns over a free market in alcohol and gaming. In the 1940s there was considerable trepidation that the freeing up of liquor licenses would cause a resurgence of the abuses prevalent at the turn of century when a number of communities had banned alcohol sales. Licensing Trusts were born out of those concerns. A good number of these Trusts today are popular supporters of their communities.

Gaming, in the form of poker machines, is a more recent occurrence (late 1980s) in New Zealand. While the primary vehicle

372 There are a good number of articles and books that tell of the Mondragon experience, for example see Whyte and Whyte (1988). 
for regulation has been the Gaming Acts, Licensing Trusts and Charitable Trusts have sometimes alleviated community concerns over the extremes of use. An example is the West Auckland Licensing Trusts who have restricted poker machines to a much lower density in their communities compared to other locations.

Community enterprises are an appropriate vehicle to monitor sales of sensitive products because the well-being of the community may take precedence over profit generation within the organisation's priorities.

\section{- To protect the community from abuse of a monopoly position.}

The trading of a scarce resource or in circumstances where it is practical for only one supplier to exist may justify the formation of a community enterprise. Profit maximisation may therefore become secondary to the common good of fair but not exorbitant pricing.

Examples are electricity (energy) and water (if it is traded). Electricity in New Zealand was predominantly community owned before the 1990s reforms and most communities sought only conservative returns. The advent of the market model brought notable increases in tariffs to a good number of communities but also significant profit taking on assets sales, as entities strove to achieve perceived and real economies of scale. While communities have benefited from the increased resources that fell to the investment trust style community trusts, payment of the inflated assets now falls to future generations of users. This is not to infer that one system was or is better than the other. A more detailed study than has been undertaken to date would be required before conclusions could be reached, and even those conclusions may 
require more time to elapse before they could be classed as anything other than tentative. There is, however, enough evidence to question whether all communities are better off under the market system.

\section{- To provide a community icon.}

Communities often benefit from events and community successes that generate community spirit and pride, for example Christmas parades, sporting successes and important anniversaries. They can become a focal point for a community who unite behind them. On a nationwide basis an example is the New Zealand All Blacks rugby team. In effect, the team and brand is owned by the clubs of New Zealand and the sporting and enterprise success is thus owned by the grass-roots of the country, the people of New Zealand.

Another internationally famous sporting icon is the Green Bay Packers. The Packers are owned by the community of fans who are limited in the number of shares they can own and for which they receive no dividends. They are the only franchise in the NFL owned in this manner. ${ }^{373}$

The icon need not be sporting related. Some communities have a reputation for the arts: Nelson for wearable arts and Mataura's Eastern Southland Gallery are two examples where the community has united behind notable galleries and events.

\section{- To satisfy a range of philosophical beliefs.}

A desire for local ownership and control (in commons), to build social capital, to balance the power and lessen the alienation of capitalism and to strengthen the stability of a community may

373 For more details on the uniqueness of the Packers see www.packers.com. 
individually or collectively provide enthusiasm to pursue the community enterprise model.

This category may be classed somewhat as a 'catch all' for those who philosophically believe that the concept offers benefits worthy of pursuit.

A desire for local ownership and control represents a reaction to the powerlessness that globalisation embodies for some, but certainly not all. The opportunities that flow from the internationalisation of markets are, to many, invigorating and inevitable. To others, they are a significant threat. It is suggested that both are right and that what is required are 'hard to find' and sometimes 'painfully gained' balances. 'Villages with boundaries' are as necessary and inevitable as the trends of globalisation. Only through defining and knowing our home will we be 'at home'. In these communities we are more likely to know and respect our neighbour, and that knowledge and respect will lessen the alienation of isolation.

The principle of balance is not an idealistic wish incapable of fruition. It is, instead, a pragmatic imperative articulated and endorsed by a number of authors quoted in this thesis. Just because the balances will be hard won and difficult to find should not make them any less desirable and necessary. The 'battles' that will be waged will be both international and local. They may be seen in the conflicts of free trade and the contentiousness of local politics. The outcomes are epitomised in the growth of the third sector and in globalisation.

Community enterprises are part of that world. 


\subsection{THE MOBILISATION OF COMMUNITIES}

Cohen's (1985:117) seminal finding that the assertion of community, at times the aggressive assertion, was inevitable in some communities, and just as inevitably not present in others, has particular importance for community enterprises. If the circumstances where and when one of these two possibilities will occur can be better defined then the occasions for success and failure will be better known. Answering the latter possibility is compelling. If the chances of failure are high or higher than acceptable alternatives, then why waste resources?

This question arose many times during the study: why (in Eketahuna, Taranaki, Invercargill, West Auckland, Masterton...) was there such community spirit that the success of their community enterprise was much assisted? Cohen (:104) noted that 'the answer has not often been attempted in respect of local communities' and his solutions have a large degree of speculation: But he provides an answer in some depth to the question: 'Why do communities respond assertively to encroachment upon their boundaries? They do so because their members feel themselves to be under so severe a threat from some extrinsic source that if they do not speak out now they may be silenced for ever. Further, they do so because their members recognise their own voices within them, and because they feel the message of this vocal assemblage, though general, to be informed directly by their own experiences and mentalities. And they do so because their members find their own identities as individuals through their occupancy of the community's social space: if outsiders trespass in that space, then its occupants' own sense of self is felt to be debased and defaced.' (:109)

Much of this extended quotation is about challenge and defence. 'Encroachment', 'threat', 'trespass', 'debased' and 'defaced' are aggressive words that reflect an almost negative or reactionary component. But included in the statement are also the achievements, the positive response to the slow or radical death that is inherent in change. The recognition of 'their own voices' and finding 'their own identities' represent James' (1961) spiritual transformation 
when people see in the challenge or change opportunities for their own growth. It is these two themes that this thesis seeks to extend in the context of the case studies and vignettes and in connection with all four of the components of the framework.

It is an interesting and possibly important question as to which comes first, the challenge or the individual desire to contribute. Do communities need to be 'threatened' before mobilisation will occur? Or is there an ongoing search for vehicles to enhance a community? The question has relevance to an assessment of the degree to which communities can anticipate issues and address them proactively before they become crisis, or is a crisis necessary before the essential resources become available?

The case studies showed that some people are almost always seeking to contribute - it is 'what they are' and important to their 'sense of self' to do so. Practical experience and reason supports this. Such individuals are present in most communities, but only when their voices are sufficiently strong and credible, which in itself is a function of the receptivity of the community, can sufficient momentum be built to pursue opportunities effectively.

This component of community leadership was a significant factor in all four case studies and frequently present in the vignettes. On some occasions the leaders reacted to challenges and in others they sought them. In Eketahuna the crisis was there to be addressed and the leaders stepped up, providing solutions which in large part were readily accepted because of their credibility. But notably also in Eketahuna, two major achievements were not crisis; the success of the schoolgirls cricket team and the ongoing ( 3 years in a row) winning of the regional rugby premiership. In West Auckland the aggressive driving leadership of the General Manager was pivotal to the final outcome. For the TSB's decision to go it alone in 1986, leadership was again crucial; here the Mayor, local Member of Parliament and bank management were the key players in the team that made it happen. And in the ILT, the General 
Manager and the previous President's dedication to enhancing the ILT and Invercargill are far beyond what would normally be expected for these positions.

The idea that outstanding leadership is an important factor in success is not new. But Cohen talks of community voices as a generality rather than emphasising specific attributes. The question to consider is: would the results be the same without these outstanding people? The writer's answer would be, no, they would fall far short of what was achieved. But then, would another exceptional leader step up?

Acceptable and credible leadership amongst the community voices is thus a pre-requisite for achievement of the defined goals of community enterprises. If that leadership is not present it is difficult to conceive of circumstances in which crisis can be overcome or opportunities successfully pursued.

The immediacy of a crisis creates momentum. A feature of the case studies was the 'life cycles' experienced. There were periods of (great) success followed by drifting or worse. The election of a strong leader to arrest ILT's indifferent progress during the early part of the 1990s was noted during the interviews. The ECCT's successes have been quite limited apart from the two occasions they have met the need for essential services. In the writer's experience 'life cycles' of achievement are frequently prevalent in enterprises, and often more common than perhaps thought, even when the leadership is consistent during these periods. This gives more substance to the view that crises or threats are significant motivators to momentum. But as practical reason and the 'other everyday' successes of the case study entities exhibit (for example, the long term, ongoing success of the TSB Bank), crisis and threats are not intrinsic.

An answer to the question - why is there a strong community spirit in some communities and not in others - posed at the beginning of this section may now be answered, at least partially. When asked this question the response of 
the community leader being interviewed was inevitably 'I don't know' or 'I'm not sure'. Interviewees often followed this general answer with a variety of suppositions that were variable in nature but with some generic components. ${ }^{374}$

The Eketahuna community, for example, mobilised to meet the need for essential services. The challenge was a specific and easily understood threat to their way of life. Do nothing was not an option because they needed ready access to food and fuel. In West Auckland the threat was to the stability of their community enterprises. More competition in the nature of the supermarkets would threaten the viability of 'their' organisations and put at (perceived) risk the considerable funds that were being distributed to many community organisations. There was also another powerful challenge. They were being told by the supermarkets, perceived to be 'global predators' by a significant number, that they were being treated differently than the rest of Auckland and New Zealand. They were different. They took pride in being different. To be told they should not be different went to the very core of their community pride. Perhaps it was inadvertent, but the supermarkets' challenge was an aggressive affront that had to be rejected. ${ }^{375}$ For the Taranaki community the threat was the loss of their Bank, a Taranaki icon. Here, it can not be said that the community mobilised to meet the threat. Indeed, their response was quite muted. It may be that they had confidence in the community leaders working on their behalf but it requires somewhat of a leap of faith to assert that. It can be said there was very limited opposition from the community to going it alone. And in Invercargill, the possibility of a poll at anytime is the 'threat card' that the ILT can and does play to mobilise support. A challenge by the supermarkets would be a direct affront to a Southlander's independence. In effect, the supermarkets would be 'stealing' Southland assets. The likely reaction against the supermarkets is one

\footnotetext{
${ }^{374}$ Refer to chapter 9 for the analysis of these components and their presence in the case studies.

375 There were other influences and for the sake of balance the case study should be read in its entirety.
} 
component discouraging them from a competition poll challenge ${ }^{376}$ in that region.

In all four studies there were threats of varying intensity to meet. The themes that emerge are a reaction to those threats: 'it is ours'; 'we are different'; 'we need to protect the advantage, facilities or resources we have'. We can see overtones of Cohen's sense of disadvantage or subordination, his 'to be or not to be', the 'nothing more to lose' and the 'them versus us' mentality. But the community mobilisation is more than 'merely' a reaction to a threat. It is intensely defining who they are: their own identities as individuals. To be a New Zealander is 'merely' to differentiate us from other nations. To be a Southlander, a Westie, from Eketahuna or Taranaki is to come closer to defining the whole person. The community enterprises studied herein provide part of that personal definition of self.

Like Cohen we are left to speculate why some communities do not appear to have a strong sense of community spirit. Perhaps such spirit is dormant in these communities, waiting for the 'right' threat or challenge; perhaps the necessary leadership is not available at the pivotal time; perhaps the community voices are not sufficiently developed; perhaps there are other alternatives for the community to 'rally' around that define and satisfy; perhaps the community is inflicted by excesses, either too much or too little sustained by welfare dependency; perhaps ... we do not know or can not know fully.

\subsection{COMMUNITY OWNERSHIP}

Ownership is a curious phenomenon for community enterprises. It cannot be viewed exclusively through the lens of private enterprise with its neat and scripted titles that provide bounded certainty. What needs to be established is a new paradigm.

376 Again, for the sake of balance, a number of statements in this paragraph should be qualified. For that, 
McKinlay's (1999) answers to what he calls these 'ownerless' ${ }^{377}$ assets are not convincing. He fails to address the different forms in which ownership is manifested, but in debating the issues he properly raises issues of significance. Perhaps it can be said that when he wrote the text, the privatisation era, while waning in New Zealand and much of the Western world, still clouded the public ownership horizon.

Privatisation is predicated on economic efficiency ${ }^{378}$ which is often linked to share ownership and market disciplines. Given the successes of privatisation, (see note 46) it is not surprising that during its dominant years ${ }^{379}$ much of the public policy relating to trading enterprises had a 'private ownership' emphasis. Private ownership also has the compelling attraction of being 'tidy' and 'certain' with respect to who are the financial owners.

It is when we enter the other worlds of ownership that, often, there can be an uncomfortable uncertainty, for example, does a community that provides the resources for a business to operate at a profit, have an (non-financial) ownership stake in that organisation? Jensen and Meckling (1994) are correct when they tell us that people care about many things. We frequently care deeply, be it for families, a point of view or honour, community life, a state of existence or a way of life - the opportunities and possibilities are truly endless. It is but a short step, but sometimes hard to take, to commitment. Involvement follows commitment. Ownership predicated on commitment, which may be for a belief and does not need to be an action, is a powerful

\footnotetext{
refer to the full case studies.

377 His publication (Public Ownership and the Community) addresses ownership in the specific context of the Community Trusts of New Zealand who hold sizable assets (then $\$ 5$ billion) and are a recent creation (late 1980s and 1990s).

378 The privatisation goals were wider than economic efficiency although that dominated. Megginson and Netter (2001) record Price Waterhouse's (1989) summary that (1) to raise revenue for the state, (2) to promote wider share ownership, (3) to reduce government interference in the economy, (4) to promote wider share ownership, (5) to provide the opportunity to introduce competition, (6) to subject SOEs to market discipline and (7) to develop the national capital market were the goals adopted by 'almost every government' that pursued privatisation policies.

379 The early 1980 s to the late 1990 s.
} 
concept. It may be manifested in a desire to achieve success in a certain field, say a sport. Personal and individual achievement is but one possibility. It may be for the success of a team or club. Indeed, the club style of ownership gives insights into the ownership of community enterprises. There are (almost always) no titles or ownership script for a club. There may be a subscription receipt. But it would take a brave or foolhardy person to say to a committed club member that they do not 'own' the club in the sense that it is 'their' club.

The ownership of community enterprises is not as 'certain' as private enterprise. But that does not make it any less real. The depth of commitment and ownership by the communities in the four case studies is very notable and quite real. It will ebb and flow. At times it may be full of sound and fury, a turbulent river seemingly out of control. But there are banks or boundaries somewhere even if for the moment we cannot see them. At times it will quietly meander, seemingly deep and lazy, and content to ease along.

There need to be boundaries defining a community enterprise and its purpose and form(s). Structures of accountability and governance are critical to success. Where these are weak, problems will inevitably occur. Where management is not adequately questioned and allowed too free a rein, where Boards are arrogant or uncaring of their communities or where community enterprises' boundaries are ill-defined and controls weak, problems will occur. When they start to surface it is often the 'system' or concept of ownership that is railed against. Instead, the problem is almost always procedural and/or performance related.

This thesis concludes that the structure of community ownership is not inherently flawed because it lacks the tightly scripted certainty of private ownership. But, like its counterpart, it requires good governance and accountability mechanisms. 


\subsection{MIXED GOALS}

A corollary to the key thesis in this research is the issue of whether it is wise to mix the performance of economic goals with social and community support goals. It is somewhat of a sideshow. There was some interest in the topic in the 1980s when it was generally (but not universally) considered that it was best to employ different bodies for diverse goals so that conflicts of emphasis may be better managed. In this way, so the theory maintained, the goals were more likely to be successfully achieved. This view may have shaped New Zealand's State-Owned Enterprises Act (1986) and the Energy Companies Act (1992), both of which required entities formed under the legislation to be successful businesses first. Certainly there was a climate during the 1990s that favoured separation of economic and social goals for public bodies.

There is a certain logic to such separation. Social and community support goals often require different skills and mindsets from business performance. But, frequently, performance results from emphasis and application. As Jensen and Meckling (1994) eloquently explain in their seminal article, we care about many things and 'comfortably' pursue a range of interests and goals. So also may an organisation and there is everyday evidence that this occurs. The key issue is the degree of resources brought to the goals. Social and community support goals are often harder to define than business goals and sometimes that lack of clarity can be debilitating.

The research found community enterprises in New Zealand employ a number of approaches to mixing of goals. Some (ILT, ECCT, Tararua Foundation, Masterton Trust Lands Trust) competently pursued mixed goals under one administration; others (Flaxmere Licensing Trust, Rimutaka Licensing Trust, and their subsidiary charitable trusts) used different legal entities but were in effect one and same; and still others (Masterton Licensing Trust, Trust House Limited, Portage and Waitakere Licensing Trusts, TSB Bank and TSB 
Community Trust) had separated the functions out and placed responsibility for each under different bodies.

The logic to these different approaches is that the circumstances suggest or dictate the approach. Given all the applicable pressures, the organisation decides what best meets their needs. Fine tuning is constantly required but the institutional wisdom (most often) readily copes.

\subsection{INFILTRATION OF POLITICS}

This too is more a sideshow than the core of the thesis. But because it is a 'backroom' ${ }^{380}$ distraction it is summarily addressed.

A not infrequent criticism of elected or public bodies is that politics debilitates performance. The inference is that diverse and often private agendas divert emotions and energies away from the optimal performance of the organisation. Another common 'backroom' criticism is that often the ballot box does not necessarily deliver the competency skills required to satisfactorily govern.

There is some truth to these criticisms as captured by newspaper ${ }^{381}$ coverage of the conflicts that have arisen from time to time. In the writer's experience selfish and self-promoting agendas are occasionally ${ }^{382}$ pursued, and inadequate management and governance skills can stunt an organisation's performance. But politics, again in the writer's experience, also has a remarkable ability to compensate. The issues eventually get sorted. If an elected representative pursues an interest, say for private benefit, then

\footnotetext{
380 That is, it is not uncommon among management and policy advisors to criticise the machinations of politics.

381 For example, the series of stories and editorials surrounding the failure of the five Wellington Licensing Trusts in the mid to late 1990s. But contest and conflict at both local and national government level are a common experience throughout the country and regularly featured in local and national papers.

382 The word occasionally is deliberatively chosen. By the frequency of comment in the media the temptation is to believe that self-serving purpose is the norm. But such conflict is but a small percentage of the actual work and decisions of the bodies being commented on.
} 
exposure in the media provides a balance. If an institution is under-skilled in governance, then provided it occupies a position of some importance, communities most often compensate by ensuring people of skill become available.

There was no evidence that politics debilitates the performance of the community enterprises in chapters $5-8$, nor in the vignettes in chapter 2 . Conflicts and tension frequently existed. The Case of the West Auckland Licensing Trusts (see section 2.2.2) examples the type of tension that can exist, and yet practical reason and the desire to progress the issues won out.

\subsection{THE KEY THESIS QUESTION: ARE COMMUNITY ENTERPRISES VALUED?}

This thesis' pivotal conclusion that community enterprises are (most often) valued by their communities, and are a valuable form of institution in today's world order, is supported by the following evidence:

- The case studies (chapters5-8) and the vignettes offer credibility to community enterprises' ability to perform. A good number of the cases exhibit outstanding performance. A sceptic may say that case selection is weighted to the successful. While this argument may have some validity for the four in-depth studies, ${ }^{383}$ it has limited validity when compared to the wider field ${ }^{384}$ to which this research refers.

- The case studies' and the vignettes' evidential stories, in the mould of Toulmin's (1990) 'rich perspective of buman affairs', present a strong picture of 'valued institutional status' for the community enterprises in those case studies.

\footnotetext{
383 But note the justification provided in section 4.4.1.

384 That is, the 38 community enterprises and the 26 energy trusts (see section 10.1.4).
} 
- Legislation and support similar to that provided by the British Government, the OECD and a number of European Governments highlight the renaissance of community enterprises internationally.

- The growth of third sector organisations worldwide, with their civil-solidarity base emphasis, highlights unique phenomena that seek to balance adverse trends of globalisation and market forces.

- During most, if not all, of the 1990s, community enterprises were on the defensive often being forced to protect their existence, as in the case of the New Zealand energy trusts and licensing trusts ${ }^{385}$. Celebration of their achievements was almost non-existent. There are some signs that this defensiveness may be changing; for example, the status of the TSB Bank, Invercargill Licensing Trust and Trust House Limited today, and the fact that further privatisation is not on the present Government's agenda.

- Section 10.2 suggests community enterprises may usefully be engaged under a wide range of circumstances.

- The research herein indicates that community enterprises have characteristics that endear them to their communities, provided they perform satisfactorily and reasonably meet the community's expectations.

This writer's experiences with community enterprises have been clearly presented. The belief driving the thesis - that they are a good concept - is even stronger in the writer's mind at the end of this project than it was at the beginning, when the belief was largely based on practice. Better understanding of what they are has lessened the conundrums. International trends and

\footnotetext{
385 The probable exception here would be those formed under the charitable trusts legislation. These would not be as sensitive to the political climate, depending more on 'private' initiatives.
} 
examples have broadened a previously more limited knowledge of when and where these organisational forms may be engaged. What has not changed is the statement of limitations. Community enterprises are not for every circumstance. They should not seek to displace the prevailing institution, private enterprise. They should seek to complement, and to do what capitalism cannot, or will not do.

\subsection{IMPLICATIONS FOR THEORY, POLICY AND PRACTICE}

The New Zealand Government could encourage community enterprises through relatively simple policy changes. The United Kingdom 2002 policy toward social enterprises did not require legislation although laws establishing the community interest companies were passed in 2005. Arguably, a document like that would help establish a more receptive climate in New Zealand toward community enterprises. However, it is doubtful that new legislation would achieve anything that is not achieved by the present Charitable Trusts Act, as the Eketahuna community found.

Financing the establishment of community enterprises is an issue that policy could beneficially address. Eketahuna found a solution to its problem, but not without canvassing, and rejecting, a number of other possibilities. The Licensing Trusts in New Zealand found lack of initial capital to be the biggest hurdle to overcome on getting established, and it was not surprising that some never did overcome it. A more receptive climate could be achieved firstly by officially recognising community enterprises as worthy forms of organisations in many circumstances.

It would be important to precisely define community enterprises in New Zealand. The debacles and humiliations that arose from the community initiatives fund ${ }^{386}$ would need to be put aside with explanations that present community enterprises as a very different concept from those initiatives.

386 See the web-site www.familyservices.govt.nz (Ministry of Social Development). 
There needs to be a much better data base and statistical analysis (for example, their generic types, their purposes, and their assets) of charitable trusts in New Zealand. While these shortfalls are apparently being addressed, it is long overdue.

Research similar to Salamon's (2003) projects now rippling through many countries would beneficially better define the third sector in New Zealand, and it appears this may be beginning to happen, for example, in the Local Partnerships and Governance project (see web-site www.arts.auckland.ac.nz).

Detailed research on community enterprise failures would offer different insights and perspectives. The failure of five licensing trusts in Wellington has the fascinating potential to address causes that appear to be based on debilitating politics, incompetence and personal agendas. Whether there were deeper systemic causes of failure would be an important question to examine.

The components that comprise the 'whole' that are community enterprises would benefit from research that pursued different perspectives. That the writer is an advocate should be clear by now. A sceptic may highlight other weaknesses (although 30 years of practical living should surely have brought most to light) and other policy perspectives, such as greater corporate social responsibility over encouragement of community enterprises.

The richness that is community will always be a fascinating voyage of discovery. Cohen's work on the symbolic construction of community deserves extension. To better understand why some communities react so strongly to challenges and others do not is especially worthy of further research. For example, why did the Taranaki community 'save' their bank in 1986 and not their energy company in 2004? On the face of it, the results are a contradiction. Deeper research into this and other experiences with community enterprises will help us better understand the qualities of these institutions that are enjoyed, and even more importantly, those that communities say are essential. 


\section{AND FINALLY....THE CONCLUSION}

The search to know community enterprises for the first time (T.S.Eliot) has been fascinating. Like the early settlers to New Zealand, and significant numbers of New Zealanders over the years since then, the writer believes that the concept offers much to the mix of institutions that comprise the mythical ideal society.

Every community should have one! $!^{387}$

387 And one final footnote. If this statement seems contradicted by a previous assertion that community enterprises are not for every circumstance and for every community, the reader will have to picture the ideal community.. 


\section{BIBLIOGRAPHY}

Anderson, Charles W. (1990)

Pragmatic Liberalism. The

University of Chicago Press:

Chicago.

Andranovich, Greg and Nicholas P.Lovrich (1996) Communityorientated Research: Grassroots Issues versus National Policy Agendas. American Behavioral Scientist, March-April: vol. 39.

Arrow, Kenneth J. (1992) I Know a Hawk from a Handsaw. In M.Szenberg, ed., Eminent Economists: Their Life and Philosophies. Cambridge University Press: Cambridge and New York.

Ashworth, P.D. (1997) The variety of qualitative research. Part two: Nonpositivist approaches. Nursing Education Today. Jun; 17 (3): 219-24.

Audit Office, The (2000) A Digest of Local Authorities and their ownership of other entities. The Audit Office: Wellington.

Bank of England (2003) The Financing of Social Enterprises: A Special Report. www.bankofengland.co.uk

Barber, B. (1984) Strong Democracy. University of California Press: Berkeley, CA.

Barry, Norman P. (2000) Do Corporations have any Responsibility Beyond making a Profit? Markets \& Morality, Acton Institute, vol. 3, no.1.

Barry, Norman P. (1997) Business, Ethics and the Modern Economy.
The Sir Ronald Trotter Lecture, New Zealand Business

Roundtable.

Barry, Phil (2002) The Changing Balance between the Public and Private Sectors. New Zealand Business Roundtable.

Baum, Gregory (1989) Liberal Capitalism in The Logic of Solidarity. Orbis Books: New York.

benShea, Noah (1989) Jacob the Baker: Gentle Wisdom for a Complicated World. Villard Books: New York.

Bentley, Colene (2003) The New Liberalism: Reconciling Liberty and Community. Victorian Studies, 46.1, p147(3).

Berger, Bennett M. (1998) Disenchanting the concept of community. Society, vol.35, no. 2.

Bernstein, Peter L. (1996) Against the Gods The remarkable Story of Risk. John Wiley \& Sons: New York.

Bilgrien, Marie Vianney, (1999) Solidarity: A Principle, An Attitude, $A$ Duty? Or the Virtue for an Interdependent World? American University Studies, Lang: New York.

Binder, Guyora (1993) The End of History and the Last Man. Michigan Law Review, May.

Birdsall, Nancy and John Nellis (2002) Winners and Losers: Assessing the distributional impact of privatization. Center for Global 
Development, working paper number 6.

Blackwell, Lord (2001) Towards Smaller Government: The Second Wave of the Revolution. Centre for Policy Studies Annual Lecture, London.

Bollier, David (2002) Commons sense: Community ownership and the displacement of corporate control. Multinational Monitor, Washington: Jul/Aug.

Bollier, David (1997) Aiming Higher. Amacom: New York.

Bollinger, Conrad (1967) Grog's Own Country: the story of liquor licensing in New Zealand. Minerva: Auckland.

Bordo, Michael D., Barry Eichengreen, and Douglas A. Irwin (1999) Is Globalization Today Really Different than Globalization a Hundred Years Ago? Working Paper 7195, National Bureau of Economic Research: Cambridge, MA.

Boyd, Graham (2003) Community enterprise Companies on www.caledonia.org.uk.

Bray, D.B. et al (2003) Mexico's Community-Managed Forests as a Global Model for Sustainable Landscapes. Conservation Biology, June, v17.

Brennan, Michael (1994) Incentives, Rationality and Society. Journal of Applied Corporate Finance, (September).

Brundtland, Gro Harlem (1994) What is World Prosperity? Stockton Lectures. Business Strategy Review, Summer, v.5 n2.
Carothers, Thomas (1999) Civil Society. Foreign Policy, Winter, p.18.

Clark, Helen (2002) Prime Minister's address to the London School of Economics. On web-site www.beehive.govt.nz.

Cohen, Anthony P. (1982) Belonging: identity and social organization in British rural cultures. Manchester University Press: Manchester.

Cohen, Anthony P. (1985) The Symbolic Construction of Community. Tavistock: London. Last reprinted 2000.

Collins, James C. and Jerry I. Porras (1996) Building your Company's Vision. Harvard Business Review, September-October.

Collins, James C. and Jerry I. Porras (1994) Built to Last: successful habits of visionary companies. Harper Business: New York.

Cuomo, Mario M. (1985) Your One Life Can Make a Difference. Speech delivered at Harvard Class Day, Cambridge Massachusetts, June 5. Vital Speeches of the Day.

Curtis, Bruce (2003) Third Way Partnerships, neo-liberalism and social capital in New Zealand. Research paper number 4, Local Partnerships and Governance Research Group, University of Auckland.

Daniels, Michael (2001) Maslow's Concept of Self-Actualization. On web-site http://www.mdani.demon.co.uk.

DeLeon, Peter (1998) Models of policy discourse: insights versus prediction. 
Policy Studies Journal, Spring: v26.

Denzin, N. (1989) Interpretive Interactionism. Sage :Newbury Park, CA.

Department of Trade and Industry (UK) (2002) Social Enterprises: a strategy for success on www.dti.gov.uk.

de Tocqueville, Alexis (1969) Democracy in America. Ed. J.P.Mayer, trans. George Lawrence. Doubleday: New York.

Drucker, Peter F. (1998) Civilising the City, Introduction to the Community of the Future. The Drucker Foundation.

Drucker, Perter F. (1980) Managing in Turbulent Times. Harper and Row: New York.

Drucker, Peter F. (1969) The Age of Discontinuity. Heinemann: London.

ECOTEC Research and Consulting Limited (2003) Guidance on Mapping Social Enterprise. Final Report to the DTI Social Enterprise Unit. Web-site www.ecotec.com.

Edelman, Ira (2000) The Riddle of Community-Based Initiatives. National Civic Review, summer, vol.89.

Eisenhardt, Kathleen (1991) Better Stories and Better Constructs: The Case for Rigor and Comparative Logic. Academy of Management Review: vol 16, no.3.

Eketahuna Case Study References:

- Adcock, Irene. (1973) A goodly beritage; Eketahuna and districts 100 years 1873-1973.
Eketahuna Borough and County Council.

- Best, Peter. (2001). Eketahuna: stories from small town New Zealand. Wairarapa Archive, Masterton.

- Bush Telegraph Archives in Pahiatua.

- ECCT annual accounts 19892003.

- Garson, (2001). Case study research in public administration and public policy. North Carolina State University.

- Wairarapa Times Age archives in Masterton.

- Walsh, John C. and Steven High. (1999). Retbinking the Concept of Community. University of Ottawa Press, November.

Ellsberg, Robert (1989)

Introduction to The Logic of Solidarity. Orbis: New York.

Emmott, Bill (2003) Saving capitalism from the capitalists. $12^{\text {th }}$ annual Hayek Memorial Lecture on www.iea.org.uk.

Encyclical letter of John Paul II (1987) Sollicitudo Rei Socialis as contained in The Logic of Solidarity. Orbis: New York.

Engster, Daniel, (2005) Retbinking care theory: the practice of caring and the obligation to care. Hypatia, Summer.

Epstein, R. (1995) Simple Rules for a Complex World. Harvard University Press: Cambridge, Mass. 
Epstein, Richard (1998) Principles for a Free Society: Reconciling Individual Liberty with the Common Good. Bradley Lecture Series, American Enterprise Institute.

Eur-Lex on Web-site europa.eu.int/eurlex/en/about/abc/abc_07.html

Evers, Adalbert and Jean-Louis Laville (2004) The Third Sector in Europe. Elgar: Cheltenham, UK.

Fischer, Frank (1995) Evaluation of Public Policy. NelsonHall:Chicago.

Fischer, Frank (1998) Beyond Empiricism: Policy Inquiry in Postpositivist Perspective. Policy Studies Journal, Spring.

Fischer, Frank (2003) Reframing Public Policy. Oxford University Press:Oxford.

Fisher, Berenice, and Joan Tronto (1990) Towards a feminist theory of care. In circles of care: Work and identity in women's lives. Ed. Emily Abel and Margaret Nelson. State University of New York Press: Albany.

Fisher, Julie (2003) Local and Global: International Governance and Civil Society. Journal of International Affairs, Fall, v57 19-.

Flaxmere Licensing Trust case references:

- Discussion with James Morgan, Ken Kibblewhite and John Bradshaw;

- Annual accounts of the Trust 1987-2005;

- Correspondence files housed at Trust House Limited in Masterton;
- 25 year anniversary booklet.

- Newspaper clippings on Flaxmere files.

Forester, J. (1993) The Argumentative Turn in Policy Analysis and Planning. Duke University Press: Durham.

Fowler, Robert Booth (1991) The Dance with Community. University Press of Kansas.

Friedman M. (1970) The Social Responsibitity of Business to Increase its Profits. The Sunday Times Magazine, 13 September.

Fukuyama, Francis (1992) The End of History and the Last Man. Free Press: New York.

Fukuyama, Francis (1995) Trust: the social virtues and the creation of prosperity. Free Press: New York.

Fukuyama, Francis (2000) Social Capital and Civil Society. IMF Working Paper, IMF Institute.

Gardner, David P. (1984) The Humanities and the Fine Arts. Speech delivered at the University of Utah, May 31.Vital Speeches.

Gates, Jeff (1998) The Ownership Solution: Toward a Shared Capitalism for the Twenty-First Century. Perseus: Mass.

Geertz, C. (1973) Interpretations of Cultures. Basic Books: New York.

Gewirth, Alan (1996) The Community of Rights. University of Chicago Press: Chicago.

Gewirth, Alan (1998) Self-fulfillment. Princeton University Press: Princeton, New Jersey. 
Giddens, Anthony (2001) The global third way debate. Polity Press: Malden, Mass.

Giddens, Anthony (1999) Globalisation: The Runaway World. Lecture 1, BBC Reith Lecture.

Giddings, Lynne S. and Barbara M. Grant (2007) A Trojan Horse for Positivism? A Critique of Mixed Methods Research. Advances in Nursing Science, vol. 30, no.1, 52-60.

Goffman, E. (1974) Frame Analysis: An essay on the organization of experience. Harvard University Press: Cambridge, Mass.

Gronbacher, Gregory M.A. (2002) The Humane Economy. Acton Institute on www.acton.org.

Hajer, M. (1995) The Politics of Environmental Discourse. Oxford University Press: Oxford.

Hanifan, Lyda Judson (1916) The Rural School Community Center. Annals of the American Academy of Political and Social Science, 67.

Harvey, Bob (2004) Westies: up front, out there. Exisle Pub.: Auckland.

Hayek, F.A. first printed Yale University Press, New Haven, (1951) The Moral Imperative of the Market. This edition reprinted by New York University Press, 1985.

Henderson, Alan (1997) Fortuitous Legacy. Masterton Trust Lands Trust.

Hillery, George A. (1955) Definitions of Community: Areas of Agreement. Rural Sociology 20.
Hofferbert, Richard (1990) The

Reach and Grasp of Policy Analysis. University of Alabama Press: Tuscaloosa.

Hollenbach, David (1997) The Market and Ethics. Concilium, number 2, 67-76.

Imbroscio, David; Williamson, Thad; and Alperovitz, Gar (2003) Local policy responses to globalization: place-based ownership models of economic enterprise. Policy Studies Journal, Feb.

International Monetary Fund Issues Brief, (2000, corrected 2002)

Globalization: Threat or Opportunity? IMF web-site, www.imf.org.

ILT Case Study references:

- Bissinger, Buzz (1997) A Prayer for the City. Random House, New York.

- De La Mare, Alan (1981) Drink or Drought: Liquor Licensing and the Probibition Movement. Craigs, Invercargill.

- Hansard Parliamentary Debates (1944), pages $17,40,55$, $650,716,718,719,745,747$, 748, 753, 754, 765, 837, 853.

- Infometrics Consulting (2002) Economic Impact on Invercargill of SIT's Zero Fees Policy. A report to the Southern Institute of Technology.

- Invercargill Licensing Trust Annual Reports and financial statements 19452004. 
- Invercargill Licensing Trust Charitable Trust financial statements 1995-2004.

- Invercargill Licensing Trust Sports Foundation financial statements 1995-2004.

- Invercargill Licensing Trust Minutes.

- Invercargill Licensing Trust press clippings files.

- Lind, Clive A. (1994) Pubs, Pints and People: 50 years of the Invercargill Licensing Trust. Craigs, Invercargill.

- Prendergast, John (2004) The Southland ExperienceAddressing Regional Issues. Address to the Philanthropy NZ conference, Wellington, November.

- Putnam, Robert (1993) Making Democracy Work: Civic Traditions in Modern Italy. Princeton University Press, N.J.

- Sale of Liquor Act 1989.

- The Southland Times: various articles including $27 \mathrm{March}$ 2000, 21 October 2000, 18 October 2001, 31 October 2001, 1 November 2001, 20 July 2002, 5 September 2002, 25 September 2002, 20 November 2002, 13 May 2003, 30 August 2003, 16 March 2004, 5 June 2004, 16 March 2004, 1 July 2004, 9 October 2004, 16 October 2004, 3 March 2005, 9 May 2005.
- Statistics New Zealand on website www.stats.govt.nz.

- WITT (Western Institute of Technology at Taranaki) annual report 2003.

- Web-sites:

- www.ilt.co.nz (Invercargill Licensing Trust)

- www.icc.govt.nz (Invercargill City Council)

- www.sit.ac.nz (Southland Institute of Technology)

- www.comtrustsouth.org.nz (Community Trust of Southland)

- www.dia.govt.nz (Department of Internal Affairs)

- www.gamblingwatch.org.nz (Gambling Watch , Hamilton New Zealand)

James, William (1961) Psychology: the briefer course. Originally published by Harper: New York,

Jensen, Michael C. and William H. Meckling (1994) The Nature of Man. Journal of Applied Corporate Finance, Summer, vol. 7, no.2. Revised July 1997.

Jensen, Michael C. and William H. Meckling (1976) Theory of the Firm: Managerial Behavior, Agency Costs and Ownership Structure. Journal of Financial Economics 3, no.4 (October).

Jensen, Michael C. (1994) SelfInterest, Altruism, Incentives \& Agency Theory. Journal of Applied Corporate Finance, vol. vii, no.2 (summer). 
John Paul II, (1994) Crossing the Threshold of Hope. Knopf: New York.

John Paul II (1987) Sollicitudo Rei Socialis. Papal Encyclical.

John Paul II (1991) Centesimus Annus. Papal encyclical.

Kaplan, A. (1964) The conduct of inquiry: methodological for behavioral science. Chandler Publishing: San Francisco.

Kaplan. T.J. (1993) Reading policy narratives: beginnings, middles, and ends. In Fischer F. and Forester J. (eds.) The argumentative turn in policy analysis and planning. Duke University Press: Durham.

Korten, David C. (1995) When Corporations Rule the World. Kumarian Press and BerrettKoehler. (A summary article on google titled Markets are for People.)

Kelsey, Jane (1995) The New Zealand Experiment: $A$ World Model for Structural Adjustment? Auckland University Press: Auckland.

Kelsey, Jane (2002) At the Crossroads: three essays. Bridget Williams Books: Wellington.

Kerr, Roger (1996) The Meaning of Corporate Social Responsibility. Address to the AISEC Seminar.

King, G., Koehane, R.O., and Verba, S. (1994) Designing Social Inquiry: Scientific Inference in Qualitative Research. Princeton University Press: Princeton.

Kramer, Ralph M. (2004) Alternative paradigms for the mixed economy: will sector matter? Chapter 11 in The
Third Sector in Europe. Elgar:

Cheltenham, UK.

Kulkarni, G.R. (1979) Management

Problems in the Public Sector.

Economic and Political Weekly, Vol. 15, no.9.

Kuttner, Robert (1997) The Limits of Markets. American Prospect.

No.31, 28-41.

Ladd, Everett Carll (1998) Bowling with Tocqueville: Civic Engagement and Social Capital. Bradley Lecture Series, American Enterprise Institute for Public Policy Research.

Larner, Wendy (2004) Neoliberalism in (regional) theory and practice: The Stronger Communities Action Fund. Research paper number 14. University of Auckland, Auckland.

Lamm, Richard D. (2001) The Ten Commandments of CommunityDiversity and Togetherness. Address 28.11.2000 delivered to the Morris summit, Morristown, New Jersey.

Latham, Mark (2001) The Third Way: An Outline. Chapter 1, The Global Third Way Debate edited by Anthony Giddens. Polity Press: Malden, Mass.

Laville, Jean-Louis et al (1999) Third System: A European Definition. European Commission.

Laville, Jean-Louis (2000) Tomorrow's Humane Economy. UNESCO Courier, Sep., Page 20.

Laville, Jean-Louis (2003) A new European socioeconomic perspective. Review of the Social Economy, September, v61 i3. 
Licensing Trusts case sources: Invercargill Licensing Trust Act 1944, Sale of Liquor Act 1989; Poll results from various returning officers.

Lind, Clive A. (1994) Pubs, Pints and People 50years of the Invercargill Licensing Trust. Craigs: Invercargill.

Lindsey, Brink (2002) Against the Dead Hand: The Uncertain Struggle for Global Capitalism. John Wiley: Washington DC.

Llosa, Mario Vargas, (2002) Liberalism in the New Millenium, in David Boaz (editor), Toward Liberty: The Idea that is Changing the World. Cato Institute: Washington.

Lloyd, John (2001) The Protest Ethic: How the Anti-globalization Movement Challenges Social Democracy. London: Demos.

Lomborg, Bjorn (2003) The Real State of the World. $9^{\text {th }}$ annual Sir Ronald Trotter Lecture on www.nzbr.org.nz.

McCann, Dennis P. (2000) Do

Corporations Have Any Responsibility Beyond Making a Profit? On web-site www.acton.org.

McCann, Dennis P. (2000) Do Corporations Have Any Responsibility Beyond Making a Profit. A Response to Norman P. Barry. Markets and Morality, Acton Institute, vol.3, no.1.

McCloskery D.N. (1985) The Rhetoric of Economics. University of Wisconsin Press: Madison.

McKinlay, Peter (2001) Public Wealth and Trusts. IPS policy paper,
Institute of Policy Studies: Victoria University, Wellington.

McKinlay, Peter (1999) Public

Ownership and the Community.

Institute of Policy Studies, Victoria University, Wellington.

Majone, G. (1989) Evidence, Argument, \& Persuasion in the Policy Process. Yale University Press: New Haven.

Manson, Kate and Hugo Manson (2001) Making a Difference A History of the Community Trust of Wellington. The Community Trust of Wellington.

Maslow, Abraham H. (1943) Preface to Motivation Theory.

Psychosomatic Medicine, 5, 8592.

Maslow, Abraham H. (1954) Motivation and Personality. Harper: New York.

Maslow, Abraham H. (1968) Toward a Psychology of Being. van Nostrand: Princeton, NJ.

Massaro, Thomas SJ (2000) Review of Bilgrien's book. Theological Studies. September 2000, v61.

Masterton Licensing Trust case references:

- Annual reports and accounts 1948-2004;

- Correspondence files located at Trust House Limited;

- Newspaper clipping files at Trust House Limited;

- A Matter of Trust: Masterton Licensing Trust 1947-1997;

- Hansard debates from volume 264 1944-1949; 
- Donations application form and explanatory notes;

- Licensing Trusts in New Zealand: a Unique Social Mandate. Masters thesis, Massey University (B.J.Teahan, 1990);

- Minutes of the Trust.

- Masterton Licensing Trust Act 1947.

Masterton Trust Lands Trust case references:

- Annual reports;

- Wairarapa Times-Age newspaper articles;

- Masterton Trust Lands Act 2003;

- Henderson, Alan as listed above.

Mathes, E. (1981) Maslow's Hierarchy of Needs as a Guide for Living. Journal of Humanistic Psychology, 21.

Maxwell, J. (1992) Understanding and Validity in Qualitative Research. Harvard Educational Review, 62.

Megginson, William L. and Jeffrey M.Netter (2001) From State to Market: A Survey of Empirical Studies on Privatization. Journal of Economic Literature, vol. 39, no. 2

Ministry of Commerce (1998) Electricity Information Disclosure Statistics 1998. Ministry of Commerce, Wellington.

Mitchell, Stacy (2002) An Interview with Stacy Mitchell. Multinational Monitor, Oct-Nov.
Murphey, Dwight D. (1999) Do Market Economies Allocate Resources Optimally? Markets and Morality, vol. 2, no. 2, Acton Institute.

Negandhi, Anant, Howard Thomas and William Emmons (1986) Comparing Public and Private Enterprises in an International Context: Some Hypotheses. Research in International Business and International Relations, vol. 1.

New Zealand Public Service Association (1989) SOE Privatisation: The Next Logical Step?

Nouwen, Henri J.M. (1976) Reaching Out. William Collins and Sons: Glasgow.

Novak, Michael (1991) The Spirit of Democratic Capitalism. Madison: Maryland.

Novak, Michael (1999) The Crisis of the Welfare State: Economics and Ethics. In Praise of the Free Economy. The Centre for Independent Studies, Sydney, NSW.

OECD (1999) Social Enterprises. Organisation for Economic Cooperation and Development.

Onwuebuzie, Anthony J. (2002) Why can't we all get along? Towards a framework for unifying research paradigms. Education, vol. 122, no.3, 518-530.

Passey, Andrew and Mark Lyons (2004) Government Initiatives to Develop the UK Social Economy. Accord paper No.12, University of Technology, Sydney. 
Paul VI, (1965) Pastoral Constitution of the Church in the Modern World. Gaudium et Spes.

Peredo, Ana Maria (2003) Emerging Strategies Against Poverty. The Road Less Traveled. Journal of Management Inquiry, Vol.12, no.2.

Peters, Michael and James Marshall (1988) Social Policy and the Move to Community, Report of the Royal Commission on Social Policy. Royal Commission on Social Policy; Mayfair House, Wellington.

Peters, Thomas J. and Robert H.Waterman (1982) In Search of Excellence. Harper\& Row: New York.

Pfeffer, Jeffrey (1998) The Human Equation. Harvard Business School Press: Boston, Mass.

Popper, K. (1959) The Logic of Scientific Discovery. London: Heinemann.

Porter, Michael E. and Mark R. Kramer (1999) Philanthropy's New Agenda: Creating Value. Harvard Business Review, November-December.

Porter, Michael E. and Mark R. Kramer (2002) The Competitive Advantage of Corporate Philanthropy. Harvard Business Review, December.

Portes, Allejandro and Patricia Landolt (1996) The Downside of Social Capital. The American Prospect, no.26, May-June.

Prescott-Allen, Robert (2001) The Wellbeing of Nations: a Country-byCountry Index of Quality of Life and the Environment. Island Press: CA, USA.
Price Waterhouse (1989)

Privatisation: Learning the Lessons from the UK Experience and Privatisation: The Facts. Price Waterhouse: London.

Putnam, Robert D. (2000) Bowling Alone. Simon\& Schuster: New York.

Roger, Warwick (1989) Places in the Heart. Century, Hutchinson: Auckland.

Ryan, Bill (2006) Examiner's comments on this thesis. Faculty of Commerce and Administration, Victoria University, Wellington, New Zealand.

Salamon, Lester M. and Helmut K. Anheir (1997) The civil society sector. Society, Jan-Feb, v34 n2.

Salamon, Lester M. (2003) Data released on Worldwide Nonprofit Sector: Johns Hopkins-led Effort Tracks 35 Countries. Ascribe Higher Education News Service, April 15. Also, Global Civil Society An Overview. With S. Wojciech Sokolowski and Regina List. The Johns Hopkins Comparative Nonprofit Sector Project. Johns Hopkins University Institute for Policy Studies Center for Civil Society Studies.

Sandel, Michael J. (1982) Liberalism and the Limits of Justice. Cambridge University Press: Cambridge.

Sanders, Peter and Nicole Billante (2002) Does Prison W ork? Policy: The Centre for Independent Studies: St. Leonards, NSW.

Schellenberg, Grant (2004) Perceptions of Canadians: $A$ sense of 
belonging, confidence and trust.

Statistics Canada- Cat. No.11008.

Schmidt, V.A. (2002) The Futures of European Capitalism. Oxford: Oxford University Press.

Scott, Graham (2002) Community Trusts in New Zealand. University of Otago: Dunedin.

Sechrest, Lee; Stewart, Michelle; Stickle, Timothy and Souraya Sidani (1996) Effective and Persuasive Case Studies. Evaluation Center@HSRI.

Seldon, Arthur (1990) Capitalism. Basil Blackwell: Oxford [England]; Cambridge, Mass.

Seldon, Arthur (1980) A Credo for Private Enterprise. New Zealand Employers Federation.

Sheen, Fulton J. (1955) Way to Happiness. Browne and Nolan, Dublin.

Shore, Bill (2001) The Cathedral Within. Random House: New York.

Shuman, Michael H. (2000) Going Local: Creating Self-reliant communities in a global age. Routledge: New York.

Solomon, Robert C. (1994) Above the Bottom Line: An Introduction to Business Ethics. Harcourt Brace College: Fort Worth, Tex.

Spicer, Barry; David Emmanuel and Michael Powell (1996)

Transforming Government Enterprises: Managing Radical Organisational Change in Deregulation Environments. Centre for Independent Studies, Wellington.
Stake, Robert E. (1995) The Art of Case Study Research. Sage: London.

Stiglitz, Joseph (2001) An Agenda for Development for the Twenty-First Century. Chapter 24, The Global Third Way Debate edited by Anthony Giddens. Polity Press: Malden, Mass.

Stiglitz, Joseph (2002) Globalization and its Discontents. W.W.Norton and Co.: New York.

Strike, Kenneth A. (1993) Community and Individualism: Two Views. Studies in Philosophy and Education, 12: 11-20.

TSB Community Trust (December, 2003) Strategic Plan produced and circulated by that Trust.

TSB Case Study references:

- Douglas, Roger and Louise Callen (1987) Towards Prosperity. Auckland: David Bateman.

- Eastern and Central Community Trust annual reports 1989-2004.

- Institute of Policy Studies (1988) State Owned Enterprises: Privatisation and Regulation-Issues and Options. Victoria University Press: Wellington.

- Jennings, Stephen and Rob Cameron (1987) State-Owned Enterprise Reform in New Zealand in Bollard, Allan and Robert Buckle (eds) Economic Liberalisation in New Zealand. Wellington: Allen and Unwin. 
- Manson, Kate and Hugo (2001) Making a Difference: A History of the Community Trust of Wellington. The Community Trust of Wellington.

- Moore and Barton (1935) Banking in New Zealand. NZ Bank Officers Guild, Wellington.

- Ogilvy, David (1983) Ogilvy on Advertising. Pan Books, London.

- Prescott-Allen (2001) The Wellbeing of Nations: $A$ Country-by-country Index of Quality of Life and the Environment. IDRC/ Island Press.

- Scott, Graham (2002) Community Trusts in NZ Looking Forward and Looking Back. A Report for the twelve Community Trusts.

- The Community Trusts Act 1999.

- The Community Trust of Wellington annual reports 1989-2004.

- Tripe, David (2004) New Zealand Banks in the September Quarter 2003. Refer web-site www.centre-bankingstudies.massey.ac.nz/mainh.htm.

- The Taranaki Daily News: articles on the 26,27 , b28 June 1986, 2.7.1986, 18.6.1993, 29.5.1999, 24.6.1999, 23.12.2000, 9 and 11.8.2001
- TSB Bank (undated publication, circa 1994) Your Kind of Bank.

- TSB Bank Annual Reports Various years but including 1995-2004.

- TSB Community Trust Annual Reports Various Years but including 2000-2004.

- TSB Community Trust (December 2003) Strategic Plan.

- Web-sites:

- $\quad$ www.business.auckland.ac.nz

- $\quad$ www.tsb.co.nz

- www.stats.govt.nz

- www.psis.co.nz

- $\quad$ www.newplymouthnz.com

- $\quad$ www.oag.govt.nz

- www.anz.com

- $\quad$ www.asbbank.co.nz

- $\quad$ www.bnz.co.nz

- www.kiwibank.co.nz

- www.nationalbank.co.nz

- www.rbnz.govt.nz

- www.wib.westpac.co.nz

- $\quad$ www.ecct.org.nz

- www.comtrustwn.co.nz

Tararua Foundation case references:

- Annual reports and accounts;

- Correspondence files at Trust House Limited;

- Newspaper clippings;

- Deed of Trust dated August 1985. 
Teahan, B.J. (1990) Licensing Trusts in New Zealand: A Unique Social Mandate. Masters Thesis, Massey University.

Teahan, B.J. (2000) Community Owned Trading Enterprises: Their Uniqueness and Performance. Masters thesis, Massey University.

Teahan, B.J. (2003) The Challenge of Philanthropy. Philanthropy News, Winter, vol.2, no.32.

Teahan, B.J. (2003) ...Where we Started... Address to the NZLTA Conference, Queenstown.

The Sale of Liquor in New Zealand Report of the Royal Commission of Inquiry (1974). Government Print: Wellington.

The Treasury (1987) Government Management: Brief to the Incoming Government. Vols. I \& II, Government Printer: Wellington.

Toulmin, S. (1990) Cosmopolis: The Hidden Agenda of Modernity. University of Chicago Press: Chicago.

Tunisian National Solidarity Bank web-site sources:

- http://www.2626.org/eng/financial.htm

- http://www.tunisaonline.com L

- http://tourismtunisa.com/

- http://cia.gov/cia/publication s/factbook/geos/ts.html

Van Gorp, B. (2001) The Implementation of Asylum Policy: Which frame dominates the debate? A paper presented at the European Consortium for
Political Research, Grenoble, France; April.

Vatican Council, the Second (1965) Dignitatis Humanae: Declaration on Religious Freedom.

Younkins, Edward J. (1999) Michael Novak's Portrait of Democratic Capitalism. Acton Institute, Vol. 2, no.1, Spring.

Younkins, Edward J. (2001) Morality and Character Development: The Roles of Capitalism, Commerce, and the Corporation. Acton Institute, Vol.4, no.1, Spring.

Walters, Lawrence C. and Ray R. Sudweeks (1996) Public Policy Analysis: the next generation of theory. The Journal of SocioEconomics, Winter.

Weber, Ron (2004) The rhetoric of Positivism versus Interpretivism: a personal view. MIS Quarterly, 28.1, piii(10).

Weigel, George (2000) The Moral Foundations of Freedom. Millennial Acton Lecture of the Centre for Independent Studies, Sydney.

West Auckland Case Study references:

- CDL Hotels Limited. Annual accounts and reports 2001 to 2003 .

- Dominion Breweries Limited, Annual Accounts and Reports, 1999 to 2003.

- Dormer, Alan, Alastair Sheriff and John Crookston. (Updated regularly). Sale of Liquor Act 1989. Thomson and Brooker. 
- Gambling Act 2003 and various Gaming papers. Refer Department of Internal Affairs, New Zealand website: http://www.dia.govt.nz

- Garson, (2001). Case study research in public administration and public policy. North Carolina State University.

- Letters to the Editor in the NZ Herald and Western Leader. Various dates in 2002 and to March 2003.

- Lion Nathan Limited, Annual Accounts and Reports, 1999 to 2003 .

- Masterton Licensing Trust, Annual Reports and Accounts, 1996 and1997.

- Newspaper Articles- numerous including:

- NZ Herald- 29.1.03 Battle of the West to heat up from today; 10.2.03 Westies shouldn't kill off their quaint golden egg; 26.2.03 Trusts toast success after poll; 28.2.03 Liquor 'wet' and 'dry' rub together like sandpaper

- National Business Review - 14.2.03 Trustees and teachers test law with politics in schools; 7.2.03 Trusts look shaky; 28.2.03 Supermarkets: We'll win the west in 2006

- NZ Herald and Western Leader newspaper advertisementsNumerous.

- NZ Herald Editorials. 17 February 2003 and 28 February 2003.
- Office of the Controller and Auditor-General. (Sep 2003). Local Government: Results of the 2001-02 Audits.

- Portage Licensing Trust, Annual accounts and Reports, 1999 to 2003.

- Press Releases:

- Independent Report Slates Licensing Trusts (released by Foodstuffs and Progressive Managing Directors). Undated, late January or early February 2003.

- Trusts denounce supermarket smear campaign. 2.2.03. Released by the Portage and Waitakere Licensing Trusts.

- Thank you West Auckland. 4.3.03. Released by the Portage and Waitakere Licensing Trusts.

- Restaurant Brands Limited. Annual accounts and reports 1999-2003.

- Southland Times Editorial. 21 May 2002.

- Tourism Holdings Limited. Annual Report 2004.

- The Sale of Liquor in New Zealand. (1986). Report of the Working Party on Liquor.

- UMR research. (2000-2003). Various reports prepared for the Portage and Waitakere Licensing Trusts including analysis of Focus Groups and telephone surveys. 
- Waitakere Licensing Trust, Annual Accounts and Reports, 1999 to 2003.

- West Auckland Trust Services.

(Undated, circa 2002).

Licensing Trusts Life Blood of

the West Auckland Community.

Whyte and Whyte (1988) Making

Mondragon. ILR Press: Ithaca,

New York.

Williamson, John (2003) as quoted on the Global Trade Negotiations

Home Page, Center for

International Development at

Harvard University on web-site

www.cid.harvard.edu.

Williamson, Kirsty (2006) Research in constructivist frameworks using

ethnographic techniques. Library Trends, 55.1:83(19).

Wolf, Martin (2004) Why

Globalization Works. Yale

University Press: New Haven

and London.

Yin, Robert K. (2003) Case Study

Research Design and Methods. Sage:

California.

Zeuli, Kimberley A. and Robert

Cropp (1980, $4^{\text {th }}$ edition)

Cooperatives: Principles and Practices

in the $21^{\text {st }}$ Century. University of

Wisconsin Center for

Cooperatives. 
